Nevada

Environmental

Restoration

Project

\title{
Corrective Action Decision Document/Closure Report for Corrective Action Unit 410: Waste Disposal Trenches, Tonopah Test Range, Nevada
}

Controlled Copy No::

Revision No.: 0

December 2003

Approved for public release; further dissemination unlimited.

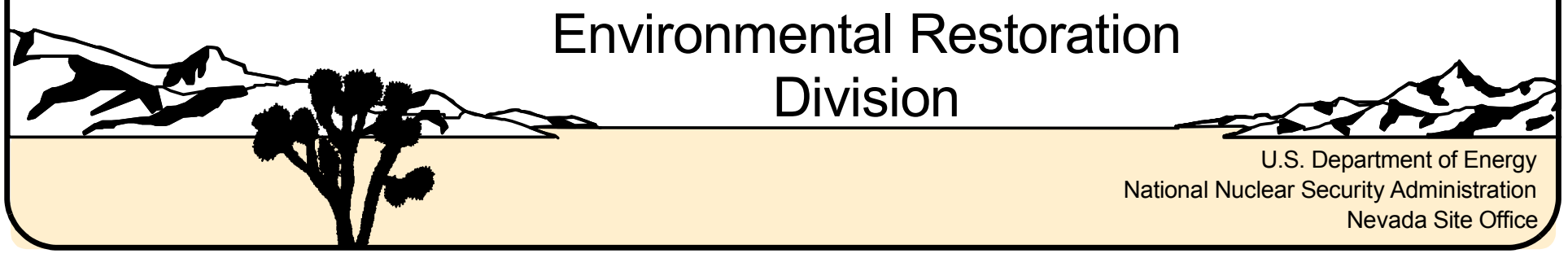


Available for public sale, in paper, from:

U.S. Department of Commerce

National Technical Information Service

5285 Port Royal Road

Springfield, VA 22161

Phone: 800.553 .6847

Fax: 703.605.6900

Email: orders@ntis.gov

Online ordering: http://www.ntis.gov/ordering.htm

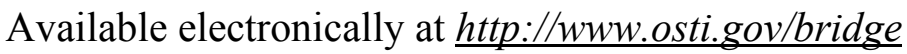

Available for a processing fee to U.S. Department of Energy and its contractors, in paper, from:

\section{U.S. Department of Energy}

Office of Scientific and Technical Information

P.O. Box 62

Oak Ridge, TN 37831-0062

Phone: 865.576 .8401

Fax: 865.576.5728

Email: reports@adonis.osti.gov

Reference herein to any specific commercial product, process, or service by trade name, trademark, manufacturer, or otherwise, does not necessarily constitute or imply its endorsement, recommendation, or favoring by the United States Government or any agency thereof or its contractors or subcontractors. 


\title{
CORRECTIVE ACTION DECISION DOCUMENT/CLOSURE REPORT FOR CORRECTIVE ACTION UNIT 410: WASTE DISPOSAL TRENCHES, TONOPAH TEST RANGE, NEVADA
}

\author{
U.S. Department of Energy \\ National Nuclear Security Administration \\ Nevada Site Office \\ Las Vegas, Nevada
}

Controlled Copy No.:

Revision No.: 0

December 2003

Approved for public release; further dissemination unlimited. 


\section{CORRECTIVE ACTION DECISION DOCUMENT/CLOSURE REPORT FOR CORRECTIVE ACTION UNIT 410: WASTE DISPOSAL TRENCHES, TONOPAH TEST RANGE, NEVADA}

Approved by: Signature Approved

Date: $12 / 16 / 03$

Janet Appenzeller-Wing, Project Manager

Industrial Sites Project

Approved by: Signature Approved

Date: $12 / 16 / 03$

Runore C. Wycoff, Division Director

Environmental Restoration Division 


\section{Table of Contents}

List of Figures. . . . . . . . . . . . . . . . .

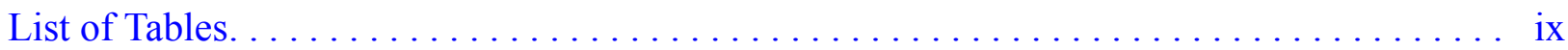

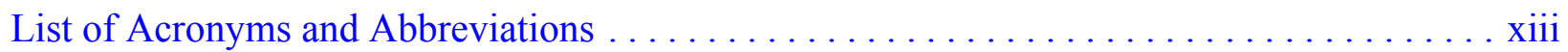

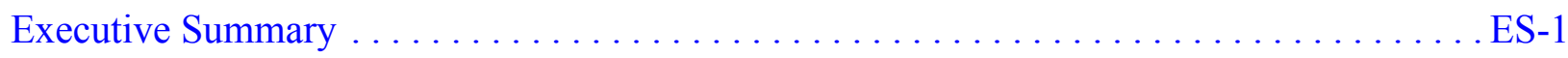

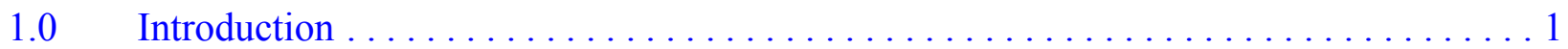

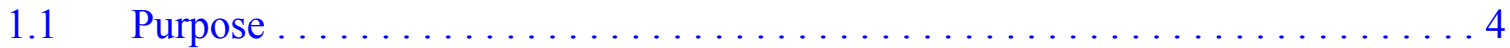

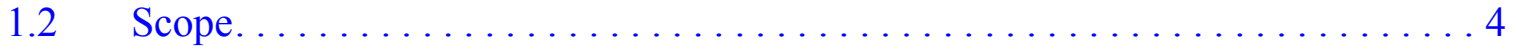

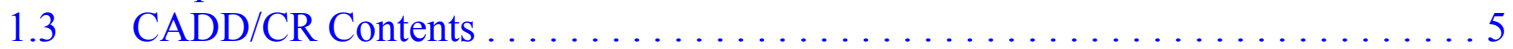

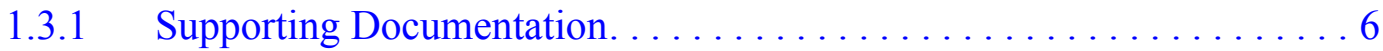

1.3.2 Data Quality Objectives ....................... 7

$2.0 \quad$ Corrective Action Investigation Summary $\ldots \ldots \ldots \ldots \ldots \ldots \ldots \ldots \ldots \ldots \ldots \ldots \ldots \ldots$

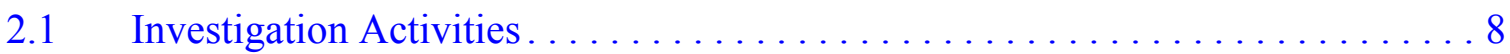

2.1.1 CAS TA-21-003-TANL, Disposal Trench.................. 9

2.1.2 CAS 09-21-001-TA09, Disposal Trenches .................. 9

2.1.3 CAS TA-19-002-TAB2, Debris Mound (Bunker Site) ............. 9

2.1.4 CAS TA-21-002-TAAL, Disposal Trench (Antelope Lake) . . . . . . . 11

2.1.5 CAS 03-19-001, Waste Disposal Site .................... 13

$2.2 \quad$ Results ........................................ 14

2.2.1 Summary of Analytical Data ..................... 14

2.2.1.1 CAS TA-21-003-TANL, Disposal Trench ........... 15

2.2.1.2 CAS 09-21-001-TA09, Disposal Trench ............ 15

2.2.1.3 CAS TA-19-002-TAB2, Debris Mound ............ 15

2.2.1.4 CAS TA-21-002-TAAL, Disposal Trench ............ 16

2.2.1.5 CAS 03-19-001, Waste Disposal Site . ............ 17

2.2.2 Summary of Data Assessment . . . . . . . . . . . . . . . . . . . 17

$2.3 \quad$ Justification for No Further Action. . . . . . . . . . . . . . . . . . . . . . 18

3.0 Recommendations....................................... 22

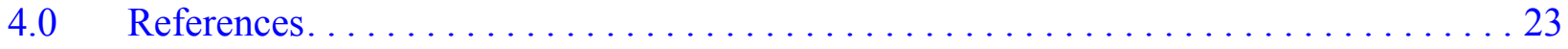

\section{Appendix A - Corrective Action Investigation Results for CAU 410: Waste Disposal Trenches Tonopah Test Range, Nevada}

A.1.0 Introduction. . . . . . . . . . . . . . . . . . . . .

A.1.1 Project Objectives. . . . . . . . . . . . . . . . . . . . . . . . . . A-1

A.1.2 Report Content .................................. A

A.2.0 Investigation Overview. . . . . . . . . . . . . . . . . . . $\ldots \ldots \ldots$ A 


\section{Table of Contents (Continued)}

A.2.1 Deviations ..................................... A

A.2.2 Preliminary Conceptual Model. ........................ A-4

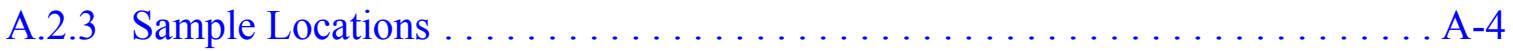

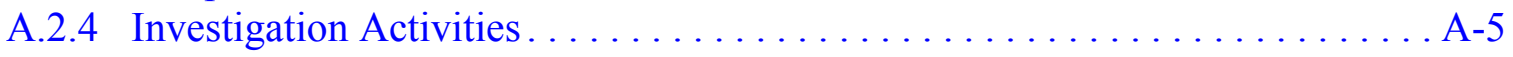

A.2.4.1 Field Screening............................. A-5

A.2.4.2 Intrusive Investigation Activities . . . . . . . . . . . . . . . A-5

A.2.5 Waste Characterization Sampling. . . . . . . . . . . . .

A.2.6 Laboratory Analytical Information. . . . . . . . . . . . . . . . . A

A.2.7 Comparison to PALs. . . . . . . . . . . . . . . . . . . . . . . . . . A-8

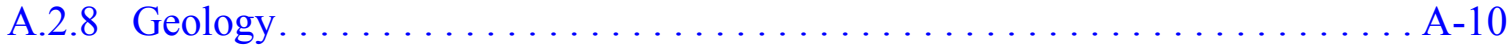

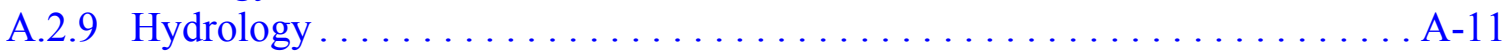

A.3.0 CAS TA-21-003-TANL, Disposal Trench ..................... A-12

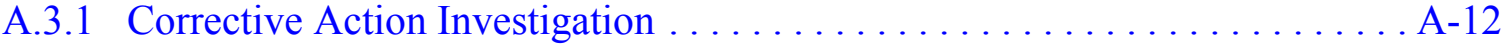

A.3.1.1 CAIP Implementation. . . . . . . . . . . . . . . . . . . . A-13

A.3.1.2 Deviations.............................. A-13

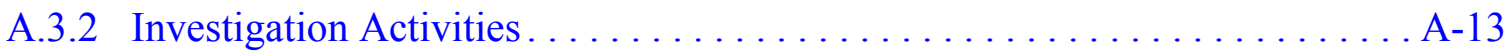

A.3.2.1 Field Screening............................... A-13

A.3.2.2 Excavation ................................ A 13

A.3.2.3 Waste Characterization. ...................... A-15

A.3.2.4 Sample Analysis............................... A-15

A.3.3 Analytes Detected Above MRL $\ldots \ldots \ldots \ldots \ldots \ldots \ldots \ldots \ldots \ldots \ldots$. $\ldots$.15

A.3.3.1 Total RCRA Metals Results . . . . . . . . . . . . . . . . . A-15

A.3.3.2 Isotopic Uranium Results . . . . . . . . . . . . . . . A-16

A.3.3.3 Gamma-Emitting Radionuclides Results ............... A-17

A.3.4 Contaminants of Concern ............................. A-17

A.3.5 Nature and Extent of Contamination $\ldots \ldots \ldots \ldots \ldots \ldots \ldots \ldots \ldots \ldots$ A -17

A.3.6 Revised Conceptual Site Model . . . . . . . . . . . . . . . . . . A-17

A.4.0 CAS 09-21-001-TA09, Disposal Trenches........................ A-19

A.4.1 Corrective Action Investigation . . . . . . . . . . . . . . . . . A-19

A.4.2 CAIP Implementation. . . . . . . . . . . . . . . . . $\ldots \ldots \ldots$

A.4.2.1 Deviations............................ A-20

A.4.3 Investigation Activities............................. A-20

A.4.3.1 Field Screening. ........................... A-20

A.4.3.2 Excavation ............................. A-20

A.4.3.3 Sample Collection ......................... A-20

A.4.3.4 Waste Characterization......................... A-22

A.4.3.5 Sample Analysis........................... A-22

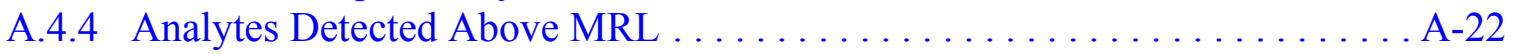

A.4.4.1 Total RCRA Metals Results.................... A-22 


\section{Table of Contents (Continued)}

A.4.4.2 Gamma-Emitting Radionuclides Results . . . . . . . . . . . A-23

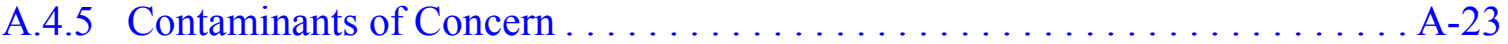

A.4.6 Nature and Extent of Contamination . . . . . . . . . . . . . . . A-23

A.4.7 Revised Conceptual Site Model . . . . . . . . . . . . . . . . A-23

A.5.0 CAS TA-19-002-TAB2, Debris Mound (Bunker 2 Site) . . . . . . . . . . . . . . . A-25

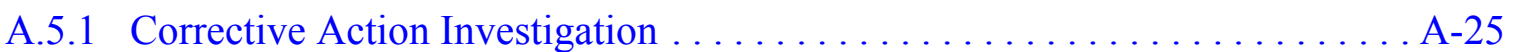

A.5.2 CAIP Implementation. . . . . . . . . . . . . . . . . . . . $\ldots \ldots$

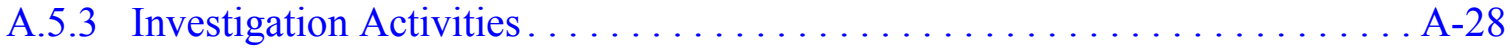

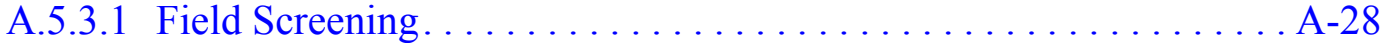

A.5.3.2 Excavation . . . . . . . . . . . . . . . . . A-29

A.5.3.3 Waste Characterization. ....................... A-33

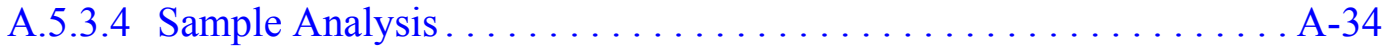

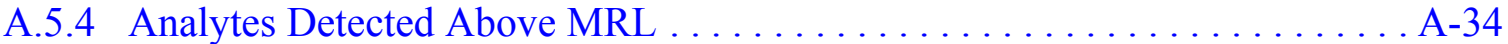

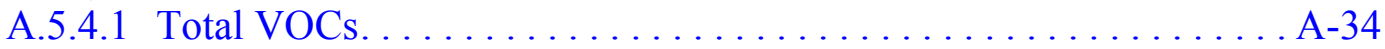

A.5.4.2 Total Metals . . . . . . . . . . . . . . . . . . . . . . A-35

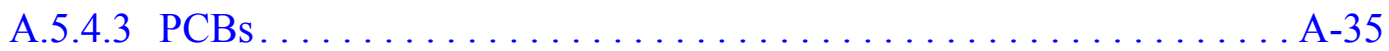

A.5.4.4 Isotopic Uranium . . . . . . . . . . . . . . . . A-36

A.5.4.5 Gamma-Emitting Radionuclides . . . . . . . . . . . A-38

A.5.5 Contaminants of Concern . . . . . . . . . . . . . . . . . . A A-41

A.5.6 Nature and Extent of Contamination . . . . . . . . . . . . . . A-41

A.5.7 Revised Conceptual Site Model . . . . . . . . . . . . . . . . . . . . . . . . . . A-41

A.6.0 CAS TA-21-002-TAAL, Disposal Trench (Antelope Lake) . . . . . . . . . . . . . . A-42

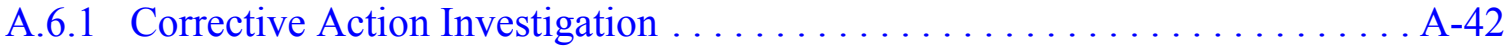

A.6.2 CAIP Implementation . . . . . . . . . . . . . . . . . . . . A-42

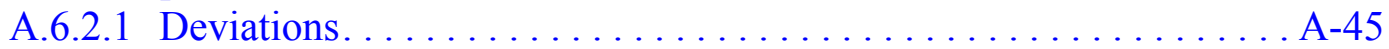

A.6.3 Investigation Activities . . . . . . . . . . . . . . . . . A $\ldots \ldots$

A.6.3.1 Field Screening. . . . . . . . . . . . . . . . . A-46

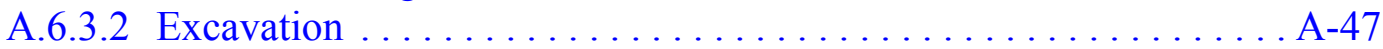

A.6.3.3 Waste Characterization. . . . . . . . . . . . . . . . A-50

A.6.3.4 Sample Analysis... . . . . . . . . . . . . . . . . . A-51

A.6.4 Analytes Detected Above MRL . . . . . . . . . . . . . . . . A

A.6.4.1 Total VOCs. . . . . . . . . . . . . . . . . . . . . A-52

A.6.4.2 Total Metals ............................ A-52

A.6.4.3 Isotopic Uranium Results . . . . . . . . . . . . . . . . . . A-53

A.6.4.4 Gamma-Emitting Radionuclides Results ................ A-53

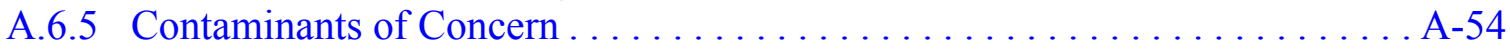

A.6.6 Nature and Extent of Contamination . . . . . . . . . . . . . . . A A-56

A.6.7 Revised Conceptual Site Model . . . . . . . . . . . . . . . . . A-56 


\section{Table of Contents (Continued)}

A.7.0 CAS 03-19-001, Waste Disposal Site.......................... A-59

A.7.1 Corrective Action Investigation . . . . . . . . . . . . . . . . A-59

A.7.2 CAIP Implementation. . . . . . . . . . . . . . . . . . . . A 59

A.7.2.1 Deviations............................. A-63

A.7.3 Investigation Activities . . . . . . . . . . . . . . . . . . . . A-63

A.7.3.1 Field Screening. . . . . . . . . . . . . . . . . . . . . . A-64

A.7.3.2 Excavation ................................ A 64

A.7.3.3 Hollow-Stem Auger Drilling ...................... A-68

A.7.3.4 Waste Characterization. . . . . . . . . . . . . . . . . . . A-72

A.7.3.5 Sample Analysis............................ A-72

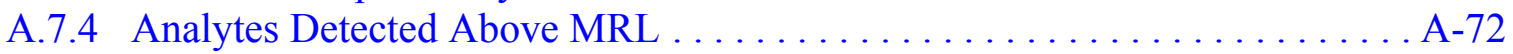

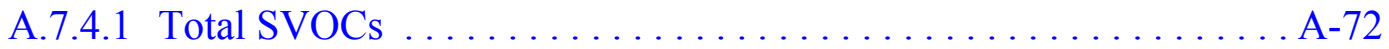

A.7.4.2 Total Metals . . . . . . . . . . . . . . . . . . . . . . . . .

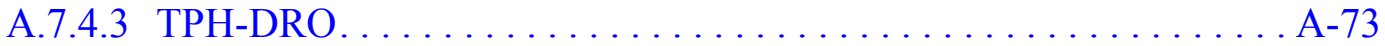

A.7.4.4 PCBs...................................

A.7.4.5 Pesticides ................................ A-77

A.7.4.6 Isotopic Uranium . . . . . . . . . . . . . . . . . . . . . A-77

A.7.4.7 Gamma-Emitting Radionuclides ................... A-77

A.7.5 Contaminants of Concern ......................... A

A.7.6 Nature and Extent of Contamination $\ldots \ldots \ldots \ldots \ldots \ldots \ldots \ldots \ldots \ldots \ldots \ldots \ldots$

A.7.7 Revised Conceptual Site Model . . . . . . . . . . . . . . . . . . . . A-81

A.8.0 Quality Assurance . . . . . . . . . . . . . . . . . . . . . . . . . . . . A-82

A.8.1 Data Validation............................... A-82

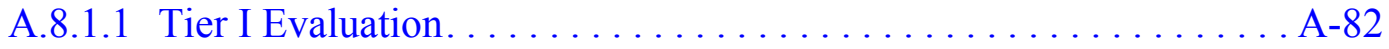

A.8.1.2 Tier II Evaluation . . . . . . . . . . . . . . . . . . . . A-83

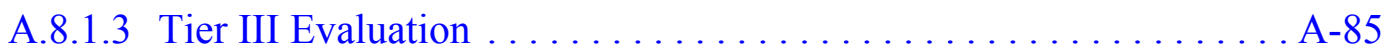

A.8.2 Quality Control Samples........................... A-85

A.8.2.1 Field Quality Control Samples.................... A-86

A.8.2.2 Laboratory Quality Control Samples ................. A-86

A.8.3 Field Nonconformances . . . . . . . . . . . . . . . . . . . . A 86

A.8.4 Laboratory Nonconformances $\ldots \ldots \ldots \ldots \ldots \ldots \ldots \ldots \ldots \ldots \ldots \ldots \ldots \ldots \ldots \ldots$

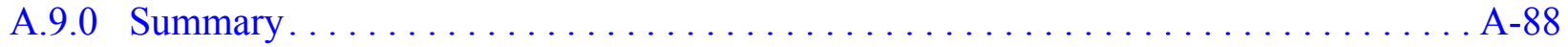

A.10.0 References. ....................................... A-89

\section{Appendix B - Data Assessment for CAU 410}

B.1.0 Data Assessment. . . . . . . . . . . . . . . . . . . . . . . . . . . . . . . . . . B-1

B.1.1 Statement of Acceptability and Usability . . . . . . . . . . . . . . B-1 


\section{Table of Contents (Continued)}

B.1.1.1 Precision ...................................

B.1.1.1.1 Precision for Chemical Analyses .............. B-2

B.1.1.1.2 Precision for Radiological Analysis $\ldots \ldots \ldots \ldots \ldots$. . . . 6

B.1.1.1.3 Precision Summary $\ldots \ldots \ldots \ldots \ldots \ldots \ldots \ldots \ldots$ B-8

B.1.1.2 Accuracy.............................

B.1.1.2.1 Accuracy for Chemical Analyses . . . . . . . . . . . . . B-9

B.1.1.2.2 Accuracy for Radiological Analyses . . . . . . . . . . B-12

B.1.1.2.3 Accuracy Summary . . . . . . . . . . . . . . . B-13

B.1.1.3 Completeness ............................ B-14

B.1.1.3.1 Rejected Data ........................ B-16

B.1.1.4 Representativeness . . . . . . . . . . . . . . . . . . . . . . . . . B-16

B.1.1.5 Comparability............................. B-16

B.1.2 Reconciliation of DQOs to Conceptual Site Model .................. B-19

B.1.2.1 Initial Conceptual Site Models...................... B-19

B.1.2.2 Investigation Design and Contaminant Identification ........... B-19

B.1.2.3 Contaminant Nature and Extent . . . . . . . . . . . . . B-20

B.1.3 Conclusions....................................

B.2.0 References......................................

\section{Appendix C - Risk Assessment}

C.1.0 Risk Assessment . .................................... C-1

\section{Appendix D - Closure Activities and Waste Disposition for CAU 410}

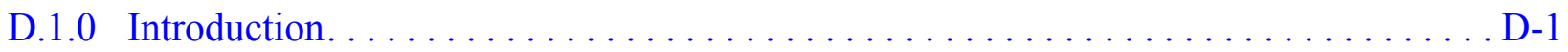

D.2.0 Closure Activities ................................... D-2

D.2.1 CAS TA-21-003-TANL and CAS 09-21-001-TA09,

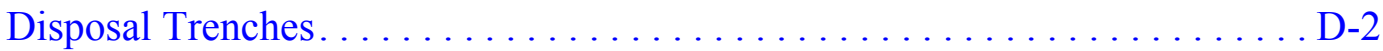

D.2.2 CAS TA-19-002-TAB2, Debris Mound ....................

D.2.3 CAS TA-21-002-TAAL, Disposal Trench . . . . . . . . . . . . . . . D-3

D.2.4 CAS 03-19-001, Waste Disposal Site..................... D-6

D.3.0 Waste Management. .................................... D

D.3.1 Waste Minimization ................................ D

D.3.2 Waste Characterization................................ D

D.3.2.1 Waste Streams ............................. D-10

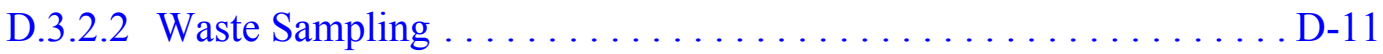

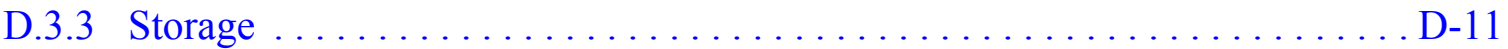

D.3.4 Waste Disposal .................................. 


\section{Table of Contents (Continued)}

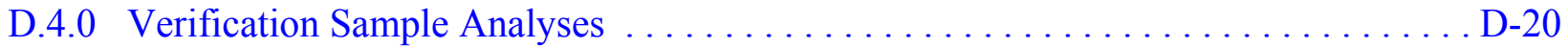

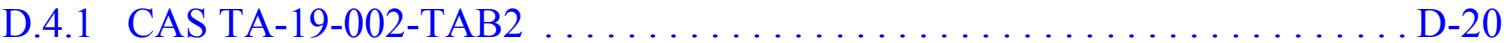

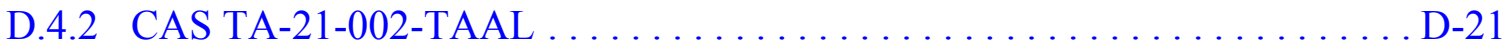

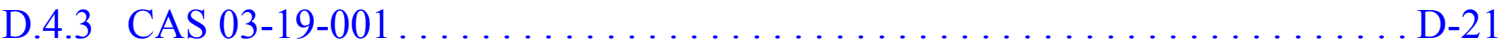

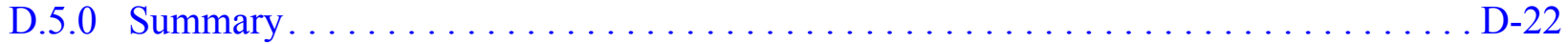

Appendix E - Waste Manifests for CAU 410

Appendix F - Nevada Division of Environmental Protection Comment Responses 


\section{List of Figures}

Number

Title

Page

1-1 Tonopah Test Range Location Map ............................

1-2 TTR CAU 410 CAS Location Map ............................. 3

A.3-1 CAU 410, CAS TA-21-003-TANL, Soil Sample Locations . . . . . . . . . . . . A-14

A.4-1 CAU 410, CAS 09-21-001-TA09, Soil Sampling Locations.............. A-21

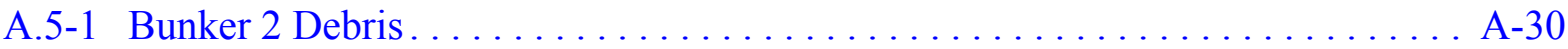

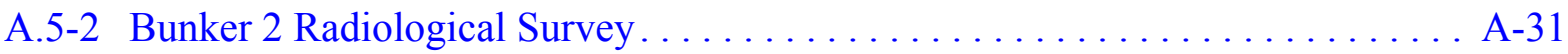

A.5-3 CAU 410, CAS TA-19-002-TAB2, Soil Sampling Locations . . . . . . . . . A-32

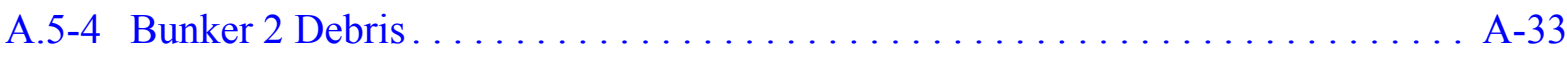

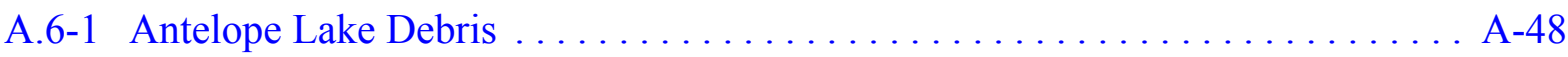

A.6-2 CAU 410, CAS TA-21-002-TAAL, Soil Sampling Locations . . . . . . . . . . . A-49

A.6-3 Antelope Lake Excavation. . . . . . . . . . . . . . . . . . .

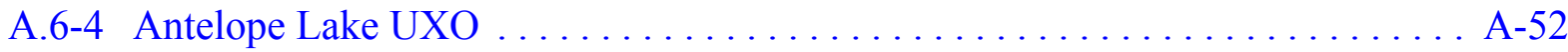

A.7-1 Sample Location Map for Initial Investigation of CAS 03-19-001 . . . . . . . . A-66

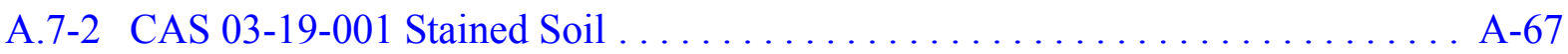

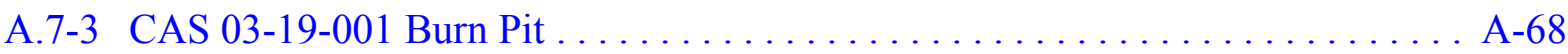

A.7-4 CAS 03-19-001 TPH Area. . . . . . . . . . . . . . . . . . . . A-69

A.7-5 General Site Layout and Sample Location Map after Supplemental

Field Activities, CAS $03-19-001 \ldots \ldots \ldots \ldots \ldots \ldots \ldots \ldots \ldots \ldots \ldots \ldots \ldots$ 


\section{List of Figures (Continued)}

Number

A.7-6 Detailed Sketch of TPH Confirmation Sample Locations, CAS 03-19-001 . . . . A-71

D.2-1 DU-Waste Containers at Bunker $2 \ldots \ldots \ldots \ldots \ldots \ldots \ldots \ldots \ldots \ldots \ldots \ldots \ldots \ldots \ldots \ldots$

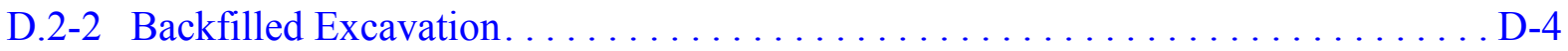

D.2-3 Backfilled Excavation.................................. D-5

D.2-4 Waste Hauling. . . . . . . . . . . . . .

D.2-5 Backfilled Excavation. ................................. D-7

D.2-6 CAS 03-19-001 Closure ................................ D-8

D.3-1 UXO Demilitarization Activities at Antelope Lake ................. D-16

D.3-2 UXO Demilitarization Activities at Antelope Lake ................ D-17

D.3-3 Demilitarization of DU-Contaminated UXO at Antelope Lake ............. . D-18

D.3-4 Inert UXO Transported to Recycle Pile on Range .................. D-19 


\section{List of Tables}

Number

Title

Page

1-1 CAU 410 Corrective Action Sites and Associated Facilities $\ldots \ldots \ldots \ldots \ldots \ldots$

A.2-1 Laboratory Analytical Parameters and Methods, CAU 410 Samples . . . . . . . . . A-7

A.3-1 Samples Collected for CAS TA-21-003-TANL, Disposal Trench . . . . . . . . . A-12

A.3-2 Soil Sample Results for Total RCRA Metals Detected Above Minimum

Reporting Limits at CAS TA-21-003-TANL . . . . . . . . . . . A-16

A.3-3 Soil Sample Results for Isotopic Uranium Detected Above Minimum

Reporting Limits at CAS TA-21-003-TANL . . . . . . . . . . . A-16

A.3-4 Soil Sample Results for Gamma-Emitting Radionuclides Detected Above

Minimum Reporting Limits at CAS TA-21-003-TANL . . . . . . . . . . . . A-18

A.4-1 Samples Collected for CAS 09-21-001-TA09, Disposal Trenches . . . . . . . . . A-19

A.4-2 Soil Sample Results for Total RCRA Metals Detected Above Minimum

Reporting Limits at CAS 09-21-001-TA09.................. A-22

A.4-3 Soil Sample Results for Gamma-Emitting Radionuclides Detected Above Minimum Reporting Limits at CAS 09-21-001-TA09 . . . . . . . . . . . . A-24

A.5-1 Samples Collected for CAS TA-19-002-TAB2, Debris Mound . . . . . . . . . A-26

A.5-2 Summary of Excavation Activities at CAS TA-19-002-TAB2 . . . . . . . A A-28

A.5-3 Soil Sample Results for Total VOCs Detected Above Minimum Reporting Limits at CAS TA-19-002-TAB2 . . . . . . . . . . . . . . A-34

A.5-4 Soil Sample Results for Metals Detected Above Minimum Reporting Limits at CAS TA-19-002-TAB2 . . . . . . . . . . . . . . A-35 


\section{List of Tables (Continued)}

Number

Title

Page

A.5-5 Soil Sample Results for PCBs Detected Above Minimum Reporting

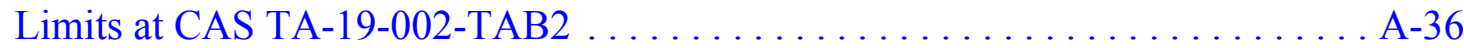

A.5-6 Soil Sample Results for Isotopic Uranium Detected Above Minimum

Reporting Limits at CAS TA-19-002-TAB2 . . . . . . . . . . . . A-37

A.5-7 Solid Sample Results Detected Above Minimum Reporting Limits at

CAS TA-19-002-TAB2

A.5-8 Soil Sample Results for Gamma-Emitting Radionuclides Detected Above

Minimum Reporting Limits at CAS TA-19-002-TAB2 . . . . . . . . . . . . . . A-39

A.6-1 Samples Collected for CAS TA-21-002-TAAL, Disposal Trench . . . . . . . . A A-43

A.6-2 Summary of Excavation Activities at CAS TA-21-002-TAAL . . . . . . . . . A-46

A.6-3 Soil Sample Results for Total VOCs Detected Above Minimum

Reporting Limits at CAS TA-21-002-TAAL . . . . . . . . . . . . . . A-53

A.6-4 Soil Sample Results for Total Metals Detected Above Minimum

Reporting Limits at CAS TA-21-002-TAAL . . . . . . . . . . . . . A-54

A.6-5 Soil Sample Results for Isotopes Detected Above Minimum Reporting

Limits at CAS TA-21-002-TAAL . . . . . . . . . . . . . A-55

A.6-6 Soil Sample Results for Gamma-Emitting Radionuclides Detected Above

Minimum Reporting Limits at CAS TA-21-002-TAAL . . . . . . . . . . . . A-57

A.7-1 Samples Collected for CAS 03-19-001, Waste Disposal Site . . . . . . . . . . A-60

A.7-2 Summary of Excavation Activities at CAS $03-19-001 \ldots \ldots \ldots \ldots \ldots \ldots$. . . . . . . .

A.7-3 Soil Sample Results for Total SVOCs Detected Above Minimum

Reporting Limits at CAS $03-19-001 \ldots \ldots \ldots \ldots \ldots \ldots \ldots \ldots \ldots \ldots \ldots$ 


\section{List of Tables (Continued)}

Number

Title

Page

A.7-4 Soil Sample Results for Metals Detected Above Minimum Reporting Limits at CAS $03-19-001 \ldots \ldots \ldots \ldots \ldots \ldots \ldots \ldots \ldots \ldots \ldots$. . . . . . . . . . . . . . . . . . . . .

A.7-5 Soil Sample Results for TPH-DRO Detected Above Minimum Reporting

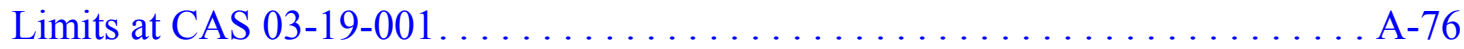

A.7-6 Soil Sample Results for PCBs Detected Above Minimum Reporting

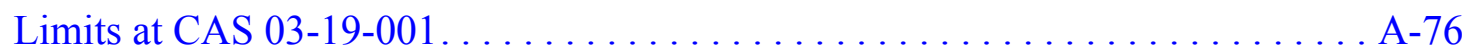

A.7-7 Soil Sample Results for Pesticides Detected Above Minimum Reporting Limits at CAS $03-19-001 \ldots \ldots \ldots \ldots \ldots \ldots \ldots \ldots \ldots \ldots \ldots$. . . . . . . . . . . . . . .

A.7-8 Soil Sample Results for Isotopic Uranium Detected Above Minimum

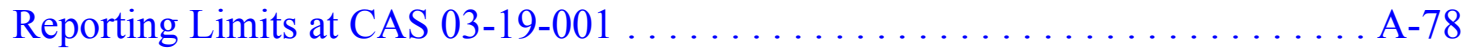

A.7-9 Soil Sample Results for Gamma-Emitting Radionuclides Detected Above Minimum Reporting Limits at CAS 03-19-001 . . . . . . . . . . . . . . . A-79

B.1-1 Chemical Precision Measurements for CAU $410 \ldots \ldots \ldots \ldots \ldots \ldots \ldots$. $\ldots \ldots$

B.1-2 Laboratory Duplicate Precision for Radioanalytes $\ldots \ldots \ldots \ldots \ldots \ldots \ldots \ldots$. . . . . . .

B.1-3 Laboratory Matrix Spike/Matrix Spike Duplicate Precision for Radioanalytes ... . B-7

B.1-4 Field Duplicate Precision for Radioanalytes . . . . . . . . . . . . . . . B-8

B.1-5 Laboratory Accuracy Measurements for CAU $410 \ldots \ldots \ldots \ldots \ldots \ldots \ldots$. . . . .

B.1-6 Radioanalytical Laboratory Control Sample (LCS) Accuracy . . . . . . . . . . . . B-13

B.1-7 Radioanalytical Matrix Spike (MS) Accuracy. . . . . . . . . . . . . B-13

B.1-8 Chemical Completeness for CAU $410 \ldots \ldots \ldots \ldots \ldots \ldots \ldots \ldots \ldots \ldots \ldots \ldots \ldots \ldots$ 


\section{List of Tables (Continued)}

Number

B.1-9 Radiological Completeness for CAU $410 \ldots \ldots \ldots \ldots \ldots \ldots \ldots \ldots \ldots$ B-16

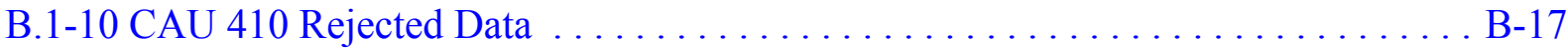

D.3-1 Solid Waste Disposal. ................................... D-14

D.3-2 UXO Demilitarization Activities for CAU $410 \ldots \ldots \ldots \ldots \ldots \ldots \ldots \ldots \ldots$. 15

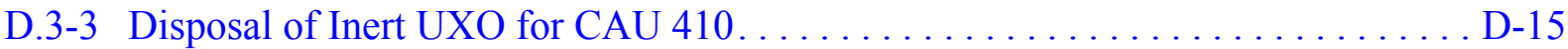




\section{List of Acronyms and Abbreviations}

bgs Below ground surface

BMP Best management practice

CADD Corrective Action Decision Document

CAI Corrective Action Investigation

CAIP Corrective Action Investigation Plan

CAS Corrective Action Site

CAU Corrective Action Unit

CFR Code of Federal Regulations

CLP Contract Laboratory Program

COC Contaminant of concern

COPC Contaminant of potential concern

CR Closure Report

CRDL Contract-required detection limit

CSM Conceptual site model

DOE U.S. Department of Energy

DOT U.S. Department of Transportation

DQO Data quality objective

DQI Data quality indicators

DRO Diesel-range organics

DU Depleted uranium

EOD Explosives ordnance disposal

EPA U.S. Environmental Protection Agency

EZ Exclusion Zone

FADL Field Activity Daily Log

FD Field duplicate

FFACO Federal Facility Agreement and Consent Order 


\section{List of Acronyms and Abbreviations (Continued)}

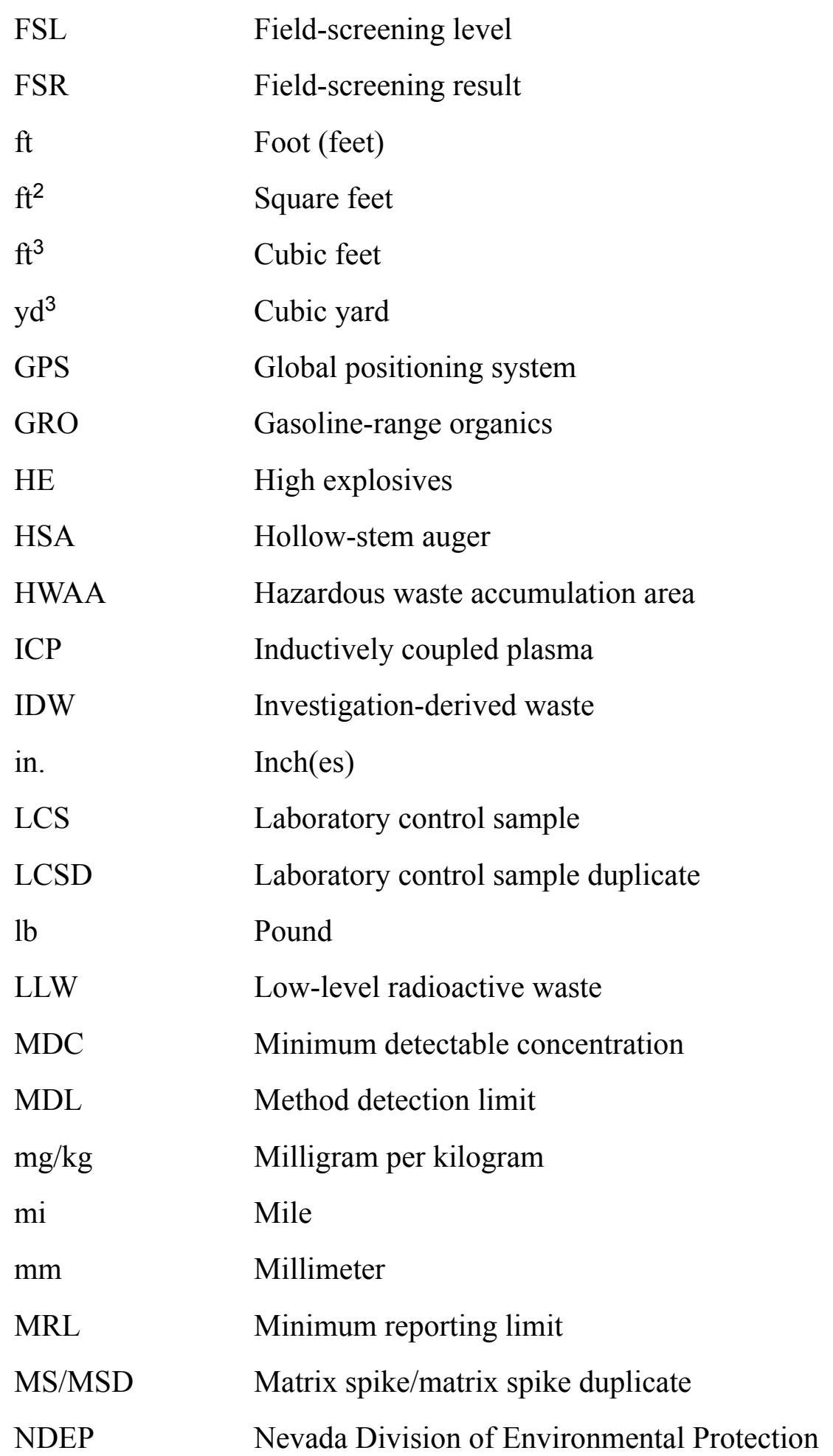




\section{List of Acronyms and Abbreviations (Continued)}

\begin{tabular}{|c|c|}
\hline NEDS & Non-violent Explosive Destruct System \\
\hline NIST & National Institute for Standards and Technology \\
\hline NNSA/NSO & $\begin{array}{l}\text { U.S. Department of Energy, National Nuclear Security Administration } \\
\text { Nevada Site Office }\end{array}$ \\
\hline NTS & Nevada Test Site \\
\hline NTSWAC & Nevada Test Site Waste Acceptance Criteria \\
\hline PAL & Preliminary action level \\
\hline $\mathrm{PB}$ & Preparation \\
\hline PCB & Polychlorinated biphenyls \\
\hline $\mathrm{pCi} / \mathrm{g}$ & Picocurie per gram \\
\hline PID & Photoionization detector \\
\hline PPE & Personal protective equipment \\
\hline ppm & Part per million \\
\hline PRG & Preliminary Remediation Goals \\
\hline $\mathrm{Pu}$ & Plutonium \\
\hline QA & Quality assurance \\
\hline QAPP & Quality Assurance Project Plan \\
\hline QC & Quality control \\
\hline $\mathrm{RCA}$ & Radiological Contamination Area \\
\hline RCRA & Resource Conservation and Recovery Act \\
\hline RDX & Royal Demolition Explosive \\
\hline RMA & Radioactive Materials Area \\
\hline ROTC & Record of Technical Change \\
\hline RPD & Relative percent difference \\
\hline RWMS & Radioactive Waste Management Site \\
\hline SAA & Satellite Accumulation Area \\
\hline SDG & Sample delivery group \\
\hline
\end{tabular}




\section{List of Acronyms and Abbreviations (Continued)}

Shaw

SNL/NM

SVOC

$\mathrm{TPH}$

TPU

TSCA

TTR

$\mathrm{U}$

USAF

UXO

VOC

WM

$\% \mathrm{R}$

$\mu \mathrm{g} / \mathrm{kg}$
Shaw Environmental and Infrastructure, Inc.

Sandia National Laboratories

Semivolatile organic compound

Total petroleum hydrocarbons

Total propagated uncertainties

Toxic Substance Control Act

Tonopah Test Range

Uranium

U.S. Air Force

Unexploded ordnance

Volatile organic compound

Waste Management

Percent recovery

Micrograms per kilograms 


\section{Executive Summary}

This Corrective Action Decision Document/Closure Report (CADD/CR) presents information supporting the recommendation of no further action for Corrective Action Unit (CAU) 410: Waste Disposal Trenches, Tonopah Test Range (TTR), Nevada. This CADD/CR complies with the requirements of the Federal Facility Agreement and Consent Order (1996) that was agreed to by the State of Nevada, the U.S. Department of Energy, and the U.S. Department of Defense. Corrective Action Unit 410 is located at the TTR, which is included in the Nevada Test and Training Range (formerly called the Nellis Air Force Range), and is approximately 235 miles northwest of Las Vegas, Nevada.

Corrective Action Unit 410 is located in Area 3, Area 9, south Antelope Lake, and the northern area of the Nonviolent Explosive Destruct System (NEDS) Lake of the TTR. The five Corrective Action Sites (CASs) that comprise CAU 410 are as follows:

- TA-21-003-TANL, Disposal Trench

- 09-21-001-TA09, Disposal Trenches

- TA-19-002-TAB2, Debris Mound

- TA-21-002-TAAL, Disposal Trench

- 03-19-001, Waste Disposal Site

From October 29 through November 7, 2002, initial investigation activities were conducted on all five CASs. Supplemental field activities were conducted March 3 through October 22, 2003, on CASs TA-19-002-TAB2, TA-21-002-TAAL, and 03-19-001. Corrective action investigation activities were performed as set forth in the Corrective Action Investigation Plan for Corrective Action Unit 410: Waste Disposal Trenches, Tonopah Test Range, Nevada (NNSA/NV, 2002a), and ROTCs No. 1 through No. 4. The purposes of the activities as defined during the data quality objectives process were:

- Determine if contaminants of concern (COCs) are present.

- If COCs are present, determine their nature and extent.

- Provide sufficient information and data to complete appropriate corrective actions for the CASs. 
Analytes detected during the corrective action investigation activities were evaluated against preliminary action levels (PALs) to determine the COCs for CAU 410. Assessment of the data generated from these activities indicate the PALs were exceeded for isotopic uranium at CASs TA-19-002-TAB2 and TA-21-002-TAAL and total petroleum hydrocarbons at CAS 03-19-001. However, the nature of the supplemental field investigation on these three CASs (i.e., excavation, segregation, and separation of soil, debris, and/or unexploded ordnance [UXO] to determine nature and extent) resulted in each CAS being free of contamination greater than PALs (based on verification samples) and free of waste/debris and UXO after the characterization activities. Initial investigation results for the remaining two CASs (TA-21-002-TANL and 09-21-001-TA09) indicate no PALs were exceeded. The concentrations of arsenic detected in CAU 410 soils are considered representative of ambient conditions at the TTR (NMBG, 1998; Moore, 1999; SNL, 1999); therefore, no corrective action is necessary for the soil containing arsenic.

The purpose of this CADD/CR is to provide justification and documentation supporting the recommendation for closure of CAU 410 with no further corrective action. To achieve this, the following actions were performed:

- Initial field activities detailed in the corrective action investigation plan (CAIP) (NNSA/NV, 2002a) were conducted from October 28 through November 7, 2002.

- Based on the results of the initial field activities, supplemental field activities detailed in Records of Technical Change (ROTCs) No. 1 through No. 4 of the CAIP (NNSA/NV, 2002a) were conducted between March 3 and October 22, 2003.

- The current site conditions and the nature and extent of contamination were reviewed upon the completion of the supplemental field activities.

- All UXO, soil, and waste debris was disposed of in accordance with the CAIP (NNSA/NV, 2002a), associated ROTCs, and applicable regulations.

- The closure of CAU 410 was documented.

Results from the supplemental field activities associated with the removal of depleted uranium contaminated waste and UXO at CASs TA-19-002-TAB2 and TA-21-002-TAAL, and removal of hydrocarbon waste at CAS 03-19-001, indicate that no further corrective action is necessary for these CASs. Results from the initial investigation of TA-21-002-TANL and 09-21-001-TA09 indicate no contamination in excess of PALs is present. Therefore, no further action is necessary at these CASs. 
No use restrictions are required to be placed on this CAU because the investigation showed no evidence of remaining soil contamination or remaining debris/waste upon completion of all investigation activities. Therefore, the U.S. Department of Energy, National Nuclear Security Administration Nevada Site Office (NNSA/NSO) provides the following recommendations:

- No further corrective action is required at CAU 410.

- No Corrective Action Plan is required.

- A Notice of Completion to NNSA/NSO is requested from the Nevada Division of Environmental Protection for closure of CAU 410.

- Corrective Action Unit 410 should be moved from Appendix III to Appendix IV of the Federal Facility Agreement and Consent Order. 


\subsection{Introduction}

This Corrective Action Decision Document/Closure Report (CADD/CR) has been prepared for Corrective Action Unit (CAU) 410: Waste Disposal Trenches, Tonopah Test Range (TTR), Nevada, in accordance with the Federal Facility Agreement and Consent Order (FFACO) that was agreed to by the State of Nevada, the U.S. Department of Energy (DOE), and the U.S Department of Defense (FFACO, 1996).

The TTR, which is included in the Nevada Test and Training Range (formerly called the Nellis Air Force Range), is approximately 235 miles (mi) northwest of Las Vegas, Nevada (Figure 1-1).

Corrective Action Unit 410 is located in Area 3, Area 9, south Antelope Lake, and the northern area of the Nonviolent Explosive Destruct System (NEDS) Lake at the TTR (Figure 1-2). The CAU contains five correction action sites (CASs). All were investigated in accordance with the Corrective Action Investigation Plan (CAIP) (NNSA/NV, 2002a). Table 1-1 lists the five CASs investigated and their associated facilities.

Table 1-1

CAU 410 Corrective Action Sites and Associated Facilities

\begin{tabular}{||l|l|l|l||}
\hline \multicolumn{1}{|c|}{ Location } & \multicolumn{1}{c|}{ CAS Number } & \multicolumn{1}{c|}{ CAS Description } & \multicolumn{1}{c|}{ Facility Association } \\
\hline \hline NEDS Lake & TA-21-003-TANL & Disposal Trench & NEDS Lake \\
\hline Area 9 & 09-21-001-TA09 & Disposal Trenches & Area 9 \\
\hline NEDS Lake & TA-19-002-TAB2 & Debris Mound & Bunker 2 \\
\hline Antelope Lake & TA-21-002-TAAL & Disposal Trench & Antelope Lake (southern end) \\
\hline Area 3 & 03-19-001 & Waste Disposal Site & Area 3, Building 0385 \\
\hline
\end{tabular}

The CADD and CR have been combined into one report because no further action is recommended for this CAU. The CADD/CR provides or references the specific information necessary to support this recommendation. 


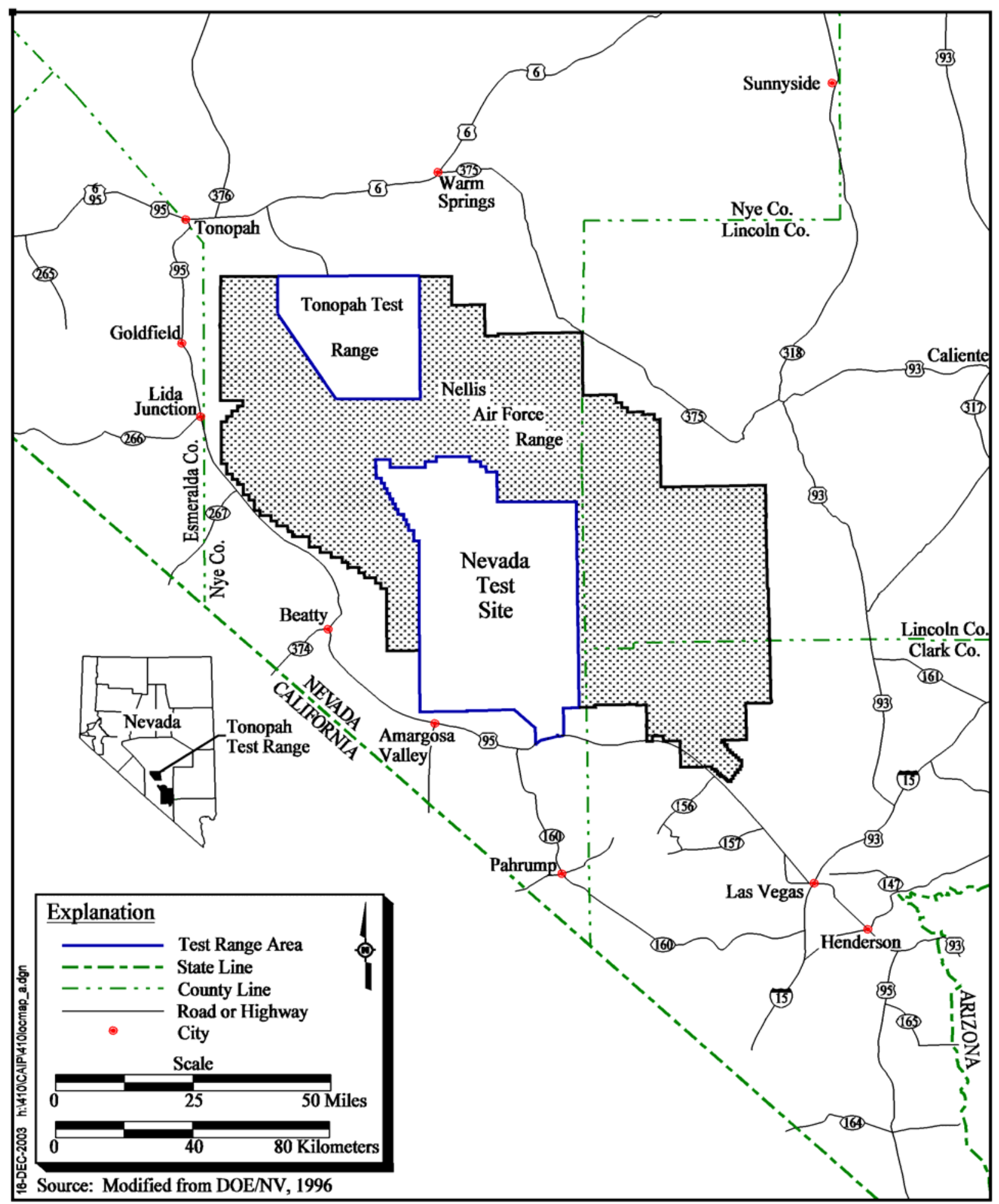

Figure 1-1

Tonopah Test Range Location Map 


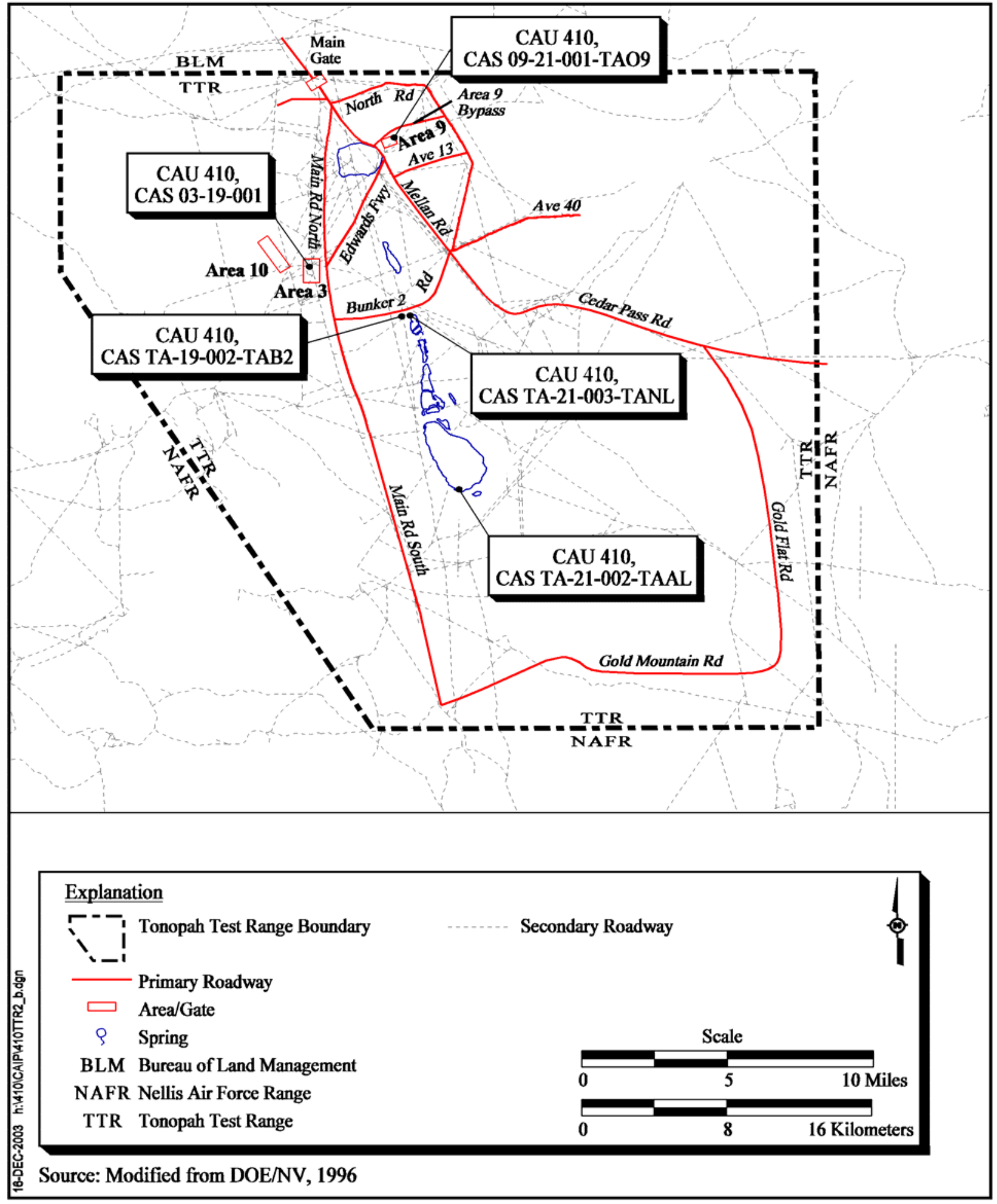

Figure 1-2

TTR CAU 410 CAS Location Map 


\subsection{Purpose}

The Waste Disposal Trenches included in CAU 410 were historically used for disposal of miscellaneous waste debris and ordnance waste. In addition, two of the five sites have associated depleted uranium (DU)-contaminated soil and debris. Other contaminants associated with the sites include total petroleum hydrocarbons (TPH). The CAIP for Corrective Action Unit 410: Waste Disposal Trenches Tonopah Test Range, Nevada (NNSA/NV, 2002a), provides additional information relating to the history, planning, and scope of the investigation; therefore, it will not be repeated in this $\mathrm{CADD} / \mathrm{CR}$.

The purpose of this CADD/CR is to provide justification for the closure of CAU 410 without further corrective action. This justification is based on process knowledge and the results of the investigative activities conducted in accordance with the CAIP (NNSA/NV, 2002a) and the corresponding Record of Technical Changes (ROTCs).

No further action is appropriate because all necessary conditions for closure of the CAU have been met as a result of the activities associated with the supplemental field investigation. The nature of the supplemental field investigation on three of the CASs (i.e., excavation, segregation, and separation of soil, debris, and/or unexploded ordnance [UXO] to determine nature and extent) resulted in each CAS being free of contamination greater than Preliminary Action Level (PAL) concentrations and free of waste/debris or UXO. As there is no contamination greater than PALs remaining at any of the CASs, no risk assessment is required.

\subsection{Scope}

The scope of this CADD/CR is to justify and recommend that no further corrective action is required at CAU 410. To achieve this scope, the following actions were implemented:

- Initial field activities detailed in the CAIP (NNSA/NV, 2002a) were conducted from October 28 through November 7, 2002.

- Based on the results of the initial field activities, supplemental field activities detailed in ROTCs No. 1 through No. 4 of the CAIP (NNSA/NV, 2002a) were conducted between March 3 and October 22, 2003. 
- Current site conditions and the nature and extent of contamination were reviewed upon the completion of the supplemental field activities.

- A Notice of Completion was documented for closure of CAU 410.

- All UXO, soil, and waste debris were disposed of in accordance with the appropriate ROTCs, CAIP (NNSA/NV, 2002a), and applicable regulations.

\section{$1.3 \quad C A D D / C R$ Contents}

This CADD/CR is divided into the following sections:

Section 1.0 - Introduction: summarizes the purpose, scope, and contents of this CADD/CR.

Section 2.0 - Corrective Action Investigation Summary: summarizes the investigation field activities, the results of the investigation, and the justification for no further action.

Section 3.0 - Recommendation: recommends no further corrective action and closure of CAU 410.

Section 4.0 - References: provides a list of all referenced documents.

Appendix A - Corrective Action Investigation Results for CAU 410: Waste Disposal Trenches, Tonopah Test Range, Nevada: provides a description of the project objectives, field investigation and sampling activities, investigation results, waste management, and quality assurance. Section A.3.0 through Section A.7.0 provide CAS-specific information regarding field activities, sampling methods, and laboratory analytical results from the investigation.

Appendix B - Data Assessment for CAU 410: summarizes the investigation results as they meet the requirements set forth during the data quality assessment process.

Appendix C - Risk Assessment for CAU 410: Waste Disposal Trenches, Tonopah Test Range, Nevada: summarizes the risk assessment results.

Appendix D - Closure Activities and Waste Disposition for CAU 410: summarizes the closure activities, waste management activities, and the verification sampling activities and results. 
Appendix E - Waste Manifests for CAU 410: provides the copies of waste manifests generated during disposal activities.

Appendix F - Nevada Division of Environmental Protection (NDEP) Comment Responses: contains responses to NDEP comments on the Draft CADD.

\subsubsection{Supporting Documentation}

All work was performed in accordance with the following documents:

- Corrective Action Investigation Plan for Corrective Action Unit 410: Waste Disposal Trenches, Tonopah Test Range, Nevada (NNSA/NV, 2002a)

- Industrial Sites Quality Assurance Project Plan (QAPP) (NNSA/NV, 2002b)

- Federal Facility Agreement and Consent Order (1996)

- Project Management Plan (DOE/NV, 1994)

To address the preliminary findings of the CAU 410 investigations conducted in October and November 2002, the following ROTCs were completed to allow for supplemental field activities to be completed:

- The February 19, 2003, ROTC No. 1 to the CAIP outlined the proposed removal of contaminated soil from CAS 03-19-001, Waste Disposal Site.

- The February 19, 2003, ROTC No. 2 to the CAIP outlined the proposed removal of contaminated soil and debris from CAS TA-19-002-TAB2, Debris Mound, and the removal of debris from CAS TA-21-002-TAAL, Disposal Trench (i.e., Antelope Lake).

- The March 10, 2003, ROTC No. 3 to the CAIP outlined the proposed removal of additional contaminated soil from CAS 03-19-001, Waste Disposal Site, at depths greater than identified in ROTC No. 1.

- The April 21, 2003, ROTC No. 4 to the CAIP outlined the removal of UXO and ordnance debris from CAS TA-19-002-TAB2, Debris Mound, and the removal of debris from CAS TA-21-002-TAAL, Disposal Trench (i.e., SW Antelope Lake). 
- The March 14, 2003, ROTC No. 1 to the Field Management Plan for Corrective Action Unit 410: Waste Disposal Trenches, Tonopah Test Range, Nevada, provided guidance for supplemental field activities.

\subsubsection{Data Quality Objectives}

The Data Quality Objectives (DQOs) identified in the CAIP are as follows:

- Determine if contaminants of concern (COCs) are present.

- If COCs are present, determine their nature and extent.

The Data Quality Indicators (DQIs) as discussed in Appendix B, were achieved. The DQOs, established in the CAIP, were met. Excavation activities conducted to define the nature and extent of contaminants of potential concern (COPCs) resulted in the removal of contamination above PALs at these CASs; therefore, no risk assessment is required for CAU 410. 


\subsection{Corrective Action Investigation Summary}

The following section summarizes the CAU 410 investigation activities, investigation results, and presents the justification for no further action. For detailed investigation activities and results, refer to Appendix A. Refer to Appendix D for detailed closure-type activities that resulted from best management practices implemented during supplemental field activities.

\section{$2.1 \quad$ Investigation Activities}

The initial field activities as set forth in the CAIP (NNSA/NV, 2002a) were performed from October 28 through November 7, 2002. The supplemental field activities were performed as set forth in the four ROTCs from March 3 through October 22, 2003. The activities at all CASs include:

- Prefield activities, including debris removal, construction of hazardous waste accumulation areas (HWAAs), utility clearances

- UXO surveys

- Radiological walk-over surveys

- Collecting waste management samples

- Collecting biased surface and subsurface soil samples, and subsequent laboratory analysis, to define the lateral and vertical extent of COCs

- Conducting discrete field screening of select samples for characterization and health and safety purposes

- Collecting Global Positioning System (GPS) coordinates of sampling locations

- Collecting select GPS coordinates to define the limits of work areas at select CASs

The following sections summarize the activities at each CAS (see Appendix A for additional details). 


\subsubsection{CAS TA-21-003-TANL, Disposal Trench}

Investigation activities conducted in October 2002 consisted of one trench excavated through the center of the depression to a depth of about 2 feet (ft) below ground surface (bgs) (see Figure A.5-1). The eastern end of the existing depression was excavated to investigate an anomaly identified during the 2002 geophysical survey (Shaw, 2002). Excavation of this anomaly revealed an empty tin can with no apparent staining or elevated radiological screening measurements.

Since no biasing factors were encountered (i.e., elevated field-screening results [FSRs]), two soil samples were collected from the native-soil interface in accordance with the CAIP. The first sampling location (410NL001) was approximately 4 to $4.5 \mathrm{ft}$ below the original ground surface on the western end of the depression within the excavated trench. Sample 410NL002 and duplicate 410NL003 were collected from the native soil interface beneath the tin can. The excavation trench was backfilled and no further activities were conducted at this CAS. Based on investigation results, the conceptual site model (CSM) was valid.

\subsubsection{CAS 09-21-001-TA09, Disposal Trenches}

No buried debris was identified during the geophysical surveys; therefore, in accordance with the CAIP, surface samples were collected from low spots within the CAS. Surface sample 41009001 was collected from the western end of the CAS, and surface sample 41009002 and duplicate sample 41009003 were collected from the eastern end of the CAS. During the sampling activities, which were conducted with a hand auger, native soils consisting of cemented caliche were encountered. Since native soils were encountered at the two sampling locations and there was no apparent staining or debris, no additional sampling was conducted at this location. Based on investigation results the CSM was valid.

\subsubsection{CAS TA-19-002-TAB2, Debris Mound (Bunker Site)}

During the CAU investigation activities conducted in October and November 2002 at CAS TA-19-002-TAB2, the initial excavation at the site confirmed the presence of subsurface debris at the mound area. The debris material appeared to be confined to the mound area and within the limits of a buried metal pan (approximately 10 by $15 \mathrm{ft}$ ). The metal pan had an open top and a 
height of approximately 12 to 18 inches (in.). The pan held materials such as soil, metal posts, UXO, drogue chutes, explosives containers, and miscellaneous debris. Due to size of the metal pan and the inability to move the metal object, the vertical extent of the debris and potentially contaminated material could not be determined. A total of six samples were collected during the initial investigation. Analytical results, as well as radiological field screening, confirmed that DU was present above PALs on the debris and in the soil contained within the metal pan.

In accordance with the ROTC No. 2 to the CAIP, further excavation activities were conducted in March 2003 to remove contaminated soil, debris, and the metal-pan in order to expose subsurface soils to define vertical extent of potential contamination. These excavation activities included the segregation and screening of DU-impacted soil and debris from ordnance. The excavation activities were completed on March 27, 2003, and six confirmation samples were collected from the sidewalls and floor of the excavation. Two east sidewall samples (410B2009 and 410B2013) collected in March and September, respectively, indicated DU still remained in the soil above PALs. The eastern sidewall had been the location of extensive excavation, removal, and waste loading of contaminated materials during supplemental field activities. Additional soil was removed on October 14, 2003, to define the lateral extent of the DU and the sidewall was resampled (410B2024). The analytical results indicate the remaining soil is below PALs and the lateral extent of DU on the east sidewall is defined. Based on investigation results, the CSM was valid.

Supplemental field activities included loading DU-impacted soil and debris into waste containers for disposal and the collection of verification samples of the ground surface. A portion of the DU waste was loaded in March 2003 with the remaining waste stockpiled until September 2003. At that time, the remaining waste was loaded. Initial verification samples collected from the former DU-waste stockpile staging area in September 2003 indicated concentrations of DU above the PAL remained on the surface (sample 410B2014). Additional soil was removed on October 14, 2003, and another nine verification samples (410B2016 to 410B2024) were collected from the former staging area and submitted to the off-site laboratory for isotopic uranium analysis. Analytical results confirmed that the remaining soil is below the action level for DU, except for one grid area on the west side of the former stockpile (410B2021). Additional soil was removed from the grid section on October 22, 2003, and one sample (410B2034) was collected. Analytical results confirm the soil is below the PAL. 
The DU-waste containers loaded in March and September 2003 were transported to the Area 3 and Area 5 Radioactive Waste Management Sites (RWMS) at the Nevada Test Site (NTS) for disposal. The additional soil removed on October 14 and October 22, 2003, was drummed and disposed of at the U10C disposal site at the NTS. The excavation was backfilled with native soil from the TTR borrow pit.

In addition to DU-impacted soil and debris, UXO was encountered within the contents of the metal pan. A total of 132 cluster bomb submunitions and one fuze were identified and segregated from the rest of the debris. The U.S. Air Force (USAF) explosive ordnance disposal (EOD) personnel inspected the cluster bomb submunitions and determined they were inert. Of the 132 cluster bomb submunitions, 35 were contaminated with DU. The 97 cluster bomb submunitions not contaminated were moved to the USAF recycle pile located on range. The remaining 35 were demilitarized by USAF EOD personnel and Shaw Environmental, Inc. (Shaw) UXO personnel to qualify for final disposition into the low-level radioactive waste (LLW) landfill. These activities were conducted in accordance with the ROTC No. 4 to the CAIP, which outlined the removal of UXO and ordnance debris from CAS TA-19-002-TAB2, Debris Mound. A summary of the final disposition of all ordnance uncovered during all CAU investigation activities is presented in Appendix D.

\subsubsection{CAS TA-21-002-TAAL, Disposal Trench (Antelope Lake)}

During the initial CAU investigation activities conducted in November 2002, the excavation activities did not define the horizontal and vertical extent of the debris due to the nature of the materials and the limited capability of the equipment. The buried debris, which consisted of a variety of material including metallic debris, UXO, and steel wire, was greater in vertical and lateral extent than suggested by geophysical surveys and process knowledge. At the completion of this initial phase, two soil samples were collected from the southern and northern trenches and submitted for laboratory analyses.

Based on the information gathered during the initial investigation, ROTC No. 2 to the CAIP proposed additional excavation be completed as a supplemental field activity to the CAIP/DQO process. The supplemental activities focused on the excavation; segregation; and separation of soil, 
debris, and UXO while defining the nature and extent of potential contamination in subsurface soils. The additional excavation activities commenced on March 11, 2003, and were completed on March 20, 2003. During these excavation activities, the soils in the excavation were field screened for high explosives (HE) and radiological constituents. Field-screening results indicated that Royal Demolition Explosive (RDX) was not above the field-screening levels (FSLs) in the soils. Therefore, the limits of the excavation were defined by the presence of UXO and debris. On the northern portion of the excavation, elevated radiological field-screening results (FSRs) indicated the presence of DU on soils and debris. Excavation of the waste disposal trenches continued to define the extent of DU contamination after implementing the necessary hazard controls (i.e., radiological work permit). As the excavation progressed, a total of 13 soil characterization samples were collected to confirm that the boundaries of the excavation were not impacted by the COPCs and that further excavation was not warranted. The final dimensions of the excavation to define lateral and vertical extent were approximately 100 by $70 \mathrm{ft}$. The vertical depths of the excavation ranged from $14 \mathrm{ft}$ on the eastern side to less than $5 \mathrm{ft}$ on the western side. Based on investigation results, the CSM was valid.

The detection of DU warranted further segregation of the soils, debris, and UXO to isolate the DU-impacted material from nonimpacted material. Supplemental field activities included the loading of DU-impacted soil and debris into containers for disposal. The disposal activities, along with the collection of samples for waste characterization are detailed in Appendix D. Initial surface verification samples collected from the former DU-waste stockpile staging areas in September 2003 indicated concentrations of DU above the PAL remained on site (410AL018). Additional soil was removed on October 14, 2003, and another nine verification samples were collected and submitted to an off-site laboratory for isotopic uranium analysis (410AL021 to 410AL029). Analytical results confirmed that the remaining soil is below the action level for DU.

In addition to nonhazardous and DU-impacted materials, over 1,000 pieces of UXO were identified. The initial screening and segregation of UXO was conducted as the soil was first excavated and stockpiled. Upon subsequent visual inspections of the soil stockpiles Nos. 1, 2, 4, and the DU-waste stockpile, it was discovered that additional UXO still remained in these stockpiles. Between June and September 2003 these soil stockpiles were rescreened through a more refined process to identify and properly segregate additional UXO. All UXO recovered from the 
excavation were segregated and properly disposed by either demilitarization or scrap recycling between the months of March through September 2003. The UXO contaminated with DU were demilitarized by USAF EOD and Shaw UXO personnel to qualify for final disposition to the LLW landfill at the NTS. Any uncontaminated UXO determined inert by the USAF EOD personnel were moved to the USAF recycle pile on range. These activities were conducted in accordance with the ROTC No. 4 to the CAIP, which outlined the removal of UXO and ordnance debris from CAS TA-21-002-TAAL, Disposal Trench. The number and various types of ordnance, and their final disposition, are presented in Appendix D.

All DU waste that was loaded into approved containers during September 2003 was transported for disposal at the Area 3 and Area 5 RWMSs at the NTS. The additional soil removed on October 14, 2003 was drummed and disposed of at the U10C disposal site at the NTS. Nonhazardous waste that was excavated, segregated, and stockpiled was loaded into haul trucks and disposed at the TTR construction landfill. The excavation was backfilled with native soil from the TTR borrow pit.

\subsubsection{CAS 03-19-001, Waste Disposal Site}

During the October 2002 investigation, a trench was excavated approximately 12 to $15 \mathrm{ft}$ south of the original SWS-4 sample location where FSLs were exceeded for TPH-diesel-range organics (DRO) during the CAU 405 investigation. Five soil samples were collected from the locations designated in the CAIP. Neither debris nor stained soil were observed in the sides and/or bottom of the trench, and TPH field screening indicated no contamination. The five samples collected confirmed the absence of TPH within the excavation.

As a best management practice, it was decided to excavate the TPH-contaminated soil and burned debris encountered at the CAU 405 SWS-4 location based on the assumption that contamination was restricted to the immediate vicinity at a depth of 4.5 to $5.5 \mathrm{ft}$ bgs. Therefore, ROTC No. 1 to the CAIP was approved for supplemental field activities to include excavation, segregation, and separation of debris and soil based on FSRs and visual observation of staining.

The supplemental field activities were conducted under ROTCs No. 1 and No. 3 between March and May 2003. Investigation results under ROTC No. 1 indicated debris and staining to greater 
depths and lateral extent than anticipated. Excavation to determine the nature and extent of potential TPH contamination continued under ROTC No. 3. Various investigation tools such as exploratory potholes, hollow-stem auger drilling, and excavation were used to remove all of the debris from the burn pit area. Because previous sampling of the stained soil indicated TPH was not associated with debris/staining within the burn pit area, only photoionization detector (PID) field screening was implemented for sample selection. During these supplemental activities, a distinct area of TPH soil contamination above the NDEP action levels (100 milligrams per kilogram $[\mathrm{mg} / \mathrm{kg}])(\mathrm{NAC}, 2002)$ was encountered at the southern end of the burn pit. This TPH area was treated as a separate investigation area for the purposes of field screening, sample collection, and waste segregation. A series of verification soil samples were collected between March and May 2003 for both the burn pit and TPH areas. The samples were submitted for off-site laboratory analysis of COPCs. Analytical results confirm remaining soil is below PALs. Based on investigation results, the CSM was valid.

The nature and extent of the burned debris, soil staining, and TPH-contaminated soil was characterized and defined by sample collection and analysis. The excavated materials were separated and segregated for proper disposal. The TPH contamination was removed for disposal at the Area 6 hydrocarbon disposal site at the NTS. Nonimpacted waste was disposed at the TTR construction landfill. The excavation was backfilled with native soil from the TTR borrow pit.

\section{$2.2 \quad$ Results}

Summary characterization data from the corrective action investigation are provided in Section 2.2.1. This information illustrates the degree of characterization accomplished through the investigation and identifies those COPCs that exceeded PALs as COCs. Section 2.2.2 summarizes the assessment made in Appendix B, which demonstrates the correlation between the investigation results and the DQOs.

\subsubsection{Summary of Analytical Data}

Chemical and radiological results for characterization samples in each of the CASs are summarized in Section 2.2.1.1 through Section 2.2.1.5. The PALs for the CAU 410 investigation were 
determined during the DQO process and are discussed in Section 3.3 of the CAIP (NNSA/NV, 2002).

\subsubsection{CAS TA-21-003-TANL, Disposal Trench}

The analytical results for soil samples collected at TA-21-003-TANL indicated that COCs are not present in the soil at this site. The soil samples were submitted for the following analysis: total volatile organic compounds (VOCs), total semivolatile organic compounds (SVOCs), total Resource Conservation and Recovery Act (RCRA) metals, HE, total beryllium, gamma spectrometry, TPH-DRO and gasoline-range organics (GRO), isotopic uranium (U), and isotopic plutonium.

\subsubsection{CAS 09-21-001-TA09, Disposal Trench}

The analytical results for soil samples collected at 09-21-001-TA09 indicated that COCs are not present in the soil at this site. The soil samples were submitted for the following analysis: total VOCs, total SVOCs, total RCRA metals, HE, and gamma spectrometry.

\subsubsection{CAS TA-19-002-TAB2, Debris Mound}

The analytical results for the final verification soil samples collected at TA-19-002-TAB2 during supplemental field activities indicate that COCs are not present in the soil at this site. Site characterization samples collected during the initial October and November 2002 investigation were compared to PALs for the following parameters: total VOCs, total SVOCs, total RCRA metals, HE, gamma spectrometry, and isotopic uranium. Subsequent to the supplemental excavation activities conducted in March 2003 to determine extent of contamination, verification samples were compared to PALs for the following parameters: total VOCs, total SVOCs, total RCRA metals, HE, total beryllium, gamma spectrometry, TPH-DRO and -GRO, polychlorinated biphenyls (PCBs), pesticides, herbicides, isotopic uranium, and isotopic plutonium. Following the additional soil removal activities in September and October 2003, verification samples were compared to PALs for isotopic uranium and/or PCBs. 
Although bismuth-212, thorium-234, U-234, U-235, and U-238 were detected in several verification soil samples at concentrations exceeding PALs, a normalized difference test determined these results are statistically indistinguishable from the PAL; therefore, are not considered COCs (Alderson, 2003). However, samples 410B2009 and 410B2013 (eastern sidewall of the excavation) and 410B2014 (former stockpile area) were statistically higher than the PAL for U-235 and U-238, prompting additional soil removal from the eastern sidewall and former stockpile area. Soil was excavated and removed by hand on October 14, 2003, and eight additional verification samples analyzed for isotopic uranium (410B2016 through 410B2024). After applying the normalized difference test, one of these samples (410B2021) was determined to exceed the PAL. Additional soil was removed and one sample (410B2034) collected on October 22, 2003. This most recent analytical result indicates uranium concentrations in the remaining soil are below PALs.

\subsubsection{CAS TA-21-002-TAAL, Disposal Trench}

The analytical results for investigation/verification soil samples collected at TA-21-002-TAAL indicated that COCs are not present in the soil at this site. Investigation and verification soil samples from both the initial and supplemental investigations were submitted for the following analysis: total VOCs, total SVOCs, total RCRA metals, HE, total beryllium, gamma spectrometry, TPH-DRO and -GRO, isotopic uranium, and isotopic plutonium. The only exception is for verification samples 410AL017 to 410AL029, which were only analyzed for isotopic uranium.

Bismuth-212, thorium-234, U-234, U-235, and U-238 were detected in several confirmation/ verification soil samples at concentrations exceeding PALs. A normalized difference test was performed on these samples which determined the results are statistically indistinguishable from the PAL; therefore, they are not considered COCs (Alderson, 2003). However, sample 410AL018 (former DU-stockpile area) was statistically higher than the PAL for U-235 and U-238, prompting additional soil removal from the former DU-stockpile staging areas. Soil was excavated and removed by hand on October 14, 2003, and eight additional verification samples were collected and analyzed for isotopic uranium (410AL021 to 410AL029). Statistical analysis of these most recent analytical results indicate uranium concentrations in the remaining soil are below PALs. 
Arsenic was detected above the background PAL of $23 \mathrm{mg} / \mathrm{kg}$ in several soil samples collected at this CAS. Arsenic concentrations in samples range from 8.5 to $34 \mathrm{mg} / \mathrm{kg}$. However, this is consistent with the background concentration range from 6 to $43 \mathrm{mg} / \mathrm{kg}$ in soils from locations near the TTR (SNL, 1999). Arsenic concentrations exceeded the PAL, but are considered representative of ambient conditions at the site; therefore, arsenic is not considered to be a COC for soil at this CAS.

\subsubsection{CAS 03-19-001, Waste Disposal Site}

The analytical results for soil samples collected at CAS 03-19-001 indicated the only COC present in the soil at this site was TPH-DRO (soil samples 41003009 and 41003015). These soil samples were collected to characterize soils remaining in the TPH excavation and represent soils that were subsequently removed by excavation and disposed while determining lateral and vertical extent of contamination. Verification samples collected on sidewalls and the floor of both the TPH-excavation and the burn-pit excavation, indicate that remaining subsurface soils are below the NDEP action level of $100 \mathrm{mg} / \mathrm{kg}$ (NAC, 2002). The analytical results were compared to PALs for the following parameters during the initial October/November 2002 investigation: TPH-DRO. The analytical results for samples collected during the supplemental field activities conducted in March and April 2003 were compared to PALs for multiple combinations of the following parameters: total VOCs, total SVOCs, total RCRA metals, HE, total beryllium, gamma spectrometry, TPH-DRO and -GRO, PCBs, pesticides, herbicides, isotopic uranium, and isotopic plutonium.

\subsubsection{Summary of Data Assessment}

An assessment of CAU 410 corrective action investigation results was performed to determine whether the data collected met the DQOs and could support their intended use in the decision-making process. The data assessment, provided in Appendix B, includes an evaluation of the DQIs to determine the degree of acceptability and usability of the reported data in the decision-making process. Additionally, a reconciliation of the data with the CSM established for this project was conducted. Conclusions were validated based on the results of the quality assurance (QA)/quality control (QC) measurements provided in Appendix B and discussed in Section A.8.0 of Appendix A. 
The overall results of the assessment indicate that the DQI goals for precision, accuracy, completeness, representativeness, and comparability have been achieved. Precision and accuracy of the data sets were demonstrated to be high. Evaluation of completeness indicates that sufficient information was collected to support decisions and to meet the DQOs. Representativeness of site characteristics was demonstrated with the CAU 410 data. An evaluation of comparability provides a high confidence that the data sets for the project are comparable to all other data sets generated by accepted industry standard practices (e.g., EPA SW-846). Meeting DQI goals supports acceptance of the CAU 410 data sets for meeting the DQOs established for this project and the subsequent use of this data in the decision-making process.

The CSM presented in the CAU 410 CAIP and the four ROTCs was the basis for the sample collection designs used for the site investigation. If information generated during the investigation had required a significant change in the CSM, the sampling design may not have been adequate to meet the DQOs. The reconciliation of CAU 410 corrective action investigation results to the established CSM supports the assumptions documented in the model and demonstrates completeness, representativeness, and comparability. The sampling configuration generated sufficient information to support the corrective action decision presented in Section 2.3.

\subsection{Justification for No Further Action}

Analytes detected in soil during the corrective action investigation were evaluated against PALs to determine the COCs for each CAS in CAU 410. Initial (October/November 2002) analytical results for CASs TA-21-003-TANL and 09-21-001-TA09 did not exceed PALs. Therefore, no further action was deemed necessary for the soil at these two CASs. Initial excavation and analytical results (October/November 2002) for the remaining three CASs (TA-19-002-TAB2, TA-21-002-TAAL, and 03-19-001) indicated the need for supplemental corrective action investigation activities to properly define the nature and extent of contamination. These supplemental activities were conducted March 3 to October 22, 2003, and consisted of excavating all materials for segregation and separation (i.e., soil, debris) and disposal followed by verification sampling. 
As best management practice (BMP), closure-type activities were performed at the three CASs requiring supplemental field activities. These BMP activities were performed March 10 through October 22, 2003. Refer to Appendix D for a more detailed description of the BMP (closure activities), verifications samples, and waste disposition. The closure-type activities are outlined in the following paragraphs.

\section{CAS TA-19-002-TAB2}

- Excavated all materials including the metal pan to access subsurface soils for characterization

- Loaded DU-contaminated soil and debris waste into B25 boxes, a transportainer, 55-gallon drums, and super sacks for disposal

- Collected waste characterization samples from contents of B25 box containers

- $\quad$ Segregated all UXO from soil and debris

- Conducted radiological surveys of debris for waste determination

- Demilitarized UXO contaminated with DU

- Dispositioned inert UXO to USAF recycle pile

- Collected verification samples from sidewalls and floor of excavation and ground surface of former stockpile staging area

- Transported all DU-waste containers to the NTS

- Backfilled the excavation and regraded as close to original grade as possible

- Transported solid waste generated in October 2003 to the NTS

\section{CAS TA-21-002-TAAL}

- Excavated all materials from the disposal trenches to access subsurface soils for characterization

- Segregated all UXO and DU-contaminated materials from nonhazardous soil and debris

- Demilitarized potentially live UXO and DU-contaminated UXO 
- Collected verification samples from sidewalls and floor of excavation and ground surface at former DU-waste stockpile staging areas

- Backfilled the excavation as close to original grade as possible

- Collected waste management profile samples for each stockpile of soil/debris for waste determination

- Transported and disposed uncontaminated, inert UXO to USAF recycle pile

- Disposed of nonhazardous aluminum scrap to USAF recycle piles

- Loaded DU-contaminated soil and debris waste into super sacks, transportainer, and 55-gallon drums for disposal

- Hauled municipal solid waste (approximately 1,604 tons) to the Piot Landfill at the TTR

- Transported all DU-waste containers to the NTS

- Transported solid waste generated in October 2003 to the NTS

\section{CAS 03-19-001}

- Segregated and stockpiled clean overburden (as determined by field screening), visibly stained soil and debris from the burn pit excavation, and TPH-contaminated soil/debris

- Collected waste management samples for waste determination

- Collected verification samples from sidewalls and floor of burn pit and TPH excavations

- Hauled approximately 302 tons of municipal solid waste to the Piot Landfill at the TTR for disposal

- Hauled approximately 230 tons of TPH-contaminated soil and debris to the NTS hydrocarbon landfill for disposal

- Backfilled the excavation and regraded as close to original grade as possible

The analytical results for the final verification samples for CASs TA-19-002-TAB2, TA-21-002-TAAL, and 03-19-001 did not exceed corresponding levels of concern for TPH, arsenic, or radiological constituents. As anticipated, the supplemental field activities resulted in these three CASs being free of contamination greater than PALs and free of remaining debris and 
CAU $410 \mathrm{CADD} / \mathrm{CR}$

Section: 2.0

Revision: 0

Date: $12 / 22 / 2003$

Page 21 of 24

UXO. Based on the sample analytical results and the actions described above, no further action is necessary at any of the five CASs that comprise CAU 410. 


\subsection{Recommendations}

Based on the results of the corrective action investigation activities discussed in the previous sections and detailed in Appendix A, no further corrective action is required for CAU 410. Results from the supplemental field activities associated with the removal of DU-contaminated waste and UXO at CASs TA-19-002-TAB2 and TA-21-002-TAAL, and removal of TPH-contaminated waste at CAS 03-19-001, presented in Appendix A, indicate that no further corrective action is necessary for these CASs. Therefore, the U.S. Department of Energy, National Nuclear Security Administration Nevada Site Office (NNSA/NSO) provides the following recommendations:

- No further corrective action is required at CAU 410.

- No Corrective Action Plan is required.

- A Notice of Completion to NNSA/NSO is requested from the NDEP for closure of CAU 410.

- $\quad$ CAU 410 should be moved from Appendix III to Appendix IV of the FFACO.

No use restrictions are required to be placed on this CAU because the investigation showed no evidence of remaining soil contamination or remaining debris/waste upon completion of all investigation activities. 


\subsection{References}

Alderson, S., Shaw Environmental, Inc. 2003. Memo to D. Arnold (SAIC) entitled, "CAU 410

PAL Comparison and Review for Radioanalytical Samples Associated with CASs

TA-19-002-TAB2 and TA-21-002-TAAL," 28 August. Las Vegas, NV.

DOE/NV, see U.S. Department of Energy, Nevada Operations Office.

FFACO, see Federal Facility Agreement and Consent Order.

Federal Facility Agreement and Consent Order. 1996 (as amended). Agreed to by the State of Nevada, the U.S. Department of Energy, and the U.S. Department of Defense.

Moore, J., Science Applications International Corporation. 1999. Memorandum to M. Todd (SAIC) entitled, "Background Concentrations for NTS and TTR Soil Samples," 3 February. Las Vegas, NV: IT Corporation.

NAC, see Nevada Administrative Code.

NBMG, see Nevada Bureau of Mines and Geology.

NNSA/NV, see U.S. Department of Energy, National Nuclear Security Administration Nevada Operations Office.

Nevada Administrative Code. 2002. NAC 445A.2272, "Contamination of Soil: Establishment of Action Levels." Carson City, NV.

Nevada Bureau of Mines and Geology. 1998. Mineral and Energy Resource Assessment of the Nellis Air Force Range, Open-File Report 98-1. Prepared by J.V. Tingley, S.B. Castor, S.I. Weiss, L.J. Garside, J.G. Price, D.D. LaPointe, H.F. Bonham, and T.P. Lugaski. Reno, NV.

Shaw, see Shaw Environmental and Infrastructure, Inc.

SNL, see Sandia National Laboratories.

Sandia National Laboratories. 1999. 1998 Annual Site Environmental Report, Tonopah Test Range, Nevada, SAND99-2279. Albuquerque, NM.

Shaw Environmental and Infrastructure, Inc. 2002. Results of Geophysical Survey Corrective Action Unit 410, Tonopah Test Range, Tonopah, Nevada. Sacramento, CA. 
U.S. Department of Energy, National Nuclear Security Administration Nevada Operations Office. 2002a. Corrective Action Investigation Plan for Corrective Action Unit 410: Waste Disposal Trenches, Tonopah Test Range, Nevada, Rev. 0, DOE/NV--676. Las Vegas, NV.

U.S. Department of Energy, National Nuclear Security Administration Nevada Operations Office. 2002b. Industrial Sites Quality Assurance Project Plan, Nevada Test Site, Nevada, Rev. 3, DOE/NV--372. Las Vegas, NV.

U.S. Department of Energy, Nevada Operations Office. 1994. Project Management Plan, Rev. 0. Las Vegas, NV.

U.S. Department of Energy, Nevada Operations Office. 1996. Corrective Action Unit Work Plan, Tonopah Test Range, Nevada, DOE/NV--443. Las Vegas, NV. 


\section{Appendix A}

Corrective Action Investigation Results for CAU 410: Waste Disposal Trenches

Tonopah Test Range, Nevada 


\section{A.1.0 Introduction}

This appendix presents the corrective action investigation (CAI) activities and analytical results for CAU 410, which is located within the TTR. The TTR is included in the Nevada Test and Training Range (formerly called the Nellis Air Force Range), and is approximately $235 \mathrm{mi}$ northwest of Las Vegas, Nevada (Figure 1-1). The five CASs that comprise CAU 410 are:

- TA-21-003-TANL, Disposal Trench

- 09-21-001-TA09, Disposal Trenches

- TA-19-002-TAB2, Debris Mound

- TA-21-002-TAAL, Disposal Trench

- 03-19-001, Waste Disposal Site

These five CASs are located in Area 3, Area 9, south Antelope Lake, and the northern area of NEDS Lake at the TTR (Figure 1-2). The CAU sites, with the exception of CAS 03-19-001, are classified as disposal trenches and debris mounds from high explosives and ordnance-related tests. The trenches vary in configuration and range in use from borrow pits to backfill holes. The Area 3 CAS (03-19-001) was added to CAU 410 as a result of CAU 405 investigation activities that identified debris and soil staining outside the original scope of the CAU 405 SWS-4 location.

The corrective action investigation was conducted in accordance with the requirements set forth in the CAIP for CAU 410 (NNSA/NV, 2002a), as developed under the FFACO (1996).

Additional information relating to the site history, planning, and scope of the investigation is presented in the CAIP (NNSA/NV, 2002a) and will not be repeated in this appendix.

\section{A.1.1 Project Objectives}

The following were the primary objectives for the investigation:

- Determine if COPCs are present within the waste debris and/or soil.

- Determine whether the COPCs, if present, exceed regulatory levels (if they do, they become COCs). 
- Define the lateral and vertical extent of contamination.

- Generate sufficient information and data to satisfy DQO data needs and develop appropriate corrective action alternatives.

The selection of locations for soil sample collection were based on field screening, site conditions, and the strategy devised in the DQO process as outlined in the CAIP (NNSA/NV, 2002a).

\section{A.1.2 Report Content}

This report contains information and data in sufficient detail to support the recommendation for no further action in the CADD/CR. The contents of this report are listed below:

- Section A.1.0 describes the investigation background, objectives, and the report content.

- Section A.2.0 provides information regarding field activities and sampling methods.

- Section A.3.0 summarizes the investigation results for CAS TA-21-003-TANL, Disposal Trench.

- Section A.4.0 summarizes the investigation results for CAS 09-21-001-TA09, Disposal Trenches.

- Section A.5.0 summarizes the investigation results for CAS TA-19-002-TAB2, Debris Mound.

- Section A.6.0 summarizes the investigation results for CAS TA-21-002-TAAL, Disposal Trench.

- Section A.7.0 summarizes the investigation results for CAS 03-19-001, Waste Disposal Site.

- Section A.8.0 discusses the QA and QC procedures that were followed and the results of the QA and QC activities.

- Section A.9.0 is a summary of the investigation results for CAU 410.

- Section A.10.0 lists the cited references.

The complete field documentation and laboratory data, including Field Activity Daily Logs (FADLs) Sample Collection Logs, Analysis Request/Chain-of-Custody Forms, soil sample descriptions, laboratory certificates of analyses, analytical results, and surveillance results are retained in the project files. 


\section{A.2.0 Investigation Overview}

The CAU 410 field investigation was conducted between October 29, 2002 and October 22, 2003. Initial investigation activities were conducted in October and November 2002. Based on the excavation and analytical results, it was determined that supplemental field activities were required to fully characterize three of the five CASs within CAU 410. Beginning in March 2003, CASs TA-19-002-TAB2, TA-21-002-TAAL, and 03-19-001 were further characterized to define the nature and extent of potential soil contamination and debris. Excavation was the primary method used to investigate all of the CASs except for CAS 09-21-001-TA09, which was investigated with a hand auger. In addition, hollow-stem auger drilling was used to assist in defining impacted soil at CAS 03-19-001, Waste Disposal Site.

The investigation and sampling program was managed in accordance with the requirements set forth in the CAIP and ROTCs No. 1 through No. 4 (NNSA/NV, 2002a). Field activities were performed under an approved site-specific health and safety plan (IT, 2002a). Samples were collected by following approved protocols and procedures for sample collection, decontamination, chain of custody, shipping, and field screening as indicated in the CAIP (NNSA/NV, 2002a) and documented using FADLs, soil boring logs, and sample collection logs. The QC samples (e.g., field blanks, equipment rinsate blanks, trip blanks, and sample duplicates) were collected as required by the CAIP (NNSA/NV, 2002a), the Industrial Sites QAPP (NNSA/NV, 2002b), and approved procedures.

\section{A.2.1 Deviations}

Deviations from the CAIP occurred at three CASs from CAU 410 resulting in the generation of four ROTCs to the CAIP and supplemental field activities. Initial trenching operations in October/ November 2002 at CASs TA-19-002-TAB2, TA-21-002-TAAL, and 03-19-001 indicated vertical extents of debris and potentially impacted soil greater than predicted in the CAIP. The limited capabilities of the backhoe equipment during the initial trenching operations prevented the adequate characterization of vertical and lateral extent of debris and impacted soil at these CASs. This resulted in the need for supplemental field activities, which began in March 2003, including changes to the scope of the investigation to include segregation and separation of nonimpacted soil 
from the DU-waste, UXO, and TPH-contaminated soil for waste disposal. Details regarding the CAS-specific deviations and resulting ROTCs to the CAIP are discussed in the individual CAS sections of this appendix.

\section{A.2.2 Preliminary Conceptual Model}

A single CSM was developed for CAU 410 using assumptions formulated from historical background information, knowledge from studies of similar sites, geophysical surveys, and data from previous sampling efforts. Appendix A of the CAIP provides information on the CSM as presented for DQO formulation. In general, the conceptual model was consistent for all five CASs with the exception of CAS 03-19-001 where the physical configuration was different than anticipated.

\section{A.2.3 Sample Locations}

In general, sample locations were collected as planned in the CAIP during the initial investigation. The planned sample locations for the initial investigation conducted in October/November 2002 are depicted in Figure 4-1 through Figure 4-5 in the CAIP (NNSA/NV, 2002a). The actual sample locations collected during both the initial and supplemental field investigations are depicted in various figures in each CAS-specific section. Sample locations collected during supplemental field actives focused on defining lateral and/or vertical extent of contaminated soil within excavations. The locations were selected at the discretion of the Site Supervisor and were based on visual observations, site conditions, and/or FSRs.

Documentation of sample locations were completed by a combination of GPS technology and fieldlocated based on tape measurements and/or landmark features. Collecting GPS coordinates at most sample locations was prohibited due to safety concerns with regard to the depth of excavations. Since the deep excavations were not backfilled immediately, sample locations were noted in FADLs and reconstructed in figures based on surface features (e.g., building corners or excavation walls).

\section{A.2.4 Investigation Activities}

Investigation activities included soil sampling from backhoe excavations, hollow-stem auger borings, and surface sampling; segregation and separation of soil, debris, and UXO waste streams; 
and UXO demilitarization. Waste characterization and disposal activities were also performed as a result of large volumes of investigation-derived waste (IDW) generated by the investigation.

\section{A.2.4.1 Field Screening}

Field-screening activities for VOC, TPH, HE, and alpha and beta/gamma radiation were performed as specified in the CAIP. The FSL for VOC headspace was established at 20 parts per million (ppm). The FSL for TPH was 75 ppm. The FSL for HE was 10 ppm. The site-specific FSLs for alpha and beta/gamma radiation were defined as the mean background activity level plus two times the standard deviation. Field screening was conducted using a PID for VOCs, Petroflag test kit for TPH, RDX EnSys soil test kit for HE, and an NE Technologies Electra for alpha and beta/gamma radiation.

\section{A.2.4.2 Intrusive Investigation Activities}

All five CASs were characterized by surface and/or subsurface soil sampling. Soil samples were collected using "scoop and trowel" or grab-sampling, hand auger, excavator, and hollow-stem auger drilling. Site observations of debris and/or stained soil, and FSRs were used to guide the extent of intrusive activities and determine sampling horizons. Investigation intervals and soil samples were field screened for one or more of the following: VOCs, TPH, HE, and alpha and beta/gamma radiation. The FSRs were compared against FSLs to guide the investigation and selection of samples for laboratory analysis. In addition to FSRs, other biasing factors used in the selection of biased sample locations were obvious debris or soil staining, site conditions, and professional judgement. Sample containers were filled with soil according to the following sequence: total VOCs and TPH-GRO sample containers were filled directly from the surface location, excavator bucket, or split-spoon sampler, followed by the collection of soil for VOC, TPH, or HE field screening. Additional soil was transferred into a stainless-steel bowl, homogenized, and screened for alpha and beta/gamma radiation. All remaining sample containers were then filled. If VOCs and TPH-GRO were not required, the soil was immediately transferred to the stainless-steel bowl. Selected samples were shipped to off-site laboratories to be analyzed for appropriate chemical and radiological parameters. Sample media collected but not submitted to the laboratory was returned to the collection site or placed in a waste stockpile, if applicable. 
The trenching/excavation activities involved the removal of large volumes of soil, debris, and UXO to expose sampling horizons and determine site boundaries. Debris, soil mixed with debris, and/or UXO removed from an excavation was separated and placed in designated areas pending disposal. If visual observation and field screening did not indicate the presence of COPCs, the spoils were placed directly on the ground surface. In the case of TPH-contaminated soil with FSRs exceeding FSLs, the soil was placed on plastic and covered with plastic sheeting for protection from surface run-on and run-off. In the case of soil and debris contaminated with DU, the waste had to be handled twice due to the nature of the excavation activities, so spoils were placed directly on the ground. Where these contaminated soils contacted the ground surface directly, verification samples were collected after removing the stockpile for disposal to ensure all soils above PALs were disposed. Whenever possible, excavated soil with analytical results below PALs and relatively free of debris was used for backfill.

\section{A.2.5 Waste Characterization Sampling}

Because of the nature of the IDW generated at the larger excavation investigations (i.e., soil mixed with UXO or debris), it was determined that IDW would be stockpiled and disposed rather than used as backfill. Where possible, investigation samples were used to determine the waste profile to support disposal decisions; however, because most of the CASs had a limited analyte list, waste characterization samples were collected from the stockpiled IDW and analyzed for a more extensive list of analytes to support disposal decisions. The collection and analysis of these waste characterization samples followed the same procedures as investigation sampling. The specific analyses for each CAS are listed in CAS-specific sections and the analytical results are compared to Federal limits for hazardous waste, NDEP hydrocarbon action limit, landfill acceptance criteria, and the NTS Waste Acceptance Criteria (NTSWAC) established for the LLW Certification Program. Details regarding waste characterization and waste management decisions are provided in Appendix D.

\section{A.2.6 Laboratory Analytical Information}

During the initial investigation, all radiological analyses were performed by Severn Trent Laboratories in Richland, Washington, and all chemical analyses were performed by EMAX Laboratories in Torrance, California. During supplemental field investigation activities, chemical 
and radiological analyses were performed by Paragon Analytics, Inc., in Fort Collins, Colorado. The analytical parameters and laboratory analytical methods used to analyze CAU 410 investigation samples are listed in Table A.2-1. Organic, inorganic, and radiological analytical results are compared to the minimum reporting limits (MRLs) established in the CAIP (NNSA/NV, 2002).

Table A.2-1

Laboratory Analytical Parameters and Methods, CAU 410 Samples

\begin{tabular}{|c|c|}
\hline Analytical Parameter & Analytical Method \\
\hline Total volatile organic compounds & SW-846 8260B ${ }^{a}$ \\
\hline Total semivolatile organic compound & SW-846 8270C ${ }^{a}$ \\
\hline $\begin{array}{c}\text { Total petroleum hydrocarbons - gasoline-range } \\
\text { organics }\end{array}$ & SW-846 8015B (modified)a \\
\hline $\begin{array}{c}\text { Total petroleum hydrocarbons - diesel-range } \\
\text { organics }\end{array}$ & SW-846 8015B (modified) ${ }^{a}$ \\
\hline Total RCRA metals and beryllium & $\begin{array}{l}\text { Water - SW-846 6010B or } 6020 / 7470 A^{a, b} \\
\text { Soil - SW-846 6010B or } 6020 / 7471 A^{a, b}\end{array}$ \\
\hline High Explosives & SW-846 8330 \\
\hline Polychlorinated biphenyls & SW-846 8082 \\
\hline Total pesticides & SW-846 $8081 A^{a}$ \\
\hline Total herbicides & SW-846 8151A \\
\hline TCLP volatile organic compounds & SW-846 1311/8260B ${ }^{a}$ \\
\hline TCLP semivolatile organic compounds & SW-846 1311/8270C \\
\hline TCLP RCRA metals & SW-846 1311/6010B/7470A \\
\hline Gamma spectrometry & Water and Soil PAI $713 \mathrm{R}^{\mathrm{C}}$ \\
\hline Isotopic uranium & Water and Soil PAI 714R5 ${ }^{\mathrm{C}}$ \\
\hline Isotopic plutonium & Water and Soil PAI 714R7 ${ }^{\mathrm{C}}$ \\
\hline Ignitability & SW-846 1010 \\
\hline
\end{tabular}

${ }^{a}$ EPA Test Methods for Evaluating Solid Waste, Physical/Chemical Methods, 3rd Edition, Parts 1-4, SW-846 CD ROM. Washington, DC. (EPA, 1996)

${ }^{\mathrm{b}}$ Arsenic, barium, cadmium, chromium, lead, mercury, selenium, and silver

${ }^{\mathrm{c}} \mathrm{PAl}$ - Paragon Analytics, Inc.

The analytical results of samples collected from the CAU 410 investigation have been compiled and evaluated to determine the presence and/or extent of contamination in Section A.3.0 through Section A.7.0. The analytical results reported above the MRLs are summarized. The complete laboratory data packages are available in the project files. 
The analytical parameters for each of the CASs within CAU 410 were initially selected through the application of site process knowledge according to the Guidance for the Data Quality Objectives Process (EPA, 1994b) and agreed upon during the DQO meeting. The analytical method TPH-DRO includes the carbon range C10 - C38 and will be referred to as TPH-DRO throughout this report. When TPH is used without further designation, it refers to TPH in general and may be used in conjunction with sampling or field-screening methodology. Total petroleum hydrocarbon-GRO includes the carbon range from C6 - C10.

Bioassessment samples were not collected because field investigation activities that resulted in the removal of all TPH contamination precluded the need. Geotechnical samples were not collected because investigation techniques resulted in the removal of landfill/disposal wastes thereby precluding the need for geotechnical parameters used to engineer landfill caps.

\section{A.2.7 Comparison to PALs}

Chemicals and radionuclides detected in samples at concentrations greater than PALs are identified as COCs. If COCs are present, corrective action must be considered for the CAS. The PALs for the CAU 410 investigation were identified and agreed to during the DQO process. For organic and inorganic COPCs (except TPH), the PALs are the EPA Region 9 Preliminary Remediation Goals (PRGs) under the industrial scenario (EPA, 2000b). The PAL for TPH is $100 \mathrm{mg} / \mathrm{kg}$ per the NAC 445A.2272 (NAC, 2002).

Background concentrations for metals have been used instead of PRGs when the natural background concentration exceeds the PRG, as is often the case with arsenic. Background is considered the mean plus two times the standard deviation for sediment samples collected by the Nevada Bureau of Mines and Geology throughout the Nevada Test and Training Range (formerly the Nellis Air Force Range) (NBMG, 1998; Moore, 1999). At the TTR, background concentrations range from 6 to $43 \mathrm{mg} / \mathrm{kg}$ in soils (SNL, 1999). Arsenic concentrations detected within this range are considered representative of ambient conditions at the site.

Radionuclide concentrations measured in CAU 410 environmental samples were compared to isotope-specific PALs. A radionuclide PAL is defined as the maximum concentration in an environmental sample taken from an undisturbed background location in the vicinity of the NTS 
and throughout the state of Nevada or the minimum detectable concentration (MDC) if the isotope is not reported or reported below the MDC (NNSA/NV, 2002a). The PALs for cesium-137, U-234, U-235, U-238, plutonium-238, and plutonium-239/240 are listed in Table 3-2 of the CAIP (NNSA/NV, 2002a).

The PALs for the naturally-occurring, gamma-emitting radionuclides actinium-228, bismuth-212, bismuth-214, lead-212, lead-214, radium-226, thorium-232, thorium-234, and thallium-208 were established from the characterization gamma spectroscopy data reported in the Environmental Monitoring Report for the Proposed Ward Valley, California, Low-Level Radioactive Waste Facility by US Ecology and Atlan-Tech (1991). The PAL for the naturally-occurring, gamma-emitting radionuclide potassium-40 is established from samples collected in Beatty, Nevada, and reported in McArthur and Miller (1989). For a more detailed discussion on the PALs for the gamma-emitting radionuclides see Adams (2003).

If a sample has a positive concentration for any radionuclide with a corresponding PAL, the sample result and its PAL concentration data are statistically compared. The normalized difference test is used for this comparison (Paar and Porterfield, 1997). The test is defined as:

$$
\mathrm{t}=\frac{\mathrm{R}-\mathrm{PAL}}{\sqrt{\sigma_{\mathrm{R}}^{2}+\sigma_{\mathrm{PAL}}^{2}}}
$$

where:

$$
\begin{aligned}
& \mathrm{t}=\text { Normalized Difference Result } \\
& \mathrm{R}=\text { Sample Radioanalytical Result } \\
& \mathrm{PAL}=\text { Preliminary Action Level } \\
& \mathrm{F}_{\mathrm{R}^{2}}=2 \text { Sigma Uncertainty in Radioanalytical Result } \\
& \mathrm{F}_{\mathrm{PAL}}{ }^{2}=2 \text { Sigma Uncertainty in PAL }
\end{aligned}
$$

The statistical assumptions inherent to the normalized difference test are as follows:

- The sample counts are drawn from normally distributed populations.

- The counts for the sample and the PAL are centered on the sample result and the PAL.

- The width parameter of the distribution is equal to two sigma. 
The "reasonable confidence" has been set to 95 percent for this comparison test. This means that for the sample radioanalytical result to statistically differ from the PAL (with a 95 percent confidence level), the normalized difference between the PAL and the sample radioanalytical result must be greater than 1.96. If the normalized difference is less than or equal to 1.96, the sample result and the PAL differ by less than or equal to a 5 percent level of significance. If the normalized difference is greater than 1.96, there is a 95 percent confidence that the result is greater than the PAL. The result is ultimately considered to be greater than the PAL if it is statistically different than the background-based PAL.

Sample data that exceed MRLs are tabulated in the CAS-specific sections that follow. Results that are greater than PALs (a subset of those that exceed PALs) are identified by bold text in the corresponding tables and discussed in Section A.3.0 through Section A.7.0. Nondetected results and results below MRLs have been excluded to minimize the size of this document. However, the unedited data set for CAU 410 is retained in an electronic format in project files.

\section{A.2.8 Geology}

Corrective Action Unit 410 and most of the TTR is located in Cactus Flat, which is an intermontane basin typical of the Basin and Range Physiographic Province. Cactus Flat is made up of Quaternary-aged alluvium eroded from the surrounding volcanic highlands (DOE/NV, 1994; USGS, 1971). Alluvium within the Cactus Flat valley may exceed 1,000 ft and is underlain by volcanic tuffs and lavas (DOE/NV, 1996). Locally, the borrow pits/disposal trenches at each CAS consisted of disturbed/reworked well-graded silty sand to gravelly sands overlying native soil. Native soil was compacted silts and silty sands in the dry playa regions (Antelope Lake and NEDS Lake) and fine to gravelly moderately consolidated sands within Area 3. The percentage of organic matter in the soil was negligible. The general field description for each sample was recorded on sample collection logs by a sample team member.

\section{A.2.9 Hydrology}

Although three CASs lie within the topographic low of Cactus Flat where the drainage of surface waters is directed towards the dry playa lakes, only CAS TA-19-002-TAB2 was considered potentially impacted by surface water due to debris and contaminants near the surface. Therefore, 
additional considerations were made for supplemental field activities necessary to ensure adequate characterization. There are no perennial streamflows or spring discharges in the Cactus Flat valley floor. The Area 3 topography slopes gently in all directions with surface drainage flowing northwest but was not considered to be critical in the characterization of the subsurface impacted soils of 03-19-001.

Groundwater depth at TTR ranges from $156 \mathrm{ft}$ bgs in Area 9 to over $350 \mathrm{ft}$ bgs at Area 3 (DOE/NV, 1996; USGS, 2001). The water table was not intercepted during any of the subsurface investigations. Due to this fact and the areas's low precipitation and high evapotranspiration rates, groundwater is not considered a migration pathway for CAU 410. 


\section{A.3.0 CAS TA-21-003-TANL, Disposal Trench}

This CAS is located at the northern end of NEDS Lake adjacent to the dry playa. The site consists of one 50 - by 20 - $\mathrm{ft}$ depression approximately $3 \mathrm{ft}$ deep. The site had been covered by an arched structure that had been moved prior to the investigation. There is no significant surface debris; however, geophysical surveys identified subsurface debris in the eastern end of the depression.

Prior to intrusive activities, UXO personnel performed an avoidance survey around the CAS footprint to identify any potential UXO and mark out the work area to protect the health and safety of workers.

\section{A.3.1 Corrective Action Investigation}

A total of two environmental soil samples were collected using a backhoe and submitted for laboratory analyses. In addition, one QC duplicate sample, one QA field blank and one QC trip blank were collected and submitted for laboratory analysis. A list of the samples collected and the parameters analyzed for are presented in Table A.3-1.

Table A.3-1

Samples Collected for CAS TA-21-003-TANL, Disposal Trench

\begin{tabular}{|c|c|c|c|c|c|c|}
\hline $\begin{array}{l}\text { Sample } \\
\text { Number }\end{array}$ & $\begin{array}{c}\text { Sample } \\
\text { Collection } \\
\text { Date }\end{array}$ & $\begin{array}{l}\text { Sample } \\
\text { Location }\end{array}$ & $\begin{array}{l}\text { Depth } \\
\text { (ft bgs) }\end{array}$ & $\begin{array}{l}\text { Sample } \\
\text { Matrix }\end{array}$ & Purpose & Analyses \\
\hline 410NL001 & \multirow{4}{*}{ 10/30/2002 } & $\begin{array}{l}\text { West End } \\
\text { of Trench }\end{array}$ & $4-4.5$ & Soil & SC, Lab QC & Set 2 \\
\hline 410NL002 & & \multirow{2}{*}{$\begin{array}{l}\text { East End } \\
\text { of Trench }\end{array}$} & $3-3.5$ & Soil & $\mathrm{SC}$ & Set 2 \\
\hline 410NL003 & & & $3-3.5$ & Soil & $\begin{array}{l}\text { Field Duplicate of } \\
\# 410 \text { NL002 }\end{array}$ & Set 2 \\
\hline 410NL301 & & $\overline{N A}$ & $\mathrm{NA}$ & Water & Trip Blank & Total VOCs \\
\hline 410NL302 & $10 / 31 / 2002$ & NA & NA & Water & Field Blank & Set 2 \\
\hline
\end{tabular}

Set 2 = Total VOCs, Total SVOCs, Total RCRA Metals, High Explosives, Total Beryllium, Gamma Spectrometry, TPH (DRO-GRO), Isotopic Uranium and Isotopic Plutonium

$\mathrm{SC}=$ Site characterization

$\mathrm{NA}=$ Not applicable

$\mathrm{QC}=$ Quality control

$\mathrm{ft}$ bgs $=$ Feet below ground surface 


\section{A.3.1.1 CAIP Implementation}

The following CAI activities were conducted to meet CAIP requirements:

- Excavated through the depression along east-west axis.

- Collected two subsurface soils samples at the native-soil interface.

- Field screened soils for alpha and beta/gamma radiation.

- Backfilled the excavation with excavated soils.

\section{A.3.1.2 Deviations}

There were no significant deviations from the CAIP. One sample location was moved from the bottom of the excavation to beneath the tin can uncovered in the excavation as a biased sample location.

\section{A.3.2 Investigation Activities}

The following sections provide CAS-specific details of excavation, field screening, and sample selection and analysis.

\section{A.3.2.1 Field Screening}

Field screening was performed as specified in the CAIP (NNSA/NV, 2002a). Samples were field screened for alpha/beta-emitting radionuclides. Since no biasing factors were observed during excavation and no indication of explosives exists within the area, the soils were not screened for explosives. Established FSLs were used to guide sample collection and to provide a basis for the selection of additional environmental samples for laboratory analyses.

\section{A.3.2.2 Excavation}

Investigation activities conducted on October 30,2002, consisted of one trench excavated through the center of the depression to a depth of approximately $2 \mathrm{ft}$ bgs (see Figure A.3-1). The eastern end of the existing depression was excavated to investigate an anomaly that was identified during the 2002 geophysical survey (Shaw, 2002). Excavation of this anomaly revealed an empty tin can with no apparent staining or elevated radiological screening measurements. 


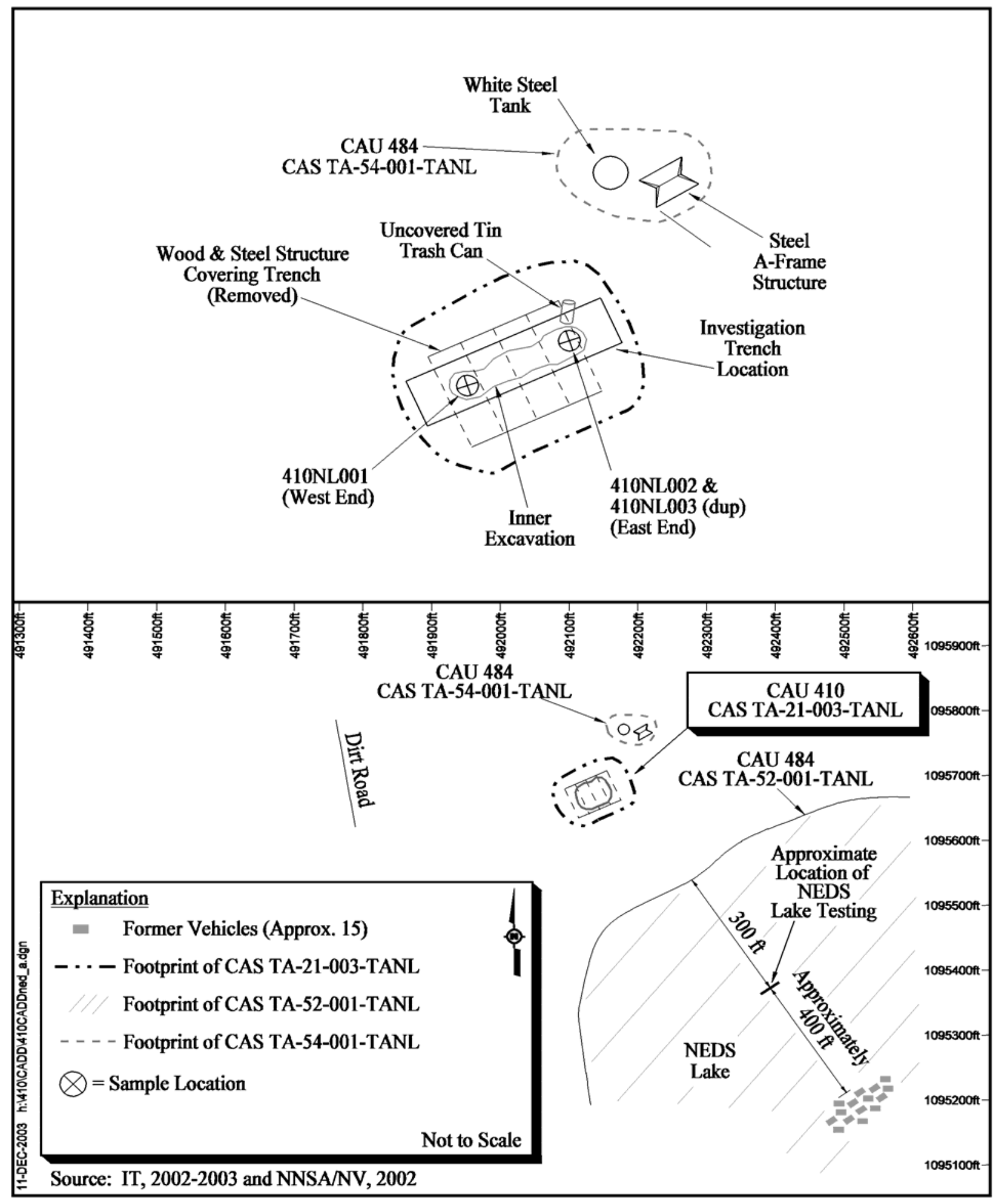

Figure A.3-1

CAU 410, CAS TA-21-003-TANL, Soil Sample Locations 
In accordance with the CAIP, two soil samples were collected from the native-soil interface within the trench at the locations presented on Figure A.3-1. Sample 410NL001 was collected from the native soil interface beneath the tin can along the slope of the depression. The second sampling location (410NL002 and duplicate sample 410NL003) was approximately 4 to $4.5 \mathrm{ft}$ below the original ground surface elevation on the western end of the depression within the excavated trench. Since the FSRs did not exceed the FSLs, contamination was not identified within or on the boundary of the trench, no additional excavation or step-out sampling was necessary. Following the collection of the two soil samples, the excavation trench was backfilled and no further activities were conducted at this CAS.

\section{A.3.2.3 Waste Characterization}

No CAS-specific waste characterization activities were performed because there was no soil waste generated.

\section{A.3.2.4 Sample Analysis}

Investigation samples were submitted for analyses including total VOCs, total SVOCs, total RCRA metals, HEs, total beryllium, TPH-DRO and -GRO, gamma spectrometry, isotopic uranium, and isotopic plutonium.

\section{A.3.3 Analytes Detected Above MRL}

The analytical results detected at concentrations exceeding the correlated MRLs at this CAS are summarized in the following sections.

\section{A.3.3.1 Total RCRA Metals Results}

The total RCRA metals results for soil samples collected from CAS TA-21-003-TANL, which were detected above MRLs, are presented in Table A.3-2. All the total metal results are below PALs (NNSA/NV, 2002a). 
Table A.3-2

Soil Sample Results for Total RCRA Metals Detected Above Minimum Reporting Limits at CAS TA-21-003-TANL

\begin{tabular}{|c|c|c|c|c|c|c|}
\hline \multirow{2}{*}{$\begin{array}{l}\text { Sample } \\
\text { Number }\end{array}$} & \multirow{2}{*}{$\begin{array}{l}\text { Sample } \\
\text { Location }\end{array}$} & \multirow{2}{*}{$\begin{array}{l}\text { Depth } \\
\text { (ft bgs) }\end{array}$} & \multicolumn{4}{|c|}{ Contaminants of Potential Concern (mg/kg) } \\
\hline & & & Arsenic & Barium & Chromium & Lead \\
\hline \multicolumn{3}{|c|}{ Preliminary Action Levels ${ }^{a}$} & $23^{b}$ & 100,000 & 450 & 750 \\
\hline 410NL001 & $\begin{array}{l}\text { West End } \\
\text { of Trench }\end{array}$ & $4-4.5$ & 6.77 & 199 & 7.23 & 9.65 \\
\hline $410 N L 002$ & \multirow{2}{*}{$\begin{array}{l}\text { East End } \\
\text { of Trench }\end{array}$} & $3-3.5$ & 4.64 & 167 & 7.78 & 117 \\
\hline 410NL003 & & $3-3.5$ & 4.68 & 150 & 8.05 & 72.2 \\
\hline
\end{tabular}

\footnotetext{
aBased on U.S. Environmental Protection Agency, Region 9 Preliminary Remediation Goals (PRGs) (EPA, 2000b)

${ }^{\mathrm{b}}$ Based on background concentrations for metals. Background is considered the mean plus two standard deviation for sediment samples collected by the Nevada Bureau of Mines and Geology throughout the Nevada Test and Training Range (NBMG, 1998; Moore, 1999).

$\mathrm{ft}$ bgs $=$ Feet below ground surface

$\mathrm{mg} / \mathrm{kg}=$ Milligrams per kilogram
}

\section{A.3.3.2 Isotopic Uranium Results}

The isotopic uranium results for soil samples collected from CAS TA-21-003-TANL, which were detected above MRLs, are presented on Table A.3-3. All isotopic uranium results are below PALs (NNSA/NV, 2002a).

Table A.3-3

Soil Sample Results for Isotopic Uranium Detected Above Minimum Reporting Limits at CAS TA-21-003-TANL

\begin{tabular}{|c|c|c|c|c|c|}
\hline \multirow{2}{*}{$\begin{array}{l}\text { Sample } \\
\text { Number }\end{array}$} & \multirow{2}{*}{$\begin{array}{l}\text { Sample } \\
\text { Location }\end{array}$} & \multirow{2}{*}{$\begin{array}{l}\text { Depth } \\
\text { (ft bgs) }\end{array}$} & \multicolumn{3}{|c|}{ Contaminants of Potential Concern (pCi/g) } \\
\hline & & & Uranium-234 & Uranium-235 & Uranium-238 \\
\hline \multicolumn{3}{|c|}{ Preliminary Action Levels ${ }^{a}$} & 3.47 & 0.07 & 3.47 \\
\hline 410NL001 & $\begin{array}{l}\text { West End } \\
\text { of Trench }\end{array}$ & $4-4.5$ & $1.47 \pm 0.28$ & $0.0453 \pm 0.019(\mathrm{~J})$ & $1.21 \pm 0.23$ \\
\hline 410NL002 & \multirow{2}{*}{$\begin{array}{l}\text { East End } \\
\text { of Trench }\end{array}$} & $3-3.5$ & $1.4 \pm 0.27$ & $0.0536 \pm 0.021$ & $1.66 \pm 0.31$ \\
\hline 410NL003 & & $3-3.5$ & $1.22 \pm 0.23$ & $0.052 \pm 0.019$ & $1.63 \pm 0.3$ \\
\hline
\end{tabular}

${ }^{a}$ Based on background concentration listed in Environmental Monitoring Report for the Proposed Ward Valley, California, Low-Level Radioactive Waste (LLRW) Facility (US Ecology and Atlan-Tech, 1991)

$\mathrm{ft}$ bgs $=$ Feet below ground surface $\mathrm{pCi} / \mathrm{g}=$ Picocuries per gram $\mathrm{J}=$ Estimated value 


\section{A.3.3.3 Gamma-Emitting Radionuclides Results}

The gamma-emitting radionuclides results for soil samples collected from CAS TA-21-003-TANL, which were detected above MRLs, are presented on Table A.3-4. Except for potassium-40, all gamma-emitting radionuclide results were below PALs (NNSA/NV, 2002a). Potassium-40 was detected in one sample at a concentration exceeding the PAL; however, potassium-40 analytical results were evaluated using the normalized difference test as discussed in Section A.2.7, and the potassium-40 concentrations over the PAL in the soil sample are considered indistinguishable from the PAL.

\section{A.3.4 Contaminants of Concern}

Based on analytical results, there were no COCs identified in the soil.

\section{A.3.5 Nature and Extent of Contamination}

Excavation showed the geophysical anomaly on the east end of the trench was an empty tin can with no associated soil contamination. The remaining area of the depression/trench was free of contamination.

\section{A.3.6 Revised Conceptual Site Model}

No variations to the CSM were identified. 
Table A.3-4

Soil Sample Results for Gamma-Emitting Radionuclides Detected Above Minimum Reporting Limits at CAS TA-21-003-TANL

\begin{tabular}{|c|c|c|c|c|c|c|c|c|c|c|}
\hline \multirow[b]{2}{*}{$\begin{array}{l}\text { Sample } \\
\text { Number }\end{array}$} & \multirow[b]{2}{*}{$\begin{array}{l}\text { Sample } \\
\text { Location }\end{array}$} & \multirow[b]{2}{*}{$\begin{array}{l}\text { Depth } \\
\text { (ft bgs) }\end{array}$} & \multicolumn{8}{|c|}{ Contaminants of Potential Concern (pCi/g) } \\
\hline & & & 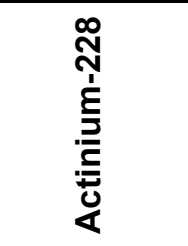 & 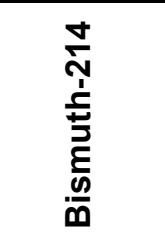 & 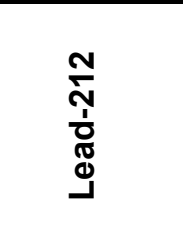 & 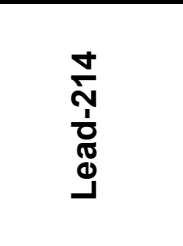 & 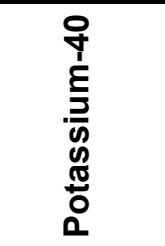 & 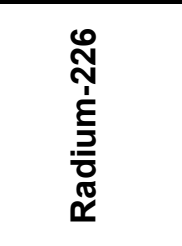 & 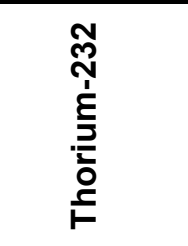 & 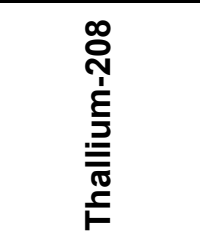 \\
\hline \multicolumn{3}{|c|}{ Preliminary Action Levels } & $3.64^{a}$ & $3.47^{a}$ & $3.64^{a}$ & $3.47^{a}$ & $30.7^{b}$ & $3.47^{a}$ & $3.64^{a}$ & $3.38^{a}$ \\
\hline 410NL001 & \begin{tabular}{|l|} 
West End \\
of Trench
\end{tabular} & $4-4.5$ & $1.97 \pm 0.44$ & -- & $1.8 \pm 0.36$ & $1.33 \pm 0.32$ & $25.8 \pm 4.1$ & $1.31 \pm 0.28$ & $2.04 \pm 0.58$ & $0.676 \pm 0.16$ \\
\hline 410NL002 & \multirow{2}{*}{$\begin{array}{l}\text { East End } \\
\text { of Trench }\end{array}$} & $3-3.5$ & $2.06 \pm 0.46$ & $2.39 \pm 0.8$ & $2.14 \pm 0.38$ & $1.19 \pm 0.29$ & $31.9 \pm 4.7$ & $1.46 \pm 0.28$ & $2.35 \pm 0.68$ & $0.731 \pm 0.15$ \\
\hline 410NL003 & & $3-3.5$ & -- & -- & $1.59 \pm 0.4$ & $1.31 \pm 0.3$ & $29.2 \pm 4.2$ & -- & $1.86 \pm 0.67$ & $0.566 \pm 0.15$ \\
\hline
\end{tabular}

aBased on background concentration reported in Environmental Monitoring Report for the Proposed Ward Valley, California, Low-Level Radioactive Waste (LLRW) Facility (US Ecology and Atlan-Tech, 1991)

${ }^{\mathrm{b}}$ Based on background concentration listed or derived in Off-Site Radiation Exposure Review Project, Phase // Soil Program (McArthur and Miller, 1989)

$\mathrm{ft}$ bgs $=$ Feet below ground surface

$\mathrm{pCi} / \mathrm{g}=$ Picocuries per gram

-- = Not detected above minimum reporting limit 


\section{A.4.0 CAS 09-21-001-TA09, Disposal Trenches}

This CAS is located on the northern side of Area 9 near Main Lake. The site consists of two perpendicular trenches that meet at the southwest corner. The east-west trench is approximately 200 - by $90-\mathrm{ft}$ and the north-south trench is approximately $270-$ by $60-\mathrm{ft}$. Each trench has a visible low spot but no staining or significant debris. Geophysical surveys did not identify any subsurface debris.

Prior to intrusive activities, UXO personnel performed an avoidance survey around the CAS footprint to identify any potential UXO and mark out the work area to protect the health and safety of workers.

\section{A.4.1 Corrective Action Investigation}

A total of two environmental soil samples were collected using hand augers and submitted for laboratory analyses. In addition, one QC duplicate sample, and one QC field blank were collected and submitted for laboratory analysis. A list of the samples collected and the parameters analyzed for are presented in Table A.4-1.

Table A.4-1

Samples Collected for CAS 09-21-001-TA09, Disposal Trenches

\begin{tabular}{|c|c|c|c|c|c|c|}
\hline $\begin{array}{l}\text { Sample } \\
\text { Number }\end{array}$ & $\begin{array}{c}\text { Sample } \\
\text { Collection } \\
\text { Date }\end{array}$ & $\begin{array}{l}\text { Sample } \\
\text { Location }\end{array}$ & $\begin{array}{l}\text { Depth } \\
\text { (ft bgs) }\end{array}$ & $\begin{array}{l}\text { Sample } \\
\text { Matrix }\end{array}$ & Purpose & Analyses \\
\hline$\overline{41009001}$ & \multirow{4}{*}{$11 / 5 / 2002$} & 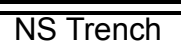 & $\overline{0-2.5}$ & $\overline{\overline{\text { Soil }}}$ & $\overline{\mathrm{SC}, \mathrm{Lab} Q \mathrm{QC}}$ & $\overline{\text { Set } 3}$ \\
\hline 41009002 & & \multirow[b]{2}{*}{ EW Trench } & $0-2.5$ & Soil & $\mathrm{SC}$ & Set 3 \\
\hline 41009003 & & & $0-2.5$ & Soil & $\begin{array}{l}\text { Field Duplicate of } \\
\quad \# 41009002\end{array}$ & Set 3 \\
\hline 41009301 & & $\overline{\mathrm{NA}}$ & $\overline{N A}$ & Water & Field Blank & Set 3 \\
\hline
\end{tabular}

Set 3 = Total VOCs, Total SVOCs, Total RCRA Metals, High Explosives, and Gamma Spectrometry

$\mathrm{SC}=$ Site characterization

NA $=$ Not applicable

$\mathrm{QC}=$ Quality control

$\mathrm{ft}$ bgs $=$ Feet below ground surface 


\section{A.4.2 CAIP Implementation}

The following CAI activities were conducted to meet CAIP requirements:

- Collected two surface soil samples for laboratory analysis

- Field screened the soil for alpha and beta/gamma radiation

\section{A.4.2.1 Deviations}

There were no deviations from the CAIP.

\section{A.4.3 Investigation Activities}

The following sections provide CAS-specific details of field screening and sample collection and analysis.

\section{A.4.3.1 Field Screening}

Field screening was performed as specified in the CAIP (NNSA/NV, 2002a). Samples were field screened only for alpha and beta/gamma radiation as no other field indicators suggested the need for additional screening for TPH or HE. None of the samples exceeded the alpha or beta/gamma FSLs.

\section{A.4.3.2 Excavation}

Since the sampling was conducted with hand augers, no excavation was conducted at this CAS.

\section{A.4.3.3 Sample Collection}

During the geophysical surveys, no subsurface buried debris was located; therefore, surface sampling was performed using a hand auger to collect soil from low spots within the CAS. Surface sample 41009001 was collected from the north-south trending depression, whereas surface sample 41009002 and duplicate sample 41009003 were collected from the east-west trending depression. The locations of these samples are shown on Figure A.4-1. Native soils consisting of cemented, caliche were encountered. Therefore, since native soils were encountered at the two sampling locations, and there was no apparent staining or debris, no additional sampling was conducted at this CAS. 


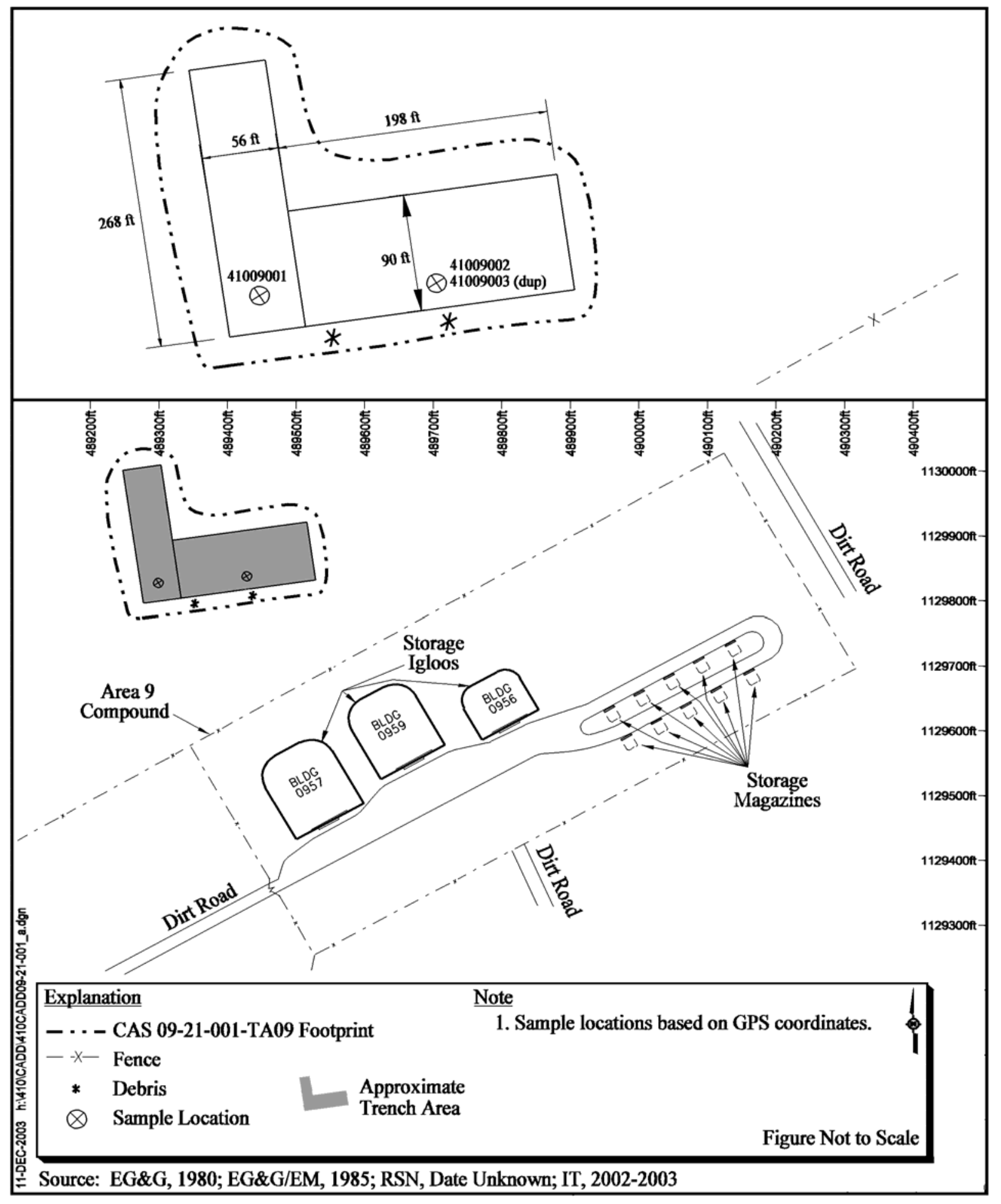

Figure A.4-1

CAU 410, CAS 09-21-001-TA09, Soil Sampling Locations 


\section{A.4.3.4 Waste Characterization}

No CAS-specific waste characterization activities were performed because there was no soil waste generated.

\section{A.4.3.5 Sample Analysis}

The analytical results for soil samples collected at TA-21-003-TANL indicated that COCs are not present in the soil at this site. The soil samples were submitted for analyses including total VOCs, total SVOCs, total RCRA metals, HEs, and gamma spectrometry.

\section{A.4.4 Analytes Detected Above MRL}

The analytical results detected at concentrations exceeding the correlated MRLs at this CAS are summarized in the following sections.

\section{A.4.4.1 Total RCRA Metals Results}

The total RCRA metals results for soil samples collected from CAS 09-21-001-TA09, which were detected above MRLs, are presented in Table A.4-2. All the total RCRA metal results are below PALs (NNSA/NV, 2002a).

Table A.4-2

Soil Sample Results for Total RCRA Metals

Detected Above Minimum Reporting Limits at CAS 09-21-001-TA09

\begin{tabular}{||c|c|c|c|c|c|c||}
\hline \multirow{2}{*}{$\begin{array}{c}\text { Sample } \\
\text { Number }\end{array}$} & \multirow{2}{*}{$\begin{array}{c}\text { Sample } \\
\text { Location }\end{array}$} & \multirow{2}{*}{$\begin{array}{c}\text { Depth } \\
\text { (ft bgs) }\end{array}$} & \multicolumn{3}{|c|}{ Contaminants of Potential Concern (mg/kg) } \\
\cline { 5 - 7 } & & Arsenic & Barium & Chromium & Lead \\
\hline \multicolumn{2}{|c|}{ Preliminary Action Levels } & & $\mathbf{2 3}^{\mathrm{b}}$ & $\mathbf{1 0 0 , 0 0 0}$ & $\mathbf{4 5 0}$ & $\mathbf{7 5 0}$ \\
\hline \hline 41009001 & NS Trench & $0-2.5$ & 7.1 & 102 & 6.65 & 6.56 \\
\hline 41009002 & \multirow{2}{*}{ EW Trench } & $0-2.5$ & 6.99 & 103 & 6.47 & 6.34 \\
\cline { 4 - 7 } & $0-2.5$ & 6.49 & 106 & 6.33 & 6.6 \\
\hline 41009003 & & &
\end{tabular}

${ }^{a}$ Based on U.S. Environmental Protection Agency, Region 9 Preliminary Remediation Goals (PRGs) (EPA, 2000b)

${ }^{b}$ Based on background concentrations for metals. Background is considered the mean plus two standard deviation for sediment samples collected by the Nevada Bureau of Mines and Geology throughout the Nevada Test and Training Range (NBMG, 1998; Moore, 1999).

$\mathrm{ft}$ bgs $=$ Feet below ground surface $\mathrm{mg} / \mathrm{kg}=$ Milligrams per kilogram 


\section{A.4.4.2 Gamma-Emitting Radionuclides Results}

The gamma-emitting radionuclides results for soil samples collected from CAS 09-21-001-TA09, which were detected above MRLs, are presented on Table A.4-3. All gamma-emitting radionuclides results are below PALs (NNSA/NV, 2002a).

\section{A.4.5 Contaminants of Concern}

Based on analytical results, there were no COCs identified in the soil.

\section{A.4.6 Nature and Extent of Contamination}

Analytical results show there is no contamination at this site.

\section{A.4.7 Revised Conceptual Site Model}

No variations to the CSM were identified. 
Table A.4-3

Soil Sample Results for Gamma-Emitting Radionuclides Detected Above Minimum Reporting Limits at CAS 09-21-001-TA09

\begin{tabular}{|c|c|c|c|c|c|c|c|c|c|}
\hline \multirow{2}{*}{$\begin{array}{l}\text { Sample } \\
\text { Number }\end{array}$} & \multirow{2}{*}{$\begin{array}{c}\text { Sample } \\
\text { Location }\end{array}$} & \multirow{2}{*}{$\begin{array}{c}\text { Depth } \\
\text { (ft bgs) }\end{array}$} & \multicolumn{7}{|c|}{ Contaminants of Potential Concern (pCi/g) } \\
\hline & & & Actinium-228 & Lead-212 & Lead-214 & Potassium-40 & Radium-226 & Thorium-232 & Thallium-208 \\
\hline \multicolumn{3}{|c|}{ Preliminary Action Levels } & $3.64^{a}$ & $3.64^{a}$ & $3.47^{a}$ & $30.7^{b}$ & $3.47^{a}$ & $3.64^{a}$ & $3.38^{\mathrm{a}}$ \\
\hline 441009001 & NS Trench & $\overline{0-2.5}$ & 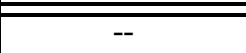 & $\overline{2.59 \pm 0.59}$ & $1.46 \pm 0.35$ & $29.3 \pm 4.5$ & 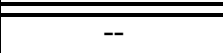 & $\overline{2.71 \pm 0.87}$ & 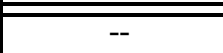 \\
\hline 41009002 & \multirow{2}{*}{ EW Trench } & $0-2.5$ & $1.36 \pm 0.48$ & $1.98 \pm 0.36$ & $1.78 \pm 0.35$ & $30.1 \pm 4.5$ & $1.56 \pm 0.31$ & $2.22 \pm 0.8$ & $0.805 \pm 0.15$ \\
\hline 41009003 & & $0-2.5$ & $1.73 \pm 0.5$ & $2.12 \pm 0.42$ & $1.78 \pm 0.38$ & $29.8 \pm 4.4$ & -- & $1.76 \pm 0.8$ & $0.567 \pm 0.16$ \\
\hline
\end{tabular}

aBased on background concentration reported in Environmental Monitoring Report for the Proposed Ward Valley, California, Low-Level Radioactive Waste (LLRW) Facility (US Ecology and Atlan-Tech, 1991)

'Based on background concentration listed or derived in Off-Site Radiation Exposure Review Project, Phase // Soil Program (McArthur and Miller, 1989)

$\mathrm{ft}$ bgs $=$ Feet below ground surface

$\mathrm{pCi} / \mathrm{g}=$ Picocuries per gram

-- = Not detected above minimum reporting limits 


\section{A.5.0 CAS TA-19-002-TAB2, Debris Mound (Bunker 2 Site)}

This CAS is located on the northern end of NEDS Lake near the Bunker 2 storage facility. The site consisted of a debris mound approximately 15 - by 20 -ft surrounded by a disturbed surface area approximately 110 - by 120 -ft. Prior to the investigation, the mound had exposed debris at the surface consistent with geophysical surveys that identified an anomaly approximately the same dimensions of the mound.

Prior to intrusive activities, UXO personnel performed an avoidance survey around the CAS footprint to identify any potential UXO and mark out the work area to protect the health and safety of workers.

\section{A.5.1 Corrective Action Investigation}

A total of 23 environmental soil samples (includes characterization and confirmation samples) were collected and submitted for laboratory analyses. In addition, two QC field duplicates, two QC field blanks, one QC equipment rinsate blank, and six QC trip blanks were collected and submitted for laboratory analysis. A list of the samples collected and the parameters analyzed for is presented Table A.5-1.

Table A.5-1 also provides sample information on the seven waste characterization soil samples collected and submitted for analysis. Although presented in this table for completeness, discussion regarding sample collection and the waste characterization analytical results are provided in Appendix D.

\section{A.5.2 CAIP Implementation}

The following CAI activities were performed to the meet the CAIP requirements:

- Excavated the debris mound to identify nature and extent of buried materials

- Field screened soils for alpha and beta/gamma radiation and HEs

- Collected subsurface samples at the native soil interface beneath debris

- Collected one surface sample downstream from debris mound

- Collected multiple confirmation samples from excavation and location of waste piles

- Segregated and separated soil, debris, and UXO for proper waste disposal 
Table A.5-1

Samples Collected for CAS TA-19-002-TAB2, Debris Mound

(Page 1 of 2)

\begin{tabular}{|c|c|c|c|c|c|c|}
\hline $\begin{array}{l}\text { Sample } \\
\text { Number }\end{array}$ & $\begin{array}{c}\text { Sample } \\
\text { Collection } \\
\text { Date }\end{array}$ & $\begin{array}{l}\text { Sample } \\
\text { Location }\end{array}$ & $\begin{array}{l}\text { Depth } \\
\text { (ft bgs) }\end{array}$ & $\begin{array}{l}\text { Sample } \\
\text { Matrix }\end{array}$ & Purpose & Analyses \\
\hline 410B2001 & \multirow{3}{*}{ 10/30/2002 } & $\begin{array}{c}\text { North Corner } \\
\text { Under Metal Tray }\end{array}$ & $2.5-3$ & Soil & SC, Lab QC & Set 1 \\
\hline 410B2002 & & \multirow{2}{*}{$\begin{array}{l}\text { South Corner } \\
\text { Under Metal Tray }\end{array}$} & $2-2.5$ & Soil & SC & Set 1 \\
\hline 410B2003 & & & $2-2.5$ & Soil & $\begin{array}{l}\text { Field Duplicate } \\
\text { of \#410B2002 }\end{array}$ & Set 1 \\
\hline 410B2004 & $10 / 31 / 2002$ & $\begin{array}{l}\text { Thirty Feet West } \\
\text { of Debris Pile }\end{array}$ & $0-0.5$ & Soil & SC & Set 1 \\
\hline 410B2005 & $11 / 6 / 2002$ & $\begin{array}{c}\text { Near West } \\
\text { Corner of Metal Tray }\end{array}$ & $0-0.5$ & Soil & SC & Gamma Spectrometry \\
\hline 410B2006 & $11 / 5 / 2002$ & NA & NA & $\begin{array}{l}\text { Unknown } \\
\text { Material }\end{array}$ & SC & $\begin{array}{c}\text { Isotopic Uranium, } \\
\text { Gamma Spectrometry }\end{array}$ \\
\hline 410B2007 & \multirow{6}{*}{$3 / 27 / 2003$} & West Sidewall & $2-3$ & Soil & Confirmation & Set 5 \\
\hline 410B2008 & & North Sidewall & $2-3$ & Soil & Confirmation & Set 5 \\
\hline 410B2009 & & East Sidewall & $2-3$ & Soil & Confirmation & Set 5 \\
\hline 410B2010 & & South Sidewall & $2-3$ & Soil & Confirmation & Set 5 \\
\hline 410B2011 & & Floor Southend & $2-3$ & Soil & Confirmation & Set 5 \\
\hline 410B2012 & & Floor Northend & $2-3$ & Soil & Confirmation & Set 5 \\
\hline 410B2013 & \multirow{3}{*}{$9 / 11 / 2003$} & East Sidewall & $2-3$ & Soil & Confirmation & $\begin{array}{c}\text { Isotopic Uranium and } \\
\text { PCBs }\end{array}$ \\
\hline 410B2014 & & Stockpile location & $0-0.5$ & Soil & Confirmation & $\begin{array}{c}\text { Isotopic Uranium and } \\
\text { PCBs }\end{array}$ \\
\hline 410B2015 & & Stockpile location & $0-0.5$ & Soil & Confirmation & $\begin{array}{l}\text { Isotopic Uranium and } \\
\text { PCBs }\end{array}$ \\
\hline 410B2016 & \multirow{9}{*}{$10 / 14 / 2003$} & Stockpile location & $0-0.5$ & Soil & Confirmation & Isotopic Uranium \\
\hline 410B2017 & & Stockpile location & $0-0.5$ & Soil & Confirmation & Isotopic Uranium \\
\hline 410B2018 & & Stockpile location & $0-0.5$ & Soil & Confirmation & Isotopic Uranium \\
\hline 410B2019 & & Stockpile location & $0-0.5$ & Soil & Confirmation & Isotopic Uranium \\
\hline 410B2020 & & Stockpile location & $0-0.5$ & Soil & $\begin{array}{l}\text { Field Duplicate of } \\
\text { \#410B2019 }\end{array}$ & Isotopic Uranium \\
\hline 410B2021 & & Stockpile location & $0-0.5$ & Soil & Confirmation & Isotopic Uranium \\
\hline 410B2022 & & Stockpile location & $0-0.5$ & Soil & Confirmation & Isotopic Uranium \\
\hline 410B2023 & & Stockpile location & $0-0.5$ & Soil & Confirmation & Isotopic Uranium \\
\hline 410B2024 & & East sidewall/stockpile & $0-0.5$ & Soil & Confirmation & Isotopic Uranium \\
\hline 410B2034 & $10 / 22 / 2003$ & Stockpile location & $0-0.5$ & Soil & Confirmation & Isotopic Uranium \\
\hline 410B2301 & $10 / 30 / 2002$ & NA & NA & Water & Trip Blank & Total VOCs \\
\hline
\end{tabular}


Table A.5-1

Samples Collected for CAS TA-19-002-TAB2, Debris Mound (Page 2 of 2)

\begin{tabular}{|c|c|c|c|c|c|c|}
\hline $\begin{array}{l}\text { Sample } \\
\text { Number }\end{array}$ & $\begin{array}{l}\text { Sample } \\
\text { Collection } \\
\text { Date }\end{array}$ & $\begin{array}{l}\text { Sample } \\
\text { Location }\end{array}$ & $\begin{array}{c}\text { Depth } \\
\text { (ft bgs) }\end{array}$ & $\begin{array}{c}\text { Sample } \\
\text { Matrix }\end{array}$ & Purpose & Analyses \\
\hline 410B2302 & \multirow[b]{2}{*}{$10 / 31 / 2002$} & $\overline{\overline{N A}}$ & $\overline{\overline{\mathrm{NA}}}$ & Water & Trip Blank & Total VOCs \\
\hline 410B2303 & & $\begin{array}{c}\text { Thirty Feet West } \\
\text { of Debris Pile }\end{array}$ & NA & Water & Field Blank & Set 1 \\
\hline 410B2304 & \multirow[b]{2}{*}{$11 / 6 / 2002$} & $\overline{\mathrm{NA}}$ & $\overline{\mathrm{NA}}$ & Water & Trip Blank & Total VOCs \\
\hline 410B2305 & & Decon Area & NA & Water & $\begin{array}{c}\text { Equipment } \\
\text { Rinsate Blank }\end{array}$ & Set 2 \\
\hline 410B2306 & $3 / 18 / 2003$ & $\overline{N A}$ & NA & Water & Trip Blank & Total VOCs \\
\hline 410B2307 & $3 / 19 / 2003$ & $\overline{N A}$ & $\overline{N A}$ & Water & Trip Blank & Total VOCs \\
\hline 410B2308 & $3 / 27 / 2003$ & $\overline{N A}$ & $\mathrm{NA}$ & Water & Trip Blank & Total VOCs \\
\hline 410B2309 & $10 / 14 / 03$ & Stockpile location & $\overline{N A}$ & Water & Field Blank & Isotopic Uranium \\
\hline 410B2501 & \multirow{2}{*}{$3 / 18 / 2003$} & $\overline{\mathrm{NA}}$ & $\overline{\mathrm{NA}}$ & Soil & WM & Set 5 \\
\hline 410B2502 & & $\overline{N A}$ & $\overline{N A}$ & Soil & WM & Set 5 \\
\hline 410B2503 & \multirow{4}{*}{ 3/19/2003 } & $\overline{N A}$ & $\overline{N A}$ & Soil & $\overline{W M}$ & Set 5 \\
\hline 410B2504 & & $\overline{N A}$ & $\overline{N A}$ & Soil & WM & Set 5 \\
\hline 410B2505 & & $\overline{\mathrm{NA}}$ & $\overline{N A}$ & Soil & WM & Set 5 \\
\hline 410B2506 & & $\overline{\mathrm{NA}}$ & $\overline{N A}$ & Soil & WM & Set 5 \\
\hline 410B2507 & $10 / 14 / 03$ & $\overline{N A}$ & $\overline{N A}$ & Soil & WM & Isotopic Uranium \\
\hline
\end{tabular}

Set $1=$ Total VOCs, Total SVOCs, Total RCRA Metals, High Explosives, Gamma Spectrometry, and Isotopic Uranium Set 2 = Total VOCs, Total SVOCs, Total RCRA Metals, High Explosives, TPH (DRO-GRO), Total Beryllium, Gamma Spectrometry, Isotopic Uranium, and Isotopic Plutonium

Set 5 = Total VOCs, Total SVOCs, Total RCRA Metals, Total Beryllium, High Explosives, TPH (DRO-GRO), Isotopic Uranium, Isotopic Plutonium, Gamma Spectrometry, PCBs, Pesticides, and Herbicides

$\mathrm{SC}=$ Site characterization

NA $=$ Not applicable

$\mathrm{QC}=$ Quality control

$\mathrm{WM}=$ Waste management

$\mathrm{ft}$ bgs $=$ Feet below ground surface 
- Conducted waste characterization sampling for waste profiles

- Disposed of all IDW from the site including the demilitarization of potentially live ordnance

- Backfilled the excavation with clean fill

\section{A.5.3 Investigation Activities}

The following sections provide CAS-specific details of excavation, field screening, and sample collection and analysis. The various phases of the initial and supplemental activities for CAS TA-19-002-TABZ are summarized in Table A.5-2.

Table A.5-2

Summary of Excavation Activities at CAS TA-19-002-TAB2

\begin{tabular}{|c|c|}
\hline Date of Activities & Activity Summary \\
\hline October 30 to 31,2002 & $\begin{array}{l}\text { Excavation activities uncovered large metal pan, debris contaminated with DU, and UXO. Samples } \\
410 \mathrm{~B} 2001 \text { to } 410 \mathrm{~B} 2004 \text { were collected. }\end{array}$ \\
\hline November 5 and 6, 2002 & $\begin{array}{l}\text { Separated and segregated UXO from debris and soil. Took inventory of types of materials and } \\
\text { replaced all soil and debris back into metal pan. Collected samples } 410 \mathrm{~B} 2005 \text { and } 410 \mathrm{~B} 2006 \text {. }\end{array}$ \\
\hline March 18 to 27,2003 & $\begin{array}{l}\text { Supplemental field activities commenced with the reexcavation of DU-contaminated materials and the } \\
\text { metal pan for disposal into waste containers. The ground surface was surveyed and the remaining } \\
\text { DU-contaminated soil was stockpiled for eventual disposal. Confirmation samples } 410 \mathrm{~B} 2007 \text { through } \\
\text { 410B2012 were collected from the floor and sidewalls of the excavation. }\end{array}$ \\
\hline April 25, 2003 & The inert cluster bomb submunitions were moved from the CAS to the recycle pile located on range. \\
\hline May 13, 2003 & $\begin{array}{l}\text { The USAF EOD and Shaw UXO personnel demilitarized the DU-contaminated cluster bomb } \\
\text { submunitions and fuze. }\end{array}$ \\
\hline September 11, 2003 & $\begin{array}{l}\text { Based on the results of sample } 410 \mathrm{~B} 2009 \text {, which had DU above PALs, additional soil was removed } \\
\text { from the east sidewall of the excavation and confirmation sample } 410 \mathrm{~B} 2013 \text { was collected. } \\
\text { Verification samples } 410 \mathrm{~B} 2014 \text { and } 410 \mathrm{~B} 2015 \text { were collected from the former stockpile area. Results } \\
\text { indicated that the soil in the east sidewall and portions of the stockpile area had DU contamination } \\
\text { remaining above PALs. }\end{array}$ \\
\hline October 14, 2003 & $\begin{array}{l}\text { Removed additional contaminated soil from the east sidewall and surface of former stockpile area. } \\
\text { Collected nine additional verification samples (410B2016 to 410B2024). The result of 410B2021 } \\
\text { indicated DU contamination above PALs remained within the grid area sampled. }\end{array}$ \\
\hline October 22, 2003 & $\begin{array}{l}\text { Removed additional soil from the grid area of sample 410B2021 and collected sample 410B2034 for } \\
\text { verification analysis. Analytical results confirm that uranium is below PALs. } \\
\text { Summary: All soils associated with elevated uranium results within the excavation and former } \\
\text { stockpile area have been excavated and removed. The most recent verification samples indicate } \\
\text { remaining soil is below PALs. }\end{array}$ \\
\hline
\end{tabular}

\section{A.5.3.1 Field Screening}

Field screening was performed as specified in the CAIP (NNSA/NV, 2002a). Established FSLs were used to guide sample collection and to provide a basis for the completion of excavation activities. Soil was field screened for HE during the initial investigation with results indicating 
FSRs below FSLs. Based on field-screening data and analytical results from November 2002, additional field screening for HEs was not conducted during the supplemental field activities.

Field-screening results for alpha and beta/gamma radiation during the initial excavation indicated debris and soil within the metal pan was contaminated with DU; however, FSRs on soil samples collected from beneath two corners of the metal tray indicated background levels. Radiological readings on solid materials within the metal pan indicated the need to post the debris mound as a Radiological Materials Area (RMA) pending supplemental field activities. Following the removal of the metal pan to reach vertical and lateral sample horizons during the supplemental field investigation, the confirmation soil samples collected in March 2003 had FSRs below FSLs.

\section{A.5.3.2 Excavation}

Due to safety concerns for potential UXO hazards within the debris mound, only essential personnel (i.e., qualified UXO personnel) were allowed to perform excavation activities within the established exclusion zone (EZ) (approximate 4,000-ft radius). A backhoe was used to excavate small lifts of material for inspection by UXO personnel. If UXO was identified, it was segregated from soil and debris. During the CAU investigation activities conducted from October 30 through November 6, 2002, the initial excavation at the site confirmed the presence of subsurface debris and ordnance at the mound area. On October 30, 2002, excavation activities identified buried debris material which appeared to be confined to the mound area and within the limits of a buried pan-shaped metal object approximately 10 - by $15-\mathrm{ft}$. The metal pan had an open top and a height of approximately 12- to 18 -inches and held materials such as soil, metal posts, UXO, drogue chutes, explosives containers, and other miscellaneous debris (Figure A.5-1). Field screening confirmed that DU contamination was present on materials. On November 5 and 6, 2002, additional excavation activities were conducted to complete UXO recovery operations due to UXO safety concerns. This work involved removing all soil and debris for UXO screening and segregation. At this time an inventory and radiological field screening of removed materials was performed as well as limited soil sampling (Figure A.5-2). Due to size of the metal pan and the inability to move the pan-shaped metal object, the vertical extent of the debris and potentially contaminated material could not be determined. All materials, except the segregated UXO, were replaced into the metal 
pan and posted as a RMA pending supplemental field activities to fully characterize the subsurface soil.

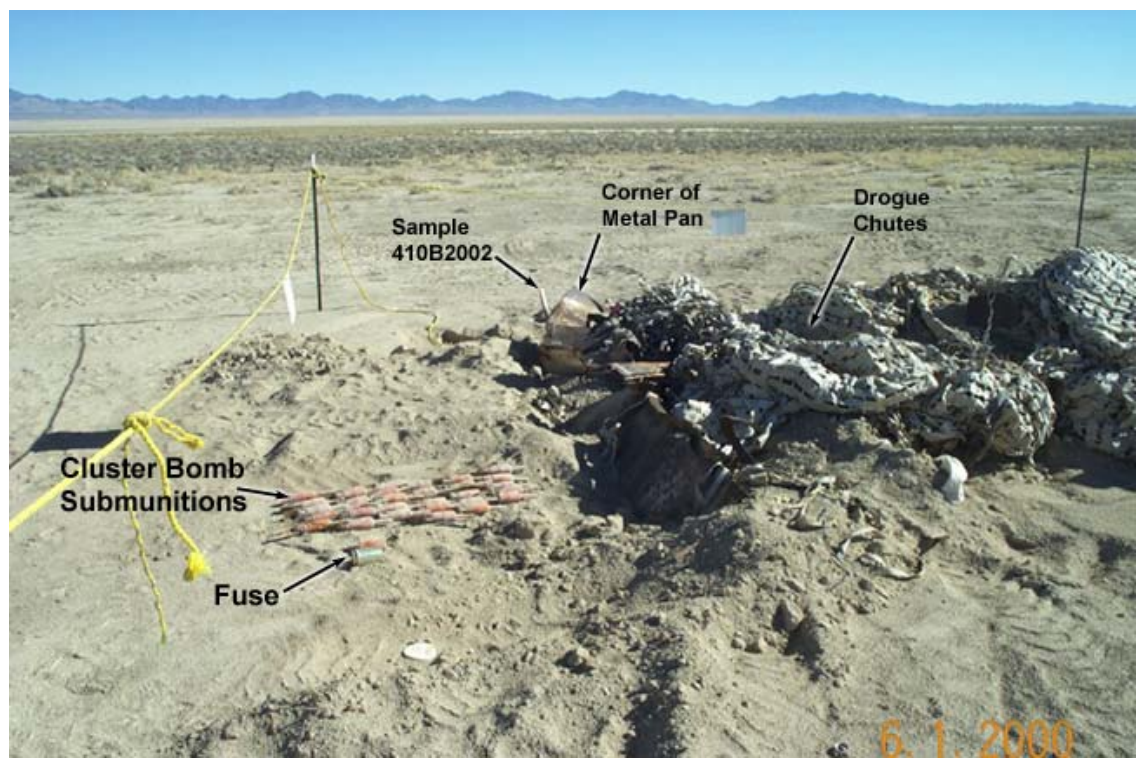

Figure A.5-1

Bunker 2 Debris

(Bunker 2 debris after being excavated, photo taken November 2002)

In accordance with ROTC No. 2, to the CAIP, which outlined the proposed removal of contaminated soil and debris from CAS TA-19-002-TAB2, further excavation activities were conducted starting March 18, 2003, to better define the extent of potential contamination. Upon the excavation and removal of all debris and the metal pan, vertical and lateral subsurface soil samples were collected for analysis to confirm the extent of contamination was delineated. The excavation activities were completed on March 27, 2003, and six confirmation samples were collected from the sidewalls and floor of the excavation. Figure A.5-3 shows the sample locations collected during both the initial and supplemental field investigations. The vertical extent of contamination was defined and confirmed by these samples. The lateral extent of contamination on three sidewalls was also defined. Two east sidewall samples (410B2009 and 410B2013) collected in March and September 2003, respectively, indicated DU still remained in the soil above PALs. The eastern sidewall had been the location of extensive excavation, removal, and waste loading of contaminated materials during supplemental field activities. Additional soil was removed to define the lateral 


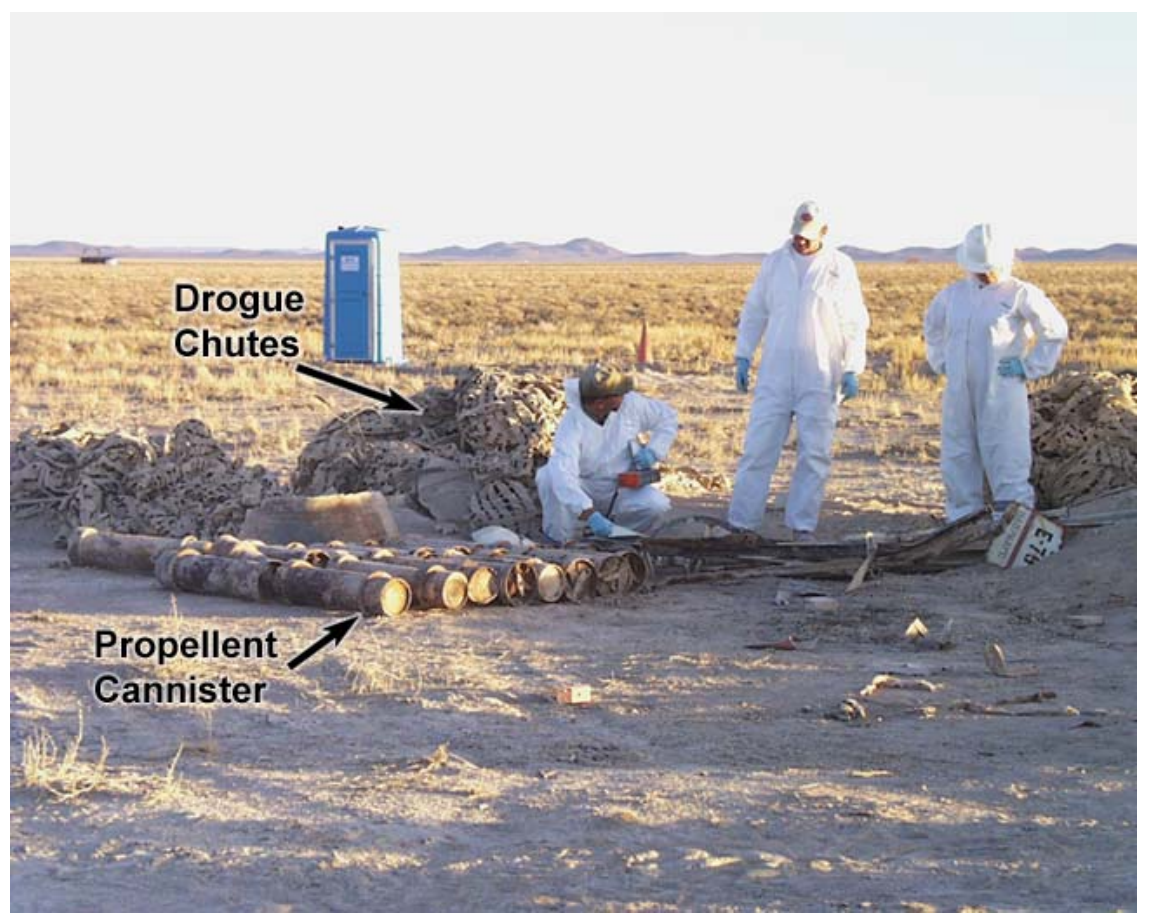

Figure A.5-2

Bunker 2 Radiological Survey

(Radiological survey of Bunker 2 debris, photo taken November 2002)

extent of the DU and the sidewall resampled on October 14, 2003 (410B2024). This analytical result was below PALs and defined the lateral extent of DU on the east sidewall at this CAS. Figure A.5-4 shows the former location of the metal pan and debris following site characterization.

The initial two verification samples collected from the ground surface of the former DU-waste stockpile area indicated DU contamination still remained. Additional soil was removed on October 14 and 22, 2003, and nine additional verification samples were collected (410B2016) to 410B2024). These results confirmed that DU in surface soil is below PALs. The disposal activities, along with the collection of samples for waste characterization, are discussed in greater detail in Appendix D. 


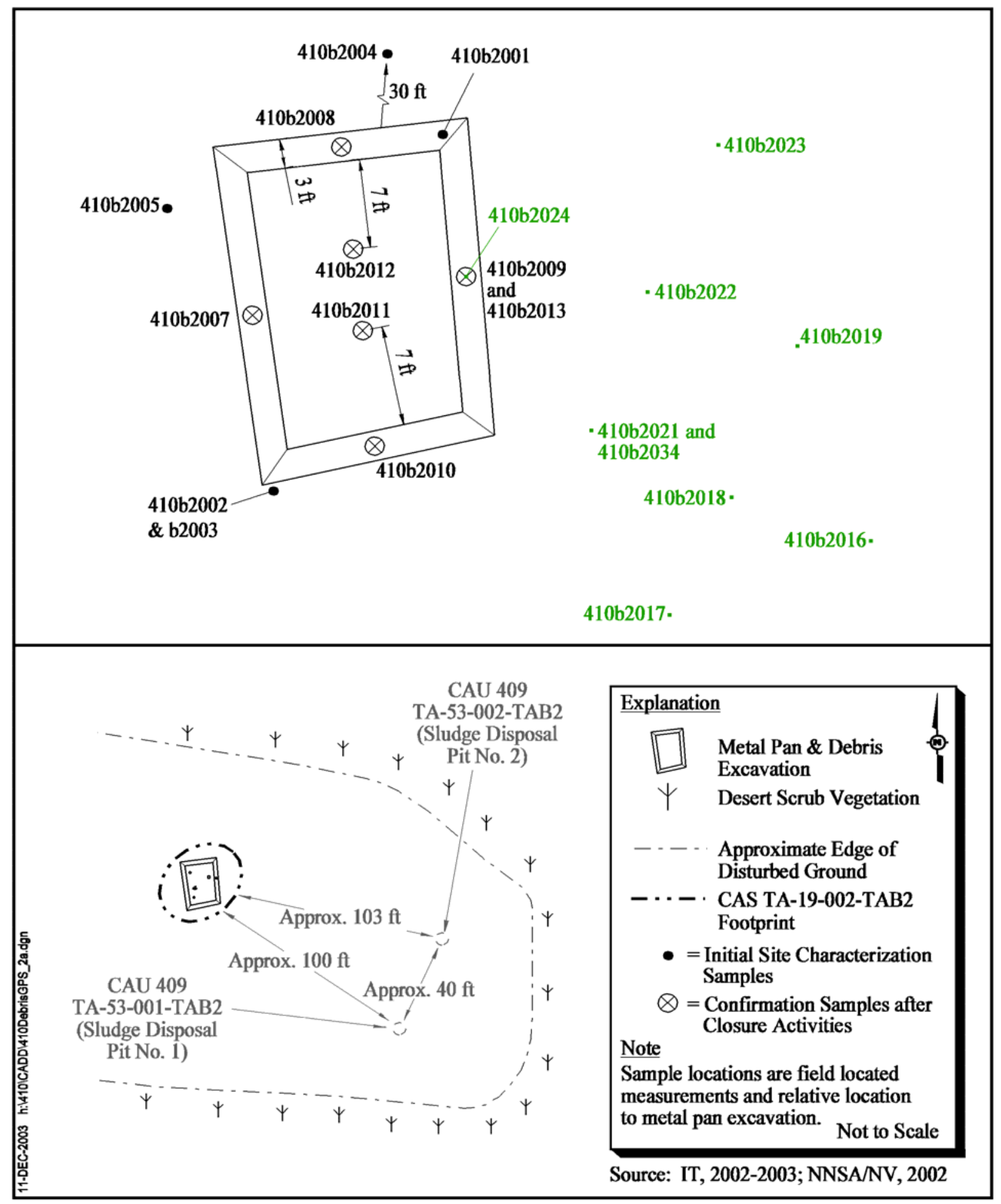

Figure A.5-3

CAU 410, CAS TA-19-002-TAB2, Soil Sampling Locations 


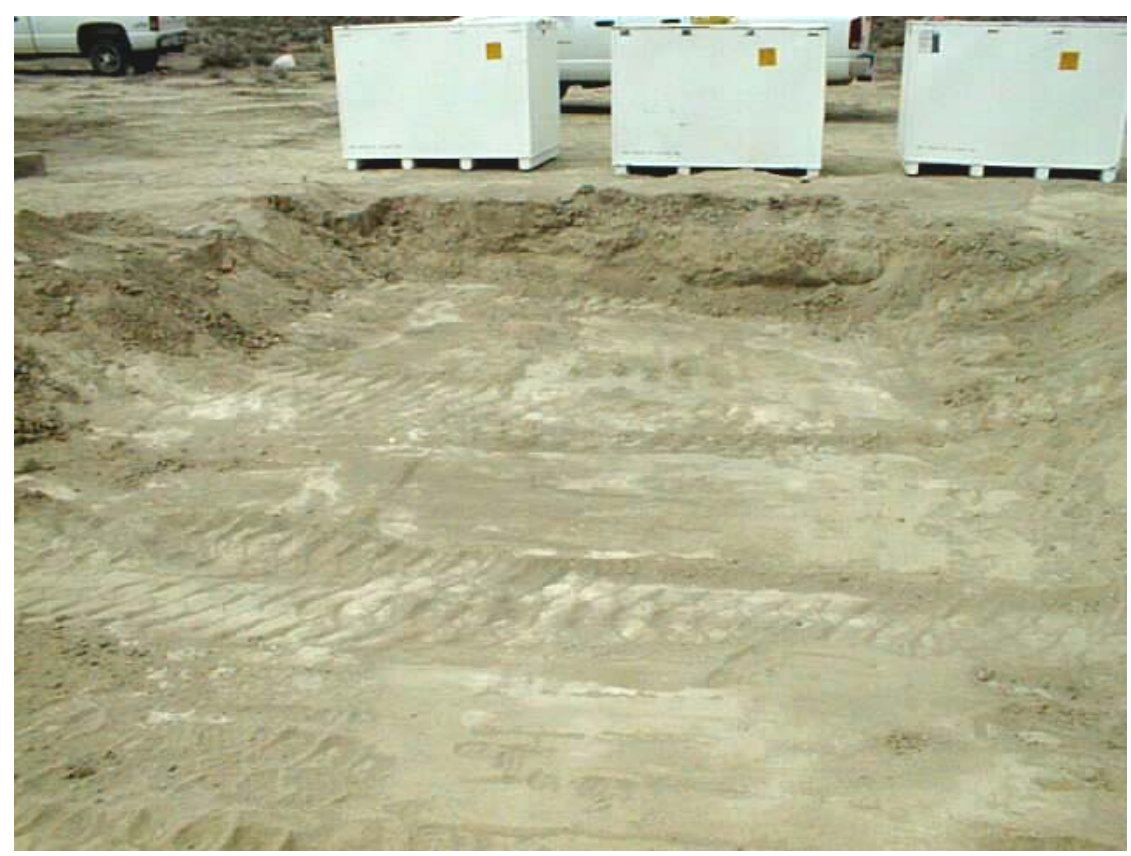

Figure A.5-4

Bunker 2 Debris

(Bunker 2 debris after being excavated, photo taken March 2003)

\section{A.5.3.3 Waste Characterization}

The DU-contaminated materials were separated and segregated prior to being loaded into waste disposal containers. Composite soil samples were collected that represented the containerized soil waste. The samples were submitted for laboratory analyses of selected analytes necessary to compare to the Waste Acceptance Criteria for disposal at the Area 3 and Area 5 RWMS or the U10C disposal site at the NTS.

In addition to DU-impacted soil and debris, 132 cluster bomb submunitions ordnance were identified and segregated from the rest of the debris (see Figure A.5-1). Of the 132 cluster bomb submunitions identified, 35 had fixed DU; therefore, were demilitarized by USAF EOD personnel. The remaining 97 cluster bomb submunitions were determined to be inert by USAF EOD personnel and were moved to the USAF recycle pile. These activities were conducted in accordance with ROTC No. 4 to the CAIP, which outlined the removal of UXO and ordnance debris from CAS 
TA-19-002-TAB2, Debris Mound. The UXO and debris disposal activities are described in greater detail in Appendix D.

\section{A.5.3.4 Sample Analysis}

Site characterization samples that were collected during the initial October and November 2002 investigation were compared to PALs for the following parameters: total VOCs, total SVOCs, total RCRA metals, HEs, gamma spectrometry, and isotopic uranium. Following supplemental excavation activities in 2003 to determine the extent of contamination, verification samples were compared to PALs for total VOCs, total SVOCs, total RCRA metals, HEs, total beryllium, gamma spectrometry, TPH-DRO and -GRO, PCBs, pesticides, herbicides, isotopic uranium, and isotopic plutonium.

\section{A.5.4 Analytes Detected Above MRL}

The analytical results detected at concentrations exceeding the correlated MRLs at this CAS are summarized in the following sections.

\section{A.5.4.1 Total VOCs}

The total VOC results for soil samples collected from CAS TA-19-002-TAB2, which were detected above MRLs, are presented on Table A.5-3. All total VOC results are below PALs (NNSA/NV, 2002a).

Table A.5-3

Soil Sample Results for Total VOCs Detected Above Minimum Reporting Limits at CAS TA-19-002-TAB2

\begin{tabular}{|c|c|c|c|c||}
\hline \multirow{2}{*}{$\begin{array}{c}\text { Sample } \\
\text { Number }\end{array}$} & \multirow{2}{*}{$\begin{array}{c}\text { Sample } \\
\text { Location }\end{array}$} & \multirow{2}{*}{$\begin{array}{c}\text { Depth } \\
\text { (ft bgs) }\end{array}$} & \multicolumn{2}{|c|}{ Contaminates of Potential Concern $(\mu \mathrm{g} / \mathrm{kg})$} \\
\cline { 3 - 5 } & & $\mathbf{1 , 2 , 3 - T r i c h l o r o b e n z e n e}$ & $\mathbf{1 , 2 , 4 - T r i c h l o r o b e n z e n e ~}$ \\
\hline \multicolumn{2}{|c|}{ Preliminary Action Levels ${ }^{\mathrm{a}}$} & $\mathrm{NI}$ & $\mathbf{3 , 0 0 0 , 0 0 0}$ \\
\hline \hline 410B2009 & East Sidewall & $2-3$ & 7.2 & 21 \\
\hline
\end{tabular}

${ }^{\mathrm{a}}$ Based on U.S. Environmental Protection Agency, Region 9 Preliminary Remediation Goals (PRGs) (EPA, 2000b)

$\mathrm{ft}$ bgs $=$ Feet below ground surface $\mu \mathrm{g} / \mathrm{kg}=$ Micrograms per kilogram $\mathrm{NI}=$ Not identified 


\section{A.5.4.2 Total Metals}

The total metals results for soil samples collected from CAS TA-19-002-TAB2, which were detected above MRLs, are presented on Table A.5-4. All total metals results are below PALs (NNSA/NV, 2002a).

Table A.5-4

Soil Sample Results for Metals Detected Above Minimum Reporting Limits at CAS TA-19-002-TAB2

\begin{tabular}{|c|c|c|c|c|c|c|c|c|}
\hline \multirow{2}{*}{$\begin{array}{l}\text { Sample } \\
\text { Number }\end{array}$} & \multirow{2}{*}{$\begin{array}{c}\text { Sample } \\
\text { Location }\end{array}$} & \multirow{2}{*}{$\begin{array}{l}\text { Depth } \\
\text { (ft bgs) }\end{array}$} & \multicolumn{6}{|c|}{ Contaminants of Potential Concern (mg/kg) } \\
\hline & & & Arsenic & Barium & Beryllium & Cadmium & Chromium & Lead \\
\hline \multicolumn{3}{|c|}{ Preliminary Action Levels ${ }^{a}$} & $23^{b}$ & 100,000 & 2,200 & 810 & 450 & 750 \\
\hline 410B2001 & $\begin{array}{c}\text { North Corner } \\
\text { Under Metal } \\
\text { Tray }\end{array}$ & $2.5-3$ & 4.11 & 106 & -- & -- & 5.16 & 7.1 \\
\hline 410B2002 & \multirow{2}{*}{$\begin{array}{c}\text { South Corner } \\
\text { Under Metal } \\
\text { Tray }\end{array}$} & $2-2.5$ & 4.32 & 129 & -- & -- & 7.41 & 8.88 \\
\hline $410 \mathrm{~B} 2003$ & & $2-2.5$ & 4.33 & 124 & -- & -- & 6.99 & 8.7 \\
\hline 410B2004 & $\begin{array}{c}\text { Thirty Ft West of } \\
\text { Debris Pile }\end{array}$ & $0-0.5$ & 3.43 & 130 & -- & -- & 5.91 & 9.25 \\
\hline 410B2007 & West Sidewall & $2-3$ & 5.7 & 110 & 0.81 & -- & 6.2 & 9.8 \\
\hline 410B2008 & North Sidewall & $2-3$ & 6.7 & 100 & 0.71 & -- & 5.4 & 8.7 \\
\hline 410B2009 & East Sidewall & $2-3$ & 6.3 & 110 & 0.72 & 0.85 & 6.5 & 10 \\
\hline 410B2010 & South Sidewall & $2-3$ & 5.9 & 100 & 0.67 & -- & 5.1 & 9.1 \\
\hline 410B2011 & Floor Southend & $2-3$ & 6.1 & 150 & -- & -- & 3.6 & 7 \\
\hline 410B2012 & Floor Northend & $2-3$ & 8.4 & 120 & 0.68 & - & 5.4 & 7.4 \\
\hline
\end{tabular}

aBased on U.S. Environmental Protection Agency, Region 9 Preliminary Remediation Goals (PRGs) (EPA, 2000b)

${ }^{\mathrm{b}}$ Based on background concentrations for metals. Background is considered the mean plus two standard deviation for sediment samples collected by the Nevada Bureau of Mines and Geology throughout the Nevada Test and Training Range (NBMG, 1998; Moore, 1999).

$\mathrm{ft}$ bgs $=$ Feet below ground surface $\mathrm{mg} / \mathrm{kg}=$ Milligrams per kilogram

-- = Not detected above minimum reporting limits

\section{A.5.4.3 PCBs}

The PCBs results for soil samples collected from CAS TA-19-002-TAB2, which were detected above MRLs, are presented on Table A.5-5. All results are below PALs (NNSA/NV, 2002a). 
Table A.5-5

Soil Sample Results for PCBs Detected

Above Minimum Reporting Limits at CAS TA-19-002-TAB2

\begin{tabular}{|c|c|c|c|}
\hline \multirow{2}{*}{$\begin{array}{l}\text { Sample } \\
\text { Number }\end{array}$} & \multirow{2}{*}{$\begin{array}{l}\text { Sample } \\
\text { Location }\end{array}$} & \multirow{2}{*}{$\begin{array}{l}\text { Depth } \\
\text { (ft bgs) }\end{array}$} & \multirow{2}{*}{$\begin{array}{c}\text { Contaminants of Potential Concern }(\mu \mathrm{g} / \mathrm{kg}) \\
\text { Aroclor-1254 }\end{array}$} \\
\hline & & & \\
\hline \multicolumn{3}{|c|}{ Preliminary Action Levels ${ }^{a}$} & 1,000 \\
\hline 410B2009RR1 & East Sidewall & $2-3$ & 570 \\
\hline 410B2013 & East Sidewall & $2-3$ & 300 \\
\hline 410B2014 & Stockpile location & $0-0.5$ & 540 \\
\hline 410B2015 & Stockpile location & $0-0.5$ & 50 \\
\hline
\end{tabular}

aBased on U.S. Environmental Protection Agency, Region 9 Preliminary Remediation Goals (PRGs) (EPA, 2000b)

$\mathrm{ft}$ bgs $=$ Feet below ground surface $\mu \mathrm{g} / \mathrm{kg}=$ Micrograms per kilogram

\section{A.5.4.4 Isotopic Uranium}

The isotopic uranium results for soil samples collected from CAS TA-19-002-TAB2, which were detected above MRLs, are presented on Table A.5-6. Several samples had U-234, U-235, and U-238 concentrations exceeding the respective PALs. Uranium-234, U-235, and U-238 analytical results were evaluated using the normalized difference test as discussed in Section A.2.7, and the concentrations in samples 410B2002, 410B2003, 410B2008, 410B2011, and 410B2012 are considered indistinguishable from the PAL. Confirmation samples 410B2009, 410B2013, 410B2014, and 410B2021 have U-235 and U-238 concentrations considered distinguishable from the PAL. Samples 410B2009 and 410B2013 represent the eastern sidewall confirmation samples. Samples 410B2014 and 410B2021 represent the ground surface beneath the former DU-waste stockpile. See Section A.5.3.2 for details regarding additional soil removal and sampling.

Table A.5-7 shows the isotopic uranium results of an unknown solid material found within the boundaries of the metal pan object. This solid material (sample 410B2006) was submitted for analysis to confirm that DU was the COC for the soil/debris; therefore, it was expected to have concentrations exceeding PALs. 
Table A.5-6

Soil Sample Results for Isotopic Uranium

Detected Above Minimum Reporting Limits at CAS TA-19-002-TAB2

\begin{tabular}{|c|c|c|c|c|c|}
\hline \multirow{2}{*}{$\begin{array}{l}\text { Sample } \\
\text { Number }\end{array}$} & \multirow{2}{*}{$\begin{array}{l}\text { Sample } \\
\text { Location }\end{array}$} & \multirow{2}{*}{$\begin{array}{l}\text { Depth } \\
\text { (ft bgs) }\end{array}$} & \multicolumn{3}{|c|}{ Contaminants of Potential Concern (pCi/g) } \\
\hline & & & \multirow{2}{*}{$\begin{array}{c}\text { Uranium-234 } \\
3.47\end{array}$} & \multirow{2}{*}{$\begin{array}{c}\text { Uranium-235 } \\
0.07\end{array}$} & \multirow{2}{*}{$\begin{array}{c}\text { Uranium-238 } \\
3.47\end{array}$} \\
\hline \multicolumn{3}{|c|}{ Preliminary Action Levels ${ }^{a}$} & & & \\
\hline 410B2001 & $\begin{array}{c}\text { North Corner } \\
\text { Under Metal Tray }\end{array}$ & $2.5-3$ & $1.47 \pm 0.28$ & $0.071 \pm 0.025$ & $2.55 \pm 0.47$ \\
\hline 410B2002 & \multirow{2}{*}{$\begin{array}{c}\text { South Corner } \\
\text { Under Metal Tray }\end{array}$} & $2-2.5$ & $1.8 \pm 0.34$ & $0.0857 \pm 0.028$ & $5.66 \pm 1$ \\
\hline 410B2003 & & $2-2.5$ & $1.75 \pm 0.33$ & $0.0891 \pm 0.03$ & $5.76 \pm 1.1$ \\
\hline 410B2007 & West Sidewall & $2-3$ & $1.22 \pm 0.20$ & -- & $1.92 \pm 0.29$ \\
\hline 410B2008 & North Sidewall & $2-3$ & $1.72 \pm 0.27$ & $0.096 \pm 0.042$ & $4.18 \pm 0.59$ \\
\hline 410B2009 & East Sidewall & $2-3$ & $4.38 \pm 0.65$ & $0.41 \pm 0.11$ & $26 \pm 3.5$ \\
\hline 410B2010 & South Sidewall & $2-3$ & $1.31 \pm 0.22$ & $0.064 \pm 0.034$ & $1.74 \pm 0.28$ \\
\hline 410B2011 & Floor Southend & $2-3$ & $1.37 \pm 0.22$ & $0.12 \pm 0.046$ & $2.9 \pm 0.43$ \\
\hline 410B2012 & Floor Northend & $2-3$ & $2.11 \pm 0.32$ & $0.135 \pm 0.049$ & $5.61 \pm 0.78$ \\
\hline 410B2013 & East Sidewall & $2-3$ & $2.23 \pm 0.35$ & $0.279 \pm 0.082$ & $11 \pm 1.5$ \\
\hline 410B2014 & Stockpile location & $0-0.5$ & $2.36 \pm 0.37$ & $0.201 \pm 0.070$ & $10.2 \pm 1.4$ \\
\hline 410B2015 & Stockpile location & $0-0.5$ & $1.34 \pm 0.24$ & $0.119 \pm 0.052$ & $2.62 \pm 0.41$ \\
\hline 410B2016 & Stockpile location & $0-0.5$ & $1.21 \pm 0.23$ & $0.067 \pm 0.036$ & $1.99 \pm 0.36$ \\
\hline 410B2017 & Stockpile location & $0-0.5$ & $1.38 \pm 0.26$ & $0.16 \pm 0.057$ & $4.04 \pm 0.68$ \\
\hline 410B2018 & Stockpile location & $0-0.5$ & $1.05 \pm 0.2$ & $0.042 \pm 0.026$ & $1.14 \pm 0.22$ \\
\hline 410B2019 & Stockpile location & $0-0.5$ & $1.14 \pm 0.22$ & $0.078 \pm 0.039$ & $1.45 \pm 0.27$ \\
\hline 410B2020 & Stockpile location & $0-0.5$ & $0.97 \pm 0.19$ & $0.132 \pm 0.051$ & $1.14 \pm 0.22$ \\
\hline $410 B 2021$ & Stockpile location & $0-0.5$ & $2.28 \pm 0.4$ & $0.207 \pm 0.067$ & $10.1 \pm 1.6$ \\
\hline 410B2022 & Stockpile location & $0-0.5$ & $1.26 \pm 0.24$ & $0.086 \pm 0.042$ & $1.41 \pm 0.26$ \\
\hline $410 B 2023$ & Stockpile location & $0-0.5$ & $1.12 \pm 0.21$ & -- & $1.2 \pm 0.23$ \\
\hline 410B2024 & $\begin{array}{l}\text { East Sidewall/ } \\
\text { Stockpile }\end{array}$ & $0-0.5$ & $1.41 \pm 0.26$ & $0.084 \pm 0.039$ & $2.23 \pm 0.39$ \\
\hline 410B2034 & Stockpile location & $0-0.5$ & $1.13 \pm 0.20$ & $0.067 \pm 0.030$ & $1.16 \pm 0.21$ \\
\hline
\end{tabular}

a'Based on background concentration listed in Environmental Monitoring Report for the Proposed Ward Valley, California, Low-Level Radioactive Waste (LLRW) Facility (US Ecology and Atlan-Tech, 1991)

$\mathrm{ft}$ bgs $=$ Feet below ground surface

$\mathrm{pCi} / \mathrm{g}=$ Picocuries per gram

-- = Not detected above minimum reporting limits 
Table A.5-7

Solid Sample Results Detected Above

Minimum Reporting Limits at CAS TA-19-002-TAB2

\begin{tabular}{||c|c|c|c|c|c|}
\hline $\begin{array}{c}\text { Sample } \\
\text { Number }\end{array}$ & $\begin{array}{c}\text { Sample } \\
\text { Matrix }\end{array}$ & Parameter & Results & Units & PALs \\
\hline \hline 410B2006 & Solid & Uranium-234 & $115 \pm 50(\mathrm{~J})^{\mathrm{a}}$ & $\mathrm{pCi} / \mathrm{g}$ & $3.47^{\mathrm{c}}$ \\
\hline 410B2006 & Solid & Uranium-235 & $24 \pm 13(\mathrm{~J})^{\mathrm{a}}$ & $\mathrm{pCi} / \mathrm{g}$ & $0.07^{\mathrm{c}}$ \\
\hline 410B2006 & Solid & Uranium-238 & $830 \pm 350(\mathrm{~J})^{\mathrm{a}}$ & $\mathrm{pCi} / \mathrm{g}$ & $3.47^{\mathrm{c}}$ \\
\hline 410B2006 & Solid & Actinium-228 & $1.25 \pm 0.25$ & $\mathrm{pCi} / \mathrm{g}$ & $3.64^{\mathrm{c}}$ \\
\hline 410B2006 & Solid & Bismuth-214 & $1.39 \pm 0.26$ & $\mathrm{pCi} / \mathrm{g}$ & $3.47^{\mathrm{c}}$ \\
\hline 410B2006 & Solid & Potassium-40 & $9.7 \pm 1.8$ & $\mathrm{pCi} / \mathrm{g}$ & $30.7^{\mathrm{d}}$ \\
\hline 410B2006 & Solid & Lead-212 & $1.28 \pm 0.23$ & $\mathrm{pCi/g}$ & $3.64^{\mathrm{c}}$ \\
\hline 410B2006 & Solid & Lead-214 & $1.46 \pm 0.26$ & $\mathrm{pCi} / \mathrm{g}$ & $3.47^{\mathrm{c}}$ \\
\hline 410B2006 & Solid & Thorium-234 & $630 \pm 100(\mathrm{~J})^{\mathrm{b}}$ & $\mathrm{pCi/g}$ & $3.47^{\mathrm{c}}$ \\
\hline 410B2006 & Solid & Thallium-208 & $0.346 \pm 0.077$ & $\mathrm{pCi} / \mathrm{g}$ & $3.38^{\mathrm{c}}$ \\
\hline 410B2006 & Solid & Uranium-235 & $8.6 \pm 1.4(\mathrm{~J})^{\mathrm{b}}$ & $\mathrm{pCi} / \mathrm{g}$ & $0.07^{\mathrm{c}}$ \\
\hline
\end{tabular}

${ }^{a}$ Qualifier added to laboratory data; record accepted. Chemical yield below control limits.

${ }^{b}$ Qualifier added to laboratory data; record accepted. Samples do not meet counting geometry requirements.

${ }^{\mathrm{C}}$ Based on background concentration reported in Environmental Monitoring Report for the Proposed

Ward Valley, California, Low-Level Radioactive Waste (LLRW) Facility (US Ecology and Atlan-Tech, 1991)

${ }^{\mathrm{d}}$ Based on background concentration listed or derived in Off-Site Radiation Exposure Review

Project, Phase II Soil Program (McArthur and Miller, 1989)

$\mathrm{pCi} / \mathrm{g}=$ Picocuries per gram

$\mathrm{J}=$ Estimated value

\section{A.5.4.5 Gamma-Emitting Radionuclides}

The gamma-emitting radionuclides results for soil samples collected from CAS TA-19-002-TAB2, which were detected above MRLs, are presented on Table A.5-8. Except for thorium-234 and potassium-40, all gamma-emitting radionuclide results were below PALs (NNSA/NV, 2002a). Thorium-234 and potassium-40 were detected at concentrations exceeding and/or equal to the PALs; however, thorium-234 and potassium-40 analytical results were evaluated using the normalized difference test as discussed in Section A.2.7. The thorium-234 and potassium-40 concentrations are considered indistinguishable from the PAL, except for the thorium-234 concentration for 410B2009 which is considered statistically above the PAL. 
Table A.5-8

Soil Sample Results for Gamma-Emitting Radionuclides Detected Above Minimum Reporting Limits at CAS TA-19-002-TAB2

(Page 1 of 2)

\begin{tabular}{|c|c|c|c|c|c|c|c|c|c|c|c|c|}
\hline \multirow[b]{2}{*}{$\begin{array}{l}\text { Sample } \\
\text { Number }\end{array}$} & \multirow[b]{2}{*}{$\begin{array}{l}\text { Sample } \\
\text { Location }\end{array}$} & \multirow[b]{2}{*}{$\begin{array}{l}\text { Depth } \\
\text { (ft bgs) }\end{array}$} & \multicolumn{10}{|c|}{ Contaminants of Potential Concern (pCi/g) } \\
\hline & & & 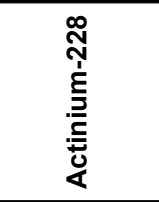 & 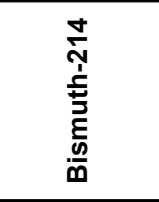 & 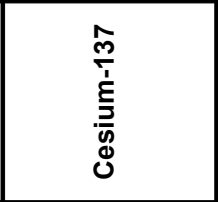 & $\begin{array}{l}\stackrel{N}{N} \\
\frac{1}{0} \\
\stackrel{d}{J}\end{array}$ & 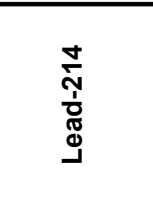 & 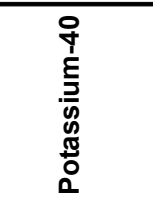 & 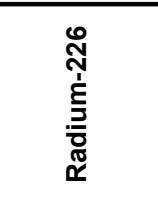 & 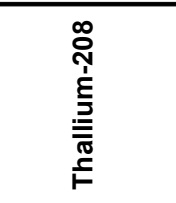 & 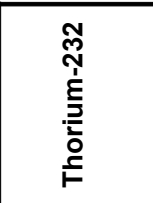 & 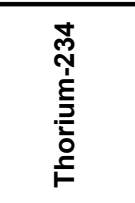 \\
\hline \multicolumn{3}{|c|}{ Preliminary Action Levels } & $3.64^{a}$ & $3.47^{a}$ & $7^{\mathrm{b}}$ & $3.64^{a}$ & $3.47^{a}$ & $30.7^{b}$ & $3.47^{a}$ & $3.38^{a}$ & $3.64^{a}$ & $3.47^{a}$ \\
\hline 410B2001 & $\begin{array}{c}\text { North Corner } \\
\text { Under Metal } \\
\text { Tray }\end{array}$ & $2.5-3$ & $1.59 \pm 0.38$ & -- & -- & $1.53 \pm 0.29$ & $1.27 \pm 0.27$ & $27.5 \pm 4.1$ & -- & -- & $2.02 \pm 0.64$ & -- \\
\hline 410B2002 & \multirow{2}{*}{$\begin{array}{c}\text { South } \\
\text { Corner } \\
\text { Under Metal } \\
\text { Tray }\end{array}$} & $2-2.5$ & $1.87 \pm 0.45$ & $1.44 \pm 0.65$ & -- & $1.53 \pm 0.3$ & $1.49 \pm 0.31$ & $28.7 \pm 4.2$ & $1.46 \pm 0.27$ & $0.698 \pm 0.14$ & $2.04 \pm 0.72$ & -- \\
\hline 410B2003 & & $2-2.5$ & -- & -- & -- & $2.15 \pm 0.5$ & $1.21 \pm 0.32$ & $30.7 \pm 4.4$ & -- & -- & $1.6 \pm 0.66$ & -- \\
\hline 410B2004 & $\begin{array}{c}\text { Thirty Ft } \\
\text { West of } \\
\text { Debris Pile }\end{array}$ & $0-0.5$ & $2.05 \pm 0.42$ & -- & -- & $1.73 \pm 0.31$ & $1.46 \pm 0.28$ & $26.1 \pm 3.9$ & -- & $0.58 \pm 0.14$ & $1.67 \pm 0.54$ & -- \\
\hline 410B2005 & $\begin{array}{l}\text { Near West } \\
\text { Corner of } \\
\text { Metal Tray }\end{array}$ & $0-0.5$ & -- & -- & $0.392 \pm 0.14(\mathrm{~J})$ & $1.91 \pm 0.37$ & $1.77 \pm 0.36$ & $28.6 \pm 4.4$ & -- & -- & $1.77 \pm 0.91$ & -- \\
\hline 410B2007 & $\begin{array}{c}\text { West } \\
\text { Sidewall }\end{array}$ & $2-3$ & $1.75 \pm 0.41$ & $1.02 \pm 0.25$ & -- & $1.74 \pm 0.34$ & $1.11 \pm 0.25$ & $27.7 \pm 5.2$ & -- & $0.48 \pm 0.13$ & -- & -- \\
\hline 410B2008 & $\begin{array}{l}\text { North } \\
\text { Sidewall }\end{array}$ & $2-3$ & $1.72 \pm 0.43$ & $0.98 \pm 0.27$ & -- & $1.79 \pm 0.36$ & $1.14 \pm 0.26$ & $28 \pm 5.4$ & -- & $0.59 \pm 0.15$ & -- & $5 \pm 1.9$ \\
\hline 410B2009 & $\begin{array}{c}\text { East } \\
\text { Sidewall }\end{array}$ & $2-3$ & $1.69 \pm 0.39$ & $1.12 \pm 0.27$ & -- & $1.68 \pm 0.34$ & $1.25 \pm 0.27$ & $26.3 \pm 5.0$ & -- & $0.54 \pm 0.14$ & -- & $20.4 \pm 4.0$ \\
\hline 410B2010 & $\begin{array}{l}\text { South } \\
\text { Sidewall }\end{array}$ & $2-3$ & $1.25 \pm 0.35$ & $0.89 \pm 0.25$ & -- & $1.7 \pm 0.34$ & $1.08 \pm 0.25$ & $26.4 \pm 5.2$ & -- & $0.57 \pm 0.15$ & -- & -- \\
\hline
\end{tabular}


Table A.5-8

Soil Sample Results for Gamma-Emitting Radionuclides Detected Above Minimum Reporting Limits at CAS TA-19-002-TAB2

(Page 2 of 2)

\begin{tabular}{|c|c|c|c|c|c|c|c|c|c|c|c|c|}
\hline \multirow[b]{2}{*}{$\begin{array}{l}\text { Sample } \\
\text { Number }\end{array}$} & \multirow[b]{2}{*}{$\begin{array}{c}\text { Sample } \\
\text { Location }\end{array}$} & \multirow[b]{2}{*}{$\begin{array}{l}\text { Depth } \\
\text { (ft bgs) }\end{array}$} & \multicolumn{10}{|c|}{ Contaminants of Potential Concern (pCi/g) } \\
\hline & & & 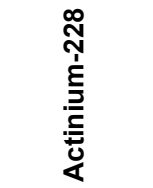 & 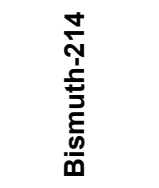 & 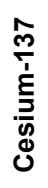 & 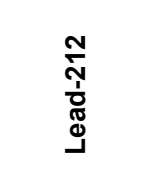 & 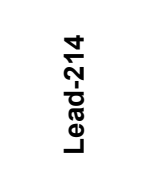 & 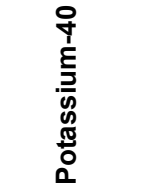 & 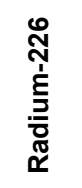 & 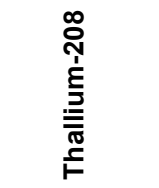 & 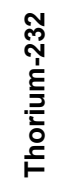 & 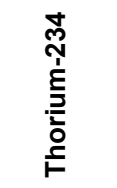 \\
\hline \multicolumn{3}{|c|}{ Preliminary Action Levels } & $3.64^{a}$ & $3.47^{a}$ & $7^{b}$ & $3.64^{a}$ & $3.47^{a}$ & $30.7^{b}$ & $3.47^{a}$ & $3.38^{a}$ & $3.64^{a}$ & $3.47^{a}$ \\
\hline 410B2011 & $\begin{array}{c}\text { Floor } \\
\text { Southend }\end{array}$ & $2-3$ & $1.56 \pm 0.37$ & $0.96 \pm 0.25$ & -- & $1.53 \pm 0.31$ & $1.1 \pm 0.24$ & $26.4 \pm 5.0$ & -- & $0.61 \pm 0.15$ & -- & -- \\
\hline 410B2012 & $\begin{array}{c}\text { Floor } \\
\text { Northend }\end{array}$ & $2-3$ & $1.33 \pm 0.41$ & $0.96 \pm 0.28$ & -- & $1.73 \pm 0.36$ & $1.24 \pm 0.28$ & $24.9 \pm 5.0$ & -- & $0.53 \pm 0.15$ & -- & $6.6 \pm 2.0$ \\
\hline
\end{tabular}

aBased on background concentrations reported in Environmental Monitoring Report for the Proposed Ward Valley, California, Low-Level Radioactive Waste (LLRW) Facility (US Ecology and Atlan-Tech, 1991)

${ }^{6}$ Based on background concentration listed or derived in Off-Site Radiation Exposure Review Project, Phase II Soil Program (McArthur and Miller, 1989)

$\mathrm{ft}$ bgs $=$ Feet below ground surface

$\mathrm{pCi} / \mathrm{g}=$ Picocuries per gram

- = Not detected above minimum reporting limits 


\section{A.5.5 Contaminants of Concern}

Analytical results of the unknown solid material and FSRs confirmed the presence of DU within the buried soil and debris of CAS TA-19-002-TAB2. No other COCs were identified. A detection of PCBs (Aroclor-1254) was identified; however, it was below PALs and therefore not considered a COC. Based on the analytical results from final verification samples, there are no COCs identified in remaining soil.

\section{A.5.6 Nature and Extent of Contamination}

Investigation results indicate that DU contamination was primarily confined to the interior of the metal pan object. The vertical and lateral extent of DU contamination was delineated following the excavation, removal, and segregation of the soil, debris, and metal pan from the subsurface. Analytical results from confirmation samples collected from the floor and sidewalls of the excavation following the removal of the metal pan, as well as the verification samples collected from the former stockpile area, indicate there are no COCs remaining at this site.

\section{A.5.7 Revised Conceptual Site Model}

No variations to the CSM were identified. 


\section{A.6.0 CAS TA-21-002-TAAL, Disposal Trench (Antelope Lake)}

This CAS is located in the southwestern corner of Antelope Lake on the playa and adjacent to the start of vegetation. Prior to the investigation, the site dimension was given as $880 \mathrm{ft}$ in diameter (based on disturbed soils) and included a soil mound on the eastern end of the site. There was miscellaneous debris scattered throughout the site, including wood, metal, and UXO. Geophysical surveys identified four areas of subsurface debris; although, there was no obvious trench configuration visible from the surface.

Prior to intrusive activities, UXO personnel performed an avoidance survey around the CAS footprint to identify any potential UXO and mark out the work area to protect the health and safety of workers.

\section{A.6.1 Corrective Action Investigation}

A total of 26 environmental soil samples were collected by hand or backhoe and submitted for laboratory analyses. In addition, three QC field duplicates, two QC field blanks, one QC equipment rinsate blank, one source blank, and eight QC trip blanks were collected and submitted for laboratory analysis. A list of the samples collected and the parameters analyzed for are presented Table A.6-1.

Table A.6-1 also provides sample information on the 23 waste management soil samples collected and submitted for analysis. Although presented in this table for completeness, discussion regarding sample collection and the waste management analytical results are provided in Appendix D.

\section{A.6.2 CAIP Implementation}

The following CAI activities were performed to meet the CAIP requirements:

- Excavated within the footprint of the geophysical anomaly to identify nature and extent of buried materials

- Field screened soils for alpha and beta/gamma radiation and HEs

- Collected subsurface samples at the native soil interface beneath debris

- Collected multiple confirmation samples from the excavation

- Segregated and separated soil, debris, and UXO for proper waste disposal

- Conducted waste characterization sampling for waste profiles

- Disposed of all IDW from the site including the demilitarization of potentially live ordnance

- Collected verification soil samples following disposal of the DU-contaminated stockpile

- Backfilled the excavation with clean fill 
Table A.6-1

Samples Collected for CAS TA-21-002-TAAL, Disposal Trench

(Page 1 of 3 )

\begin{tabular}{|c|c|c|c|c|c|c|}
\hline $\begin{array}{l}\text { Sample } \\
\text { Number }\end{array}$ & $\begin{array}{c}\text { Sample } \\
\text { Collection } \\
\text { Date }\end{array}$ & $\begin{array}{c}\text { Sample } \\
\text { Location }\end{array}$ & $\begin{array}{l}\text { Depth } \\
\text { (ft bgs) }\end{array}$ & $\begin{array}{l}\text { Sample } \\
\text { Matrix }\end{array}$ & Purpose & Analyses \\
\hline 410AL001 & $11 / 4 / 2002$ & $\begin{array}{c}\text { East End } \\
\text { of Trench \#2 }\end{array}$ & $5.5-6$ & Soil & SC & Set 2 \\
\hline 410AL002 & \multirow[b]{2}{*}{$11 / 5 / 2002$} & \multirow{2}{*}{$\begin{array}{l}\text { West End } \\
\text { of Trench \#3 }\end{array}$} & $7.5-8$ & Soil & $\mathrm{SC}$ & Set 2 \\
\hline 410AL003 & & & $7.5-8$ & Soil & $\begin{array}{c}\text { Field Duplicate of } \\
\quad \# 410 A L 002\end{array}$ & Set 2 \\
\hline 410AL004 & \multirow{5}{*}{$3 / 13 / 2003$} & East Sidewall & $6-7$ & Soil & Confirmation & Set 2 \\
\hline 410AL005 & & Floor - Southend & $6-7$ & Soil & Confirmation & Set 2 \\
\hline 410AL006 & & West Sidewall & $6-7$ & Soil & Confirmation & Set 2 \\
\hline 410AL007 & & \multirow{2}{*}{ South Sidewall } & $6-7$ & Soil & Confirmation & Set 2 \\
\hline 410AL008 & & & $6-7$ & Soil & Confirmation & Set 2 \\
\hline 410AL009 & \multirow{2}{*}{$3 / 15 / 2003$} & \multirow{2}{*}{ Floor Northend } & $10-11$ & Soil & Confirmation & Set 2 \\
\hline 410AL010 & & & $10-11$ & Soil & Confirmation & Set 2 \\
\hline 410AL011 & \multirow{3}{*}{$3 / 16 / 2003$} & \multirow[b]{2}{*}{ North Sidewall } & $10-11$ & Soil & Confirmation & Set 2 \\
\hline 410AL012 & & & $10-11$ & Soil & $\begin{array}{l}\text { Field Duplicate of } \\
\quad \# 410 A L 011\end{array}$ & Set 2 \\
\hline 410AL013 & & East Sidewall & $10-11$ & Soil & $\begin{array}{l}\text { Confirmation, } \\
\text { Lab QC }\end{array}$ & Set 2 \\
\hline 410AL014 & \multirow{3}{*}{$3 / 20 / 2003$} & West Sidewall & 3 & Soil & Confirmation & Set 2 \\
\hline 410AL015 & & Floor Northend & $10-11$ & Soil & Confirmation & Set 2 \\
\hline 410AL016 & & North Sidewall & $10-11$ & Soil & Confirmation & Set 2 \\
\hline 410AL017 & $9 / 11 / 2003$ & Stockpile location & $0-0.5$ & Soil & Confirmation & Isotopic uranium \\
\hline 410AL018 & $9 / 11 / 2003$ & Stockpile location & $0-0.5$ & Soil & Confirmation & Isotopic uranium \\
\hline 410AL019 & $9 / 11 / 2003$ & Stockpile location & $0-0.5$ & Soil & Confirmation & Isotopic uranium \\
\hline 410AL020 & $9 / 11 / 2003$ & Stockpile location & $0-0.5$ & Soil & Confirmation & Isotopic uranium \\
\hline 410AL021 & \multirow{9}{*}{$10 / 14 / 2003$} & Stockpile location & $0-0.5$ & Soil & Confirmation & Isotopic uranium \\
\hline 410AL022 & & Stockpile location & $0-0.5$ & Soil & Confirmation & Isotopic uranium \\
\hline 410AL023 & & Stockpile location & $0-0.5$ & Soil & Confirmation & Isotopic uranium \\
\hline 410AL024 & & Stockpile location & $0-0.5$ & Soil & Confirmation & Isotopic uranium \\
\hline 410AL025 & & Stockpile location & $0-0.5$ & Soil & Confirmation & Isotopic uranium \\
\hline 410AL026 & & Stockpile location & $0-0.5$ & Soil & Confirmation & Isotopic uranium \\
\hline 410AL027 & & Stockpile location & $0-0.5$ & Soil & Confirmation & Isotopic uranium \\
\hline 410AL028 & & Stockpile location & $0-0.5$ & Soil & Confirmation & Isotopic uranium \\
\hline 410AL029 & & Stockpile location & $0-0.5$ & Soil & $\begin{array}{c}\text { Field Duplicate of } \\
\quad \# 410 A L 028\end{array}$ & Isotopic uranium \\
\hline
\end{tabular}


Table A.6-1

Samples Collected for CAS TA-21-002-TAAL, Disposal Trench

(Page 2 of 3 )

\begin{tabular}{|c|c|c|c|c|c|c|}
\hline $\begin{array}{l}\text { Sample } \\
\text { Number }\end{array}$ & $\begin{array}{c}\text { Sample } \\
\text { Collection } \\
\text { Date }\end{array}$ & $\begin{array}{l}\text { Sample } \\
\text { Location }\end{array}$ & $\begin{array}{c}\text { Depth } \\
\text { (ft bgs) }\end{array}$ & $\begin{array}{c}\text { Sample } \\
\text { Matrix }\end{array}$ & Purpose & Analyses \\
\hline 410AL301 & $\overline{111 / 4 / 2002}$ & $\overline{\overline{\mathrm{NA}}}$ & $\overline{\overline{\mathrm{NA}}}$ & $\overline{\overline{\text { Water }}}$ & $\overline{\text { Trip Blank }}$ & 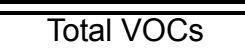 \\
\hline 410AL302 & $11 / 5 / 2002$ & $\overline{N A}$ & NA & Water & Field Blank & Set 2 \\
\hline 410AL303 & \multirow{2}{*}{$3 / 13 / 2003$} & $\overline{\mathrm{NA}}$ & $\overline{\mathrm{NA}}$ & Water & Trip Blank & Total VOCs \\
\hline 410AL304 & & $\overline{N A}$ & $\overline{N A}$ & Water & Source Blank & Set 5 \\
\hline 410AL305 & $3 / 15 / 2003$ & $\overline{N A}$ & $\overline{\mathrm{NA}}$ & Water & Trip Blank & Total VOCs \\
\hline 410AL306 & \multirow{3}{*}{$3 / 16 / 2003$} & NA & NA & Water & $\begin{array}{c}\text { Equipment } \\
\text { Rinsate Blank }\end{array}$ & Set 5 \\
\hline 410AL307 & & $\mathrm{NA}$ & NA & Water & Trip Blank & Total VOCs \\
\hline 410AL308 & & $\overline{N A}$ & NA & Water & Trip Blank & Total VOCs \\
\hline 410AL309 & $3 / 20 / 2003$ & $\overline{N A}$ & $\overline{N A}$ & Water & Trip Blank & Total VOCs \\
\hline 410AL310 & $3 / 25 / 2003$ & $\overline{\mathrm{NA}}$ & $\overline{\mathrm{NA}}$ & Water & Trip Blank & Total VOCs \\
\hline 410AL311 & $3 / 26 / 2003$ & $\overline{N A}$ & $\overline{N A}$ & Water & Trip Blank & Total VOCs \\
\hline 410AL312 & $10 / 14 / 2003$ & Stockpile location & $\overline{N A}$ & Water & Field Blank & Isotopic uranium \\
\hline 410AL501 & \multirow{10}{*}{$3 / 25 / 2003$} & $\overline{\mathrm{NA}}$ & NA & Soil & $\overline{\text { WM }}$ & Set 2 \\
\hline 410AL502 & & $\overline{N A}$ & NA & Soil & WM & Set 2 \\
\hline 410AL503 & & $\overline{N A}$ & NA & Soil & WM & Set 5 \\
\hline 410AL504 & & $\overline{N A}$ & NA & Soil & WM & Set 2 \\
\hline 410AL505 & & $\overline{N A}$ & NA & Soil & WM & Set 5 \\
\hline 410AL506 & & $\overline{N A}$ & $\overline{N A}$ & Soil & WM & Set 2 \\
\hline 410AL507 & & $\overline{N A}$ & $\overline{N A}$ & Soil & WM & Set 5 \\
\hline 410AL508 & & $\overline{N A}$ & $\overline{N A}$ & Soil & WM & Set 2 \\
\hline 410AL509 & & $\overline{N A}$ & $\overline{N A}$ & Soil & WM & Set 2 \\
\hline 410AL510 & & NA & NA & Soil & WM & Set 2 \\
\hline 410AL511 & \multirow{9}{*}{$3 / 25 / 2003$} & $\overline{N A}$ & $\overline{N A}$ & Soil & WM & Set 2 \\
\hline 410AL512 & & $\overline{N A}$ & NA & Soil & WM & Set 2 \\
\hline 410AL513 & & NA & NA & Soil & WM & Set 5 \\
\hline 410AL514 & & $\overline{N A}$ & NA & Soil & WM & Set 2 \\
\hline 410AL515 & & NA & NA & Soil & WM & Set 2 \\
\hline 410AL516 & & $\overline{N A}$ & NA & Soil & WM & Set 2 \\
\hline 410AL517 & & $\mathrm{NA}$ & $\overline{N A}$ & Soil & WM & Set 5 \\
\hline 410AL518 & & $\overline{N A}$ & NA & Soil & WM & Set 2 \\
\hline 410AL519 & & NA & NA & Soil & $\overline{\text { WM }}$ & Set 2 \\
\hline
\end{tabular}


Table A.6-1

Samples Collected for CAS TA-21-002-TAAL, Disposal Trench

(Page 3 of 3 )

\begin{tabular}{||c|c|c|c|c|c|c||}
\hline $\begin{array}{c}\text { Sample } \\
\text { Number }\end{array}$ & $\begin{array}{c}\text { Sample } \\
\text { Collection } \\
\text { Date }\end{array}$ & $\begin{array}{c}\text { Sample } \\
\text { Location }\end{array}$ & $\begin{array}{c}\text { Depth } \\
\text { (ft bgs) }\end{array}$ & $\begin{array}{c}\text { Sample } \\
\text { Matrix }\end{array}$ & Purpose & Analyses \\
\hline \hline 410AL520 & $3 / 26 / 2003$ & NA & NA & Soil & WM & Set 2 \\
\cline { 1 - 5 } & 410AL521 & NA & NA & Soil & WM & Set 5 \\
\hline 4 410AL522 & $10 / 14 / 2003$ & NA & NA & Soil & WM & Isotopic uranium \\
\hline
\end{tabular}

Set 2 = Total VOCs, Total SVOCs, Total RCRA Metals, High Explosives, Total Beryllium, Gamma Spectrometry, TPH (DRO-GRO), Isotopic Uranium, and Isotopic Plutonium

Set 5 = Total VOCs, Total SVOCs, Total RCRA Metals, High Explosives, Total Beryllium, Gamma Spectrometry, TPH (DRO-GRO), Isotopic Uranium, Isotopic Plutonium, PCBs, Pesticides, and Herbicides

$\mathrm{SC}=$ Site characterization

$\mathrm{NA}=$ Not applicable

$\mathrm{QC}=$ Quality control

$\mathrm{WM}=$ Waste management

$\mathrm{ft}$ bgs $=$ Feet below ground surface

\section{A.6.2.1 Deviations}

During the initial CAU investigation activities conducted in October and November 2002, the excavation activities did not define the horizontal and vertical extent of the debris due to the nature of the materials and the capability of the equipment. The buried debris, which consisted of a variety of material including metallic debris, UXO, and steel wire, was greater in vertical and lateral extent than previously thought. At the completion of this initial phase, two soil samples (410AL001 and 410AL002) were collected from the southern and northern trenches and submitted for analysis.

It was proposed in ROTC No. 2 to the CAIP that additional excavation be completed as a supplemental field activity to the CAIP/DQO process and to include the excavation, segregation, and separation of soil, debris, and UXO. These additional excavation activities commenced on March 11, 2003, and were completed on March 20, 2003. During these excavation activities, the soils in the excavation were field screened for RDX. The FSRs indicated that RDX was not above the FSLs in the soils. Therefore, the limits of the excavation were defined by the presence of UXO, as well as the presence of DU in soil and debris. Based on the historical data review for the CAIP, it was not anticipated that DU would be present at CAS TA-21-002-TAAL. Further segregation of the soils and debris from the DU-impacted material was implemented. 


\section{A.6.3 Investigation Activities}

The following sections provide CAS-specific details of excavation, field screening, and sample collection and analysis. The various phases of the initial and supplemental activities for

CAS TA-21-002-TAAL are summarized in Table A.6-2.

Table A.6-2

Summary of Excavation Activities at CAS TA-21-002-TAAL

\begin{tabular}{|c|c|}
\hline Date of Activities & Activity Summary \\
\hline November 4 to 5,2002 & $\begin{array}{l}\text { Three trenches excavated and/or potholed within the geophysical anomaly and confirmed debris and } \\
\text { UXO are present in subsurface. Samples } 410 A L 001 \text { to } 410 A L 003 \text { were collected for characterization. }\end{array}$ \\
\hline March 11 to 16,2003 & $\begin{array}{l}\text { Supplemental field activities started with excavation of soil, debris, and UXO from the subsurface. All } \\
\text { IDW was segregated and stockpiled. Confirmation samples } 410 A L 004 \text { to } 410 A L 013 \text { were collected } \\
\text { from the sidewalls and floor of portions of completed excavation. On March 16, DU contamination } \\
\text { was encountered and work suspended for health and safety reasons. }\end{array}$ \\
\hline March 19 and 20, 2003 & $\begin{array}{l}\text { Actives were resumed under an RWP and the excavation of all debris and UXO was completed. } \\
\text { Confirmation samples } 410 \text { AL } 013 \text { to } 410 \text { AL } 016 \text { were collected from remaining sidewalls and floor of } \\
\text { completed excavation. }\end{array}$ \\
\hline March 25 and 26, 2003 & A total of 21 waste characterization samples were collected from the soil stockpiles. \\
\hline April 24 to July 17,2003 & Five separate episodes of UXO demilitarization activities were conducted (see Appendix D). \\
\hline September 11, 2003 & $\begin{array}{l}\text { The last UXO demilitarization activity was conducted. Verification samples } 410 A L 017 \text { to } 410 A L 020 \\
\text { were collected from the former DU-stockpile staging areas. Results from sample } 410 A L 018 \text { indicated } \\
\text { that DU-contamination was still present above PALs. }\end{array}$ \\
\hline October 14, 2003 & $\begin{array}{l}\text { Additional soil was removed from the former DU-stockpile staging areas based on 410AL018. Nine } \\
\text { additional verification samples (410AL021 to 410AL029) were collected and results indicate } \\
\text { remaining soil is below PALs. } \\
\text { Summary: All soils associated with uranium results above PALs from the former stockpile areas } \\
\text { have been excavated and removed for disposal and the most recent verification samples indicate } \\
\text { remaining soil is below PALs. }\end{array}$ \\
\hline
\end{tabular}

\section{A.6.3.1 Field Screening}

Field screening was performed as specified in the CAIP (NNSA/NV, 2002a). Samples were field screened for alpha and beta/gamma-emitting radionuclides and HEs. Established FSLs were used to guide sample collection, guide excavation activities, and provide a basis for the selection of additional environmental samples for laboratory analyses. High explosives field screening was performed on soil collected from within the excavation and from stockpiled soil. All FSRs were below established FSLs for HE.

Radiological field screening was conducted throughout the investigation on soil and solid materials whenever UXO personnel would stop excavation activities and allow nonessential personnel within the exclusion zone. All FSRs were below FSLs until DU contamination was encountered on the 
north sidewall of the excavation at which time field-screening intervals were increased during the UXO excavation activities to delineate lateral and vertical contamination. Radiological field screening and surveys were performed on solid materials for waste management purposes. All confirmation samples collected from the floor and sidewalls of the excavation had FSRs below the FSLs.

\section{A.6.3.2 Excavation}

Due to safety concerns for potential UXO hazards within the disposal trench, only essential personnel were allowed within the established EZ (approximate 4,000-ft radius) and all excavation activities were performed by qualified UXO personnel. A backhoe was used to excavate small lifts of material for inspections by UXO personnel. If UXO was identified, it was segregated from soil and debris. During the CAU investigation activities conducted on November 4 and 5, 2002, the initial excavation of three trenches confirmed the presence of subsurface debris and ordnance within the footprint of the geophysical anomaly. The buried debris consisted of a variety of material including metallic debris, UXO, plastic, wood, and cables (Figure A.6-1). Initial field screening for HE indicated FSRs below the FSLs. Due the nature and size of the materials and UXO encountered, the vertical and lateral extent of potential contamination could not be determined. All UXO and noncontaminated scrap debris were temporarily stockpiled within a soil berm for future disposal and excavations were backfilled pending supplemental field activities to fully characterize the subsurface soil.

In accordance with ROTC No. 2 to the CAIP, which outlines the proposed excavation, segregation, and separation of soil, debris, and UXO, further excavation activities were completed as a supplemental field activity to further define and delineate the nature and extent of potential contamination. These additional excavation activities commenced on March 11, 2003, and were completed on March 20, 2003. Excavation activities started near the initial southern trench previously excavated in November 2002. This location correlates with the southern boundary of the geophysical anomaly. During these excavation activities, HE and radiological field screening was performed on the soils within the excavation. Because FSRs indicated that soil was not above the FSLs, excavation was guided by the presence of UXO and/or debris. As the excavation progressed northward based on the presence of debris and UXO, DU contamination was 


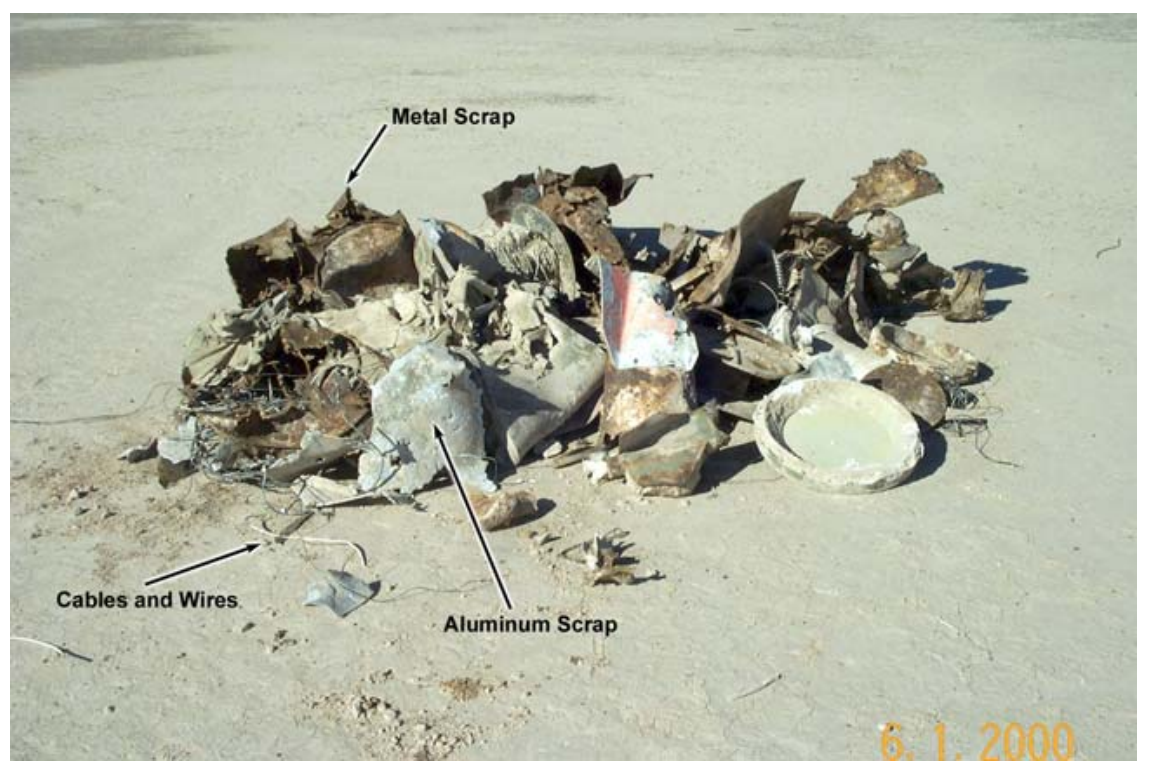

Figure A.6-1

\section{Antelope Lake Debris}

(Scrap debris typical of trench contents, photo taken November 2002)

encountered on subsurface soil and debris located in the central to western portion of the existing north wall. The detection of DU warranted further segregation of the soils and debris to separate out the DU-impacted material. To delineate the extent of DU contamination, the excavation activities continued northward until FSRs indicated that remaining soil and debris in the subsurface was below radiological FSLs.

As the excavation progressed, soil confirmation samples (410AL004 through 410AL016) were collected from the floor and sidewalls. These samples confirmed that the lateral and vertical extent of contamination within the disposal trench was delineated and that further excavation was not warranted. The confirmation sampling locations are presented on Figure A.6-2. The sample locations are field-located measurements relative to the sidewalls and center berm due to safety concerns on collecting GPS points within the excavation. Figure A.6-3 shows the historical disposal trench following excavation/characterization activities prior to backfilling.

Initial surface verification samples collected in September 2003 from the former DU-waste stockpile staging areas indicated concentrations of DU above the PAL remained 


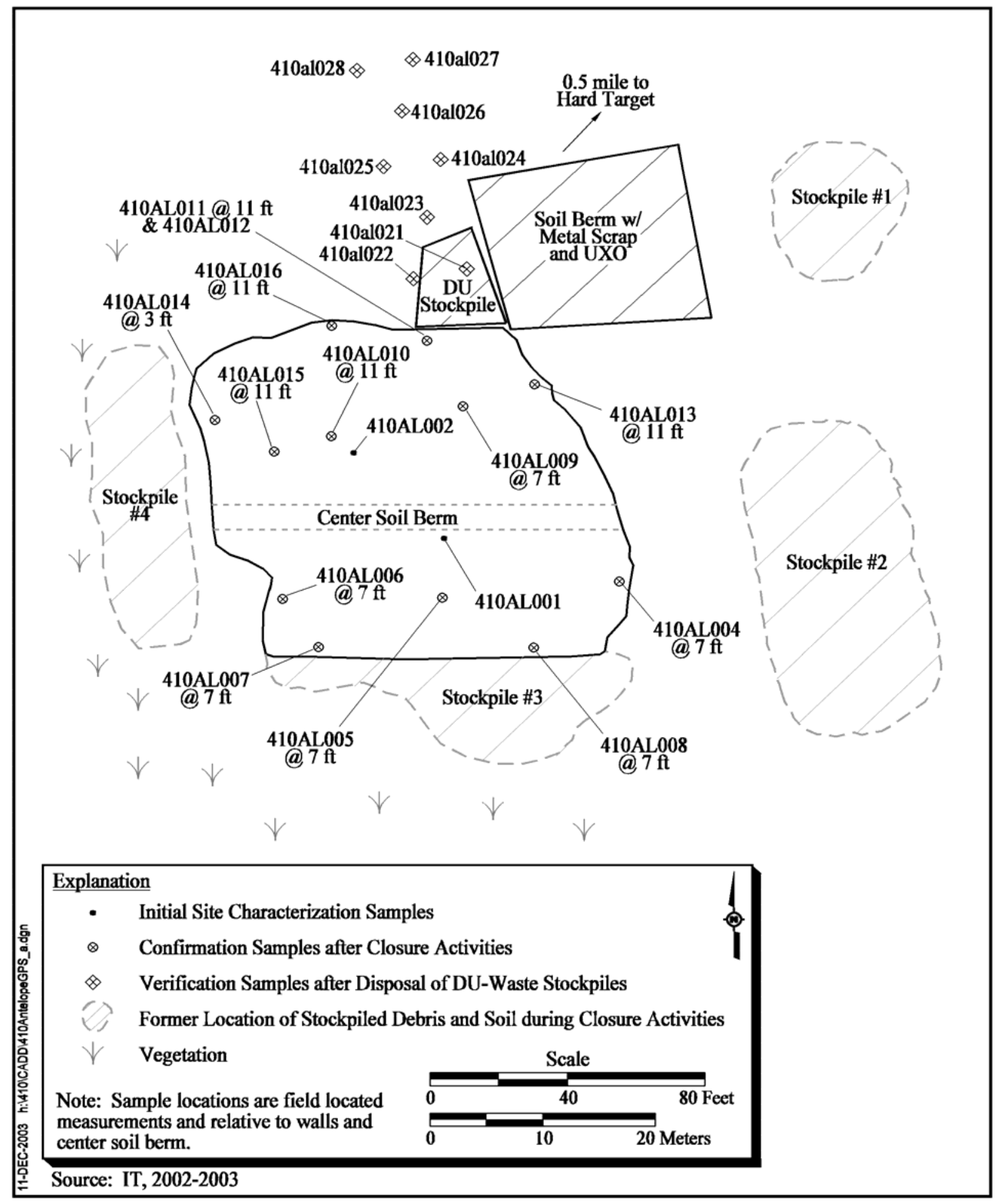

Figure A.6-2

CAU 410, CAS TA-21-002-TAAL, Soil Sampling Locations 


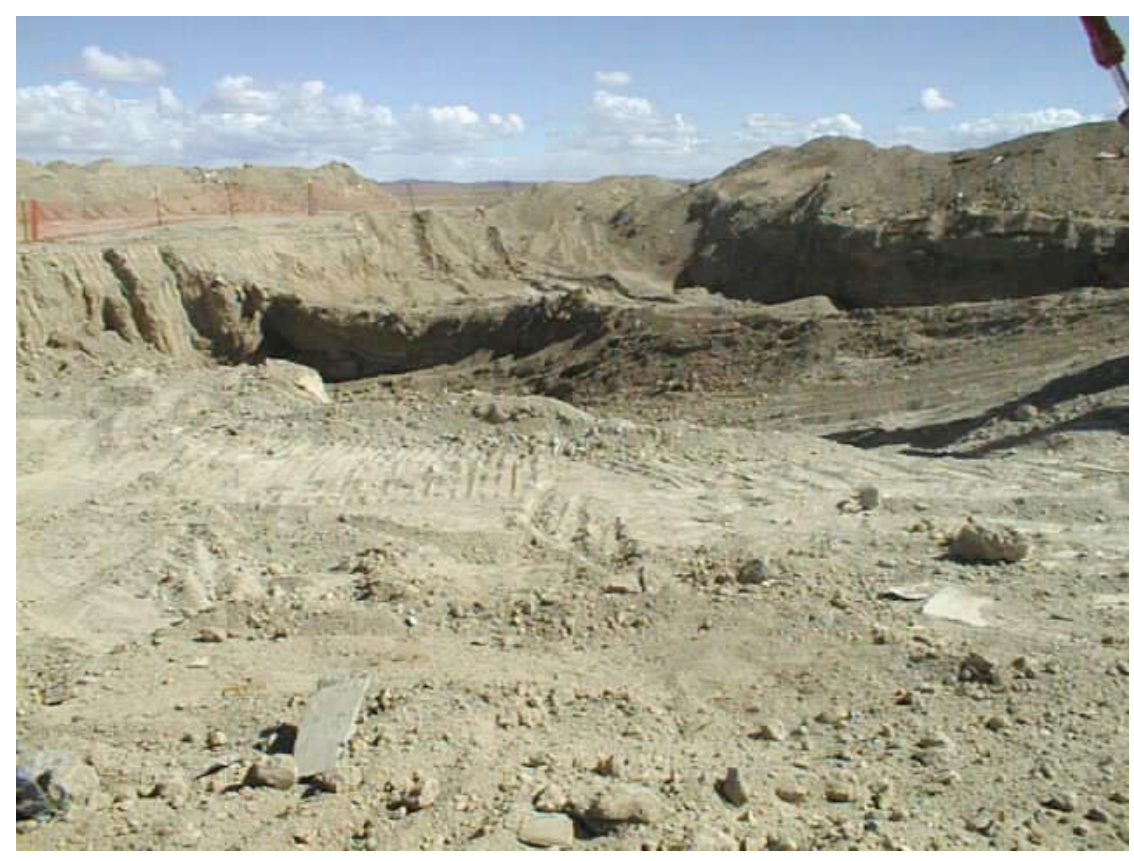

Figure A.6-3

Antelope Lake Excavation

(Excavation after removal of debris, photo taken March 2003)

(sample 410AL018). Additional soil was removed on October 14, 2003, and another nine verification samples (410AL021 to 410AL029) were collected and submitted for isotopic uranium laboratory analysis. Statistical analysis of these most recent analytical results, using the normalized difference test, indicate uranium concentrations in the remaining soil are below PALs.

\section{A.6.3.3 Waste Characterization}

Waste management samples were collected from all stockpiled soil on site and submitted for laboratory analyses of COPCs. Debris, ordnance, and DU-contaminated soil were characterized by radiological surveys and sampling. The DU-contaminated materials were separated and segregated prior to loading into waste disposal containers. All DU waste that was loaded into approved containers during September 2003 was transported for disposal at the Area 3 and Area 5 RWMS at the NTS. The additional soil removed on October 14, 2003, was disposed at the U10C disposal site at the NTS. Nonhazardous waste that was excavated, segregated, and stockpiled was loaded into 
haul trucks and disposed at the TTR construction landfill. The excavation was backfilled with native soil from the TTR borrow pit.

In addition to soil and debris IDW generated during excavation activities at this site, over 1,000 pieces of UXO were identified and segregated from the rest of the debris and contained within established HWAAs pending disposal. Numerous types of ordnance were identified including Beehives, SUSS rounds, 155- and 105-millimeter (mm) rounds, TDD fuses, BLU 63s, Mark 84 (2,000-pound [lb]) and Mark 82 (500-lb) bombs, dispensers, strong backs (actual type unknown), drill rounds, and a 2,000-lb sea mine (later categorized as a Mark 84). Of the approximately 1,000 pieces of UXO, a total of 195 potentially live UXO (as determined by USAF EOD personnel) were demilitarized on site (Figure A.6-4). Forty-six pieces of UXO had fixed DU; therefore, were demilitarized by USAF EOD and Shaw UXO personnel to qualify for final disposition into the NTS LLW disposal site. Any ordnance determined to be inert by USAF EOD personnel (e.g., beehives) were moved to the USAF recycle pile. These activities were conducted in accordance with ROTC No. 4 to the CAIP, which outlined the removal of UXO and ordnance debris from CAS TA-21-002-TAAL, Disposal Trench. The UXO and debris disposal activities are described in greater detail in Appendix D.

\section{A.6.3.4 Sample Analysis}

Investigation and verification soil samples from both the initial and supplemental investigations were submitted for analysis including total VOCs, total SVOCs, total RCRA metals, HEs, total beryllium, gamma spectrometry, TPH-DRO and -GRO, isotopic uranium, and isotopic plutonium. The only exception is for verification samples collected after the removal of the DU-waste stockpile (410AL017 through 410AL029) which were analyzed for isotopic uranium only.

\section{A.6.4 Analytes Detected Above MRL}

The analytical results detected at concentrations exceeding the correlated MRLs at this CAS are summarized in the following sections. 


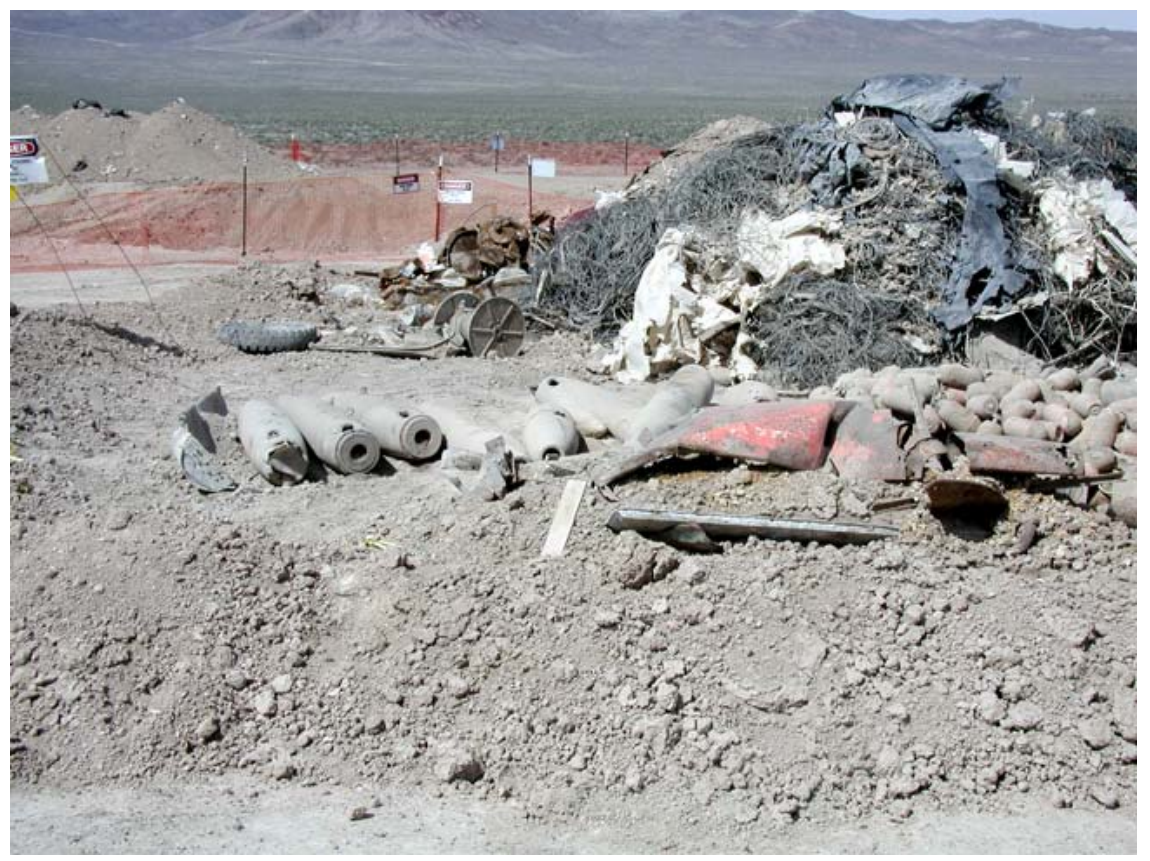

Figure A.6-4

Antelope Lake UXO

(Demilitarized UXO at Antelope Lake, photo taken May 2003)

\section{A.6.4.1 Total VOCs}

The total VOC results for soil samples collected from CAS TA-21-002-TAAL, which were detected above MRLs, are presented on Table A.6-3. All total VOC results are below PALs (NNSA/NV, 2002a).

\section{A.6.4.2 Total Metals}

The total metals results for soil samples collected from CAS TA-21-002-TAAL, which were detected above MRLs, are presented on Table A.6-4. Except for arsenic, all of the total metals results are below PALs (NNSA/NV, 2002a). The arsenic concentrations that exceed the PAL are within the TTR background range and considered representative of ambient conditions. 


\section{Table A.6-3 \\ Soil Sample Results for Total VOCs \\ Detected Above Minimum Reporting Limits at CAS TA-21-002-TAAL}

\begin{tabular}{|c|c|c|c|}
\hline \multirow{2}{*}{$\begin{array}{c}\text { Sample } \\
\text { Number }\end{array}$} & $\begin{array}{c}\text { Sample } \\
\text { Location }\end{array}$ & $\begin{array}{c}\text { Depth } \\
\text { (ft bgs) }\end{array}$ & $\begin{array}{c}\text { Contaminants of } \\
\text { Potential Concern } \\
(\mu \mathrm{g} / \mathrm{kg})\end{array}$ \\
\cline { 3 - 4 } & & Acetone \\
\hline \multicolumn{3}{|c|}{ Preliminary Action Levels ${ }^{\mathrm{a}}$} & $\mathbf{6 , 2 0 0 , 0 0 0}$ \\
\hline \hline 410AL012 & North Sidewall & $10-11$ & 30 \\
\hline
\end{tabular}

\footnotetext{
${ }^{\mathrm{a} B a s e d}$ on U.S. Environmental Protection Agency, Region 9 Preliminary Remediation Goals (PRGs) (EPA, 2000b)

$\mathrm{ft}$ bgs $=$ Feet below ground surface $\mu \mathrm{g} / \mathrm{kg}=$ Micrograms per gram

-- = Not detected above minimum reporting limits
}

\section{A.6.4.3 Isotopic Uranium Results}

The isotopic uranium results for soil samples collected from CAS TA-21-002-TAAL, which were detected above MRLs, are presented on Table A.6-5. Several confirmation samples had U-234 and U-235 concentrations exceeding the respective PALs. Uranium-234 and U-235 analytical results were evaluated using the normalized difference test as discussed in Section A.2.7, and the concentrations in samples 410AL004 through 410AL012, and samples 410AL014 through 410AL029 were considered indistinguishable from the PALs. The only exception was confirmation sample 410AL018, which has U-235 and U-238 concentrations considered statistically above the PAL. This sample represents the ground surface beneath the former DU-waste stockpile. See Section A.6.3.2 for details regarding additional soil removal and sampling.

\section{A.6.4.4 Gamma-Emitting Radionuclides Results}

The gamma-emitting radionuclide results for soil samples collected from CAS TA-21-002-TAAL, which were detected above MRLs, are presented on Table A.6-6. Except for bismuth-212, potassium-40, and thorium-234, the gamma-emitting radionuclides were below PALs (NNSA/NV, 2002a). Several confirmation samples had bismuth-212, potassium-40, and thorium-234 concentrations exceeding the respective PALs. These analytical results were evaluated using the normalized difference test as discussed in Section A.2.7, and the concentrations in these samples are considered indistinguishable from the PALs. 
Table A.6-4

Soil Sample Results for Total Metals Detected

Above Minimum Reporting Limits at CAS TA-21-002-TAAL

\begin{tabular}{|c|c|c|c|c|c|c|c|c|}
\hline \multirow{2}{*}{$\begin{array}{l}\text { Sample } \\
\text { Number }\end{array}$} & \multirow{2}{*}{$\begin{array}{l}\text { Sample } \\
\text { Location }\end{array}$} & \multirow{2}{*}{$\begin{array}{l}\text { Depth } \\
\text { (ft bgs) }\end{array}$} & \multicolumn{6}{|c|}{ Contaminants of Potential Concern (mg/kg) } \\
\hline & & & Arsenic & Barium & Beryllium & Chromium & Lead & Selenium \\
\hline \multicolumn{3}{|c|}{ Preliminary Action Levels ${ }^{a}$} & $23^{b}$ & 100,000 & 2,200 & 450 & 750 & 10,000 \\
\hline 410AL001 & $\begin{array}{c}\text { East End } \\
\text { of Trench \#2 }\end{array}$ & $5.5-6$ & 11.5 & 147 & -- & 12.4 & 14.8 & -- \\
\hline 410AL002 & \multirow{2}{*}{$\begin{array}{l}\text { West End } \\
\text { of Trench \#3 }\end{array}$} & $7.5-8$ & 12.4 & 183 & -- & 14.1 & 15.8 & -- \\
\hline 410AL003 & & $7.5-8$ & 12.1 & 177 & - & 14.3 & 15.9 & - \\
\hline 410AL004 & East Sidewall & $6-7$ & 34 & 180 & 2 & 13 & 19 & -- \\
\hline 410AL005 & Floor - Southend & $6-7$ & 26 & 400 & 1.8 & 13 & 18 & $1.1(\mathrm{~B})$ \\
\hline 410AL006 & West Sidewall & $6-7$ & 19 & 200 & 1.6 & 12 & 18 & -- \\
\hline 410AL007 & \multirow{2}{*}{ South Sidewall } & $6-7$ & 28 & 370 & 2 & 13 & 18 & -- \\
\hline 410AL008 & & $6-7$ & 29 & 690 & 2 & 14 & 19 & -- \\
\hline 410AL009 & \multirow{2}{*}{ Floor Northend } & $10-11$ & 17 & 460 & 1.9 & $13(\mathrm{~J})$ & 17 & -- \\
\hline 410AL010 & & $10-11$ & 23 & 260 & 1.8 & $13(\mathrm{~J})$ & 18 & -- \\
\hline 410AL011 & \multirow{2}{*}{ North Sidewall } & $10-11$ & 15 & 220 & 1.9 & $13(\mathrm{~J})$ & 18 & 1.2 \\
\hline 410AL012 & & $10-11$ & 15 & 190 & 1.8 & $12(\mathrm{~J})$ & 18 & -- \\
\hline 410AL013 & East Sidewall & $10-11$ & 15 & 250 & 1.9 & $13(\mathrm{~J})$ & 17 & -- \\
\hline 410AL014 & West Sidewall & 3 & 13 & 180 & 1.9 & $12(\mathrm{~J})$ & 15 & -- \\
\hline 410AL015 & Floor Northend & $10-11$ & 22 & 470 & 1.9 & $12(\mathrm{~J})$ & 17 & -- \\
\hline 410AL016 & North Sidewall & $10-11$ & 33 & 360 & 2 & $13(\mathrm{~J})$ & 18 & -- \\
\hline
\end{tabular}

${ }^{\mathrm{a}}$ Based on U.S. Environmental Protection Agency, Region 9 Preliminary Remediation Goals (PRGs) (EPA, 2000b)

based on background concentrations for metals. Background is considered the mean plus two standard deviation for sediment samples collected by the Nevada Bureau of Mines and Geology throughout the Nevada Test and Training Range (NBMG, 1998; Moore, 1999).

$\mathrm{ft}$ bgs $=$ Feet below ground surface

$\mathrm{mg} / \mathrm{kg}=$ Milligrams per kilogram

$--=$ Not detected above minimum reporting limits

$B=$ Value less than the instrument detection limit, but greater than or equal to the contract-required detection limit.

$\mathrm{J}=$ Estimated value. Qualifier added to laboratory data; record accepted. Serial dilution \%D outside control limits. Matrix effects may exist.

\section{A.6.5 Contaminants of Concern}

Depleted uranium is identified as a COC based on waste characterization soil samples that represent the DU waste disposed as LLW. Based on the analytical results from the verification samples, there are no COCs identified in remaining soil. 
Table A.6-5

Soil Sample Results for Isotopes Detected Above Minimum Reporting Limits at CAS TA-21-002-TAAL (Page 1 of 2)

\begin{tabular}{|c|c|c|c|c|c|}
\hline \multirow{2}{*}{$\begin{array}{l}\text { Sample } \\
\text { Number }\end{array}$} & \multirow{2}{*}{$\begin{array}{l}\text { Sample } \\
\text { Location }\end{array}$} & \multirow{2}{*}{$\begin{array}{l}\text { Depth } \\
\text { (ft bgs) }\end{array}$} & \multicolumn{3}{|c|}{ Contaminants of Potential Concern (pCi/g) } \\
\hline & & & Uranium-234 & Uranium-235 & Uranium-238 ${ }^{\text {b }}$ \\
\hline \multicolumn{3}{|c|}{ Preliminary Action Levels } & 3.47 & 0.07 & 3.47 \\
\hline 410AL001 & $\begin{array}{c}\text { East End } \\
\text { of Trench \#2 }\end{array}$ & $5.5-6$ & $2.21 \pm 0.41$ & $0.0783 \pm 0.026$ & $1.77 \pm 0.33$ \\
\hline 410AL002 & \multirow{2}{*}{$\begin{array}{l}\text { West End } \\
\text { of Trench \#3 }\end{array}$} & $7.5-8$ & $2.05 \pm 0.39$ & $0.0785 \pm 0.027$ & $1.79 \pm 0.34$ \\
\hline 410AL003 & & $7.5-8$ & $1.97 \pm 0.37$ & $0.0545 \pm 0.021$ & $1.66 \pm 0.31$ \\
\hline 410AL004 & East Sidewall & $6-7$ & $4.2 \pm 0.59$ & $0.2 \pm 0.061$ & $3.1 \pm 0.45$ \\
\hline 410AL005 & $\begin{array}{c}\text { Floor - } \\
\text { Southend }\end{array}$ & $6-7$ & $3.7 \pm 0.53$ & $0.156 \pm 0.054$ & $2.79 \pm 0.41$ \\
\hline 410AL006 & West Sidewall & $6-7$ & $2.94 \pm 0.43$ & $0.128 \pm 0.049$ & $2.3 \pm 0.35$ \\
\hline 410AL007 & \multirow{2}{*}{ South Sidewall } & $6-7$ & $3.63 \pm 0.56$ & $0.124 \pm 0.048$ & $2.97 \pm 0.47$ \\
\hline 410AL008 & & $6-7$ & $4.05 \pm 0.62$ & $0.143 \pm 0.051$ & $3.26 \pm 0.50$ \\
\hline 410AL009 & \multirow{2}{*}{ Floor Northend } & $10-11$ & $2.34 \pm 0.37$ & $0.13 \pm 0.048$ & $2.07 \pm 0.33$ \\
\hline 410AL010 & & $10-11$ & $2.79 \pm 0.44$ & $0.148 \pm 0.053$ & $2.31 \pm 0.37$ \\
\hline 410AL011 & \multirow{2}{*}{ North Sidewall } & $10-11$ & $2.62 \pm 0.41$ & $0.117 \pm 0.045$ & $2.11 \pm 0.34$ \\
\hline 410AL012 & & $10-11$ & $3.04 \pm 0.47$ & $0.131 \pm 0.048$ & $2.32 \pm 0.37$ \\
\hline 410AL013 & East Sidewall & $10-11$ & $2.98 \pm 0.47$ & $0.075 \pm 0.037$ & $2.17 \pm 0.36$ \\
\hline 410AL014 & West Sidewall & 3 & $1.62 \pm 0.27$ & $0.08 \pm 0.038$ & $1.33 \pm 0.23$ \\
\hline 410AL015 & Floor Northend & $10-11$ & $2.75 \pm 0.43$ & $0.115 \pm 0.045$ & $2.24 \pm 0.36$ \\
\hline 410AL016 & North Sidewall & $10-11$ & $4.15 \pm 0.64$ & $0.177 \pm 0.060$ & $3.06 \pm 0.48$ \\
\hline 410AL017 & $\begin{array}{l}\text { Stockpile } \\
\text { location }\end{array}$ & $0-0.5$ & $1.6 \pm 0.27$ & $0.102 \pm 0.046$ & $3.37 \pm 0.50$ \\
\hline 410AL018 & $\begin{array}{l}\text { Stockpile } \\
\text { Location }\end{array}$ & $0-0.5$ & $3.13 \pm 0.48$ & $0.297 \pm 0.087$ & $14.6 \pm 2.0$ \\
\hline 410AL019 & $\begin{array}{l}\text { Stockpile } \\
\text { Location }\end{array}$ & $0-0.5$ & $1.77 \pm 0.29$ & $0.1 \pm 0.046$ & $4.48 \pm 0.65$ \\
\hline 410AL020 & $\begin{array}{l}\text { Stockpile } \\
\text { Location }\end{array}$ & $0-0.5$ & $1.84 \pm 0.30$ & $0.108 \pm 0.047$ & $4 \pm 0.58$ \\
\hline 410AL021 & $\begin{array}{l}\text { Stockpile } \\
\text { Location }\end{array}$ & $0-0.5$ & $1.07 \pm 0.21$ & -- & $1.14 \pm 0.22$ \\
\hline 410AL022 & $\begin{array}{l}\text { Stockpile } \\
\text { Location }\end{array}$ & $0-0.5$ & $1.18 \pm 0.22$ & $0.069 \pm 0.035$ & $1.36 \pm 0.25$ \\
\hline 410AL023 & $\begin{array}{l}\text { Stockpile } \\
\text { Location }\end{array}$ & $0-0.5$ & $1.1 \pm 0.22$ & -- & $1.11 \pm 0.22$ \\
\hline 410AL024 & $\begin{array}{l}\text { Stockpile } \\
\text { Location }\end{array}$ & $0-0.5$ & $1.11 \pm 0.21$ & -- & $0.97 \pm 0.19$ \\
\hline 410AL025 & $\begin{array}{l}\text { Stockpile } \\
\text { Location }\end{array}$ & $0-0.5$ & $1.06 \pm 0.21$ & $0.086 \pm 0.041$ & $1.1 \pm 0.21$ \\
\hline
\end{tabular}




\section{Table A.6-5 \\ Soil Sample Results for Isotopes Detected Above Minimum Reporting Limits at CAS TA-21-002-TAAL} (Page 2 of 2 )

\begin{tabular}{||c|c|c|c|c|c||}
\hline \multirow{2}{*}{$\begin{array}{c}\text { Sample } \\
\text { Number }\end{array}$} & \multirow{2}{*}{$\begin{array}{c}\text { Sample } \\
\text { Location }\end{array}$} & $\begin{array}{c}\text { Depth } \\
\text { (ft bgs) }\end{array}$ & \multicolumn{2}{|c|}{ Contaminants of Potential Concern (pCi/g) } \\
\cline { 4 - 6 } & & Uranium-234 & Uranium-235 $^{\mathbf{b}}$ & Uranium-238 $^{\mathbf{b}}$ \\
\hline \multicolumn{2}{|c|}{ Preliminary Action Levels } & $\mathbf{3 . 4 7}$ & $\mathbf{0 . 0 7}$ & $\mathbf{3 . 4 7}$ \\
\hline \hline 410AL026 & $\begin{array}{l}\text { Stockpile } \\
\text { Location }\end{array}$ & $0-0.5$ & $1.13 \pm 0.22$ & $0.099 \pm 0.043$ & $1.04 \pm 0.2$ \\
\hline 410AL027 & $\begin{array}{l}\text { Stockpile } \\
\text { Location }\end{array}$ & $0-0.5$ & $1.13 \pm 0.22$ & $0.055 \pm 0.031$ & $1.17 \pm 0.22$ \\
\hline 410AL028 & $\begin{array}{l}\text { Stockpile } \\
\text { Location }\end{array}$ & $0-0.5$ & $1.22 \pm 0.24$ & -- & $1.02 \pm 0.2$ \\
\hline 410AL029 & $\begin{array}{l}\text { Stockpile } \\
\text { Location }\end{array}$ & $0-0.5$ & $1.39 \pm 0.26$ & $0.103 \pm 0.046$ & $1.18 \pm 0.23$ \\
\hline
\end{tabular}

\footnotetext{
${ }^{a} B a s e d$ on background concentration listed or derived in Off-Site Radiation Exposure Review Project, Phase II Soil Program (McArthur and Miller, 1989)

${ }^{b}$ Based on background concentration listed in Environmental Monitoring Report for the Proposed Ward Valley, California, Low-Level Radioactive Waste (LLRW) Facility (US Ecology and Atlan-Tech, 1991)

$\mathrm{ft}$ bgs $=$ Feet below ground surface $\mathrm{pCi} / \mathrm{g}=$ Picocuries per gram

$--=$ Not detected above minimum reporting limits
}

\section{A.6.6 Nature and Extent of Contamination}

The nature and extent of DU-contaminated soil, miscellaneous debris, and UXO was delineated through excavation, removal, and segregation of all materials from the historical disposal trench. Analytical results from confirmation samples collected from the excavation floors and sidewalls indicate there are no COCs remaining at this site.

\section{A.6.7 Revised Conceptual Site Model}

The only significant variation to the CSM was the identification of depleted uranium contamination within the disposal trench; however, no variations to the CSM were identified for migration or exposure pathways. 
Table A.6-6

Soil Sample Results for Gamma-Emitting Radionuclides Detected Above Minimum Reporting Limits at CAS TA-21-002-TAAL (Page 1 of 2)

\begin{tabular}{|c|c|c|c|c|c|c|c|c|c|c|c|c|}
\hline \multirow[b]{2}{*}{$\begin{array}{l}\text { Sample } \\
\text { Number }\end{array}$} & \multirow[b]{2}{*}{$\begin{array}{l}\text { Sample } \\
\text { Location }\end{array}$} & \multirow[b]{2}{*}{$\begin{array}{c}\text { Depth } \\
\text { (ft bgs) }\end{array}$} & \multicolumn{10}{|c|}{ Contaminants of Potential Concern $(\mathrm{pCi} / \mathrm{g})$} \\
\hline & & & 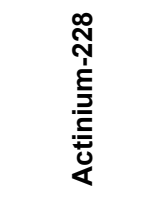 & 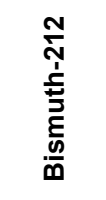 & 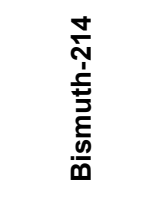 & 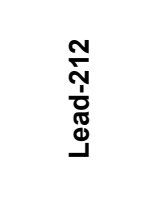 & 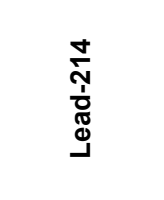 & 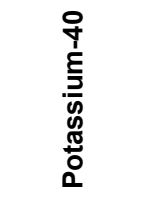 & 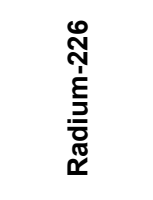 & 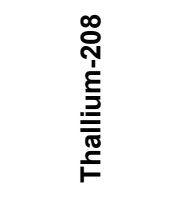 & 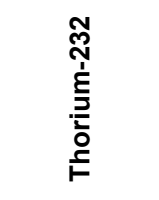 & 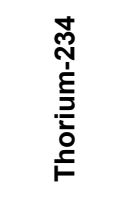 \\
\hline \multicolumn{3}{|c|}{ Preliminary Action Levels } & $3.64^{a}$ & $3.64^{\mathrm{a}}$ & $3.47^{\mathrm{a}}$ & $3.64^{a}$ & $3.47^{\mathrm{a}}$ & $30.7^{\mathrm{b}}$ & $3.47^{\mathrm{a}}$ & $3.38^{\mathrm{a}}$ & $3.64^{\mathrm{a}}$ & $3.47^{\mathrm{a}}$ \\
\hline 410AL001 & $\begin{array}{l}\text { East end of } \\
\text { Trench \#2 }\end{array}$ & $5.5-6$ & $2.51 \pm 0.57$ & -- & -- & $1.62 \pm 0.41$ & $2.01 \pm 0.41$ & $32.6 \pm 4.7$ & -- & $0.776 \pm 0.18$ & $2.6 \pm 0.84$ & -- \\
\hline 410AL002 & \multirow{2}{*}{$\begin{array}{c}\text { West End of } \\
\text { Trench \#3 }\end{array}$} & $7.5-8$ & $1.76 \pm 0.55$ & -- & -- & $2.34 \pm 0.43$ & $2.14 \pm 0.46$ & $30.5 \pm 4.5$ & $1.91 \pm 0.39$ & $0.658 \pm 0.17$ & $2.42 \pm 0.84$ & -- \\
\hline 410AL003 & & $7.5-8$ & $1.93 \pm 0.53$ & -- & -- & $2.29 \pm 0.44$ & $1.85 \pm 0.4$ & $29.5 \pm 4.5$ & -- & $0.78 \pm 0.19$ & $2.65 \pm 0.8$ & -- \\
\hline 410AL004 & $\begin{array}{c}\text { East } \\
\text { Sidewall }\end{array}$ & $6-7$ & $2.04 \pm 0.52$ & -- & $2.26 \pm 0.52$ & $2.16 \pm 0.44$ & $2.44 \pm 0.48$ & $29.8 \pm 6.0$ & -- & $0.76 \pm 0.2$ & -- & -- \\
\hline 410AL005 & $\begin{array}{l}\text { Floor - } \\
\text { Southend }\end{array}$ & $6-7$ & $1.67 \pm 0.48$ & -- & $1.99 \pm 0.47$ & $2.27 \pm 0.46$ & $2.04 \pm 0.43$ & $31.1 \pm 6.4$ & -- & $0.89 \pm 0.22$ & -- & -- \\
\hline 410AL006 & $\begin{array}{c}\text { West } \\
\text { Sidewall }\end{array}$ & $6-7$ & $1.89 \pm 0.46$ & -- & $1.79 \pm 0.40$ & $2.16 \pm 0.42$ & $1.92 \pm 0.39$ & $30.2 \pm 5.9$ & -- & $0.76 \pm 0.19$ & -- & -- \\
\hline 410AL007 & \multirow{2}{*}{$\begin{array}{l}\text { South Side- } \\
\text { wall }\end{array}$} & $6-7$ & $2.14 \pm 0.56$ & -- & $2.05 \pm 0.49$ & $2.39 \pm 0.48$ & $2.14 \pm 0.44$ & $26.4 \pm 5.5$ & -- & $0.77 \pm 0.21$ & -- & -- \\
\hline 410AL008 & & $6-7$ & $2.01 \pm 0.50$ & $4 \pm 1.6$ & $1.78 \pm 0.42$ & $2.11 \pm 0.43$ & $2.06 \pm 0.42$ & $28.8 \pm 5.8$ & -- & $0.55 \pm 0.18$ & -- & $3.5 \pm 1.2$ \\
\hline 410AL009 & \multirow{2}{*}{$\begin{array}{c}\text { Floor } \\
\text { Northend }\end{array}$} & $10-11$ & $2.16 \pm 0.55$ & -- & $1.66 \pm 0.40$ & $2.17 \pm 0.45$ & $1.71 \pm 0.38$ & $32.6 \pm 6.4$ & -- & $0.76 \pm 0.20$ & -- & -- \\
\hline 410AL010 & & $10-11$ & $1.92 \pm 0.54$ & -- & $2.1 \pm 0.50$ & $2.73 \pm 0.55$ & $2.08 \pm 0.45$ & $32.4 \pm 6.6$ & -- & $0.68 \pm 0.21$ & -- & -- \\
\hline 410AL011 & \multirow{2}{*}{$\begin{array}{c}\text { North } \\
\text { Sidewall }\end{array}$} & $10-11$ & $2.1 \pm 0.52$ & -- & $2 \pm 0.44$ & $2.29 \pm 0.46$ & $2.07 \pm 0.42$ & $31.9 \pm 6.2$ & -- & $0.61 \pm 0.18$ & -- & -- \\
\hline 410AL012 & & $10-11$ & $1.74 \pm 0.49$ & -- & $1.85 \pm 0.46$ & $2.23 \pm 0.46$ & $1.99 \pm 0.42$ & $28 \pm 5.8$ & -- & $0.63 \pm 0.18$ & -- & -- \\
\hline 410AL013 & $\begin{array}{c}\text { East } \\
\text { Sidewall }\end{array}$ & $10-11$ & $2.16 \pm 0.46$ & -- & $1.77 \pm 0.36$ & $2.29 \pm 0.42$ & $2.09 \pm 0.39$ & $34.5 \pm 6.1$ & -- & $0.75 \pm 0.16$ & -- & -- \\
\hline
\end{tabular}


Table A.6-6

Soil Sample Results for Gamma-Emitting Radionuclides Detected Above Minimum Reporting Limits at CAS TA-21-002-TAAL

$$
\text { (Page } 2 \text { of 2) }
$$

\begin{tabular}{|c|c|c|c|c|c|c|c|c|c|c|c|c|}
\hline \multirow[b]{2}{*}{$\begin{array}{c}\text { Sample } \\
\text { Number }\end{array}$} & \multirow[b]{2}{*}{$\begin{array}{c}\text { Sample } \\
\text { Location }\end{array}$} & \multirow[b]{2}{*}{$\begin{array}{c}\text { Depth } \\
\text { (ft bgs) }\end{array}$} & \multicolumn{10}{|c|}{ Contaminants of Potential Concern (pCi/g) } \\
\hline & & & 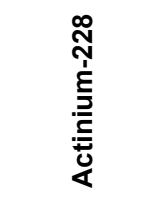 & 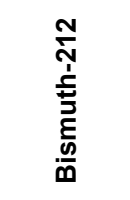 & 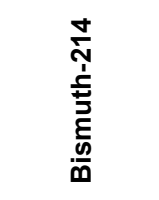 & 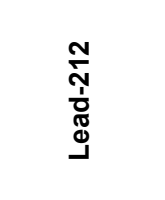 & 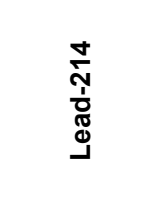 & 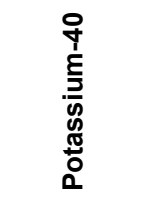 & 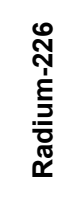 & 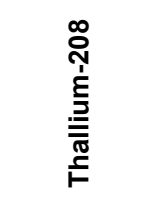 & 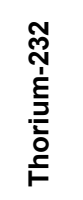 & 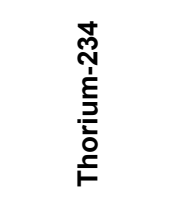 \\
\hline \multicolumn{3}{|c|}{ Preliminary Action Levels } & $3.64^{a}$ & $3.64^{\mathrm{a}}$ & $3.47^{\mathrm{a}}$ & $3.64^{\mathrm{a}}$ & $3.47^{\mathrm{a}}$ & $30.7^{b}$ & $3.47^{\mathrm{a}}$ & $3.38^{\mathrm{a}}$ & $3.64^{\mathrm{a}}$ & $3.47^{\mathrm{a}}$ \\
\hline 410AL014 & $\begin{array}{c}\text { West } \\
\text { Sidewall }\end{array}$ & 3 & $1.59 \pm 0.43$ & -- & $1.25 \pm 0.32$ & $2.34 \pm 0.46$ & $1.44 \pm 0.32$ & $28.6 \pm 5.7$ & -- & $0.6 \pm 0.17$ & -- & -- \\
\hline 410AL015 & $\begin{array}{c}\text { Floor } \\
\text { Northend }\end{array}$ & $10-11$ & $1.75 \pm 0.55$ & -- & $1.96 \pm 0.49$ & $2.37 \pm 0.49$ & $2.16 \pm 0.46$ & $25.4 \pm 5.4$ & -- & $0.6 \pm 0.19$ & -- & -- \\
\hline 410AL016 & $\begin{array}{c}\text { North } \\
\text { Sidewall }\end{array}$ & $10-11$ & $1.78 \pm 0.51$ & $3.8 \pm 1.5$ & $2.63 \pm 0.57$ & $2.42 \pm 0.48$ & $2.89 \pm 0.56$ & $25.8 \pm 5.4$ & -- & $0.78 \pm 0.21$ & -- & $5.7 \pm 2.1$ (TI) \\
\hline
\end{tabular}

a Based on background concentration reported in Environmental Monitoring Report for the Proposed Ward Valley, California, Low-Level Radioactive Waste (LLRW) Facility (US Ecology and Atlan-Tech, 1991)

${ }^{\mathrm{b} B a s e d}$ on background concentration listed or derived in Off-Site Radiation Exposure Review Project, Phase // Soil Program (McArthur and Miller, 1989)

\section{$\mathrm{ft}$ bgs $=$ Feet below ground surface}

$\mathrm{pCi} / \mathrm{g}=$ Picocuries per gram

$--=$ Not detected above minimum reporting limits

$\mathrm{TI}=$ Tentatively identified 


\section{A.7.0 CAS 03-19-001, Waste Disposal Site}

This CAS is located within the Area 3 compound in the northwestern corner. This site was identified based on the CAU 405 investigation of a septic system where debris and elevated TPH FSRs were identified at a depth of 4.5- to 5-ft bgs and approximately 15-ft south of the CAU 405 investigation. Prior to the investigation, there was no surface debris present and subsurface geophysical survey results were inclusive. The site is bounded physically by the Area 3 perimeter fence to the west, Building 0385 on the north, and the current CAU 424 use-restriction for a landfill on the south. The CAU 424 use restriction was not entered during the investigation of this CAS.

\section{A.7.1 Corrective Action Investigation}

A total of 40 (5 site characterization, 34 confirmation, and 1 background) environmental soil samples were collected and submitted for laboratory analyses. Four QC duplicate samples, one QC field blank, one QC equipment rinsate blank, two source blanks, and 15 QC trip blanks were collected and submitted for laboratory analysis. A list of the samples collected and the parameters analyzed for are presented in Table A.7-1.

Table A.7-1 also provides sample information on the 11 waste management soil samples collected and submitted for analysis. Although presented in this table for completeness, discussion regarding sample collection and the waste management analytical results are provided in Appendix D.

\section{A.7.2 CAIP Implementation}

The following CAI activities were performed to meet the CAIP requirements:

- Excavated within the CAS footprint to identify nature and extent of TPH-contaminated soils and buried burn pit materials

- Field screened soils for alpha and beta/gamma radiation and TPH

- Collected biased subsurface samples within the burn pit materials

- Collected confirmation samples from the excavation sidewalls and floor

- Segregated and separated soil and debris for proper waste disposal

- Conducted waste characterization sampling

- Disposed of all IDW from the site and backfilled the excavation with clean fill 
Table A.7-1

Samples Collected for CAS 03-19-001, Waste Disposal Site

(Page 1 of 3 )

\begin{tabular}{|c|c|c|c|c|c|c|}
\hline $\begin{array}{l}\text { Sample } \\
\text { Number }\end{array}$ & $\begin{array}{c}\text { Sample } \\
\text { Collection } \\
\text { Date }\end{array}$ & $\begin{array}{c}\text { Sample } \\
\text { Location }\end{array}$ & $\begin{array}{l}\text { Depth } \\
\text { (ft bgs) }\end{array}$ & $\begin{array}{l}\text { Sample } \\
\text { Matrix }\end{array}$ & Purpose & Analyses \\
\hline 41003001 & \multirow{6}{*}{$10 / 29 / 2002$} & Excavation 1 & $4.5-5$ & Soil & $\mathrm{SC}, \mathrm{Lab} \mathrm{QC}$ & TPH-DRO \\
\hline 41003002 & & Excavation 2 & $4.5-5$ & Soil & $\mathrm{SC}$ & TPH-DRO \\
\hline 41003003 & & \multirow[b]{2}{*}{ Excavation 3} & $4.5-5$ & Soil & $\mathrm{SC}$ & TPH-DRO \\
\hline 41003004 & & & $4.5-5$ & Soil & $\begin{array}{l}\text { Field Duplicate of } \\
\quad \# 41003003\end{array}$ & TPH-DRO \\
\hline 41003005 & & Excavation 5 & $4.5-5$ & Soil & SC & TPH-DRO \\
\hline 41003006 & & Excavation 4 & $4.5-5$ & Soil & SC & TPH-DRO \\
\hline $41003006 \mathrm{~A}$ & \multirow{3}{*}{$3 / 4 / 2003$} & \multirow{3}{*}{$\begin{array}{c}\text { North Sidewall - } \\
\text { Burn Pit }\end{array}$} & $4.5-5$ & Soil & Confirmation, WM & Set 4 \\
\hline 41003007 & & & $4.5-5$ & Soil & Confirmation, WM & Set 4 \\
\hline 41003008 & & & $4.5-5$ & Soil & $\begin{array}{l}\text { Field Duplicate of } \\
\quad \# 41003007\end{array}$ & Set 4 \\
\hline 41003009 & \multirow{2}{*}{$3 / 24 / 2003$} & \multirow{2}{*}{ Pothole \#2 } & 7 & Soil & Confirmation & Set 5 \\
\hline 41003010 & & & $0-1$ & Soil & Confirmation & Set 5 \\
\hline 41003011 & $3 / 25 / 2003$ & Pothole \#3 & 7 & Soil & Confirmation & Set 5 \\
\hline 41003012 & \multirow{3}{*}{$3 / 27 / 2003$} & $\begin{array}{c}\text { South Sidewall - } \\
\text { Burn Pit }\end{array}$ & $4-5$ & Soil & Confirmation & Set 6 \\
\hline 41003013 & & $\begin{array}{c}\text { West Sidewall - } \\
\text { Burn Pit }\end{array}$ & $6-7$ & Soil & Confirmation & Set 6 \\
\hline 41003014 & & $\begin{array}{c}\text { North Sidewall - } \\
\text { Burn Pit }\end{array}$ & $8-9$ & Soil & Confirmation & Set 6 \\
\hline 41003015 & \multirow{10}{*}{$4 / 9 / 2003$} & \multirow{2}{*}{ Boring B01 } & $12-13.5$ & Soil & Confirmation & Set 7 \\
\hline 41003016 & & & $17-18.5$ & Soil & Confirmation & Set 7 \\
\hline 41003017 & & \multirow{2}{*}{ Boring B02 } & $8-9.5$ & Soil & Confirmation & Set 7 \\
\hline 41003018 & & & $12-13.5$ & Soil & Confirmation & Set 7 \\
\hline 41003019 & & \multirow{2}{*}{ Boring B03 } & $8-9.5$ & Soil & Confirmation & Set 7 \\
\hline 41003020 & & & $12-13.5$ & Soil & Confirmation & Set 7 \\
\hline 41003021 & & \multirow{3}{*}{ Boring B04 } & $8-9.5$ & Soil & Confirmation & Set 7 \\
\hline 41003022 & & & $8-9.5$ & Soil & $\begin{array}{c}\text { Field Duplicate of } \\
\quad \# 4100321\end{array}$ & Set 7 \\
\hline 41003023 & & & $12-13.5$ & Soil & Confirmation & Set 7 \\
\hline 41003024 & & Boring B05 & $12-13.5$ & Soil & Confirmation & Set 7 \\
\hline 41003025 & \multirow{2}{*}{ 4/10/2003 } & Boring B06 & $7.5-9$ & Soil & Confirmation & Set 7 \\
\hline 41003026 & & Boring B08 & $9.5-11$ & Soil & Confirmation & Set 7 \\
\hline 41003027 & $4 / 29 / 2003$ & $\begin{array}{c}\text { South Sidewall - } \\
\text { Burn Pit }\end{array}$ & $8-9$ & Soil & Confirmation & Set 7 \\
\hline
\end{tabular}


Table A.7-1

Samples Collected for CAS 03-19-001, Waste Disposal Site

(Page 2 of 3 )

\begin{tabular}{|c|c|c|c|c|c|c|}
\hline $\begin{array}{l}\text { Sample } \\
\text { Number }\end{array}$ & $\begin{array}{c}\text { Sample } \\
\text { Collection } \\
\text { Date }\end{array}$ & $\begin{array}{c}\text { Sample } \\
\text { Location }\end{array}$ & $\begin{array}{l}\text { Depth } \\
\text { (ft bgs) }\end{array}$ & $\begin{array}{l}\text { Sample } \\
\text { Matrix }\end{array}$ & Purpose & Analyses \\
\hline 41003028 & \multirow{2}{*}{ 4/30/2003 } & \multirow{2}{*}{ Floor - Burn Pit } & $10-12$ & Soil & Confirmation & Set 7 \\
\hline 41003029 & & & $10-12$ & Soil & Confirmation & Set 7 \\
\hline 41003030 & \multirow{2}{*}{$5 / 2 / 2003$} & $\begin{array}{c}\text { North Sidewall - } \\
\text { TPH Pit }\end{array}$ & $3-4$ & Soil & Confirmation & TPH-DRO \\
\hline 41003031 & & $\begin{array}{c}\text { South Sidewall - } \\
\text { TPH Pit }\end{array}$ & $12-14$ & Soil & Confirmation & TPH-DRO \\
\hline 41003032 & \multirow{3}{*}{$5 / 5 / 2003$} & $\begin{array}{c}\text { North Sidewall - } \\
\text { TPH Pit }\end{array}$ & $16-17$ & Soil & Confirmation & TPH-DRO \\
\hline 41003033 & & \multirow{2}{*}{$\begin{array}{c}\text { West Sidewall - } \\
\text { TPH Pit }\end{array}$} & $6-8$ & Soil & Confirmation & TPH-DRO \\
\hline 41003034 & & & $15-16$ & Soil & Confirmation & TPH-DRO \\
\hline 41003035 & \multirow{4}{*}{$5 / 6 / 2003$} & \multirow{2}{*}{$\begin{array}{c}\text { South Sidewall - } \\
\text { TPH Pit }\end{array}$} & $6-8$ & Soil & Confirmation & TPH-DRO \\
\hline 41003036 & & & $10-12$ & Soil & Confirmation & TPH-DRO \\
\hline 41003037 & & Floor - TPH Pit & $16-17$ & Soil & Confirmation & TPH-DRO \\
\hline 41003038 & & $\begin{array}{c}\text { South Sidewall - } \\
\text { TPH Pit }\end{array}$ & $3-4$ & Soil & Confirmation & TPH-DRO \\
\hline 41003039 & \multirow{4}{*}{$5 / 2 / 2003$} & $\begin{array}{c}\text { North Sidewall - } \\
\text { TPH Pit }\end{array}$ & $10-12$ & Soil & Confirmation & TPH-DRO \\
\hline 41003040 & & $\begin{array}{c}\text { South Sidewall - } \\
\text { TPH Pit }\end{array}$ & $3-4$ & Soil & Background & TPH-DRO \\
\hline 41003041 & & $\begin{array}{c}\text { North Sidewall - } \\
\text { TPH Pit }\end{array}$ & $2-3$ & Soil & Confirmation & TPH-DRO \\
\hline 41003042 & & Floor - TPH Pit & $14-16$ & Soil & Confirmation & TPH-DRO \\
\hline 41003301 & $12 / 16 / 2002$ & NA & NA & Water & Trip Blank & Total VOCs \\
\hline 41003302 & $10 / 31 / 2002$ & NA & NA & Water & Field Blank & TPH-DRO \\
\hline 41003303 & $3 / 4 / 2003$ & NA & NA & Water & Trip Blank & Total VOCs \\
\hline 41003304 & $3 / 24 / 2003$ & NA & NA & Water & Trip Blank & Total VOCs \\
\hline 41003305 & $3 / 25 / 2003$ & NA & NA & Water & Trip Blank & Total VOCs \\
\hline 41003306 & \multirow{5}{*}{$3 / 27 / 2003$} & NA & NA & Water & Trip Blank & Total VOCs \\
\hline 41003307 & & NA & NA & Water & Trip Blank & Total VOCs \\
\hline 41003308 & & NA & NA & Water & Source Blank & Set 5 \\
\hline 41003309 & & NA & NA & Water & $\begin{array}{c}\text { Equipment } \\
\text { Rinsate Blank }\end{array}$ & Set 5 \\
\hline 41000310 & & NA & NA & Water & WM & Set 5 \\
\hline 41003311 & \multirow{2}{*}{ 4/9/2003 } & NA & NA & Water & Trip Blank & Total VOCs \\
\hline 41003312 & & NA & NA & Water & Trip Blank & Total VOCs \\
\hline
\end{tabular}


Table A.7-1

Samples Collected for CAS 03-19-001, Waste Disposal Site

(Page 3 of 3 )

\begin{tabular}{|c|c|c|c|c|c|c|}
\hline $\begin{array}{l}\text { Sample } \\
\text { Number }\end{array}$ & $\begin{array}{c}\text { Sample } \\
\text { Collection } \\
\text { Date }\end{array}$ & $\begin{array}{l}\text { Sample } \\
\text { Location }\end{array}$ & $\begin{array}{l}\text { Depth } \\
\text { (ft bgs) }\end{array}$ & $\begin{array}{l}\text { Sample } \\
\text { Matrix }\end{array}$ & Purpose & Analyses \\
\hline 41003313 & \multirow{3}{*}{ 4/10/2003 } & $\overline{N A}$ & $\overline{N A}$ & Water & Trip Blank & Total VOCs \\
\hline 41003314 & & NA & NA & Water & Trip Blank & Total VOCs \\
\hline 41003315 & & NA & NA & Water & Source Blank & Set 5 \\
\hline 41003316 & \multirow{2}{*}{$4 / 15 / 2003$} & NA & NA & Water & Trip Blank & Total VOCs \\
\hline 41003317 & & NA & NA & Water & WM & Set 5 \\
\hline 41003318 & $4 / 29 / 2003$ & NA & NA & Water & Trip Blank & Total VOCs \\
\hline 41003319 & $4 / 30 / 2003$ & NA & NA & Water & Trip Blank & Total VOCs \\
\hline 41003320 & $5 / 2 / 2003$ & NA & NA & Water & Trip Blank & Total VOCs \\
\hline 41003501 & \multirow[b]{2}{*}{ 12/16/2002 } & NA & NA & Water & WM & Set 6 \\
\hline 41003502 & & NA & NA & Water & $\begin{array}{l}\text { Field Duplicate of } \\
\quad \# 41003501\end{array}$ & Set 6 \\
\hline 41003503 & $1 / 8 / 2003$ & NA & NA & Water & WM & Isotopic Uranium \\
\hline 41003504 & $5 / 2 / 2003$ & NA & NA & Soil & WM & Set 8 \\
\hline 410WM501 & \multirow{6}{*}{$9 / 25 / 03$} & NA & NA & Water & Trip Blank & VOCs \\
\hline 410WM502 & & NA & NA & Liquid & WM & VOCs \\
\hline 410WM503 & & NA & NA & Liquid & WM & Flashpoint \\
\hline 410WM504 & & NA & NA & Liquid & WM & VOCs \\
\hline 410WM505 & & NA & NA & Liquid & WM & Flashpoint \\
\hline 410WM506 & & NA & NA & Liquid & WM & SVOCs \\
\hline
\end{tabular}

Set 4 = Total VOCs, Total SVOCs, Total RCRA Metals, HEs, TPH (DRO and GRO), Gamma Spectrometry, PCBs, Pesticides, and Herbicides

Set 5 = Total VOCs, Total SVOCs, Total RCRA Metals, Total Beryllium, HEs, TPH (DRO and GRO), Isotopic Uranium, Isotopic Plutonium, Gamma Spectrometry, PCBs, Pesticides, and Herbicides

Set 6 = Total VOCs, Total SVOCs, Total RCRA Metals, Total Beryllium, HEs, TPH (DRO and GRO), Isotopic Uranium, Isotopic Plutonium, and Gamma Spectrometry

Set 7 = Total VOCs, Total SVOCs, Total RCRA Metals, TPH (DRO and GRO), and Gamma Spectrometry

Set $8=$ Total VOCs, Total SVOCs, Total RCRA Metals, TPH (DRO and GRO), and Gamma Spectrometry

TPH-DRO = Total Petroleum Hydrocarbons-Diesel-Range Organics

$\mathrm{WM}=$ Waste management

$\mathrm{SC}=$ Site characterization

NA $=$ Not applicable

$\mathrm{QC}=$ Quality control

$\mathrm{ft}$ bgs $=$ Feet below ground surface 


\section{A.7.2.1 Deviations}

Because of changes in the scope of investigation activities, two ROTCs to the CAIP were implemented for this CAS. During the initial CAI activities in October 2002, undisturbed soil deposits were encountered in a trench excavation located approximately 15-ft south of the original SWS-4 sample location where FSRs exceeded FSLs for TPH-DRO during the CAU 405 investigation. Neither debris or stained soil were observed in the sides and/or bottom of the trench and none of the five samples collected indicated the presence of TPH.

Based on the October 2002 excavation and the historical investigation results, it was assumed that the TPH contamination was restricted to the immediate vicinity of the SWS-4 location at a depth of 4.5 to $5 \mathrm{ft}$ bgs, in an area of approximately 30 cubic feet $\left(\mathrm{ft}^{3}\right)$, with an approximate volume of 12 cubic yards $\left(\mathrm{yd}^{3}\right)$. On this basis, ROTC No. 1 to the CAIP was submitted for supplemental field activities that included defining the site boundaries by excavation and delineating the vertical limits of potential TPH-DRO. It was anticipated that following the completion of limited excavation activities in the vicinity of SWS-4 that the remaining area of the CAS would be free of TPH-DRO greater than the PAL.

During the supplemental excavation activities on March 3 and 4, 2003, under ROTC No. 1, the investigation at 03-19-001 found significantly deeper (over $9 \mathrm{ft}$ bgs) and larger volumes of stained soil and debris beyond the anticipated boundaries. Therefore, ROTC No. 3 to the CAIP was implemented for additional excavation activities to better define horizontal and vertical limits of the TPH-DRO contamination based on the most recent investigation results. An additional deviation from the CAIP was the use of hollow-stem auger drilling to aid in delineating TPH-DRO soil contamination without excavating large volumes of overburden.

\section{A.7.3 Investigation Activities}

The following sections provide CAS-specific details of excavation, drilling, field screening, and sample collection and analysis. The various phases of the supplemental excavation activities for CAS 03-19-001 are summarized in Table A.7-2. 
Table A.7-2

Summary of Excavation Activities at CAS 03-19-001

\begin{tabular}{|c|l||}
\hline Date of Activities & \multicolumn{1}{|c|}{ Activity Summary } \\
\hline \hline October 29, 2002 & $\begin{array}{l}\text { Samples 41003001 through 41003006 were collected from locations of elevated FSRs for TPH during } \\
\text { the CAU 405 investigation. }\end{array}$ \\
\hline March 3 and 4,2003 & $\begin{array}{l}\text { Samples 41003006A through 41003008 were collected from stained soil and burned debris after } \\
\text { being identified along the northern sidewall of the burn pit excavation activities. }\end{array}$ \\
\hline March 24 to 27, 2003 & $\begin{array}{l}\text { Began pothole excavation in attempt to delineate boundaries of debris and staining. Samples } \\
\text { 41003009 through 41003014 were collected from potholes \#2 and \#3 and the south, west, and } \\
\text { northern sides of the original burn pit excavation. }\end{array}$ \\
\hline April 7 to 10,2003 & $\begin{array}{l}\text { Hollow-stem auger drilling used to further delineate TPH contamination on the southern end of the } \\
\text { burn pit and attempt to define lateral limits of debris. Samples 41003015 through 41003026 were } \\
\text { collected from soil borings B01 through B05, B06, and B08. }\end{array}$ \\
\hline April 29 and 30,2003 & $\begin{array}{l}\text { Completed excavation of the burn pit to define north, east, and south boundaries. Confirmation } \\
\text { samples 41003027, 41003028, and 41003029 were collected from the south side wall and floor of the } \\
\text { burn pit. }\end{array}$ \\
\hline May 1 to 6, 2003 & $\begin{array}{l}\text { Started and completed excavation of the TPH area. Samples 41003030 through 41003042 were } \\
\text { collected from the sidewalls and floor of the TPH excavation. }\end{array}$ \\
\hline
\end{tabular}

\section{A.7.3.1 Field Screening}

Soil samples were field screened for TPH-DRO and alpha and beta/gamma radiation. Established FSLs were used to guide sample collection, sample selection for laboratory analysis, and extent of excavation and drilling activities. Field-screening results for soil-screening samples collected from several subsurface locations within the CAS footprint exceeded the established TPH FSL of $75 \mathrm{ppm}$ using Petroflag test kit. There were no FSRs that exceeded radiological FSLs.

Based on the FSRs and associated laboratory analytical results collected early in the investigation, it was determined that results of the Petroflag screening kit generally trended higher than the laboratory analytical results. While the FSL was not changed, several samples were submitted for laboratory analysis with FSRs above the FSL and excavation would be suspended in those locations pending laboratory results confirming TPH concentrations below action levels.

\section{A.7.3.2 Excavation}

During the October 2002 investigation, undisturbed soil deposits were encountered in an excavation located approximately $15 \mathrm{ft}$ south of the original CAU 405 SWS-4 sample location. Five soil samples were collected from a backhoe bucket from subsurface locations based on previous field 
screening locations from CAU 405. Both the depth of the trench and the sample interval was approximately 4.5 to $5 \mathrm{ft}$ bgs. Visual observations of the soil brought to the surface and the sidewalls/floor of the trench indicated neither debris nor stained soil was present. Field screening and observations did not indicate the presence of TPH-DRO. Figure A.7-1 shows the sample locations in relation to CAU 405 investigation locations.

Based on the October 2002 excavation and the historical investigation results, it was assumed that the TPH contamination was restricted to the immediate vicinity of the SWS-4 location to a depth of 4.5 to $5 \mathrm{ft} \mathrm{bgs}$, in an area of approximately 30 square feet $\left(\mathrm{ft}^{2}\right)$, with an approximate volume of $12 \mathrm{yd}^{3}$. On this basis, ROTC No. 1 to the CAIP was submitted for supplemental field activities that included defining the site boundaries by excavation and delineating the vertical limits of potential TPH-DRO. These excavation activities were conducted on March 3 and 4, 2003.

The supplemental field activities commenced with an excavation starting at a central location within the boundaries established in ROTC No. 1 to the CAIP. Initial field screening for TPH indicated that overburden soil and subsurface soil had FSRs above the FSL. The soil was stockpiled as IDW. When the excavation reached a depth of 5 to $7 \mathrm{ft} \mathrm{bgs,} \mathrm{stained} \mathrm{soil} \mathrm{and} \mathrm{burned}$ debris was encountered (see Figure A.7-2). At that time three characterization samples were collected and submitted for analysis to define potential COCs. Those results indicated that no COCs were present. Because the depth (greater than $9 \mathrm{ft} \mathrm{bgs)}$ and width of debris and staining was greater than anticipated and beyond the capability of the equipment, excavation activities were suspended pending decisions on the investigation strategy. Excavation activities resumed March 24, 2003, after ROTC No. 3 to the CAIP was implemented, which documents the change to the CAS footprint. The investigation continued by trenching several potholes within the CAS footprint to determine lateral extent of the burn pit materials. While two potholes were able to identify the eastern boundary of the CAS, Pothole \#2, which was located approximately $40 \mathrm{ft}$ from the open excavation, encountered observable TPH contamination in the subsurface along with stained debris and soil. Analytical results confirmed TPH concentrations above PALS existed in the southern portion of the CAS approximately 40 to $50 \mathrm{ft}$ south of the original CAU $405 \mathrm{SWS}-4$ location. 


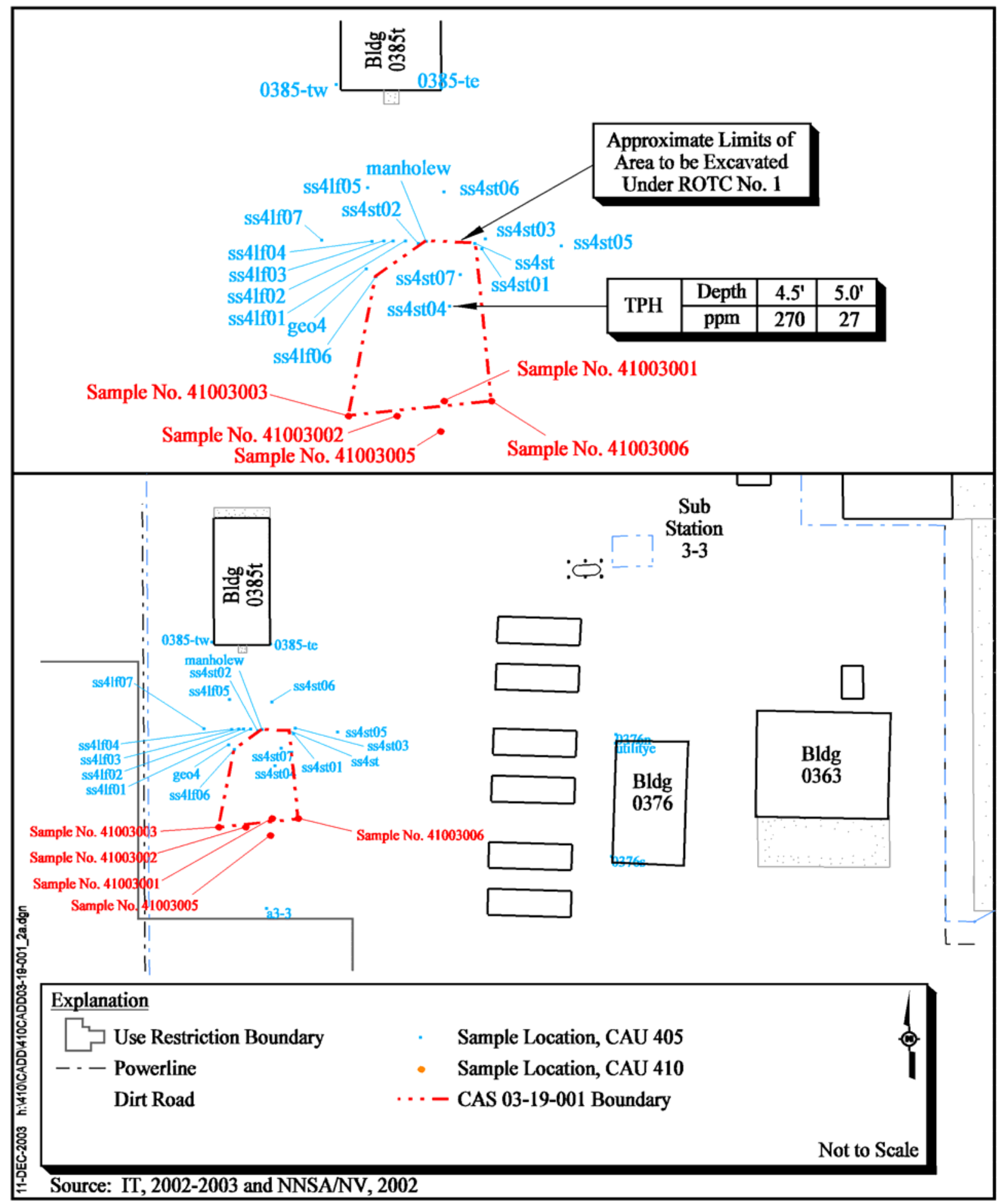

Figure A.7-1

Sample Location Map for Initial Investigation of CAS 03-19-001 


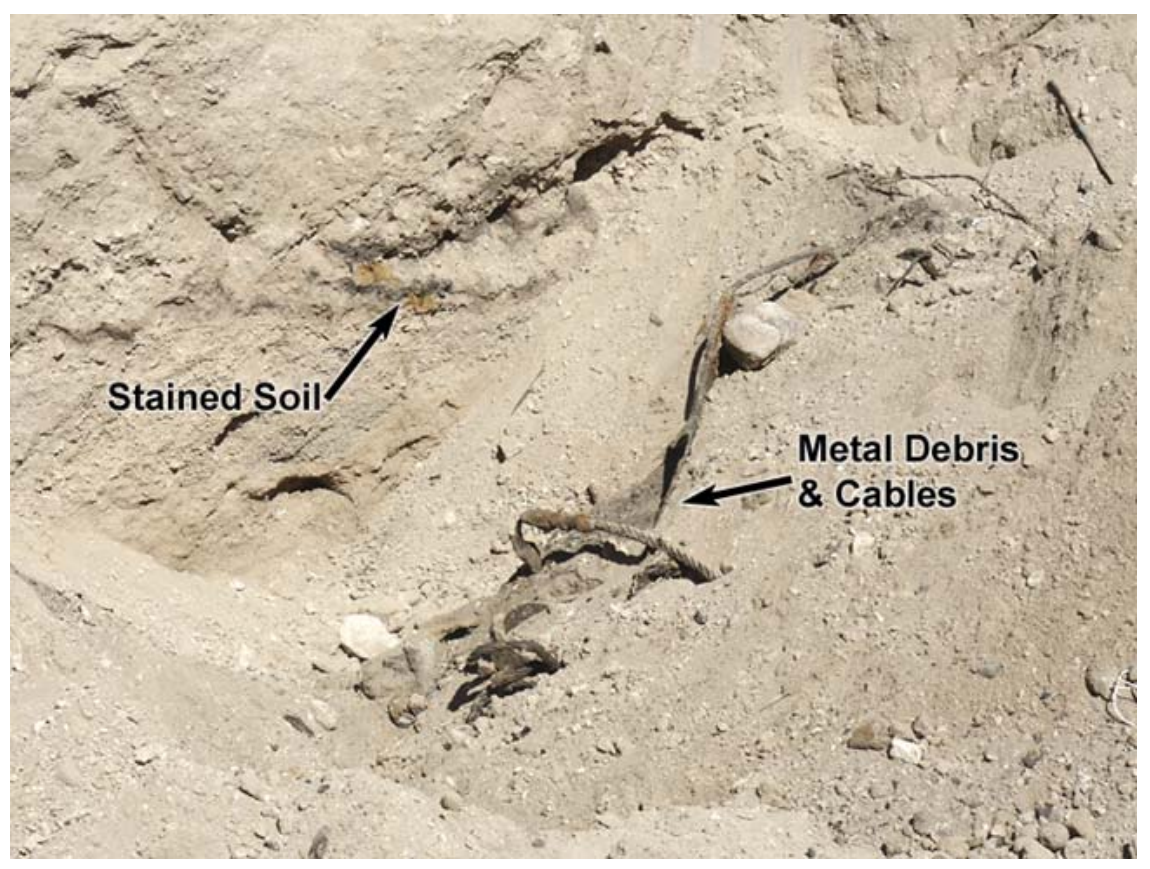

Figure A.7-2

CAS 03-19-001 Stained Soil

(Stained soil and debris visible within excavation, photo taken March 2003)

After drilling activities aided in defining vertical extent of the TPH contamination (see Section A.7.3.3), excavation resumed April 29, 2003, to further define the vertical and lateral boundaries of both the burn pit and TPH areas by collecting samples from the sidewalls and floor of the excavations. Based on the results of the borings, potholes, and FSRs, the northern boundary of TPH contamination within the burn pit was well defined thus becoming a focal point of separating the investigation into two distinct areas. As soil was removed from the subsurface to access sampling horizons, it was stockpiled separately based on visual and field-screening characteristics (i.e., hydrocarbon versus burned debris). Because initial analytical results indicated that soils and debris in the burn pit were not impacted by COPCs, excavation to delineate the boundaries resumed in the northern portion of the CAS (Figure A.7-3). Excavation into the TPH area commenced after confirming that the FSRs for sidewalls and floor of the burn pit area were below FSLs. Field screening for TPH was performed on various intervals along the sidewalls and floor of the TPH area to guide the excavation and select samples for laboratory analysis. Debris and staining was present in TPH soils at depths up to 12 to $13 \mathrm{ft}$ bgs. Upon completion of defining the vertical and lateral 


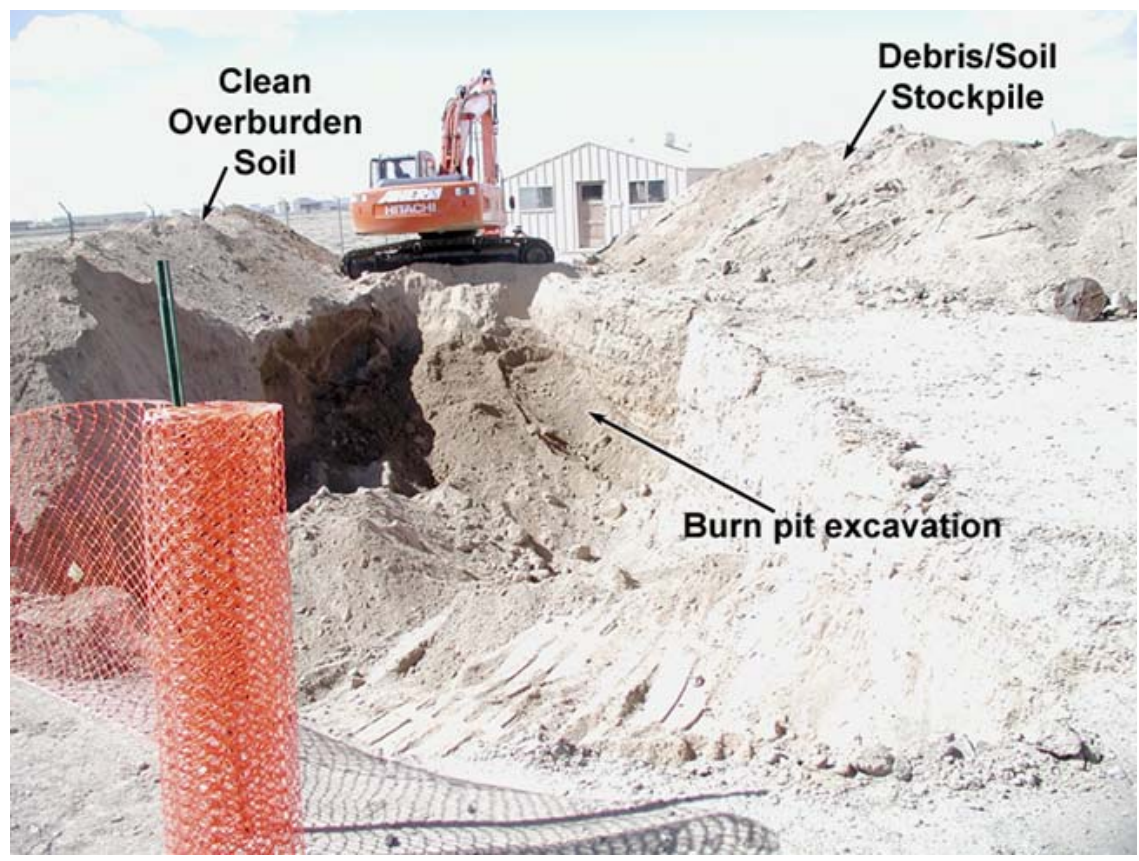

Figure A.7-3

CAS 03-19-001 Burn Pit

(View of completed burn pit excavation, photo taken April 2003)

extent of TPH contamination (see Figure A.7-4), all contaminated soil above PALs (confirmed by analytical results) and debris had been removed and stockpiled as IDW. Appendix D shows additional photos of the completed excavation.

The overall dimensions of the burn pit were approximately $60 \mathrm{by} 40 \mathrm{ft}$ and up to $15 \mathrm{ft}$ deep. The overall dimensions of the TPH area were approximately 20 by 40 by $17 \mathrm{ft}$ deep. The vertical plane of the TPH southern boundary is located approximately 2 to $3 \mathrm{ft}$ north of the CAU 424 use restriction. The final lateral limits of the excavation of the burn pit and TPH area are presented on Figure A.7-5. Figure A.7-6 is a more detailed sketch of the confirmation sample locations within the TPH excavation area.

\section{A.7.3.3 Hollow-Stem Auger Drilling}

Following the March 2003 excavation activities, hollow-stem auger (HSA) drilling was used to bound the extent of TPH-contaminated soils in the southern portion of the site and bound the extent 


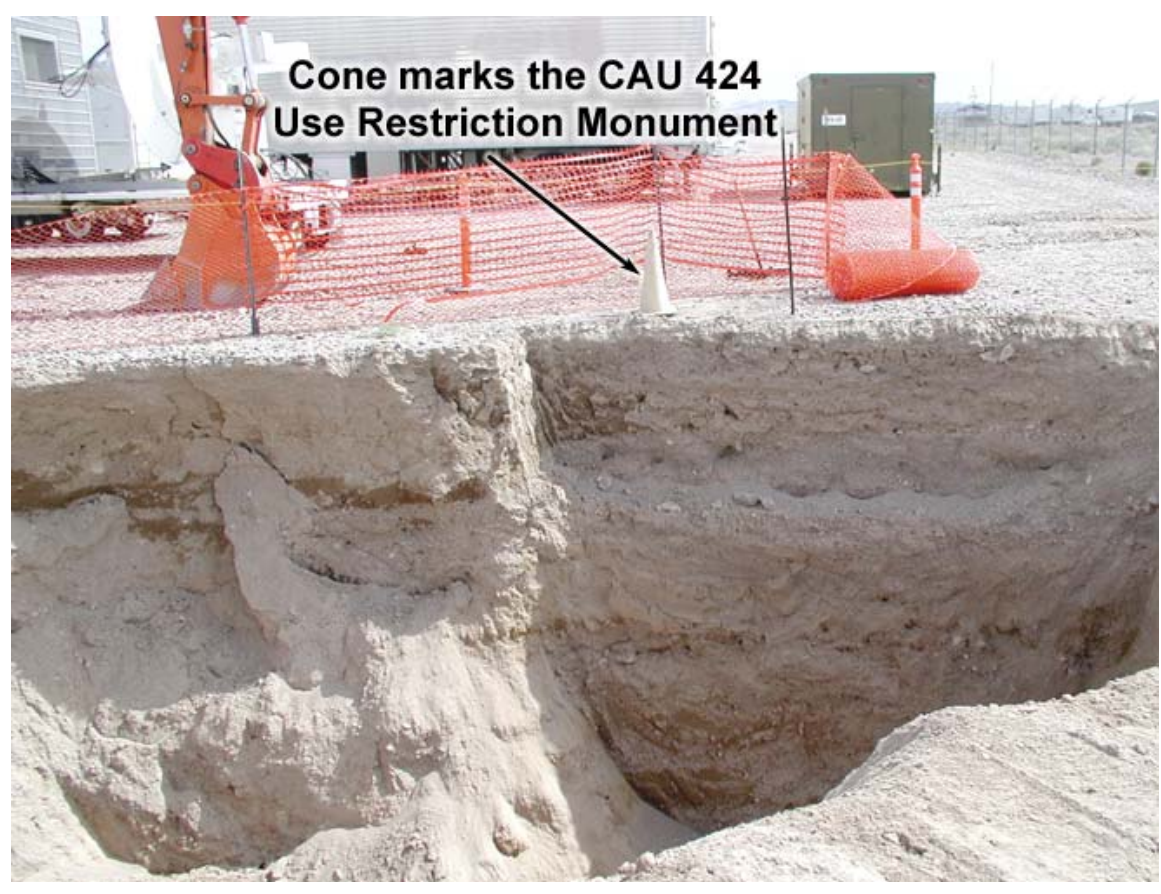

Figure A.7-4

CAS 03-19-001 TPH Area

(View of completed TPH excavation,

photo taken May 2003)

of potentially impacted soil for the remaining areas of the burn pit area. Decontaminated augers and drill pipe were used to drill to depths reaching up to $20 \mathrm{ft}$. Eighteen-inch split-spoon samplers were used to collect soil for sampling and boring descriptions. Observations were made of soil cuttings coming to the surface for debris and soil staining. A total of 10 borings were conducted at the site.

Soil boring B01 was drilled at the Pothole \#2 location and soil borings B02 through B05 were installed as step-out borings to vertically and laterally bound the TPH-DRO-impacted material. In each boring, once the vertical extent of TPH-DRO contamination was determined by field screening and visual observations, confirmation samples were collected beneath the TPH-DRO-impacted material. In borings with no indication of contamination, a sample was collected from the depth interval associated with TPH contamination in Pothole \#2 and Boring B01.

To guide additional excavation activities in the burn pit area, soil borings B06 through B10 were drilled to further delineate the lateral and vertical extent of the burn pit. Soil samples were collected 


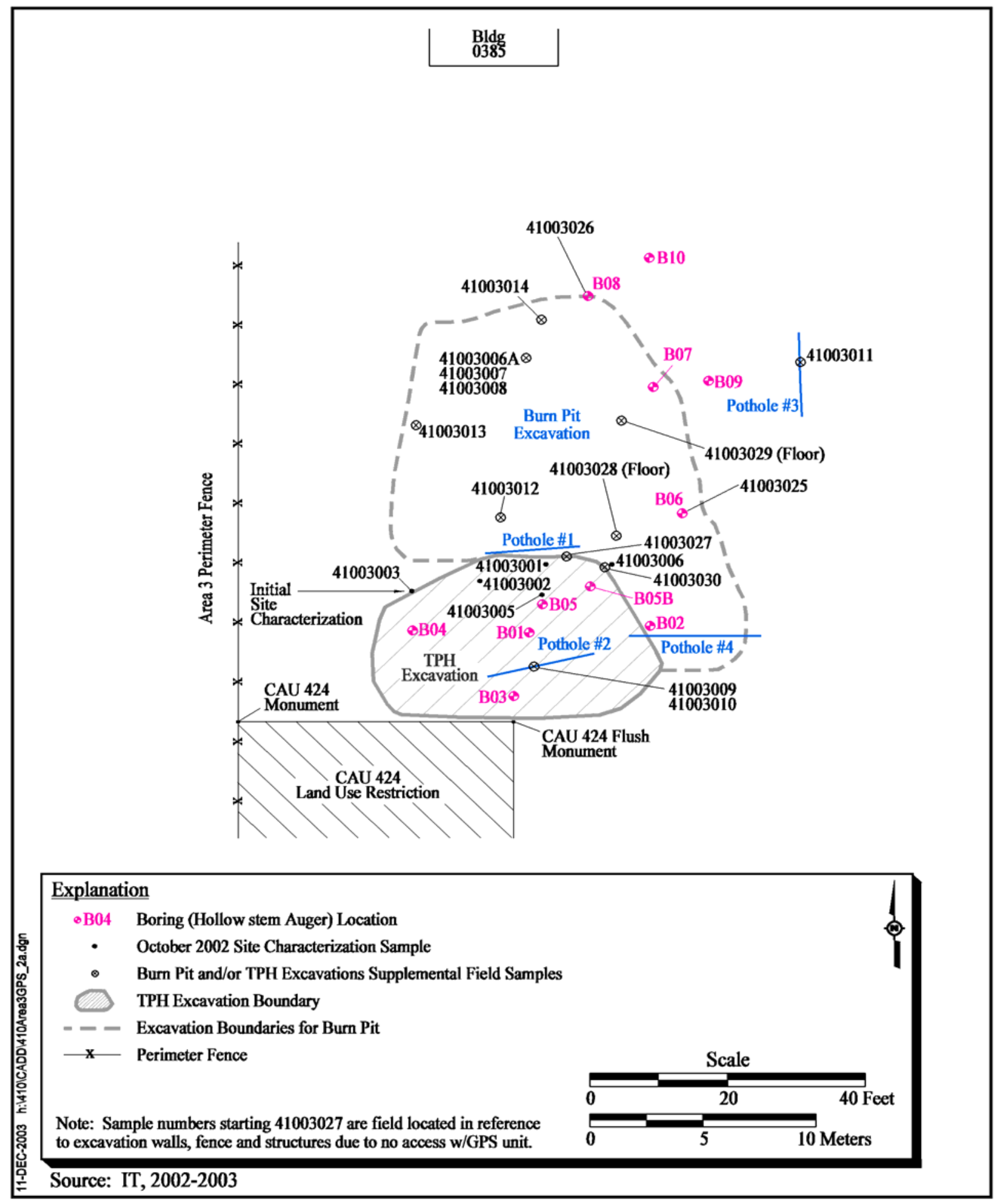

Figure A.7-5

General Site Layout and Sample Location Map after Supplemental Field Activities, CAS 03-19-001 


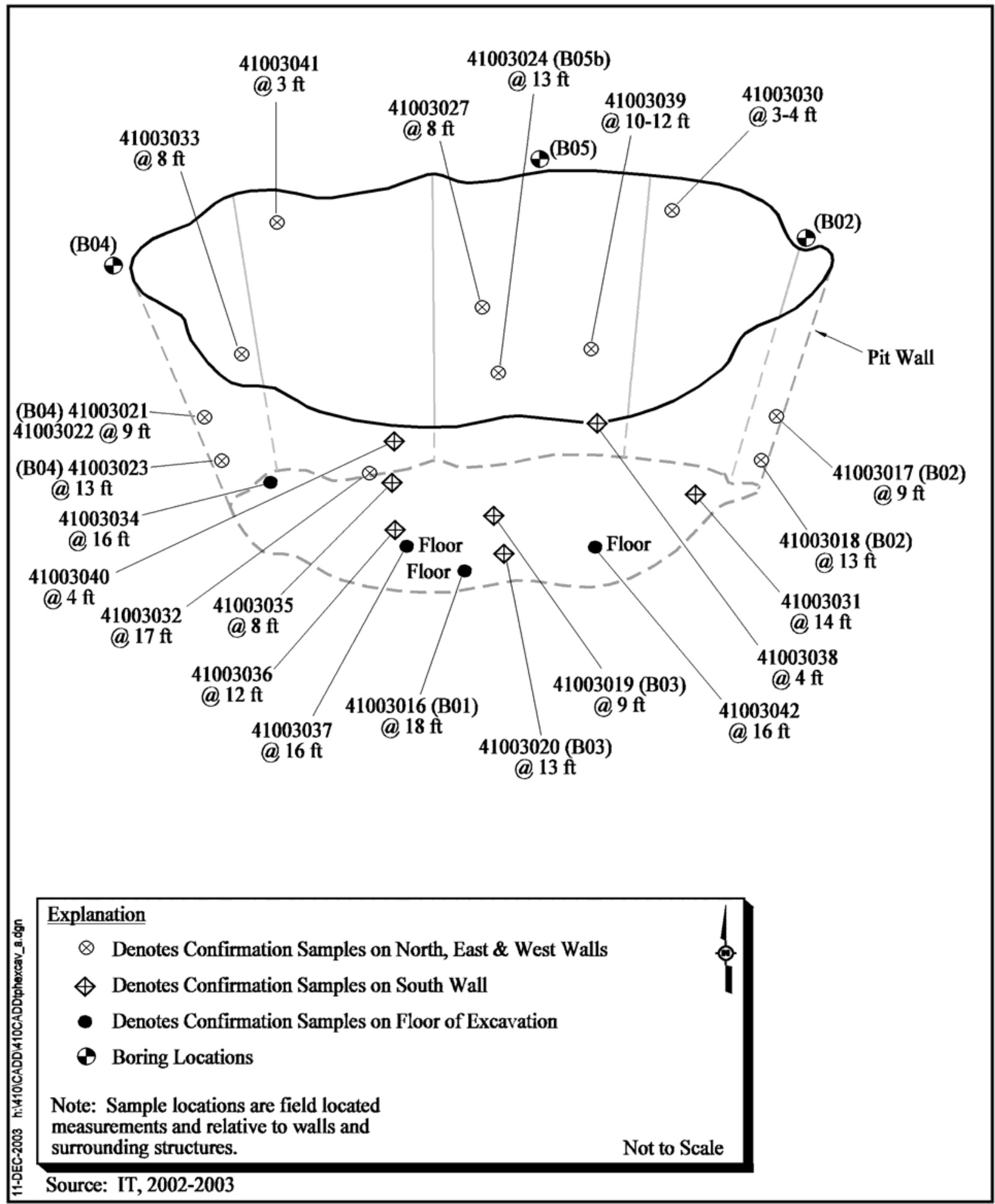

Figure A.7-6

Detailed Sketch of TPH Confirmation Sample Locations, CAS 03-19-001 
and submitted for laboratory analysis from borings B06 and B08 to confirm that TPH-DRO or other COPCs were not present at these locations. The subsurface geology was logged for each of the borings.

\section{A.7.3.4 Waste Characterization}

Stained soil and burned debris as well as TPH-contaminated waste (i.e., soil and debris) were separated and segregated into stockpiles as IDW during excavation activities. Any clean overburden soil as indicated by visual observations and field screening was also separated for use as backfill. A limited number of waste characterization samples were submitted for laboratory analyses. No verification samples of the ground surface was necessary as the TPH soil was stockpiled on plastic. The burn pit waste stockpile was shown to be nonhazardous and non-TPH contaminated so verification samples were not necessary. Details regarding the waste management and closure-type activities are provided in Appendix D.

\section{A.7.3.5 Sample Analysis}

The analytical results were compared to PALs for the TPH-DRO parameters during the initial October 2002 investigation. The analytical results for samples collected during the supplemental field activities conducted in March and April 2003 were compared to PALs for various combinations of the parameters including total VOCs, total SVOCs, total RCRA metals, HEs, total beryllium, gamma spectrometry, TPH-DRO and -GRO, PCBs, pesticides, herbicides, isotopic uranium, and isotopic plutonium.

\section{A.7.4 Analytes Detected Above MRL}

The analytical results detected at concentrations exceeding the correlated MRLs at this CAS are summarized in the following sections.

\section{A.7.4.1 Total SVOCs}

The total SVOC results for soil samples collected from CAS 03-19-001, which were detected above MRLs, are presented on Table A.7-3. Phenanthrene, the only analyte detected, does not have a 
defined PAL (NNSA/NV, 2002a). The soil associated with this sample was removed from the subsurface during characterization activities.

Table A.7-3

Soil Sample Results for Total SVOCs

Detected Above Minimum Reporting Limits at CAS 03-19-001

\begin{tabular}{|c|c|c|c|}
\hline \multirow{2}{*}{$\begin{array}{l}\text { Sample } \\
\text { Number }\end{array}$} & \multirow{2}{*}{$\begin{array}{l}\text { Sample } \\
\text { Location }\end{array}$} & \multirow{2}{*}{$\begin{array}{l}\text { Depth } \\
\text { (ft bgs) }\end{array}$} & Contaminants of Potential Concern $(\mu \mathrm{g} / \mathrm{kg})$ \\
\hline & & & Phenanthrene \\
\hline \multicolumn{3}{|c|}{ Preliminary Action Levels ${ }^{a}$} & $\mathbf{N I}$ \\
\hline$\overline{41003009}$ & $\overline{\mathrm{NA}}$ & $\overline{\mathrm{NA}}$ & $\overline{710}$ \\
\hline
\end{tabular}

aased on U.S. Environmental Protection Agency, Region 9 Preliminary Remediation Goals (PRGs) (EPA, 2000b)

$\mathrm{ft}$ bgs $=$ Feet below ground surface

$\mu \mathrm{g} / \mathrm{kg}=$ Micrograms per kilogram

NA $=$ Not applicable

$\mathrm{NI}=$ Not identified

\section{A.7.4.2 Total Metals}

The total metals results for soil samples collected from CAS 03-19-001, which were detected above MRLs, are presented on Table A.7-4. All total metals results are below PALs (NNSA/NV, 2002a).

\section{A.7.4.3 TPH-DRO}

The TPH-DRO results for soil samples collected from CAS 03-19-001, which were detected above MRLs, are presented on Table A.7-5. The TPH-DRO was detected above the PAL in soil samples 41003009 and 41003015 . These soil samples were collected to characterize soils during initial excavation and represent soils that were removed during soil excavation activities.

\section{A.7.4.4 PCBs}

The PCB results for soil samples collected from CAS 03-19-001, which were detected above MRLs, are presented on Table A.7-6. All PCB results are below PALs (NNSA/NV, 2002a). 
Table A.7-4

Soil Sample Results for Metals Detected Above Minimum Reporting Limits at CAS 03-19-001

(Page 1 of 2)

\begin{tabular}{|c|c|c|c|c|c|c|c|c|c|c|}
\hline \multirow{2}{*}{$\begin{array}{l}\text { Sample } \\
\text { Number }\end{array}$} & \multirow{2}{*}{$\begin{array}{l}\text { Sample } \\
\text { Location }\end{array}$} & \multirow{2}{*}{$\begin{array}{l}\text { Depth } \\
\text { (ft bgs) }\end{array}$} & \multicolumn{8}{|c|}{ Contaminants of Potential Concern (mg/kg) } \\
\hline & & & Arsenic & Barium & Beryllium & Cadmium & Chromium & Lead & Mercury & Silver \\
\hline \multicolumn{3}{|c|}{ Preliminary Action Levels $^{a}$} & $23^{b}$ & 100,000 & 2,200 & 810 & 450 & 750 & 610 & 10,000 \\
\hline$\overline{41003006 \mathrm{~A}}$ & \multirow{3}{*}{$\begin{array}{c}\text { North Sidewall - } \\
\text { Burn Pit }\end{array}$} & $\overline{74.5-5}$ & $\overline{\overline{8}}$ & $\overline{510}$ & $\overline{---}$ & $\overline{5.2}$ & $\overline{\overline{14}}$ & $\overline{\overline{170}}$ & $\overline{2.8}$ & $\overline{220}$ \\
\hline 41003007 & & $4.5-5$ & 4.5 & 120 & -- & 1.2 & 8.6 & 110 & 0.51 & 27 \\
\hline 41003008 & & $4.5-5$ & 4.4 & 100 & -- & 1.2 & 5.6 & 370 & 0.53 & 26 \\
\hline 41003009 & \multirow{2}{*}{ Pothole \#2 } & 7 & 4.2 & 94 & 0.59 & 5.1 & $12(\mathrm{~J})$ & 9 & $\overline{--}$ & 7.6 \\
\hline 41003010 & & $0-1$ & 4.2 & 10 & 0.57 & -- & $4.5(\mathrm{~J})$ & 8.6 & $\overline{--}$ & -- \\
\hline 41003011 & Pothole \#3 & 7 & 4 & 80 & $\overline{--}$ & $\overline{--}$ & 2.8 & 7.4 & $\overline{--}$ & -- \\
\hline 41003012 & $\begin{array}{c}\text { South Sidewall - } \\
\text { Burn Pit }\end{array}$ & $4-5$ & 4.6 & 110 & 0.58 & -- & 4.9 & 8.5 & -- & -- \\
\hline 41003013 & $\begin{array}{c}\text { West Sidewall - } \\
\text { Burn Pit }\end{array}$ & $6-7$ & 5.4 & 130 & 0.72 & -- & 6.5 & 9 & -- & -- \\
\hline 41003014 & $\begin{array}{c}\text { North Sidewall - } \\
\text { Burn Pit }\end{array}$ & $8-9$ & 4.7 & 110 & 0.56 & -- & 4.2 & 7.7 & -- & -- \\
\hline 41003015 & \multirow{2}{*}{ Boring B01 } & $12-13.5$ & 4.6 & 140 & -- & -- & 5.4 & 7.9 & -- & -- \\
\hline 41003016 & & $17-18.5$ & 5.5 & 160 & -- & $\overline{--}$ & 4.1 & 8.9 & $\overline{--}$ & $\overline{--}$ \\
\hline 41003017 & \multirow{2}{*}{ Boring B02 } & $8-9.5$ & 4 & 92 & -- & -- & 3.8 & 7.8 & -- & -- \\
\hline 41003018 & & $12-13.5$ & 5.4 & 170 & -- & -- & 6.3 & 11 & -- & -- \\
\hline 41003019 & \multirow{2}{*}{ Boring B03 } & $8-9.5$ & 4.7 & 110 & -- & -- & 7.1 & 8.5 & -- & -- \\
\hline 41003020 & & $12-13.5$ & 4.5 & 120 & -- & -- & 4.4 & 7.8 & -- & -- \\
\hline 41003021 & \multirow{3}{*}{ Boring B04 } & $8-9.5$ & 4.6 & 120 & -- & -- & 6.6 & 8.4 & -- & -- \\
\hline 41003022 & & $8-9.5$ & 4.5 & 110 & -- & -- & 8.6 & 8.1 & -- & -- \\
\hline 41003023 & & $12-13.5$ & 5.1 & 190 & -- & -- & 7.3 & 8.8 & $\overline{--}$ & $\overline{--}$ \\
\hline
\end{tabular}


Table A.7-4

Soil Sample Results for Metals Detected

Above Minimum Reporting Limits at CAS 03-19-001

(Page 2 of 2)

\begin{tabular}{|c|c|c|c|c|c|c|c|c|c|c|}
\hline \multirow{2}{*}{$\begin{array}{l}\text { Sample } \\
\text { Number }\end{array}$} & \multirow{2}{*}{$\begin{array}{l}\text { Sample } \\
\text { Location }\end{array}$} & \multirow{2}{*}{$\begin{array}{l}\text { Depth } \\
\text { (ft bgs) }\end{array}$} & \multicolumn{8}{|c|}{ Contaminants of Potential Concern $(\mathrm{mg} / \mathrm{kg})$} \\
\hline & & & Arsenic & Barium & Beryllium & Cadmium & Chromium & Lead & Mercury & Silver \\
\hline \multicolumn{3}{|c|}{ Preliminary Action Levels ${ }^{a}$} & $23^{b}$ & 100,000 & 2,200 & 810 & 450 & 750 & 610 & 10,000 \\
\hline 241003024 & Boring B05 & $\overline{112-13.5}$ & $\overline{5.2}$ & $\overline{240}$ & $\overline{---}$ & $\overline{---}$ & 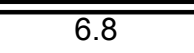 & $\overline{111}$ & $\overline{---}$ & $\overline{---}$ \\
\hline 41003025 & Boring B06 & $7.5-9$ & 3.9 & 130 & $\begin{array}{l}- \\
-\end{array}$ & -- & 3.8 & 7.3 & -- & $\overline{--}$ \\
\hline 41003026 & Boring B08 & $9.5-11$ & 5.3 & 81 & -- & -- & 10 & 6.5 & -- & $\begin{array}{l}- \\
-\end{array}$ \\
\hline 41003027 & $\begin{array}{c}\text { South Sidewall - } \\
\text { Burn Pit }\end{array}$ & $8-9$ & 4.5 & 100 & -- & -- & 5 & 8.5 & -- & -- \\
\hline 41003028 & \multirow{2}{*}{ Floor - Burn Pit } & $10-12$ & 3.7 & 150 & $\overline{--}$ & -- & 3.5 & 12 & -- & $\overline{--}$ \\
\hline 41003029 & & $10-12$ & 4 & 90 & -- & -- & 2.8 & 6.9 & -- & -- \\
\hline
\end{tabular}

aBased on U.S. Environmental Protection Agency, Region 9 Preliminary Remediation Goals (PRGs) (EPA, 2000b)

${ }^{\mathrm{b}}$ Based on background concentrations for metals. Background is considered the mean plus two standard deviation for sediment samples collected by the Nevada Bureau of Mines and Geology throughout the Nevada Test and Training Range (NBMG, 1998; Moore, 1999).

$\mathrm{ft}$ bgs $=$ Feet below ground surface

$\mathrm{mg} / \mathrm{kg}=$ Milligrams per kilogram

-- = Not detected above minimum reporting limits

$\mathrm{J}=$ Estimated value. Qualifier added to laboratory data; record accepted. Serial dilution \%D outside control limits. Matrix effects may exist.

NA $=$ Not applicable 
Table A.7-5

Soil Sample Results for TPH-DRO

Detected Above Minimum Reporting Limits at CAS 03-19-001

\begin{tabular}{|c|c|c|c|}
\hline \multirow{2}{*}{$\begin{array}{l}\text { Sample } \\
\text { Number }\end{array}$} & \multirow{2}{*}{$\begin{array}{l}\text { Sample } \\
\text { Location }\end{array}$} & \multirow{2}{*}{$\begin{array}{l}\text { Depth } \\
\text { (ft bgs) }\end{array}$} & Contaminants of Potential Concern (mg/kg) \\
\hline & & & Diesel-Range Organics \\
\hline \multicolumn{3}{|c|}{ Preliminary Action Levels ${ }^{a}$} & 100 \\
\hline $4 \overline{41003007}$ & \multirow{2}{*}{$\begin{array}{c}\text { North Sidewall - } \\
\text { Burn Pit }\end{array}$} & $\overline{4.5-5}$ & $\overline{31(\mathrm{~J})^{6}}$ \\
\hline 41003008 & & $4.5-5$ & $44(\mathrm{~J})^{\mathrm{b}}$ \\
\hline 41003009 & Pothole \#2 & 7 & $1,100(D)$ \\
\hline 41003015 & Boring B01 & $12-13.5$ & $630(\mathrm{D})$ \\
\hline 41003029 & Floor - Burn Pit & $10-12$ & $27(J)^{b}$ \\
\hline 41003031 & $\begin{array}{c}\text { South Sidewall - } \\
\text { TPH Pit }\end{array}$ & $12-14$ & $43(\mathrm{~J})^{\mathrm{b}}$ \\
\hline 41003032 & $\begin{array}{c}\text { North Sidewall - } \\
\text { TPH Pit }\end{array}$ & $16-17$ & $28(J)^{b}$ \\
\hline 41003040 & $\begin{array}{c}\text { South Sidewall - } \\
\text { TPH Pit }\end{array}$ & $3-4$ & $62(J)^{c}$ \\
\hline 41003042 & Floor - TPH Pit & $14-16$ & $54(\mathrm{~J})^{c}$ \\
\hline
\end{tabular}

aBased on Nevada Administrative Code; Contamination of soil: Establishment of Action Levels (NAC, 2002)

${ }^{\mathrm{b}} \mathrm{Qualifier}$ added to laboratory data; record accepted. Total extractable petroleum hydrocarbons result quantitated from diesel standard calibration.

${ }^{\circ}$ Qualifier added to laboratory data; record accepted. Total extractable petroleum hydrocarbons result quantitated from diesel standard calibration. Improper packaging of sample container/custody tape not used.

$\mathrm{ft}$ bgs $=$ Feet below ground surface

$\mathrm{mg} / \mathrm{kg}=$ Milligrams per kilogram

$\mathrm{D}=$ Dilution run. Initial run outside linear range of instrument.

$\mathrm{J}=$ Estimated value

Table A.7-6

Soil Sample Results for PCBs Detected Above Minimum Reporting Limits at CAS 03-19-001

\begin{tabular}{||c|c|c|c||}
\hline \multirow{2}{*}{$\begin{array}{c}\text { Sample } \\
\text { Number }\end{array}$} & \multirow{2}{*}{$\begin{array}{c}\text { Sample } \\
\text { Location }\end{array}$} & $\begin{array}{c}\text { Depth } \\
\text { (ft bgs) }\end{array}$ & Contaminants of Potential Concern $(\mu \mathbf{g} / \mathbf{k g})$ \\
\cline { 4 - 5 } & & & Aroclor-1260 \\
\hline \multicolumn{2}{|c|}{ Preliminary Action Levels } \\
\end{tabular}

aBased on U.S. Environmental Protection Agency, Region 9 Preliminary Remediation Goals (PRGs) (EPA, 2000b)

$\mathrm{ft}$ bgs $=$ Feet below ground surface

$\mu \mathrm{g} / \mathrm{kg}=$ Micrograms per kilogram 


\section{A.7.4.5 Pesticides}

The pesticide results for soil samples collected from CAS 03-19-001, which were detected above MRLs, are presented on Table A.7-7. All pesticide results are below PALs (NNSA/NV, 2002a).

Table A.7-7

Soil Sample Results for Pesticides

Detected Above Minimum Reporting Limits at CAS 03-19-001

\begin{tabular}{||c|c|c|c|c|}
\hline \multirow{2}{*}{$\begin{array}{c}\text { Sample } \\
\text { Number }\end{array}$} & \multirow{2}{*}{$\begin{array}{c}\text { Sample } \\
\text { Location }\end{array}$} & $\begin{array}{c}\text { Depth } \\
\text { (ft bgs) }\end{array}$ & \multicolumn{2}{|c|}{ Contaminants of Potential Concern $(\mu \mathrm{g} / \mathrm{kg})$} \\
\cline { 3 - 5 } & & Dieldrin & Gamma-BHC (Lindane) \\
\hline \multicolumn{2}{|c|}{ Preliminary Action Levels } & $\mathbf{2}$ & $\mathbf{1 5 0}$ & $7.1(\mathrm{~J})$ \\
\hline \hline 41003009 & Pothole \#2 & 7 & $1.9(\mathrm{~J})$ & \\
\hline
\end{tabular}

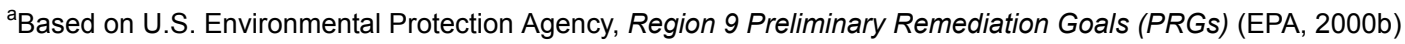

$\mathrm{ft}$ bgs $=$ Feet below ground surface

$\mu \mathrm{g} / \mathrm{kg}=$ Micrograms per kilogram

$\mathrm{J}=$ Estimated value. Qualifier added to laboratory data; record accepted. Surrogate recovery exceeded the upper limits.

\section{A.7.4.6 Isotopic Uranium}

The isotopic uranium results for soil samples collected from CAS 03-19-001, which were detected above MRLs, are presented on Table A.7-8. All isotopic uranium results are below PALs (NNSA/NV, 2002a).

\section{A.7.4.7 Gamma-Emitting Radionuclides}

The gamma-emitting radionuclide results for soil samples collected from CAS 03-19-001, which were detected above MRLs, are presented on Table A.7-9. Except for potassium-40, all gamma-emitting radionuclide results are below PALs (NNSA/NV, 2002a). Potassium-40 was detected at concentrations exceeding the PALs; however, potassium- 40 analytical results were evaluated using the normalized difference test as discussed in Section A.2.7. The potassium-40 concentrations are considered indistinguishable from the PAL. 
Table A.7-8

Soil Sample Results for Isotopic Uranium

Detected Above Minimum Reporting Limits at CAS 03-19-001

\begin{tabular}{|c|c|c|c|c|c|}
\hline \multirow{2}{*}{$\begin{array}{l}\text { Sample } \\
\text { Number }\end{array}$} & \multirow{2}{*}{$\begin{array}{l}\text { Sample } \\
\text { Locations }\end{array}$} & \multirow{2}{*}{$\begin{array}{l}\text { Depth } \\
\text { (ft bgs) }\end{array}$} & \multicolumn{3}{|c|}{ Contaminants of Potential Concern (pCi/g) } \\
\hline & & & Uranium-234 & Uranium-235 & Uranium-238 \\
\hline \multicolumn{3}{|c|}{ Preliminary Action Levels ${ }^{a}$} & 3.47 & 0.07 & 3.47 \\
\hline 41003009 & \multirow{2}{*}{ Pothole \#2 } & 7 & $1.15 \pm 0.21$ & $0.071 \pm 0.036$ & $0.99 \pm 0.18$ \\
\hline 41003010 & & $0-1$ & $1.21 \pm 0.21$ & $0.071 \pm 0.035$ & $1.12 \pm 0.20$ \\
\hline 41003011 & Pothole \#3 & 7 & $1.04 \pm 0.18$ & $0.073 \pm 0.034$ & $1.07 \pm 0.18$ \\
\hline 41003012 & $\begin{array}{c}\text { South Sidewall - } \\
\text { Burn Pit }\end{array}$ & $4-5$ & $1.31 \pm 0.21$ & -- & $1.28 \pm 0.21$ \\
\hline 41003013 & $\begin{array}{c}\text { West Sidewall - } \\
\text { Burn Pit }\end{array}$ & $6-7$ & $1.33 \pm 0.21$ & $0.098 \pm 0.040$ & $1.16 \pm 0.19$ \\
\hline 41003014 & $\begin{array}{c}\text { North Sidewall - } \\
\text { Burn Pit }\end{array}$ & $8-9$ & $1.1 \pm 0.18$ & $0.071 \pm 0.035$ & $1.3 \pm 0.21$ \\
\hline
\end{tabular}

aBased on background concentration listed in Environmental Monitoring Report for the Proposed Ward Valley, California, Low-Level Radioactive Waste (LLRW) Facility (US Ecology and Atlan-Tech, 1991)

${ }^{\mathrm{b}}$ Based on background concentration listed or derived in Off-Site Radiation Exposure Review Project, Phase II Soil Program (McArthur and Miller, 1989)

$\mathrm{ft}$ bgs $=$ Feet below ground surface

$\mathrm{pCi} / \mathrm{g}=$ Picocuries per gram

$--=$ Not detected above minimum reporting limits

\section{A.7.5 Contaminants of Concern}

The only COC identified in subsurface soil of CAS 03-19-001 was TPH-DRO found in the southern end of the CAS footprint referred to as the TPH area. Based on the analytical results of the final confirmation samples, there are no COCs identified in the remaining soil.

\section{A.7.6 Nature and Extent of Contamination}

The nature and extent of TPH contamination was delineated through sample collection by excavation and drilling activities. The vertical and lateral extent of debris and stained soil associated with both the burn pit and TPH areas was delineated through visual observations while excavating to access sample horizons. Due to the nature of the investigation in which TPH-contaminated soil and soil mixed with debris was stockpiled and disposed as IDW, there is no remaining TPH contamination or debris at this CAS. This is confirmed by visual observations and confirmation sample results. 
Table A.7-9

Soil Sample Results for Gamma-Emitting Radionuclides Detected Above Minimum Reporting Limits at CAS 03-19-001

(Page 1 of 2)

\begin{tabular}{|c|c|c|c|c|c|c|c|c|}
\hline \multirow{2}{*}{$\begin{array}{l}\text { Sample } \\
\text { Number }\end{array}$} & \multirow{2}{*}{$\begin{array}{l}\text { Sample } \\
\text { Location }\end{array}$} & \multirow{2}{*}{$\begin{array}{l}\text { Depth } \\
\text { (ft bgs) }\end{array}$} & \multicolumn{6}{|c|}{ Contaminants of Potential Concern $(\mathrm{pCi} / \mathrm{g})$} \\
\hline & & & Actinium-228 & Bismuth-214 & Lead-212 & Lead-214 & Potassium-40 & Thallium-208 \\
\hline \multicolumn{3}{|c|}{ Preliminary Action Levels } & $3.64^{a}$ & $3.47^{a}$ & $3.64^{a}$ & $3.47^{a}$ & $30.7^{\mathrm{b}}$ & $3.38^{a}$ \\
\hline $41003006 \mathrm{~A}$ & \multirow{3}{*}{$\begin{array}{c}\text { North Sidewall - } \\
\text { Burn Pit }\end{array}$} & $4.5-5$ & $1.68 \pm 0.51$ & $1.18 \pm 0.38$ & $1.51 \pm 0.36$ & $1.29 \pm 0.33$ & $28.5 \pm 6.2$ & $0.66 \pm 0.21$ \\
\hline 41003007 & & $4.5-5$ & $1.92 \pm 0.71$ & $0.97 \pm 0.40$ & $1.55 \pm 0.39$ & $0.97 \pm 0.30$ & $26 \pm 6.3$ & $0.59 \pm 0.22$ \\
\hline 41003008 & & $4.5-5$ & $1.5 \pm 0.45$ & $0.87 \pm 0.31$ & $1.82 \pm 0.36$ & $1.18 \pm 0.30$ & $32.8 \pm 6.3$ & $0.42 \pm 0.14$ \\
\hline 41003009 & \multirow{2}{*}{ Pothole \#2 } & 7 & $1.44 \pm 0.42$ & $1.13 \pm 0.31$ & $1.66 \pm 0.35$ & $1.41 \pm 0.30$ & $27.7 \pm 5.4$ & $0.56 \pm 0.15$ \\
\hline 41003010 & & $0-1$ & $1.77 \pm 0.49$ & $1.07 \pm 0.32$ & $2.27 \pm 0.45$ & $1.24 \pm 0.29$ & $25.6 \pm 5.4$ & $0.66 \pm 0.18$ \\
\hline 41003011 & Pothole \#3 & 7 & $1.61 \pm 0.38$ & $0.94 \pm 0.24$ & $1.98 \pm 0.38$ & $1.05 \pm 0.24$ & $27.1 \pm 5.1$ & $0.65 \pm 0.16$ \\
\hline 41003012 & $\begin{array}{c}\text { South Sidewall - } \\
\text { Burn Pit }\end{array}$ & $4-5$ & $1.78 \pm 0.41$ & $1.12 \pm 0.27$ & $1.73 \pm 0.34$ & $1.35 \pm 0.28$ & $30.1 \pm 5.6$ & $0.64 \pm 0.16$ \\
\hline 41003013 & $\begin{array}{c}\text { West Sidewall - } \\
\text { Burn Pit }\end{array}$ & $6-7$ & $1.64 \pm 0.43$ & $1.42 \pm 0.36$ & $1.92 \pm 0.39$ & $1.38 \pm 0.31$ & $26.8 \pm 5.3$ & $0.68 \pm 0.18$ \\
\hline 41003014 & $\begin{array}{c}\text { North Sidewall - } \\
\text { Burn Pit }\end{array}$ & $8-9$ & $1.63 \pm 0.39$ & $1.11 \pm 0.28$ & $1.88 \pm 0.37$ & $1.22 \pm 0.27$ & $27 \pm 5.2$ & $0.42 \pm 0.12$ \\
\hline 41003015 & \multirow{2}{*}{ Boring B01 } & $12-13.5$ & $1.68 \pm 0.48$ & $1.11 \pm 0.37$ & $2.08 \pm 0.42$ & $1.48 \pm 0.34$ & $33.3 \pm 6.4$ & $0.57 \pm 0.17$ \\
\hline 41003016 & & $17-18.5$ & $2.21 \pm 0.76$ & -- & $1.62 \pm 0.41$ & $1.09 \pm 0.35$ & $30.5 \pm 7.0$ & $0.73 \pm 0.25$ \\
\hline 41003017 & \multirow{2}{*}{ Boring B02 } & $8-9.5$ & $1.23 \pm 0.40$ & $0.89 \pm 0.33$ & $1.61 \pm 0.33$ & $0.67 \pm 0.22$ & $25 \pm 5.0$ & $0.37 \pm 0.13$ \\
\hline 41003018 & & $12-13.5$ & -- & -- & $2.32 \pm 0.51$ & $1.42 \pm 0.41$ & $34.2 \pm 7.8$ & $0.63 \pm 0.25$ \\
\hline 41003019 & \multirow{2}{*}{ Boring B03 } & $8-9.5$ & -- & -- & $2.12 \pm 0.48$ & $1.28 \pm 0.36$ & $27.6 \pm 6.8$ & -- \\
\hline 41003020 & & $12-13.5$ & $1.89 \pm 0.52$ & $1.1 \pm 0.37$ & $1.73 \pm 0.36$ & $1.17 \pm 0.30$ & $32.6 \pm 6.3$ & $0.58 \pm 0.17$ \\
\hline 41003021 & \multirow{3}{*}{ Boring B04 } & $8-9.5$ & -- & $1.34 \pm 0.50$ & $2.26 \pm 0.51$ & $0.91 \pm 0.32$ & $27.9 \pm 7.3$ & -- \\
\hline 41003022 & & $8-9.5$ & -- & $1.19 \pm 0.45$ & $1.8 \pm 0.45$ & $0.84 \pm 0.31$ & $29.2 \pm 6.8$ & -- \\
\hline 41003023 & & $12-13.5$ & $1.98 \pm 0.55$ & $1.09 \pm 0.39$ & $2 \pm 0.41$ & $1.2 \pm 0.31$ & $33.6 \pm 6.6$ & $0.5 \pm 0.16$ \\
\hline
\end{tabular}


Table A.7-9

Soil Sample Results for Gamma-Emitting Radionuclides Detected Above Minimum Reporting Limits at CAS 03-19-001

(Page 2 of 2)

\begin{tabular}{|c|c|c|c|c|c|c|c|c|}
\hline \multirow{2}{*}{$\begin{array}{l}\text { Sample } \\
\text { Number }\end{array}$} & \multirow{2}{*}{$\begin{array}{l}\text { Sample } \\
\text { Location }\end{array}$} & \multirow{2}{*}{$\begin{array}{l}\text { Depth } \\
\text { (ft bgs) }\end{array}$} & \multicolumn{6}{|c|}{ Contaminants of Potential Concern (pCi/g) } \\
\hline & & & Actinium-228 & Bismuth-214 & Lead-212 & Lead-214 & Potassium-40 & Thallium-208 \\
\hline \multicolumn{3}{|c|}{ Preliminary Action Levels } & $3.64^{a}$ & $3.47^{a}$ & $3.64^{a}$ & $3.47^{a}$ & $30.7^{b}$ & $3.38^{a}$ \\
\hline 241003024 & Boring B05 & $\overline{112-13.5}$ & $\overline{1.63 \pm 0.61}$ & $\overline{0.98 \pm 0.40}$ & $1.79 \pm 0.45$ & $1.22 \pm 0.35$ & $29.1 \pm 6.7$ & $\overline{0.49 \pm 0.19}$ \\
\hline 41003025 & Boring B06 & $7.5-9$ & $1.76 \pm 0.58$ & $1.03 \pm 0.40$ & $1.99 \pm 0.46$ & $1.47 \pm 0.39$ & $35.3 \pm 7.7$ & $0.58 \pm 0.21$ \\
\hline 41003026 & Boring B08 & $9.5-11$ & -- & $1.31 \pm 0.45$ & $1.86 \pm 0.45$ & $1.38 \pm 0.38$ & $32.5 \pm 7.4$ & $0.42 \pm 0.18$ \\
\hline 41003027 & $\begin{array}{c}\text { South Sidewall - } \\
\text { Burn Pit }\end{array}$ & $8-9$ & $1.59 \pm 0.58$ & $1.05 \pm 0.41$ & $1.55 \pm 0.38$ & $1.17 \pm 0.33$ & $26.6 \pm 6.1$ & $0.62 \pm 0.22$ \\
\hline 41003028 & \multirow{2}{*}{ Floor - Burn Pit } & $10-12$ & $1.19 \pm 0.45$ & $1.41 \pm 0.42$ & $1.65 \pm 0.38$ & $1.1 \pm 0.30$ & $29.6 \pm 6.3$ & $0.58 \pm 0.19$ \\
\hline 41003029 & & $10-12$ & $1.85 \pm 0.60$ & $0.93 \pm 0.37$ & $1.4 \pm 0.37$ & $1.03 \pm 0.31$ & $31 \pm 7.0$ & $0.63 \pm 0.21$ \\
\hline
\end{tabular}

${ }^{a}$ Based on background concentration reported in Environmental Monitoring Report for the Proposed Ward Valley, California, Low-Level Radioactive Waste (LLRW) Facility (US Ecology and Atlan-Tech, 1991)

${ }^{\mathrm{b}}$ Based on background concentration listed or derived in Off-Site Radiation Exposure Review Project, Phase II Soil Program (McArthur and Miller, 1989)

$\mathrm{ft}$ bgs $=$ Feet below ground surface

$\mathrm{pCi} / \mathrm{g}=$ Picocuries per gram

-- = Not detected above minimum reporting limits

$\mathrm{NA}=$ Not applicable 


\section{A.7.7 Revised Conceptual Site Model}

The configuration and scope of CAS 03-19-001 was inconsistent with the historical information; however, there were no variations to the CSM with regards to the target population, source area, contaminant migration, or exposure pathways. 


\section{A.8.0 Quality Assurance}

This section contains a summary of the QA/QC measures implemented during the sampling, analysis, and investigation activities for CAU 410 corrective action investigation. The following sections of this appendix discuss the data validation process and the quality control samples. Appendix B provides a detailed evaluation of the DQIs of precision, accuracy, completeness, representativeness, and comparability for analytical results.

Laboratory analyses were conducted for samples used in the decision-making process to provide a quantitative measurement of any COPCs present. The QA/QC was implemented for all laboratory samples including documentation, data verification and validation of analytical results, and affirmation of DQI requirements related to laboratory analysis. Detailed information regarding the QA program is contained in the Industrial Sites QAPP (NNSA/NV, 2002b).

\section{A.8.1 Data Validation}

Data validation was performed in accordance with the Industrial Sites QAPP (NNSA/NV, 2002b) and approved procedures. All laboratory data from samples collected and analyzed for CAU 410 were evaluated for data quality according to the U.S. Environmental Protection Agency (EPA) Functional Guidelines (EPA, 1994a and 2000a). These guidelines are implemented in a tiered process and are presented in Section A.8.1.1 through Section A.8.1.3. Data were reviewed to ensure that samples were appropriately processed and analyzed, and the results passed data-validation criteria. Documentation of the data qualifications resulting from these reviews is retained in project files as a hard copy and electronic media.

One hundred percent of the data analyzed as part of this investigation were subjected to Tier I and Tier II evaluations. A Tier III evaluation was performed on 11 samples.

\section{A.8.1.1 Tier I Evaluation}

Tier I evaluation for both chemical and radiological analysis examines (but is not limited to):

- Sample count/type consistent with chain of custody

- Analysis count/type consistent with chain of custody 
- Correct sample matrix

- Significant problems stated in cover letter or case narrative

- Completeness of certificates of analysis

- Completeness of contract laboratory program (CLP) or CLP-like packages

- Completeness of signatures, dates, and times on chain of custody

- Condition-upon-receipt variance form included

- Requested analyses performed on all samples

- Date received/analyzed given for each sample

- Correct concentration units indicated

- Electronic data transfer supplied

- Results reported for field and laboratory QC samples

- Whether or not the deliverable met the overall objectives of the project

- Proper field documentation accompanies project packages

\section{A.8.1.2 Tier II Evaluation}

Tier II evaluation for both chemical and radiological analysis examines, but is not limited to, the following areas.

\section{Chemical:}

- Correct detection limits achieved

- Sample date, preparation date, and analysis date for each sample

- Holding time criteria met

- QC batch association for each sample

- Cooler temperature upon receipt

- Sample $\mathrm{pH}$ for aqueous samples, as required

- Detection limits properly adjusted for dilution, as required

- Blank contamination evaluated and applied to sample results/qualifiers

- Matrix spike/matrix spike duplicate (MS/MSD) percent recovery $(\% \mathrm{R})$ and relative percent difference (RPDs) evaluated and applied to laboratory results/qualifiers

- Field duplicate RPDs evaluated using professional judgement and applied to laboratory results/qualifiers

- Laboratory duplicate RPDs evaluated and applied to laboratory results/qualifiers

- Surrogate \%Rs evaluated and applied to laboratory results/qualifiers

- Laboratory control sample \%R evaluated and applied to laboratory results/qualifiers 
- Initial and continuing calibration evaluated and applied to laboratory results/qualifiers

- Internal standard evaluated and applied to laboratory results/qualifiers

- Mass spectrometer tuning criteria

- Organic compound quantitation

- Inductively coupled plasma (ICP) interference check sample evaluation

- Graphite furnace atomic absorption quality control

- ICP serial dilution effects

- Recalculation of 10 percent of laboratory results from raw data

\section{Radioanalytical:}

- Correct detection limits achieved

- Blank contamination evaluated and applied to sample results/qualifiers

- Certificate of Analysis consistent with data package documentation

- Quality control sample results (duplicates, laboratory control samples, laboratory blanks) evaluated and applied to laboratory result qualifiers

- Sample results, error, and minimum detectable activity evaluated and applied to laboratory result qualifiers

- Detector system calibrated to National Institute for Standards and Technology (NIST)-traceable sources

- Calibration sources preparation was documented, demonstrating proper preparation and appropriateness for sample matrix, emission energies, and concentrations

- Detector system response to daily, weekly, and monthly background and calibration checks, which may include peak energy, peak centroid, peak full-width half-maximum, and peak efficiency, depending on the detection system

- Tracers NIST-traceable, appropriate for the analysis performed, and recoveries that met QC requirements

- Documentation of all QC sample preparation complete and properly performed

- QC sample results (e.g., calibration source concentration, percent recovery, and RPD) verified

- Spectra lines, emissions, particle energies, peak areas, and background peak areas support the identified radionuclide and its concentration

- Recalculation of 10 percent of laboratory results from raw data 


\section{A.8.1.3 Tier III Evaluation}

A Tier III evaluation looks at all the items evaluated in the Tier II evaluation, but for only a limited number of samples (typically 5 percent). It serves as a check on the Tier II process. The Tier III review includes the additional evaluations:

\section{Chemical:}

- Recalculation of laboratory results from raw data

\section{Radioanalytical:}

- Radionuclides and their concentration appropriate considering their decay schemes and half-lives

- Each identified line in spectra verified against emission libraries and calibration results

- Independent identification of spectra lines, area under the peaks, and quantification of radionuclide concentration in a random number of sample results

- Recalculation of laboratory results from raw data

A Tier III review of 11 samples was conducted by TechLaw, Inc. in Lakewood, Colorado. The qualifiers for the samples analyzed for radiochemical analysis did not change based on the Tier III review. The qualifier for chemical analysis regarding one sample (410AL517) was changed for lead based on the review, lead results should have been estimated at the Tier II level. This review has been reflected for that sample delivery group (SDG). Additionally, the 19 other samples within the SDG were also changed to reflect the estimated value based on the Tier III review.

\section{A.8.2 Quality Control Samples}

There were 30 trip blanks, 7 field blanks, 3 source blanks, 3 equipment rinsate blanks, 5 MS/MSD, and 11 field duplicates collected and submitted for laboratory analysis as shown in CAS-specific Tables A.3-1, A.4-1, A.5-1, A.6-1, and A.7-1. The quality control samples and duplicates were assigned individual sample numbers and sent to the laboratory "blind." Additional samples were selected by the laboratory to be analyzed as laboratory duplicates. Documentation related to the collection and analysis of these samples is retained in project files. 


\section{A.8.2.1 Field Quality Control Samples}

Review of the field-blank analytical data for the CAU 410 soil sampling indicates that cross contamination from field methods did not occur during sample collection. Field, equipment rinsate, and source blanks were analyzed for the parameters specific to each CAS that are given in the tables referenced above. Trip blanks were analyzed for VOCs only. Several different analytes were detected in some of the samples but they were below or slightly above the contract-required detection limit (CRDLs).

During the sampling events, 11 field duplicate soil samples were sent as blind samples to the laboratory to be analyzed for the investigation parameters listed in each CAS-specific table. For these samples, the duplicate results precision (i.e., RPDs between the environmental sample results and their corresponding field duplicate sample results) were evaluated to the guidelines set forth in EPA Functional Guidelines (EPA, 1994a and 2000a).

\section{A.8.2.2 Laboratory Quality Control Samples}

Analysis of method QC blanks were performed on each SDG for inorganics. Analysis for surrogate spikes and preparation blanks (PBs) were performed on each SDG for organics only. Initial and continuing calibration and laboratory control samples (LCS) were performed for each SDG. The results of these analyses were used to qualify associated environmental sample results according to EPA Functional Guidelines (EPA, 1994a and 2000a). Documentation of data qualifications resulting from the application of these guidelines is retained in project files as both hard copy and electronic media.

\section{A.8.3 Field Nonconformances}

One field nonconformance was identified regarding trip blanks not sent to the laboratory with the associated samples. It was determined that the water sample 41003317 did not have an associated trip blank because a temperature blank (41003316) was sent in place of a trip blank and the analysis was cancelled. The samples were analyzed without the required associated trip blank and the VOC results were estimated. The estimated VOC results did not impact sample acceptability. Documentation of the nonconformance is retained in the project files. 


\section{A.8.4 Laboratory Nonconformances}

Laboratory nonconformances are generally due to inconsistencies in analytical instrumentation operation, sample preparation, extractions, and fluctuations in internal standard and calibration results. A total of 13 laboratory nonconformances were identified. One laboratory nonconformance was identified regarding five samples analyzed for GRO outside of the 14-day holding time criteria resulting in the estimation (J) of GRO for samples 410AL009, 410AL010, 410AL011, 410AL012, and 410AL013. The nonconformance was a result of the laboratory receiving samples with only 3 to 4 days of holding time remaining due to adverse weather conditions at the laboratory. The nonconformances have been accounted for in the data qualification process. Documentation of the nonconformances are retained in project files. 


\section{A.9.0 Summary}

Analytes detected in soil samples during the CAI were evaluated against PALs to determine the nature and extent of COCs for CAU 410. Assessment of the data generated from investigation activities indicated the PALs were exceeded in soil samples at three CASs for TPH or DU.

However, based on the nature of supplemental field activities implemented to define the nature and extent of debris and COCs in these three CASs, soil that exceeded PALs was removed and disposed as IDW. Data generated from corrective action investigation activities at CAU 410 indicates the following:

CASs 09-21-001-TA09 and TA-21-003-TANL. Initial investigation sample results indicate there were no COCs above regulatory levels at CASs 09-21-001-TA09 and TA-21-003-TANL. Subsequently there were no supplemental field activities performed at these two CASs.

$\boldsymbol{C A S} \boldsymbol{T A - 1 9 - 0 0 2 - T A B 2 . ~ U p o n ~ c o m p l e t i o n ~ o f ~ t h e ~ s u p p l e m e n t a l ~ f i e l d ~ a c t i v i t i e s ~ t h a t ~ i n c l u d e d ~}$ characterizing vertical and lateral extent of potential contamination and performing waste management, there remains no debris or COCs above regulatory levels in the subsurface and surface soils.

CAS TA-21-002-TAAL. Upon completion of the supplemental field activities that included characterizing vertical and lateral extent of potential contamination and performing waste management, there remains no debris or COCs above regulatory levels in the subsurface and surface soils.

CAS 03-19-001. Upon completion of the supplemental field activities that included characterizing vertical and lateral extent of potential contamination and performing waste management, there remains no debris or COCs above regulatory levels in the subsurface soils. 


\section{A.10.0 References}

Adams, S., Shaw Environmental, Inc. 2003. Deviation of Background Based Preliminary Action Levels (PALs) for Radionuclides in Soil at the Nevada Test Site, 3 September. Las Vegas, NV.

Alderson, S., Shaw Environmental, Inc. 2003. Memo to D. Arnold (SAIC) entitled, "CAU 410 PAL Comparison and Review for Radioanalytical Samples Associated with CAS's TA-19-002-TAB2 and TA-21-002-TAAL," 28 August. Las Vegas, NV.

DOE, see U.S. Department of Energy.

DOE/NV, see U.S. Department of Energy, Nevada Operations Office.

EG\&G/EM, see EG\&G Energy Measurements.

EPA, see U.S. Environmental Protection Agency.

EG\&G Energy Measurements. 1980. Aerial photograph 3310-029, 9 August. Nellis Air Force Base, NV: Remote Sensing Laboratory Photo Library.

EG\&G Energy Measurements. 1985. Aerial photograph 5114-031, 5 September. Nellis Air Force Base, NV: Remote Sensing Laboratory Photo Library.

FFACO, see Federal Facility Agreement and Consent Order.

Federal Facility Agreement and Consent Order. 1996 (as amended). Agreed to by the State of Nevada, the U.S. Department of Energy, and the U.S. Department of Defense.

IT, see IT Corporation.

IT Corporation. 2002-2003. CAU 410 Field Investigation Data. Las Vegas, NV.

IT Corporation. 2002a. ITLV Site-Specific Health and Safety Plan, CAU 410, Waste Disposal Site, Tonopah Test Range, Nevada, Rev. 0. Las Vegas, NV.

IT Corporation. 2002b. Radiological Soil Survey of Corrective Action Unit 410. Las Vegas, NV.

McArthur, R.D., and F.L. Miller, Jr. 1989. Off-Site Radiation Exposure Review Project, Phase II Soil Program, DOE/NV/10384--23, Publication No. 45064. Las Vegas, NV: Desert Research Institute. 
Moore, J., Science Applications International Corporation. 1999. Memorandum to M. Todd (SAIC) entitled, "Background Concentrations for NTS and TTR Soil Samples," 3 February. Las Vegas, NV: IT Corporation.

NAC, see Nevada Administrative Code.

NBMG, see Nevada Bureau of Mines and Geology.

NNSA/NV, see U.S. Department of Energy, National Nuclear Security Administration Nevada Operations Office.

Nevada Administrative Code. 2002. NAC 445A.2272, "Contamination of Soil: Establishment of Action Levels." Carson City, NV.

Nevada Bureau of Mines and Geology. 1998. Mineral and Energy Resource Assessment of the Nellis Air Force Range, Open-File Report 98-1. Prepared by J.V. Tingley, S.B. Castor, S.I. Weiss, L.J. Garside, J.G. Price, D.D. LaPointe, H.F. Bonham, and T.P. Lugaski. Reno, NV.

Paar, J.G., and D.R. Porterfield. 1997. Evaluation of Radiochemical Data Usability, April, $\mathrm{ES} / \mathrm{ER} / \mathrm{MS}-5$.

RSN, see Raytheon Services Nevada.

Raytheon Services Nevada. Date Unknown. Engineering drawing POC-4 entitled, "TTR Environmental Point of Contact." Las Vegas, NV.

Shaw, see Shaw Environmental and Infrastructure, Inc.

SNL, see Sandia National Laboratories.

Sandia National Laboratories. 1999. 1998 Annual Site Environmental Report, Tonopah Test Range, Nevada, SAND99-2279. Albuquerque, NM.

Shaw Environmental and Infrastructure, Inc. 2002. Results of Geophysical Survey Corrective Action Unit 410 Tonopah Test Range Tonopah, Nevada. Sacramento, CA.

U.S. Department of Energy, National Nuclear Security Administration Nevada Operations Office. 2002a. Corrective Action Investigation Plan for Corrective Action Unit 410: Waste Disposal Trenches, Tonopah Test Range, Nevada, Rev. 0, DOE/NV--676. Las Vegas, NV.

U.S. Department of Energy, National Nuclear Security Administration Nevada Operations Office. 2002b. Industrial Sites Quality Assurance Project Plan, Nevada Test Site, Nevada, Rev. 3, DOE/NV--372. Las Vegas, NV. 
U.S. Department of Energy, Nevada Operations Office. 1994. Resource Conservation Recovery Act Facility Investigation Work Plan, Draft, Volume 1, May. Las Vegas, NV.

U.S. Department of Energy, Nevada Operations Office. 1996. Corrective Action Unit Work Plan, Tonopah Test Range, Nevada, DOE/NV--443. Las Vegas, NV.

US Ecology and Atlan-Tech. 1991. Environmental Monitoring Report for the Proposed Ward Valley, California, Low-Level Radioactive Waste (LLRW) Facility. Rosewall, GA.

U.S. Environmental Protection Agency. 1994a. Contract Laboratory Program National Functional Guidelines for Inorganic Data Review, EPA 540/R-94/013. Washington, DC.

U.S. Environmental Protection Agency. 1994b. Guidance for the Data Quality Objectives Process, EPA QA/G-4. Washington, DC: Government Printing Office.

U.S. Environmental Protection Agency. 1996. Test Methods for Evaluating Solid Waste, Physical/Chemical Methods, SW-846, Third Edition, CD ROM, PB97-501928GEI (CD ROM contains revisions to 1986, 1992, and 1994). Washington, DC.

U.S. Environmental Protection Agency. 2000a. Contract Laboratory Program National Functional Guidelines for Organic Data Review, EPA 540/R-99/008. Washington, DC.

U.S. Environmental Protection Agency. 2000b. Region 9 Preliminary Remediation Goals (PRGs) 1999, 1 October. Prepared by S.J. Smucker. San Francisco, CA.

USGS, see U.S. Geological Survey.

U.S. Geological Survey. 1971. Geology of Northern Nellis Air Force Base Bombing and Gunnery Range, Nye County, Nevada. Prepared by E.B. Ekren, R.E. Andersen, C.L. Rogers, and D.C. Noble for the U.S. Atomic Energy Commission. Washington, DC: U.S. Government Printing Office.

U.S. Geological Survey. 2001. "Northwest Regional Area Map.” As accessed at http://nevada.usgs.gov/doe_nv/nwmap.shtm on May 13, 2002. 


\section{Appendix B}

\section{Data Assessment for CAU 410}




\section{B.1.0 Data Assessment}

This appendix provides a summary of the assessment of CAU 410 data validation results for each DQI. In addition, a reconciliation of the data with generalized CSMs established for this project is provided.

\section{B.1.1 Statement of Acceptability and Usability}

This section provides an evaluation of the DQIs in determining the degree of acceptability and usability of the reported data in the decision-making process.

Data were evaluated against specific criteria to verify the achievement of DQI goals established to meet the project DQOs as provided in the Industrial Sites QAPP (NNSA/NV, 2002b) and the CAU 410 CAIP (NNSA/NV, 2002a). The DQIs for this project include precision, accuracy, completeness, representativeness, and comparability.

\section{B.1.1.1 Precision}

Precision is a measure of agreement among a replicate set of measurements of the same property under similar conditions. This agreement is expressed as the relative percent difference (RPD) between duplicate measurements (EPA, 1996). The RPD is determined by dividing the difference between the replicate measurement values by the average measurement value and multiplying the result by 100 , or:

$$
\mathrm{RPD}=* 100 \times\left[\left(\left(\mathrm{a}_{1}-\mathrm{a}_{2}\right) /\left(\mathrm{a}_{1}+\mathrm{a}_{2}\right) / 2\right)\right]^{*}
$$

where

$\mathrm{a}_{1} \quad=$ The sample value, and

$\mathrm{a}_{2} \quad=$ The duplicate sample value.

Determinations of precision can be made for field samples, laboratory duplicates, or both. For field samples, duplicates are collected simultaneously with a sample from the same source under similar conditions in separate containers. The duplicate sample is treated independently of the original sample in order to assess field impacts and laboratory performance on precision through a 
comparison of results. Laboratory precision is evaluated as part of the required laboratory internal QC program to assess performance of analytical procedures. The laboratory sample duplicates are an aliquot or subset of a field sample generated in the laboratory. They are not a separate sample but portions of an existing sample. Typically, other laboratory duplicate QC samples include MSD and laboratory control sample duplicate (LCSD) samples.

The variability in the results from the analysis of field duplicates is generally greater than the variability in the results of laboratory duplicates. This higher variability for field duplicates results from the increased potential to introduce factors influencing the analytical results during sampling, sample preparation, containerization, handling, packaging, preservation, and environmental conditions before the samples reach the laboratory. Laboratory QC samples assess only the variability of results introduced by sample handling and preparation in the laboratory and by the analytical procedure, which also impacts field duplicates. In addition, the variability in duplicate results is expected to be greater for soil samples than water samples, primarily due to the inherent nonhomogeneous nature of soil samples, despite sample preparation methods that include mixing to improve sample homogeneity.

\section{B.1.1.1.1 Precision for Chemical Analyses}

The RPD criteria used for assessment of laboratory sample duplicate precision for analytical results of samples collected at CAU 410 were established as follows:

- Inorganic analysis RPD criteria is obtained from the EPA Contract Laboratory Program National Functional Guidelines for Inorganic Data Review (EPA, 1994).

- Organic analysis RPD criteria is established by the laboratory to evaluate precision for MSD and LCSD analyses.

- The control limits are evaluated at the laboratory on a quarterly basis by monitoring the historical data and performance for each method.

- No review criteria for organic field duplicate RPD comparability have been established; therefore, the laboratory MSD RPD criteria is applied for precision evaluation of field duplicates.

Precision values for organic and inorganic analysis that are within the established control criteria indicate that analytical results for associated samples are valid. Laboratory duplicate RPD values that 
are outside the criteria for organic analysis do not necessarily result in the qualification of analytical data. It is only one factor in making an overall judgment about the quality of the reported analytical results. Inorganic laboratory duplicate RPD values outside the established control criteria do result in the qualification of associated analytical results as estimated. Field duplicate RPD values that are outside the criteria for organic and inorganic analyses do not result in the qualification of analytical data. Out of control RPD values do not necessarily indicate that the data are not useful for the purpose intended; however, it is an indication data precision should be considered for the overall assessment of the data quality and potential impact on data application in meeting project site characterization objectives. Method-specific precision as RPD is determined by taking the number of measurements within criteria, dividing that by the number of measurements analyzed, and multiplying by 100 .

For the purpose of determining data precision of sample analyses for CAU 410, all water and soil samples, including field QC samples (i.e., trip blanks, equipment rinsate samples, field blanks) were evaluated and incorporated into the precision calculation.

Precision for the measurement of target compounds or analytes collected at CAU 410 was determined for RCRA metals and beryllium, VOCs, SVOCs, TPH-DRO and TPH-GRO, explosives, pesticides, PCBs, and herbicides.

Table B.1-1 provides the field and laboratory duplicate precision analysis results.

Inorganic laboratory duplicate RPD values outside the established control criteria result in estimation for that measurement of all associated samples in the SDG. For example, if a laboratory duplicate had an RPD value for lead outside the established control criteria, lead results for all of the samples in that SDG would be qualified as estimated.

Out of control RPD values do not necessarily indicate that the data is not useful for the purpose intended. It does indicate that precision should be considered for the overall assessment of the data quality and impact to the application of associated data to meeting project's objectives. 
Table B.1-1

Chemical Precision Measurements for CAU 410

(Page 1 of 2)

\begin{tabular}{|c|c|c|c|c|c|c|c|c|c|c|}
\hline & \multicolumn{8}{|c|}{ ORGANICS } & \multicolumn{2}{|c|}{ INORGANICS } \\
\hline & VOCs & SVOCs & $\begin{array}{l}\text { TPH- } \\
\text { DRO }\end{array}$ & $\begin{array}{l}\text { TPH- } \\
\text { GRO }\end{array}$ & Explosive & Pesticides & PCBs & Herbicides & Metals & Mercury \\
\hline \multicolumn{11}{|c|}{ Matrix Spike Duplicate (MSD) Precision } \\
\hline $\begin{array}{l}\text { Total Number of MSD } \\
\text { Measurements }\end{array}$ & 45 & 99 & 11 & 9 & 98 & 18 & 6 & 9 & 16 & 4 \\
\hline $\begin{array}{l}\text { Total Number of RPDs } \\
\text { within Criteria }\end{array}$ & 45 & 99 & 10 & 9 & 98 & 18 & 5 & 9 & 16 & 4 \\
\hline MSD \% Precision & 100 & 100 & 90.91 & 100 & 100 & 100 & 83.33 & 100 & 100 & 100 \\
\hline \multicolumn{11}{|c|}{ Laboratory Control Sample Duplicate (LCSD) Precision } \\
\hline $\begin{array}{l}\text { Total Number of LCSD } \\
\text { Measurements }\end{array}$ & 130 & 165 & 17 & 17 & 182 & 42 & 14 & 21 & 134 & 18 \\
\hline $\begin{array}{l}\text { Total Number of RPDs } \\
\text { within Criteria }\end{array}$ & 130 & 165 & 17 & 17 & 182 & 42 & 14 & 21 & 134 & 18 \\
\hline LCSD \% Precision & 100 & 100 & 100 & 100 & 100 & 100 & 100 & 100 & 100 & 100 \\
\hline \multicolumn{11}{|c|}{ Field Sample Duplicate (FD) Precision } \\
\hline $\begin{array}{l}\text { Total Number of FD } \\
\text { Measurements }\end{array}$ & 492 & 134 & 7 & 6 & 84 & 21 & 7 & 10 & 60 & 6 \\
\hline $\begin{array}{l}\text { Total Number of RPDs } \\
\text { within Criteria }\end{array}$ & 491 & 134 & 6 & 6 & 84 & 21 & 7 & 10 & 55 & 5 \\
\hline FD \% Precision & 99.80 & 100 & 85.71 & 100 & 100 & 100 & 100 & 100 & 91.67 & 83.33 \\
\hline \multicolumn{11}{|c|}{ Laboratory Sample Duplicate (Lab-Dup) Precision } \\
\hline $\begin{array}{l}\text { Total Number of } \\
\text { Lab-Dup Measurements }\end{array}$ & NA & NA & NA & NA & NA & NA & NA & NA & 78 & 10 \\
\hline
\end{tabular}


Table B.1-1

Chemical Precision Measurements for CAU 410

(Page 2 of 2)

\begin{tabular}{|c|c|c|c|c|c|c|c|c|c|c|}
\hline & \multicolumn{8}{|c|}{ ORGANICS } & \multicolumn{2}{|c|}{ INORGANICS } \\
\hline & VOCs & SVOCs & $\begin{array}{l}\text { TPH- } \\
\text { DRO }\end{array}$ & $\begin{array}{l}\text { TPH- } \\
\text { GRO }\end{array}$ & Explosive & Pesticides & PCBs & Herbicides & Metals & Mercury \\
\hline \multicolumn{11}{|c|}{ Laboratory Sample Duplicate (Lab-Dup) Precision } \\
\hline $\begin{array}{l}\text { Total Number of RPDs } \\
\text { within Criteria }\end{array}$ & NA & NA & NA & NA & NA & NA & NA & NA & 78 & 10 \\
\hline Lab-Dup \% Precision & NA & NA & NA & NA & NA & NA & NA & NA & 100 & 100 \\
\hline
\end{tabular}

Arsenic, Barium, Beryllium, Cadmium, Chromium, Lead, Selenium, Silver 


\section{B.1.1.1.2 Precision for Radiological Analysis}

The precision of radiochemical measurements is evaluated by measuring two aliquots of a sample and comparing the results. A laboratory duplicate is measured with every batch of samples analyzed by the laboratory. Field duplicate data is available when two aliquots of a sample are submitted to the laboratory for analysis. Laboratory control sample duplicates are measured by the laboratory when there is insufficient sample to measure a duplicate of a field sample. Matrix spike duplicates, also used to evaluate precision, are performed by the laboratory upon request.

The duplicate precision is evaluated using the RPD or normalized difference. The RPD is applicable when both the sample and its duplicate have concentrations of the target radionuclide exceeding five times their minimum detectable concentration. This excludes many measurements because the samples contain nondetectable or low levels of the target radionuclide. In situations where the RPD does not apply, duplicate results are evaluated using the normalized difference which is expressed by:

$$
\text { Normalized Difference }=\frac{\mathrm{S}-\mathrm{D}}{\sqrt{\left(\mathrm{TPU}_{\mathrm{S}}\right)^{2}+\left(\mathrm{TPU}_{\mathrm{D}}\right)^{2}}}
$$

Where:

$$
\begin{array}{ll}
\mathrm{S} & =\text { Sample result } \\
\mathrm{D} & =\text { Duplicate Result } \\
\mathrm{TPU}_{\mathrm{S}} & =2 \sigma \mathrm{TPU} \text { of the sample } \\
\mathrm{TPU}_{\mathrm{D}} & =2 \sigma \mathrm{TPU} \text { of the duplicate } \\
\sigma & =\text { Standard deviation }
\end{array}
$$

The control limit for the normalized difference is -1.96 to 1.96 , which represent a confidence level of 95 percent. Depending on the sample concentration, only one duplicate evaluation needs to be performed.

Samples are qualified based on laboratory prepared duplicates, but not field duplicates or MSDs.

A duplicate comparison that is outside control limits does not necessarily indicate that the data is not useful for the purpose intended; however, it is an indication that data precision should be considered for the overall assessment of the data quality and potential impact on data application in meeting project site characterization objectives. 
For the purpose of determining data precision of sample analyses for CAU 410, all water and soil duplicates were evaluated and incorporated into Table B.1-2 and Table B.1-3.

Table B.1-2

Laboratory Duplicate Precision for Radioanalytes

\begin{tabular}{||l|c|c|c||}
\hline & Gamma Spectroscopy & Isotopic Uranium & Isotopic Plutonium \\
\hline \hline \multicolumn{2}{|c|}{ Relative Percent Different } \\
\hline \hline Number Performed & 41 & 50 & 2 \\
\hline Number Within Limits & 41 & 48 & 2 \\
\hline Percent Within Limits & 100 & 96 & 100 \\
\hline \hline \multicolumn{2}{|c|}{ Normalized Difference } & 32 \\
\hline \hline Number Performed & 404 & 25 & 32 \\
\hline Number Within Limits & 401 & 100 & 100 \\
\hline Percent Within Limits & 99 & 25 & \\
\hline
\end{tabular}

Table B.1-3

Laboratory Matrix Spike/Matrix Spike Duplicate Precision for Radioanalytes

\begin{tabular}{||l|c|c|}
\hline & Isotopic Uranium & Isotopic Plutonium \\
\hline \hline \multicolumn{2}{|c|}{ Relative Percent Different } \\
\hline \hline Number Performed & 2 & 1 \\
\hline Number Within Limits & 2 & 1 \\
\hline Percent Within Limits & 100 & 100 \\
\hline
\end{tabular}

The isotopic gamma analysis provides results for 22-24 radionuclides. Only two or three of these radionuclides are usually present in sufficient concentrations to allow the determination of their RPDs. The duplicate data for the remaining radionuclides is compared using the normalized difference. The isotopic uranium analysis provides results for three uranium isotopes while the isotopic plutonium $(\mathrm{Pu})$ analysis gives results for $\mathrm{Pu}-238$ and $\mathrm{Pu}-239 / 240$. 
The comparisons of field duplicates are included in Table B.1-4. All of the field duplicate comparisons were within the control limits except for one uranium RPD. No field samples were qualified based on the RPD being outside control limits.

Table B.1-4

Field Duplicate Precision for Radioanalytes

\begin{tabular}{||c|c|c|c||}
\hline & Gamma Spectroscopy & Isotopic Uranium & Isotopic Plutonium \\
\hline \hline \multicolumn{5}{|c|}{ Relative Percent Difference } \\
\hline \hline Number Performed & 17 & 19 & 0 \\
\hline Number Within Limits & 17 & 18 & NA \\
\hline Percent Within Limits & 100 & 95 & 8 \\
\hline \hline \multicolumn{5}{|c|}{ Normalized Difference } & 8 \\
\hline \hline Number Performed & 166 & 8 & 100 \\
\hline Number Within Limits & 166 & 8 & 100 \\
\hline Percent Within Limits & 100 & & \\
\hline
\end{tabular}

NA $=$ Not applicable

\section{B.1.1.1.3 Precision Summary}

Overall, the precision for CAU 410 measurements were within the DQI specifications. Accounting for sample heterogeneity, the precision of the dataset for chemical analyses is demonstrated to be very high. Laboratory measurement error associated with analytical measurement variability is well within acceptable limits. Laboratory and field precision tests were performed for gamma spectroscopy, isotopic uranium, and isotopic plutonium. All the measurements were within the control limits except one uranium RPD and three gamma duplicates compared using the normalized difference.

\section{B.1.1.2 Accuracy}

Accuracy is a measure of the closeness of an individual measurement or the average of a number of measurements to the true value. Accuracy includes a combination of random error (precision) and systematic error (bias) components that result from sampling and analytical operations. 


\section{B.1.1.2.1 Accuracy for Chemical Analyses}

Accuracy is determined by analyzing a reference material of known pollutant concentration or by reanalyzing a sample to which a material of known concentration or amount of pollutant has been added (spiked). Accuracy is expressed as $\% \mathrm{R}$ for the purposes of evaluating the quality of data reported for CAU 410.

Matrix spike samples are prepared by adding a known concentration of a target analyte to a specified amount of matrix sample for which an independent estimate of the target analyte concentration is available. Spiked samples are used to determine the laboratory's overall efficiency by comparing the percent recovered to the known true value. For example, a sample that is spiked with $10 \mathrm{ppm}$ of a known analyte should produce a reported result of $10 \mathrm{ppm}$ greater than the value of the sample itself. Consequently, the accuracy for this analysis would be reported as 100 percent. Matrix spike recoveries within the specified criteria for organic and inorganic analyses indicate the laboratory is operating within established controls and producing valid, quality results. Matrix spike results outside the control limits for organic analyses may not result in qualification of the data. An assessment of the entire analytical process is performed to determine the quality of the data and whether qualification is necessary.

Laboratory control samples are generated to provide accuracy of analytical methods and laboratory performance. They are prepared, extracted (as required by method), analyzed, and reported once per SDG, per matrix. For organic analyses, laboratory control limits are used to evaluate the accuracy of all analyses. The control limits are evaluated at the laboratory quarterly by monitoring the historical data and performance for each method. The acceptable limits for inorganic analyses are established in the EPA Contract Laboratory Program National Functional Guidelines for Inorganic Data Review (EPA, 1994). Sample results within established control ranges for organic and inorganic analyses show that the analytical method is accurate and the data provided are valid.

Surrogates (System Monitoring Compounds) are used to assess the method performance for each sample analyzed for organic analyses. Control limits established by the laboratory are used to evaluate the accuracy of the surrogate recoveries. Factors beyond the laboratory's control, such as sample matrix effects, can cause the measured values to be outside of the established criteria. 
Therefore, the entire sampling and analytical process must be evaluated when determining the quality of the analytical data provided.

Table B.1-5 identifies the number of matrix spike, laboratory control, and surrogate measurements performed for CAU 410. The table presents the total number of measurements analyzed, the number of measurements within the specified criteria, and the percent-accuracy of each method. Methodspecific accuracy is determined by taking the number of measurements within criteria, dividing that by the total number of measurements analyzed, and multiplying by 100 . For organic analyses, each sample had surrogates analyzed; therefore, the number of surrogates is significantly greater than the number of matrix spike and laboratory control samples.

The MS accuracy results for organic analyses in Table B.1-5 include the total number of MS measurements per analysis and the number of MS measurements within criteria. All samples for organic analyses within the associated SDG are not qualified, only the native sample in which the spike was added. Inorganic MS results outside of the established control criteria do result in data qualified as estimated for all the samples in that batch. However, only the analyte(s) outside of control requires qualification.

Table B.1-5 includes the total number of LCS measurements per analysis and the number of LCS measurements within criteria. Laboratory control samples within the specified criteria for organic and inorganic analyses indicate the laboratory is producing valid data. Laboratory control samples outside of the established criteria result in the qualification of inorganic data and may result in the qualification of organic data. For organic analyses, an evaluation of the overall analytical process is performed to determine if data qualification is necessary. Inorganic LCS recoveries outside of established controls require data to be qualified for the individual analyte out of control. If the LCS criteria are not met, the laboratory performance and method accuracy are in question.

Surrogates reported within established control criteria indicate good laboratory method performance and the absence of matrix influences on the samples and result in quality, valid data. Table B.1-5 includes the total number of sample measurements performed for each method and the total number of sample measurements qualified for surrogate recoveries exceeding criteria. The estimated organic data in this CAU do not necessarily indicate the data is not useful. Data qualification is one factor to be considered in the overall assessment of the data quality and the impact to the project's objectives. 
Table B.1-5

Laboratory Accuracy Measurements for CAU 410

\begin{tabular}{|c|c|c|c|c|c|c|c|c|c|c|}
\hline & \multicolumn{8}{|c|}{ ORGANICS } & \multicolumn{2}{|c|}{ INORGANICS } \\
\hline & VOCs & SVOCs & $\begin{array}{l}\text { TPH- } \\
\text { DRO }\end{array}$ & $\begin{array}{l}\text { TPH- } \\
\text { GRO }\end{array}$ & EXPLOSIVES & PESTICIDES & PCBS & HERBICIDES & METALS & MERCURY \\
\hline \multicolumn{11}{|c|}{ Matrix Spike (MS) Accuracy } \\
\hline $\begin{array}{l}\text { Total Number of MS } \\
\text { Measurements }\end{array}$ & 90 & 198 & 22 & 18 & 210 & 36 & 12 & 18 & 86 & 14 \\
\hline $\begin{array}{l}\text { Total Number of MS } \\
\text { Measurements Within Criteria }\end{array}$ & 90 & 198 & 21 & 15 & 209 & 31 & 11 & 17 & 86 & 14 \\
\hline MS \% Accuracy & 100 & 100 & 95.45 & 83.33 & 99.52 & 86.11 & 91.67 & 94.44 & 100 & 100 \\
\hline \multicolumn{11}{|c|}{ Laboratory Control Sample (LCS) Accuracy } \\
\hline $\begin{array}{l}\text { Total Number of LCS } \\
\text { Measurements }\end{array}$ & 260 & 352 & 36 & 34 & 364 & 84 & 28 & 42 & 268 & 36 \\
\hline $\begin{array}{l}\text { Total Number of LCS } \\
\text { Measurements Within Criteria }\end{array}$ & 260 & 351 & 36 & 34 & 364 & 84 & 28 & 42 & 268 & 36 \\
\hline LCS \% Accuracy & 100 & 99.72 & 100 & 100 & 100 & 100 & 100 & 100 & 100 & 100 \\
\hline \multicolumn{11}{|c|}{ Surrogate Accuracy } \\
\hline $\begin{array}{l}\text { Total Number of Measurements } \\
\text { Analyzed }\end{array}$ & 8553 & 6945 & 108 & 88 & 1092 & 630 & 223 & 300 & NA & NA \\
\hline $\begin{array}{l}\text { Total Number of Measurements } \\
\text { not Affected by Out-of-Control } \\
\text { Surrogates }\end{array}$ & 8551 & 6939 & 107 & 88 & 1092 & 558 & 196 & 300 & NA & NA \\
\hline Surrogate \% Accuracy & 99.98 & 99.91 & 99.07 & 100 & 100 & 88.57 & 87.89 & 100 & NA & NA \\
\hline
\end{tabular}

Arsenic, Barium, Beryllium, Cadmium, Chromium, Lead, Selenium, Nickel 
Accuracy for the measurement of target analytes collected at CAU 410 was determined for RCRA metals and beryllium, VOCs, SVOCs, TPH-DRO and TPH-GRO, explosives, pesticides, PCBs, and herbicides.

For the purpose of determining data accuracy of sample analysis for CAU 410, all water and soil samples including field QC samples (i.e., trip blanks, equipment rinsate samples, field blanks) were evaluated and incorporated into the accuracy calculation.

\section{B.1.1.2.2 Accuracy for Radiological Analyses}

Laboratory control samples and MS samples are used to determine the accuracy of radioanalytical measurements. The LCS is prepared by adding a known concentration of the radionuclide being measured to a sample that doesn't contain radioactivity (i.e., distilled water). This sample is analyzed with the field samples using the same sample preparation, reagents, and analytical methods employed for the samples. One LCS is prepared with each batch of samples for analysis by a specific measurement. The MS samples are prepared by adding a known concentration of the target radionuclide to a specified field sample with a measured concentration.

The accuracy of the LCS determination is expressed as a percent recovery by the following:

$$
\% \text { Recovery }(\% \mathrm{R})=\frac{\text { Amount of Analyte Measured }}{\text { Amount of Analyte Added }} \times 100
$$

If the LCS results are outside acceptable control limits, qualifiers will be added to the field samples analyzed with the LCS.

Table B.1-6 and Table B.1-7 gives the number of laboratory control samples and matrix spike samples, including soil and water matrices, measured for each radiochemical measurement for CAU 410. The percent accuracy for the procedure is determined as the number of LCS or MS measurements that are within the control limits divided by the total number of analyses, multiplied by 100 . 
Table B.1-6

Radioanalytical Laboratory Control Sample (LCS) Accuracy

\begin{tabular}{|l|c|c|c|}
\hline & $\begin{array}{c}\text { Gamma } \\
\text { Spectroscopy }\end{array}$ & Isotopic Uranium & Isotopic Plutonium \\
\hline \hline Total Number & 59 & 48 & 17 \\
\hline Total Number within Criteria & 59 & 48 & 17 \\
\hline LCS \% Accuracy & 100 & 100 & 100 \\
\hline
\end{tabular}

Table B.1-7

Radioanalytical Matrix Spike (MS) Accuracy

\begin{tabular}{|l|c|c|c|}
\hline & $\begin{array}{c}\text { Gamma } \\
\text { Spectroscopy }\end{array}$ & Isotopic Uranium & Isotopic Plutonium \\
\hline \hline Total Number & NA & 4 & 2 \\
\hline Total Number within Criteria & NA & 4 & 2 \\
\hline MS \% Accuracy & NA & 100 & 100 \\
\hline
\end{tabular}

NA = Not applicable

Laboratory control samples within the specified criteria for radiological analyses indicate the laboratory is producing valid data. If the LCS criteria are not met, the laboratory performance and method accuracy are in question. Radiological LCS recoveries outside of established controls require data to be qualified for the individual radionuclide that is out of control. Since LCS recoveries were 100 percent for all analyses, no field samples were qualified based on LCS performance.

None of the MS recoveries were outside of control limits.

\section{B.1.1.2.3 Accuracy Summary}

Overall, the accuracy for CAU 410 was within acceptable limits. Of the 17,939 chemical surrogate measurements, 17,831 or 99 percent were not affected by out of control surrogates. Of the 2,208 chemical MS and LCS measurements, 2,195 or 99 percent were within criteria. All of the 
radioanalyte LCSs were within criteria. Therefore, the measurements for CAU 410 are considered valid in regard to accuracy.

\section{B.1.1.3 Completeness}

Completeness is defined as the acquisition of sufficient data of the appropriate quality to satisfy DQO decision data requirements. A measure of completeness is the amount of data that are judged to be valid. Percent completeness for sample analyses was determined by dividing the total number of samples analyzed (per method) by the total number of samples sent to the lab and multiplied by 100 . Percent completeness for measurement usability (not rejected) was determined by dividing the total number of unrejected measurements by the total number measurements (per method) and multiplied by 100. All measurements for completeness include reanalyses. Table B.1-8 and Table B.1-9 contain results of completeness per analytical method.

The specified sampling locations were used as planned and all samples were collected as specified in the CAU 410 CAIP (NNSA/NV, 2002a). Trip blank sample TB41003316 VOC analysis was cancelled because the label read "EMAX TEMP BLANK."

In accordance with the CAU 410 CAIP (Table 6-1), 80 percent of CAS-specific noncritical samples and analyses had valid results. All of CAS-specific critical parameters had valid results with the exception of CAS TA-21-002-TAAL, which had U-234, U-235, and U-238 results rejected for samples 410AL520 and 410AL521. However, the laboratory reanalyzed both of these samples and the results were acceptable for the purpose of waste determination.

The analytical results for two VOC analyses were rejected because sample temperature was not documented during storage. The analytical results for three SVOC analyses were rejected due to possible matrix effects or because internal standard area count exceeded the QC limits. These rejected data do not affect closure decisions because data from other depths can be used.

The CAU 410 dataset provides sufficient information to support the decisions and meets the data quality objectives for completeness stipulated in the CAIP. 
Table B.1-8

Page B-15 of B-21

Chemical Completeness for CAU 410

\begin{tabular}{|c|c|c|c|c|c|c|c|c|c|c|}
\hline \multirow[b]{2}{*}{ Completeness Parameters } & \multicolumn{8}{|c|}{ ORGANICS } & \multicolumn{2}{|c|}{ INORGANICS } \\
\hline & VOCs & SVOCs & $\begin{array}{l}\text { TPH- } \\
\text { DRO }\end{array}$ & $\begin{array}{l}\text { TPH- } \\
\text { GRO }\end{array}$ & EXPLOSIVES & PESTICIDES & PCBs & HERBICIDES & METALS & MERCURY \\
\hline \multicolumn{11}{|c|}{ Sample Analysis Completeness } \\
\hline Total samples sent to Lab & 126 & 97 & 108 & 88 & 78 & 30 & 33 & 30 & 108 & 95 \\
\hline Total samples analyzed & 125 & 97 & 108 & 88 & 78 & 30 & 33 & 30 & 108 & 95 \\
\hline $\begin{array}{l}\text { Total samples not analyzed by } \\
\text { the lab }\end{array}$ & 1 & 0 & 0 & 0 & 0 & 0 & 0 & 0 & 0 & 0 \\
\hline -Analyses cancelled per Shaw & 1 & & & & & & & & & \\
\hline Percent Completeness & 99.21 & 100 & 100 & 100 & 100 & 100 & 100 & 100 & 100 & 100 \\
\hline \multicolumn{11}{|c|}{ Measurement Usability Completeness } \\
\hline Total measurements ** & 8553 & 6945 & 108 & 88 & 1092 & 630 & 244 & 300 & 750 & 95 \\
\hline $\begin{array}{l}\text { Total measurements rejected - } \\
\text { Field }\end{array}$ & 0 & 0 & 0 & 0 & 0 & 0 & 0 & 0 & 0 & 0 \\
\hline $\begin{array}{l}\text { Total measurements rejected - } \\
\text { Lab/Matrix }\end{array}$ & 28 & 29 & 0 & 0 & 0 & 0 & 0 & 0 & 0 & 0 \\
\hline Percent Completeness & 99.67 & 99.58 & 100 & 100 & 100 & 100 & 100 & 100 & 100 & 100 \\
\hline
\end{tabular}

Arsenic, Barium, Beryllium, Cadmium, Chromium, Lead, Selenium, Silver

${ }^{* *}$ Measurements include reanalyses 
Table B.1-9

Radiological Completeness for CAU 410

\begin{tabular}{||l|c|c|c||}
\hline \multicolumn{1}{|c|}{ Completeness Parameters } & $\begin{array}{c}\text { Gamma } \\
\text { Spectrometry }\end{array}$ & $\begin{array}{c}\text { Isotopic } \\
\text { Uranium }\end{array}$ & $\begin{array}{c}\text { Isotopic } \\
\text { Plutonium }\end{array}$ \\
\hline \hline \multicolumn{4}{|c||}{ Sample Analysis Completeness } \\
\hline \hline Total samples sent to Lab & 99 & 122 & 71 \\
\hline Total samples analyzed & 99 & 122 & 71 \\
\hline Percent Completeness & 100 & 100 & 100 \\
\hline \hline \multicolumn{3}{|c|}{ Measurement Usability Completeness } \\
\hline \hline Total measurements ** & 2,210 & 372 & 142 \\
\hline Total measurements rejected - Field & 0 & 0 & 0 \\
\hline Total measurements rejected - Lab/Matrix & 16 & 6 & 0 \\
\hline Percent Completeness & 99.28 & 98.39 & 100 \\
\hline
\end{tabular}

**Measurements include reanalyses

\section{B.1.1.3.1 Rejected Data}

Data identified as unusable and qualified as rejected " $\mathrm{R}$ " during Tier II data validation is presented in Table B.1-10.

\section{B.1.1.4 Representativeness}

A seven-step DQO process was utilized to identify CAU 410 requirements. During the process, locations were selected that enabled the samples collected to be representative of the media being evaluated. Samples were collected as planned. Quality control blanks are used as a way of measuring outside factors that could impact sample results. No data was rejected due to QC blanks. Therefore, the analytical data acquired during the CAU 410 investigation are representative of site characteristics and the dataset satisfies the data quality objectives for representativeness stipulated in the CAIP.

\section{B.1.1.5 Comparability}

Field sampling activities were performed and documented in accordance with approved procedures that are comparable to standard industry practices. Approved standardized methods and procedures 
Table B.1-10

CAU 410 Rejected Data

(Page 1 of 2)

\begin{tabular}{|c|c|c|c|}
\hline Sample Number & Laboratory Method & Parameter & $\begin{array}{c}\text { Sample } \\
\text { Matrix }\end{array}$ \\
\hline \multicolumn{4}{|c|}{ TA-21-003-TANL } \\
\hline 410NL003 & HASL300 & Radium-226 & Soil \\
\hline 410NL003 & HASL300 & Thorium-227 & Soil \\
\hline \multicolumn{4}{|c|}{ CAS 09-21-001-TA09 } \\
\hline 41009001 & EPA8260 & 1,2-Dibromo-3-Chloropropane & Soil \\
\hline 41009001 & EPA8260 & Bromomethane & Soil \\
\hline 41009001 & HASL300 & Radium-226 & Soil \\
\hline 41009001 & HASL300 & Thorium-227 & Soil \\
\hline 41009002 & EPA8260 & 1,2-Dibromo-3-Chloropropane & Soil \\
\hline 41009002 & EPA8260 & Bromomethane & Soil \\
\hline 41009003 & EPA8260 & 1,2-Dibromo-3-Chloropropane & Soil \\
\hline 41009003 & EPA8260 & Bromomethane & Soil \\
\hline 41009003 & HASL300 & Radium-226 & Soil \\
\hline 41009003 & HASL300 & Thorium-227 & Soil \\
\hline
\end{tabular}

CAS TA-19-002-TAB2

\begin{tabular}{|l|l|l|c|}
\hline \hline 410B2001 & HASL300 & Radium-226 & Soil \\
\hline $410 B 2003$ & HASL300 & Radium-226 & Soil \\
\hline $410 B 2003$ & HASL300 & Thorium-227 & Soil \\
\hline $410 B 2004$ & HASL300 & Radium-226 & Soil \\
\hline \hline
\end{tabular}

CAS TA-21-001-TAAL

\begin{tabular}{||c|c|c|c||}
\hline \hline 410AL001 & EPA8260 & 1,2-Dibromo-3-Chloropropane & Soil \\
\hline $410 A L 001$ & EPA8260 & Bromomethane & Soil \\
\hline $410 A L 001$ & HASL300 & Radium-226 & Soil \\
\hline $410 A L 001$ & HASL300 & Thorium-227 & Soil \\
\hline $410 A L 002$ & EPA8260 & 1,2-Dibromo-3-Chloropropane & Soil \\
\hline $410 A L 002$ & EPA8260 & Bromomethane & Soil \\
\hline $410 A L 003$ & EPA8260 & 1,2-Dibromo-3-Chloropropane & Soil \\
\hline $410 A L 003$ & EPA8260 & Bromomethane & Soil \\
\hline $410 A L 003$ & HASL300 & Radium-226 & Soil \\
\hline $410 A L 515$ & HASL300 & Thorium-234 & Soil \\
\hline $410 A L 520$ & ISOU & Uranium-234 & Soil \\
\hline $410 A L 520$ & ISOU & Uranium-235 & \\
\hline
\end{tabular}


Table B.1-10

CAU 410 Rejected Data

(Page 2 of 2)

\begin{tabular}{|c|c|c|c|}
\hline Sample Number & Laboratory Method & Parameter & $\begin{array}{c}\text { Sample } \\
\text { Matrix }\end{array}$ \\
\hline \multicolumn{4}{|c|}{ CAS TA-21-001-TAAL } \\
\hline 410AL520 & $\overline{\text { ISOU }}$ & Uranium-238 & Soil \\
\hline 410AL521 & HASL300 & Americium-241 & Soil \\
\hline 410AL521 & ISOU & Uranium-234 & Soil \\
\hline 410AL521 & ISOU & Uranium-235 & Soil \\
\hline 410AL521 & ISOU & Uranium-238 & Soil \\
\hline \multicolumn{4}{|c|}{ CAS 03-19-001 } \\
\hline$\overline{41003009}$ & EPA8270 & $\overline{\text { Benzo(A)Pyrene }}$ & Soil \\
\hline 41003009 & EPA8270 & Benzo(B)Fluoranthene & Soil \\
\hline 41003009 & EPA8270 & Benzo(G,H,I)Perylene & Soil \\
\hline 41003009 & EPA8270 & Benzo(K)Fluoranthene & Soil \\
\hline 41003009 & EPA8270 & Dibenzo $(\mathrm{A}, \mathrm{H})$ Anthracene & Soil \\
\hline 41003009 & EPA8270 & Indeno(1,2,3-CD)Pyrene & Soil \\
\hline 41003009 & HASL300 & Aluminum-26 & Soil \\
\hline 41003317 & EPA8270 & 3,3'-Dichlorobenzidine & Liquid \\
\hline 41003317 & EPA8270 & Benzo(A)Anthracene & Liquid \\
\hline 41003317 & EPA8270 & Benzo(A)Pyrene & Liquid \\
\hline 41003317 & EPA8270 & Benzo(B)Fluoranthene & Liquid \\
\hline 41003317 & EPA8270 & Benzo(G,H,I)Perylene & Liquid \\
\hline 41003317 & EPA8270 & Benzo(K)Fluoranthene & Liquid \\
\hline 41003317 & EPA8270 & Butyl Benzyl Phthalate & Liquid \\
\hline 41003317 & EPA8270 & Chrysene & Liquid \\
\hline 41003317 & EPA8270 & Dibenzo $(A, H)$ Anthracene & Liquid \\
\hline 41003317 & EPA8270 & Indeno(1,2,3-CD)Pyrene & Liquid \\
\hline 41003317 & EPA8270 & Pyrene & Liquid \\
\hline 41003317RR1 & EPA8270 & Benzo(A)Pyrene & Liquid \\
\hline 41003317RR1 & EPA8270 & Benzo(B)Fluoranthene & Liquid \\
\hline 41003317RR1 & EPA8270 & Benzo(G,H,I)Perylene & Liquid \\
\hline 41003317RR1 & EPA8270 & Benzo(K)Fluoranthene & Liquid \\
\hline 41003317RR1 & EPA8270 & Dibenzo $(A, H)$ Anthracene & Liquid \\
\hline 41003317RR1 & EPA8270 & Indeno(1,2,3-CD)Pyrene & Liquid \\
\hline
\end{tabular}


were also used to analyze, report, and validate the data. Therefore, datasets within this project are comparable to all other datasets generated using standardized quality procedures.

\section{B.1.2 Reconciliation of DQOs to Conceptual Site Model}

This section provides a reconciliation of the data collected and analyzed during this investigation with the preliminary conceptual site models established in the DQO process.

\section{B.1.2.1 Initial Conceptual Site Models}

A single CSM was developed for CAU 410 as presented in the CAIP (NNSA/NV, 2002) based on historical information, geophysical and radiological surveys from July 2002, and process information. This data assessment reconciles the investigation results with the CSM.

The single CSM developed for CAU 410 depicts scenarios where there is a presence of buried debris in the disposal features. The model assumed that if any contaminant was present, it would be located in the subsurface and the extent would be confined laterally within the historic boundaries of the disposal feature, and the potential for vertical migration would be minimal based on geological and historical information for the sites.

\section{B.1.2.2 Investigation Design and Contaminant Identification}

The CSMs were used as the basis for developing the investigation design, which includes identifying appropriate sampling strategies and data collection methods.

To address the CSM, surface and subsurface samples were collected for analyses designed to define the extent of the anomalies identified in the CAIP. A biased strategy was developed to focus the investigation on areas of potential contamination. The CSMs assumed that the contamination would be limited to the boundaries of the site due to the minimal potential for migration based on the geological and historical information for the site.

Implementation of the investigation design has shown that contamination did not extend beyond the disposal feature; therefore, it did not extend beyond the boundaries of the CAS. This is reasonable 
because the model predicts that the extent of impact of any contaminated effluent released to soil is limited (NNSA/NV, 2002a).

\section{B.1.2.3 Contaminant Nature and Extent}

The model assumed that the contamination would be limited to the boundaries of the site due to the minimal potential for migration based on the geological and historical information for the site. The investigation was performed according to design concepts and has shown the extent of the contamination did not exceed the boundaries of the CAS.

\section{B.1.3 Conclusions}

The DQIs (e.g., precision, accuracy, completeness, representativeness, and comparability) were all evaluated for quality and impact to the data. All of the data, except data qualified as rejected, can be used in project decisions. 


\section{B.2.0 References}

U.S. Department of Energy, National Nuclear Security Administration Nevada Operations Office. 2002a. Corrective Action Investigation Plan for Corrective Action Unit 410: Waste Disposal Trenches, Tonopah Test Range, Nevada, Rev. 0, DOE/NV--827. Las Vegas, NV.

U.S. Department of Energy, National Nuclear Security Administration Nevada Operations Office. 2002b. Industrial Sites Quality Assurance Project Plan, Nevada Test Site, Nevada, Rev. 3, DOE/NV--372. Las Vegas, NV.

U.S. Environmental Protection Agency. 1994. Contract Laboratory Program National Functional Guidelines for Inorganic Data Review, EPA 540-R-94/013. Washington, DC: U.S. Government Printing Office.

U.S. Environmental Protection Agency. 1996. Test Methods for Evaluating Solid Waste, Physical/Chemical Methods, SW-846 CD ROM PB97-501928GEI, which contains updates for 1986, 1992, 1994, and 1996. Washington, DC. 


\section{Appendix C}

Risk Assessment for CAU 410 


\section{C.1.0 Risk Assessment}

A detailed assessment of risk for no action and an evaluation of alternatives was not performed for this CAU because there are no COCs exceeding PALs remaining at the CAU to impact human health or the environment.

Several sample locations had detections of uranium and gamma-emitting isotopes above their associated PALs; however, the concentrations were shown to be indistinguishable from the PALs based on a normalized difference test. Appendix A, Section A.2.7, details the supporting documentation regarding radioisotopes.

Arsenic exceeded the PALs at a few of the soil sample locations at CAU 410. Appendix A, Section A.2.7, details the findings and supporting documentation regarding arsenic. Arsenic levels are elevated at the CAU due to the soils in the region and are not considered a threat to human health or the environment.

No use restrictions are placed on any of the five CASs because any subsurface debris and contaminated soil were excavated and disposed during supplemental characterization activities. 
Appendix D

Closure Activities and Waste Disposition for CAU 410 


\section{D.1.0 Introduction}

This appendix details closure activities that resulted from performing best management practices and waste management (WM) practices for waste generated during the course of supplemental investigation activities at the CASs of CAU 410. This CAU is located at the TTR near Tonopah, Nevada.

During and at the completion of excavation activities at CASs where supplemental field activities were implemented (i.e., CAS 03-19-001, CAS TA-21-002-TAAL, and CAS TA-19-002-TAB2), verification and waste characterization samples were collected and analyzed to support both site characterization and the disposal of IDW generated during supplemental field activities. All samples were analyzed in accordance with the requirements in the CAIP. For waste determinations, analytical results are compared to applicable regulations and disposal site acceptance criteria for hazardous and radiological waste. Analytical data for waste characterization samples are not specifically provided; however, they are maintained in project files and are available upon request. 


\section{D.2.0 Closure Activities}

Closure activities at CAU 410 were conducted as a BMP to properly remove various types of waste generated during characterization activities. The various types of waste consisted of nonhazardous soil and debris, TPH-contaminated soil, depleted uranium-contaminated soil and debris, and UXO. The following sections describe the closure activities and BMP performed over the course of the CAI for each CAS.

\section{D.2.1 CAS TA-21-003-TANL and CAS 09-21-001-TA09, Disposal Trenches}

No closure activities were performed at these two CASs because initial investigation results indicated no COPCs were present above PALs; therefore, no further characterization was required.

\section{D.2.2 CAS TA-19-002-TAB2, Debris Mound}

Initial investigation found DU and UXO; therefore, supplemental field activities were conducted which involved the removal of all debris and contaminated soil in order to properly characterize the subsurface. The segregated waste resulted in stockpiled DU-contaminated soil with miscellaneous debris, a large metal pan, drogue chutes, and various UXO. Figure A.5-1 in Appendix A depicts the type of debris encountered. As a BMP, the waste was not replaced into the excavation but rather, it was disposed as LLW as described in the CAIP ROTC No. 4. The UXO was determined to be either inert (cluster bomb submunitions) or potentially live (one fuze) by USAF EOD personnel. The following closure activities, performed as BMP and WM practices, were completed and no further action is required at this CAS:

- Conducted radiological surveys of debris for waste determination.

- Segregated all UXO from soil and debris and properly disposed by either demilitarization or recycling.

- Collected waste characterization samples for waste determination.

- Loaded DU-waste directly into B25 boxes, 55-gallon drums, and a transportainer in March 2003 to reach subsurface soils for characterization purposes (see Figure D.2-1).

- Stockpiled remaining DU waste in March 2003 for eventual disposal. 


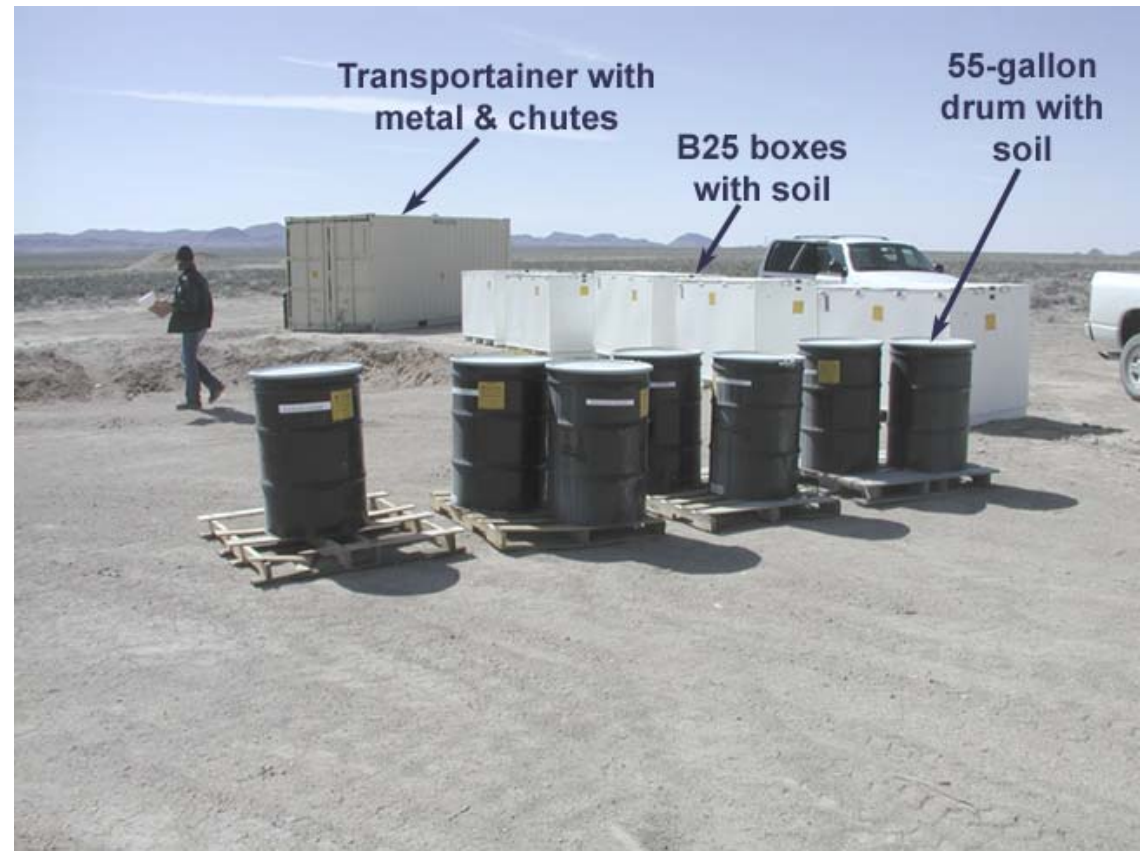

Figure D.2-1

\section{DU-Waste Containers at Bunker 2}

(Photo taken March 2003)

- Loaded remaining DU waste into soft-sided containers in August 2003 for disposal.

- Collected verification samples and analyzed from former locations of metal pan and DU-waste stockpile staging area.

- Transported and disposed approximately 55 tons of LLW to the NTS between August 28 and September 24, 2003.

- Backfilled the excavation on December 2, 2003, with clean sand/gravel from the TTR gravel pit (see Figure D.2-2).

- Transported and disposed of two 55-gallon drums of nonhazardous, nonradioactive solid waste to the U10C disposal site at the NTS on December 3, 2003.

\section{D.2.3 CAS TA-21-002-TAAL, Disposal Trench}

As a BMP, IDW generated during the site characterization of the disposal trench was segregated, stockpiled, and eventually disposed rather than being returned to the excavation due to the large amount of debris and the subsequent identification of DU contamination. One exception to disposal was the soil from Stockpile No. 3. This contaminant-free and relatively debris-free overburden soil 


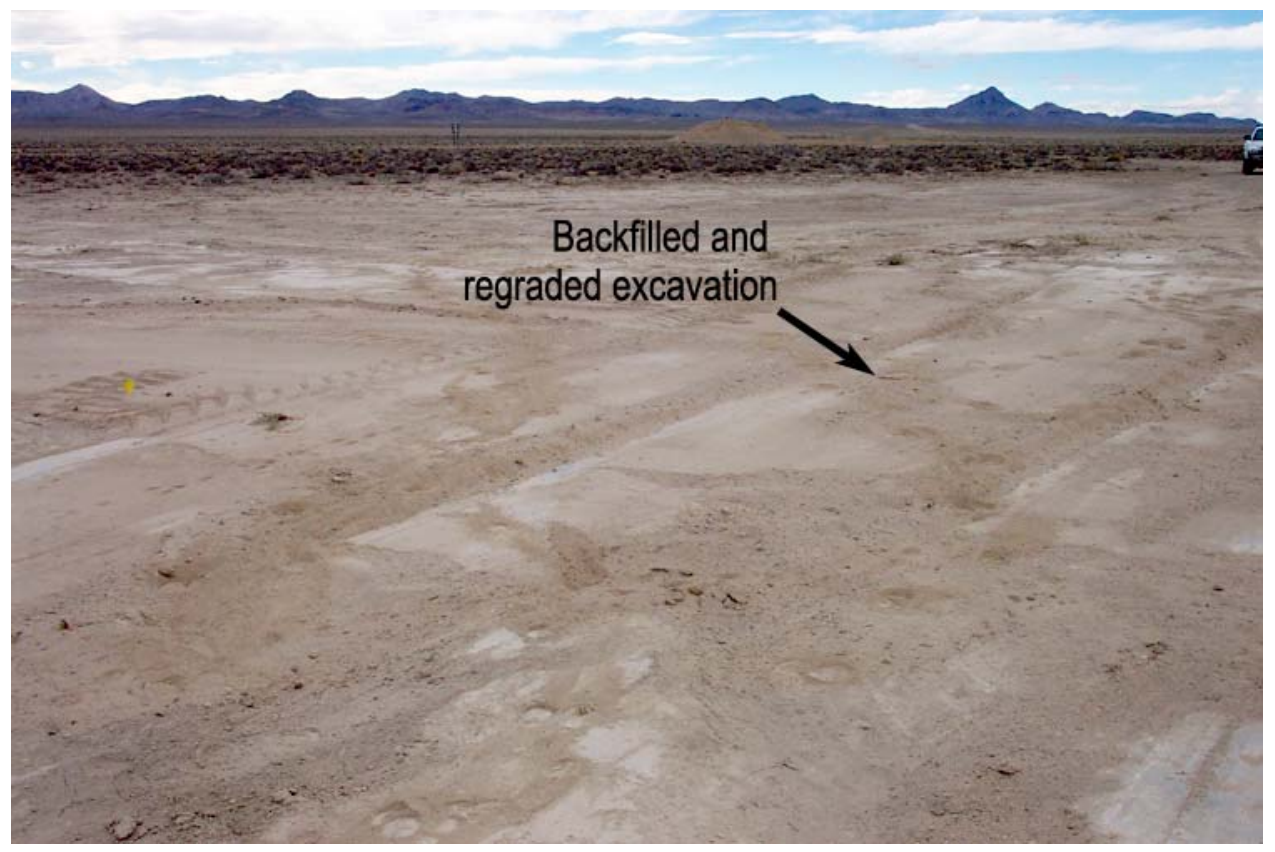

Figure D.2-2

Backfilled Excavation

(Backfilled Excavation at Bunker 2;

Photo taken December 5, 2003)

was used as backfill material. The following closure activities, performed as BMP and WM practices, were completed and no further action is required at this CAS:

- Stockpiled all nonhazardous soil and debris.

- Segregated wire/cable bundles and large scrap metal.

- Stockpiled DU-contaminated soil/debris.

- Stockpiled UXO into HWAAs prior to demilitarization activities.

- Conducted radiological surveys of debris for waste determinations.

- Collected waste characterization samples from all stockpiles for waste determinations.

- Collected verification samples during characterization activities of sidewalls and floor of excavation.

- Backfilled the excavation with clean sand/gravel from the TTR gravel pit (see Figure D.2-3). 
- Disposed nonhazardous aluminum scrap and inert/demilitarized UXO to recycle piles.

- Demilitarized all intact and potentially live UXO (6 separate episodes).

- Disposed approximately 1,600 tons of municipal solid waste to the TTR Piot Construction Landfill (see Figure D.2-4).

- Loaded approximately 65 tons of DU-waste into soft-sided containers in September 2003.

- Transported and disposed approximately 65 tons of LLW to the NTS on September 22 and 23, 2003.

- Collected verification samples from the DU-waste stockpile staging areas after disposal.

- Transported and disposed of one 55-gallon drum of nonhazardous, nonradioactive solid waste to the U10C disposal site at the NTS on December 3, 2003.

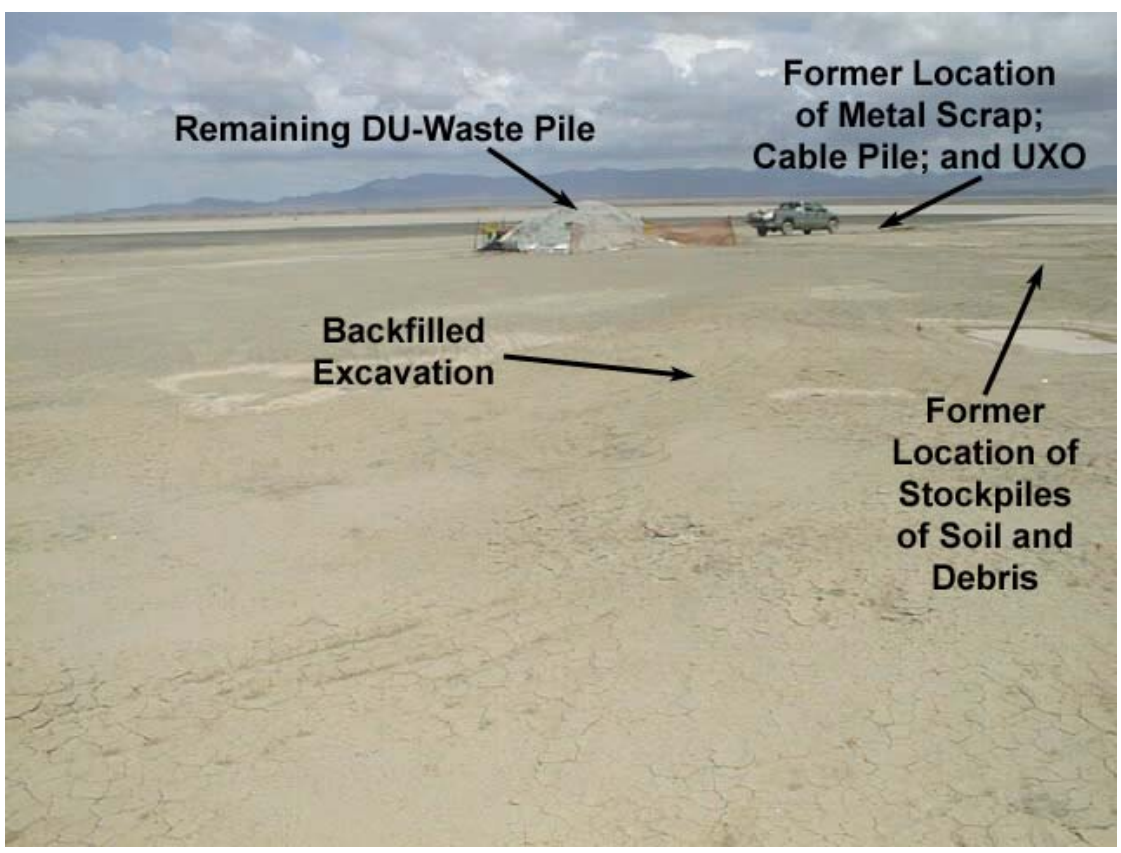

Figure D.2-3

Backfilled Excavation

(Backfilled excavation at Antelope Lake;

Photo taken July 31, 2003) 


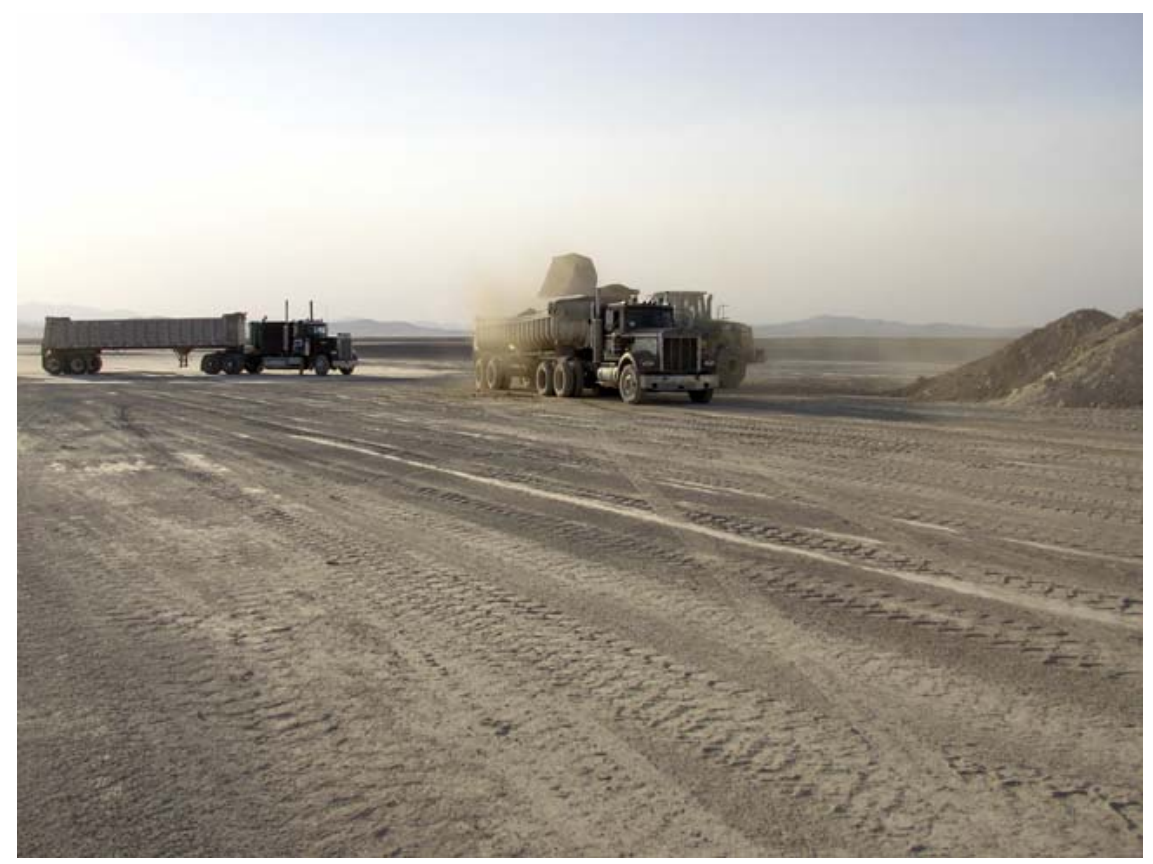

Figure D.2-4

Waste Hauling

(Loading solid municipal waste at Antelope Lake;

Photo taken July 17, 2003)

\section{D.2.4 CAS 03-19-001, Waste Disposal Site}

During the course of characterization activities, a large amount of soil mixed with debris was encountered at this CAS as part of what is referred as the "burn pit." As a BMP, and in order to properly characterize the nature and extent of potential contamination, all debris was excavated from the "burn pit" area. Materials removed from the excavation deemed to have a large percentage of debris was stockpiled for later disposal as nonhazardous waste. Clean overburden or relatively debris-free soil was segregated, when possible, for later use as backfill. Additionally, during the course of determining extent of TPH-contaminated soil in the southern portion of the CAS footprint, all potentially contaminated soil was stockpiled on plastic for eventual disposal. The following closure activities, performed as BMP and WM practices, were completed and no further action is required at this CAS.

- Stockpiled visually stained soil and debris from the burn pit excavation.

- Stockpiled contaminated soil and debris from the TPH excavation. 
- Collected verification samples from sidewalls and floor of the excavation.

- Collected waste characterization samples from soil.

- Disposed approximately 300 tons of municipal solid waste to the TTR Piot sanitary landfill.

- Disposed approximately 230 tons of TPH-contaminated soil and debris to the NTS Area 6 hydrocarbon disposal site.

- Backfilled the excavation with both overburden soil determined clean through field-screening and/or sample analysis and clean sand/gravel from the TTR gravel pit.

- Regraded the surface as close to original grade as possible (see Figure D.2-5 and Figure D.2-6).

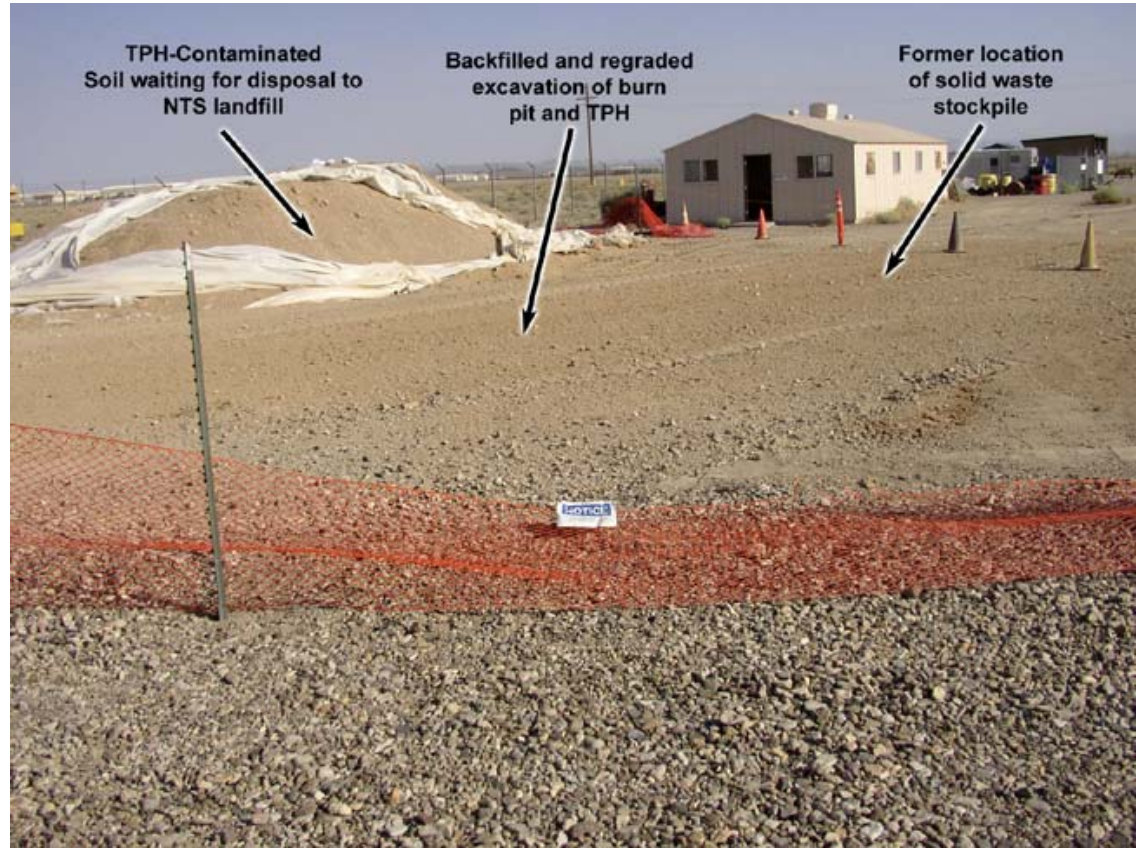

Figure D.2-5

\section{Backfilled Excavation}

(CAS 03-19-002 after solid municipal waste removed and excavation backfilled; Photo taken July 17, 2003)

The BMP closure activities for all CASs were completed by December 3, 2003. These activities performed throughout the CAU 410 corrective action investigation resulted in the removal of all residual contamination or debris in the subsurface; thus, warranting the combination of the CADD and $\mathrm{CR}$ into one report because no further action is recommended at this CAU. 
CAU 410 CADD/CR

Appendix D

Revision: 0

Date: $12 / 22 / 2003$

Page D-8 of D-22

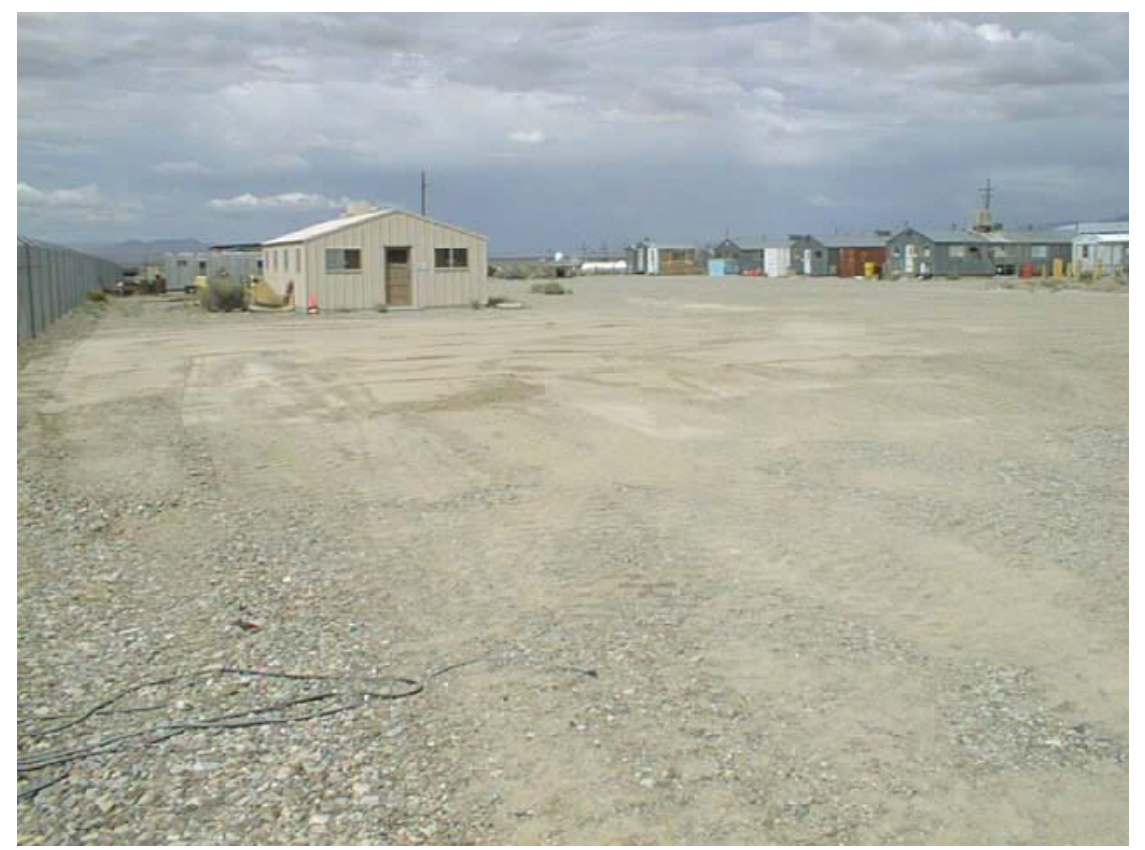

Figure D.2-6

CAS 03-19-001 Closure

(Excavation and hauling of all waste completed;

Photo taken July 31, 2003) 


\section{D.3.0 Waste Management}

Investigation-derived waste was generated during the field activities of CAU 410. The waste streams include decontamination rinse water, disposable personal protection equipment (PPE), fieldscreening waste, disposable sampling equipment, contaminated soil and debris, and UXO. The types, amounts, and disposal of the waste are detailed in the following subsections. Newly generated wastes such as rinsate and PPE/sampling debris (plastic/glass) have been characterized based on the associated soil samples and/or direct sampling (e.g., rinsate). For waste containers not sampled directly, process knowledge and analytical results of corresponding soil samples were used instead.

\section{D.3.1 Waste Minimization}

Corrective Action Unit 410 integrated waste minimization into the field activities. The IDW was segregated to the greatest extent possible. Controls were in place to minimize the use of hazardous materials and unnecessary generation of hazardous and/or mixed waste. Decontamination activities were planned and executed to minimize the volume of rinsate generated.

\section{D.3.2 Waste Characterization}

Analytical results and/or process knowledge for each waste container, stockpile, and/or associated samples were reviewed against federal regulations; state regulations; DOE Directives, Policies, and Guidelines; Waste Disposal Criteria; and standard quality practices.

- The IDW generated by site characterization activities at CAU 410 is a solid waste according to 40 CFR Part 261.2.

- 40 CFR 261.3(a)(2)(iv), 261.4, and 261.6(a)(3) were reviewed to determine if the waste was excluded from regulation as a solid waste or hazardous waste. The waste is not excluded from regulation as a solid waste or hazardous waste.

- Analytical results and knowledge of the waste were used to determine if the waste met criteria as a hazardous waste in Subpart C, "Characteristics of Hazardous Waste," as per 40 CFR 261.24. The soil wastes were not considered hazardous; however, potentially live UXO was managed as D003 hazardous waste during storage because of its potential reactivity and as a mixed waste if the UXO was radioactively contaminated with DU. 
- The F-coded waste discussed in 40 CFR 261.31, "Hazardous Waste From Non-Specific Sources," are applicable to one waste stream. The Petroflag and RDX field-screening kits used for CAU 410 generated spent solvents. As a result, the EPA waste codes F003 and D001 were applied to field-screening waste contained in SAA 41003s01. However, sampling the solvent wastes in drum $41003 \mathrm{~s} 01$ used all remaining waste. Therefore, no disposal was required.

- K-codes as discussed in 40 CFR 261.32, "Hazardous Wastes from Specific Sources," are not applicable to these sites.

- The P- and U-codes as discussed in 40 CFR 261.33, "Discarded Commercial Chemical Products, Off-Specification Species, Container Residues, and Spill Resides Thereof," are not applicable to these sites.

- The Toxic Substances Control Act (TSCA) regulation, which governs the storage and disposal of PCB waste, is not applicable to these sites as PCB analytical results were not above $50 \mathrm{mg} / \mathrm{kg}$ as defined at $40 \mathrm{CFR} 761.3$.

- Based on analytical results and demilitarization activities, no mixed waste was generated at these sites.

- The State of Nevada has set a regulatory action limit for hydrocarbon-impacted soils of $100 \mathrm{mg} / \mathrm{kg}$. The TPH-DRO analytical results for samples at CAS 03-19-001 were compared to this regulatory limit.

- Analytical results and knowledge of the waste were used to determine if the DU-waste met the waste acceptance criteria for the NTS Area 3 and Area 5 RWMS and/or the U10C disposal site.

\section{D.3.2.1 Waste Streams}

The IDW that was generated by site characterization activities at CAU 410 was segregated into the following waste streams:

- Sanitary waste including but not limited to PPE, disposable sample equipment, glass/plastic sample jars, sampling scoops, aluminum foil, and other debris such as plastic sheeting, boxes, sand bags, etc.

- Decontamination rinsate

- Hydrocarbon solids (e.g., soil and debris)

- Municipal solid waste (e.g., soil and debris) 
- Field-screening waste (spent solvents from RDX and TPH kits)

- Ordnance solid waste

- Depleted uranium LLW (e.g., soil and debris)

\section{D.3.2.2 Waste Sampling}

Waste determinations were made utilizing process knowledge and media sample association. Direct sampling was performed to confirm the regulatory status of IDW (i.e., rinsate and stockpiled soil), where necessary.

\section{D.3.3 Storage}

The potentially hazardous and radiological IDW generated at CAU 410 was managed in various ways depending on the nature and volume of the IDW. The types of accumulation and/or storage used for CASs that generated IDW are as follows:

- One Satellite Accumulation Area (SAA) at the Area 3 office for potentially hazardous decontamination rinsate

- One SAA at the Area 3 office for hazardous waste generated by field-screening kits

- At CAS 03-19-001: one HWAA for potentially hazardous decontamination rinsate, one stockpile for municipal solid waste, and one stockpile for solid TPH-contaminated IDW

- At CAS TA-19-002-TAB2: one SAA for the potentially hazardous UXO, one RMA for the DU-contaminated stockpile, one Radiological Controlled Area for two drums staged in Area 3 for solid waste, and U.S. Department of Transportation (DOT)-compliant waste containers to include five B25 boxes, seven 55-gallon drums, and one transportainer for DU waste

- At CAS TA-21-002-TAAL, five separate HWAAs for potentially hazardous UXO, one RMA for radiological IDW, one Radiological Contamination Area (RCA) for the DU-contaminated IDW stockpile, four stockpiles of municipal solid waste, and one RCA for one drum staged in Area 3 for solid waste

Hydrocarbon waste was stockpiled on plastic sheeting and covered with plastic sheeting to prevent run-on and run-off pending disposal. Municipal solid waste was stockpiled and managed as sanitary waste (i.e., no plastic sheeting). Depleted uranium-contaminated waste was not placed on plastic 
sheeting due to the necessity of moving the stockpile while excavating; the stockpile was covered with plastic sheeting pending eventual disposal to prevent run-on/runoff and wind erosion.

All potentially hazardous and/or radiological materials that were stored in 55-gallon DOT specification steel drums were labeled as "Hazardous Waste - Pending Analysis" and/or "Radiological Waste - Pending Analysis." All potentially radioactive materials placed in DOTapproved B25 boxes and the transportainer were labeled as "Radiological Waste - Pending Analysis." The field-screening waste was labeled as "Hazardous Waste" and marked with hazardous waste codes D001 and F003. The amount, type, and source of waste placed into waste containers was recorded in waste management logbooks at each CAS, where applicable.

Due to the risk to worker health and safety in handling UXO waste and as agreed upon by NDEP, ROTC No. 4 was generated for the CAIP. In accordance with ROTC No. 4, UXO suspected of retaining the characteristic of reactivity (i.e., not determined inert by experts) was placed on the ground in a bermed area, cordoned off and posted as either a SAA or HWAA pending demilitarization.

\section{D.3.4 Waste Disposal}

The following paragraphs summarize the types and amounts of waste generated and disposed during the CAU 410 investigation:

- All PPE and disposable sampling equipment generated during site characterization was determined to be sanitary based on observations and process knowledge. The waste was bagged, labelled, and placed in a dumpster for disposal in a sanitary landfill.

- A total of 2 drums of decontamination rinsate were generated and characterized as sanitary waste, as determined through direct sampling. The sanitary waste was disposed at the TTR Area 3 wash down pad.

- One drum of spent solvents from field-screening kits was characterized as F003 and D001 hazardous waste; however, after direct sampling of the drum contents (less than one quart) no existing waste remained for disposal.

- PPE and the decon liner used during packaging operations of DU waste were disposed of within the LLW containers and transported to the NTS. 
- Table D.3-1 summarizes the types of solid waste and materials that were hauled and/or disposed from CAU 410 and consists of the following:

- Approximately 265 tons of soil and debris were characterized as hydrocarbon waste and disposed at the NTS Area 6 hydrocarbon disposal site.

- Approximately 1,910 tons of soil and debris were characterized as municipal solid waste and disposed at the TTR Piot sanitary landfill.

- Approximately 120 tons of soil and debris containerized in 5 B25 boxes, 755 -gallon drums, 1 sealand container, and 11 soft-sided sacks were characterized as LLW and disposed at the Area 3 and Area 5 RWMS at the NTS.

- Three drums of soil IDW were generated during additional soil removal activities in October 2003 and were characterized as sanitary waste. The drums were disposed of in the U10C disposal site at the NTS.

- Based on the opinion of USAF EOD personnel, some of the UXO segregated during characterization activities posed an imminent and substantial endangerment to human health and the environment if left untreated. Therefore, in accordance with 40 CFR 264.1(g)(8)(i)(D) and NDEP approval, the waste UXO was treated in place (i.e., demilitarized), exclusive of RCRA permitting requirements. The number and types of treated waste UXO and the dates of demilitarization are presented in Table D.3-2. The demilitarized UXO scrap was then disposed of in the USAF recycle piles located on range.

- The UXO contaminated with DU required demilitarization to qualify for final disposition into the LLW disposal sites on the NTS (see Table D.3-2). The DU-contaminated UXO scrap was then packaged with other contaminated IDW and disposed of at the Area 3 and Area 5 RWMS at the NTS.

- The UXO determined inert and not contaminated with DU was disposed of in the USAF recycle piles located on range (see Table D.3-3).

- Photo documentation depicting portions of the demilitarization and recycling of CAU 410 UXO is provided in Figure D.3-1 through Figure D.3-4. 
Table D.3-1

Solid Waste Disposal

\begin{tabular}{||c|c|c|c|c||}
\hline \multicolumn{5}{|c|}{ Amount and Dates of CAU 410 Solid Waste Disposal (in Tons) } \\
\hline \multirow{3}{*}{ Hauling/Disposal Date } & \multicolumn{4}{c||}{ Waste Designation } \\
\cline { 2 - 5 } & A3 & AL & HC & DU \\
\hline \hline $5 / 14 / 2003$ & 0 & 3.3 & 0 & 0 \\
\hline $7 / 16 / 2003$ & 301.5 & 0 & 0 & 0 \\
\hline $7 / 17 / 2003$ & 0 & 463.2 & 0 & 0 \\
\hline $7 / 18 / 2003$ & 0 & 228.8 & 0 & 0 \\
\hline $7 / 21 / 2003$ & 0 & 441.5 & 0 & 0 \\
\hline $7 / 22 / 2003$ & 0 & 409.4 & 0 & 0 \\
\hline $7 / 23 / 2003$ & 0 & 61.4 & 69.9 & 0 \\
\hline $7 / 24 / 2003$ & 0 & 0 & 45.6 & 0 \\
\hline $7 / 28 / 2003$ & 0 & 0 & 74.0 & 0 \\
\hline $7 / 29 / 2003$ & 0 & 0 & 74.5 & 20.4 \\
\hline $8 / 28 / 2003$ & 0 & 0 & 0 & 98.6 \\
\hline $9 / 24 / 2003$ & 0 & 0 & 0 & 119.0 \\
\hline TOTAL Tons & $\mathbf{3 0 1 . 5}$ & 1607.6 & $\mathbf{2 6 4 . 0}$ & 79.4 \\
\hline Volume (yd $\left.{ }^{3}\right)^{1}$ & 201.0 & 1071.733 & 176.0 & 0 \\
\hline & & & & 0 \\
\hline
\end{tabular}

${ }^{1}$ Volume calculated by dividing tonnage by 1.5 factor

A3 = Area 3 solid waste hauled to TTR landfill

$\mathrm{AL}=$ Antelope Lake solid waste hauled to TTR landfill

$\mathrm{HC}=$ Hydrocarbon waste hauled to NTS landfill

DU = Low-level waste hauled to NTS landfill; the dates reflect the date of transport off-site, not the dates of waste loading into containers 
Table D.3-2

UXO Demilitarization Activities for CAU 410

\begin{tabular}{|c|c|c|c|c|c|c|}
\hline & April 24, 2003 ${ }^{1}$ & May $1,2003^{2}$ & May $13,2003^{3}$ & June $25,2003^{4}$ & July $17,2003^{5}$ & September $11,2003^{6}$ \\
\hline \multirow{5}{*}{$\begin{array}{c}\text { Types and } \\
\text { Number of } \\
\text { UXO }\end{array}$} & 11 - Mark 82 & $\begin{array}{l}1-155 \mathrm{~mm} \\
\text { round }\end{array}$ & 3 - Mark 82 & \multirow{5}{*}{59 - BLU 63} & \multirow{5}{*}{61 - BLU 63} & \multirow{5}{*}{13 - BLU 63} \\
\hline & 2 - Unknown & $\begin{array}{l}\text { 1- } 105 \mathrm{~mm} \\
\text { round }\end{array}$ & 7 - beehives & & & \\
\hline & $\begin{array}{l}1 \text { - 5-inch } \\
\text { rocket }\end{array}$ & \multirow{3}{*}{44 - BLU-63 } & $\begin{array}{l}1-155 \mathrm{~mm} \\
\text { round }\end{array}$ & & & \\
\hline & \multirow[b]{2}{*}{2 - drill round } & & 1 - Fuze & & & \\
\hline & & & $\begin{array}{c}35 \text { - cluster } \\
\text { bomb } \\
\text { submunitions }\end{array}$ & & & \\
\hline
\end{tabular}

${ }^{1}$ Demilled portions of UXO from Antelope Lake from original excavation recovery

${ }^{2}$ Demilled portions of UXO from Antelope Lake from original excavation recovery

${ }^{3}$ Demilled all DU-contaminated UXO from Antelope Lake and Bunker 2

${ }^{4}$ Demilled UXO recovered during second screening of Stockpile No. 1

${ }^{5}$ Demilled UXO recovered during second screening of Stockpiles No. 2 and No. 4

${ }^{6}$ Demilled UXO recovered during second screening of DU-waste pile at Antelope Lake

NA = Not applicable

Table D.3-3

Disposal of Inert UXO for CAU 410

\begin{tabular}{|c|c|c|c|}
\hline \multicolumn{4}{|c|}{ Inert Ordnance Transferred to U.S. Air Force Recycle Piles } \\
\hline & April 28, 2003 & July 31, 2003 & September 11, 2003 \\
\hline \multirow{6}{*}{$\begin{array}{c}\text { Types and Number } \\
\text { of UXO }\end{array}$} & 774 - beehives & 20 - beehives & 3 - beehives \\
\hline & $\begin{array}{l}97 \text { - cluster bomb } \\
\text { submunitions }\end{array}$ & 4 - dispensers & $\mathrm{N} / \mathrm{A}$ \\
\hline & 4 - SUSS rounds & $\mathrm{N} / \mathrm{A}$ & $\mathrm{N} / \mathrm{A}$ \\
\hline & 8 - TDD fuzes & $\mathrm{N} / \mathrm{A}$ & $\mathrm{N} / \mathrm{A}$ \\
\hline & 3 - Mark 84 & $\mathrm{~N} / \mathrm{A}$ & $\mathrm{N} / \mathrm{A}$ \\
\hline & 1 - 2,000-pound sea mine & $\mathrm{N} / \mathrm{A}$ & $\mathrm{N} / \mathrm{A}$ \\
\hline
\end{tabular}

$\mathrm{NA}=$ Not applicable 


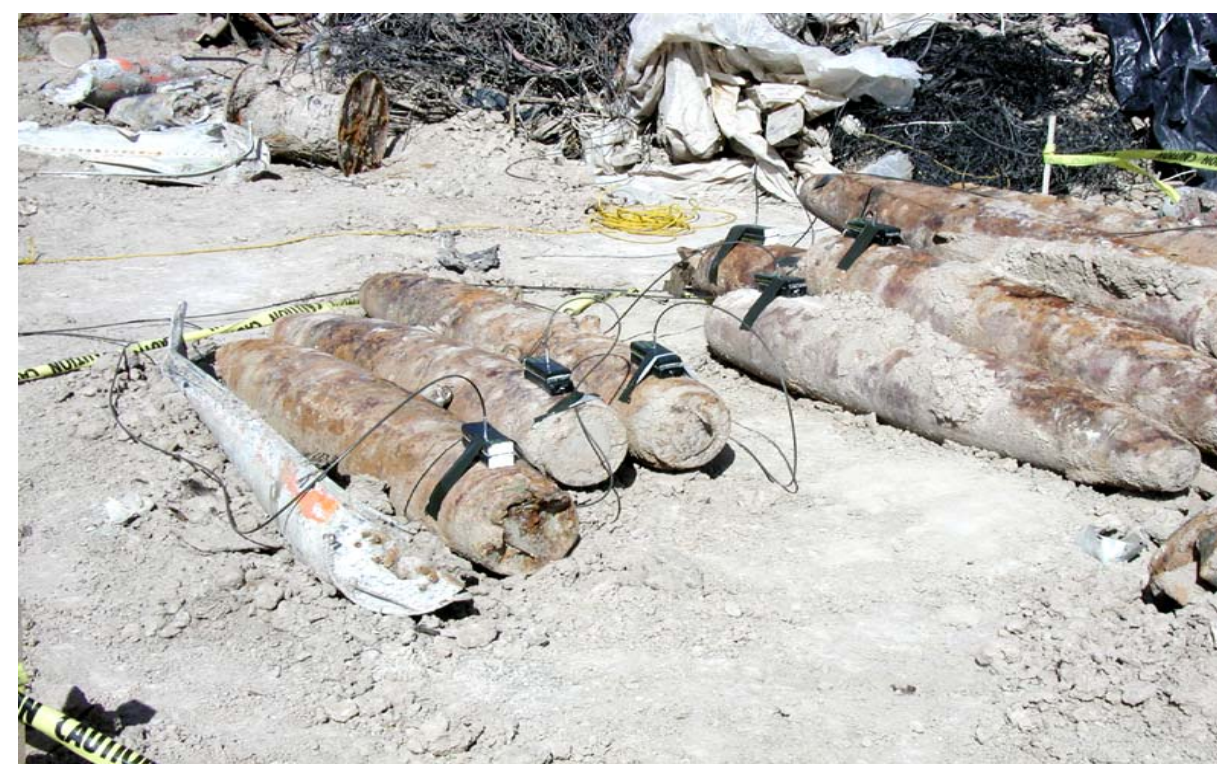

a. Mark-82s prior to demilitarization (Photo taken April 24, 2003)

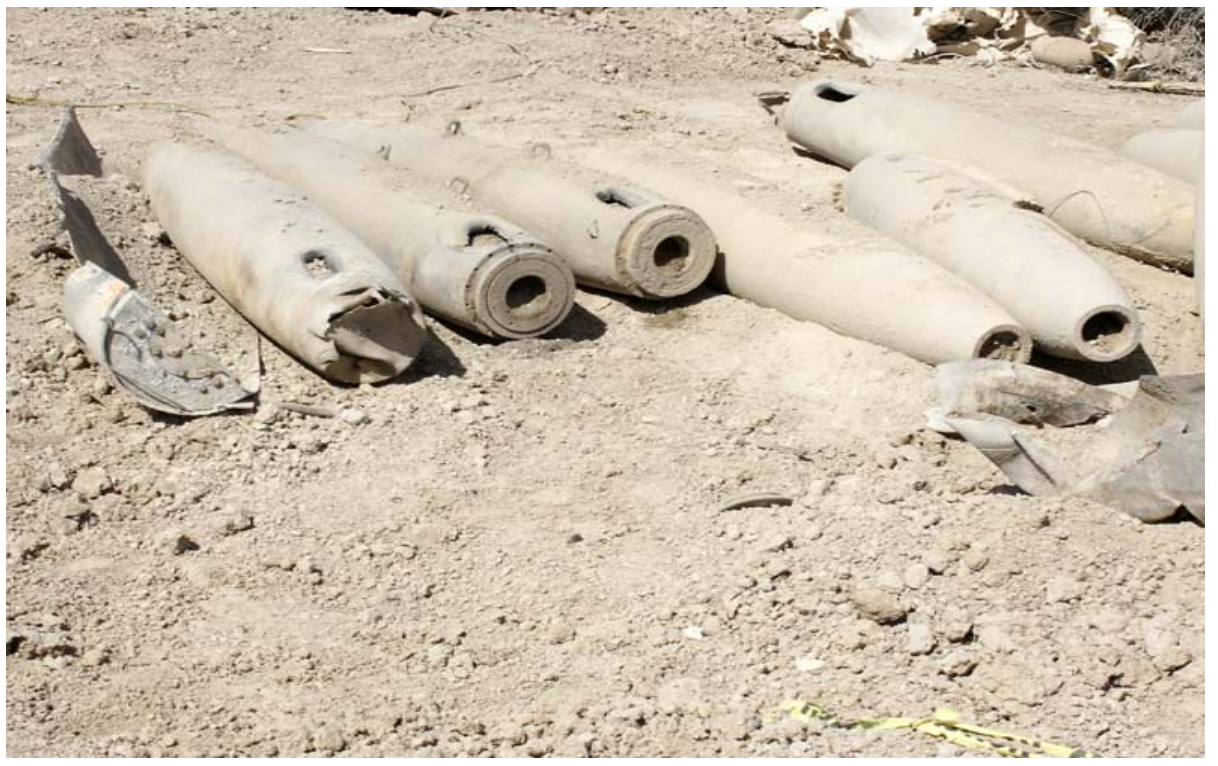

b. Mark-82s after demilitarization

(Photo taken April 24, 2003) 


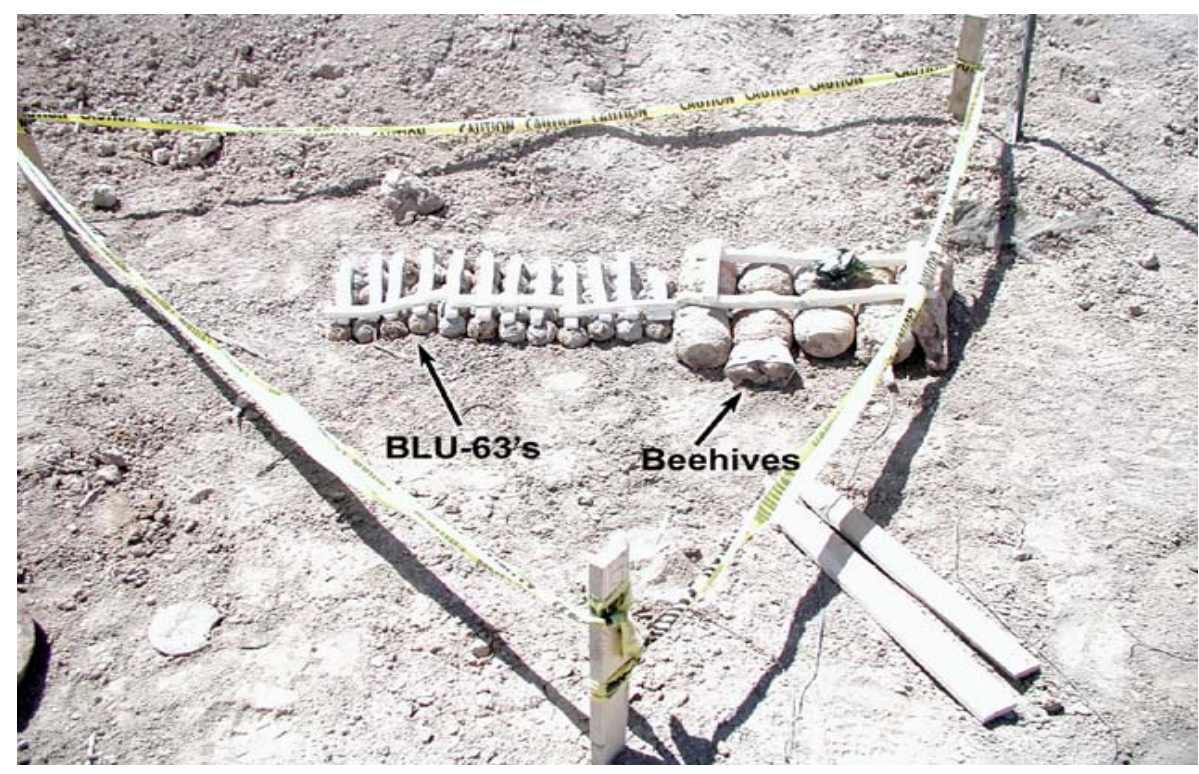

a. Small UXO with C-4 explosive prior to demilitarization

(Photo taken June 25, 2003)

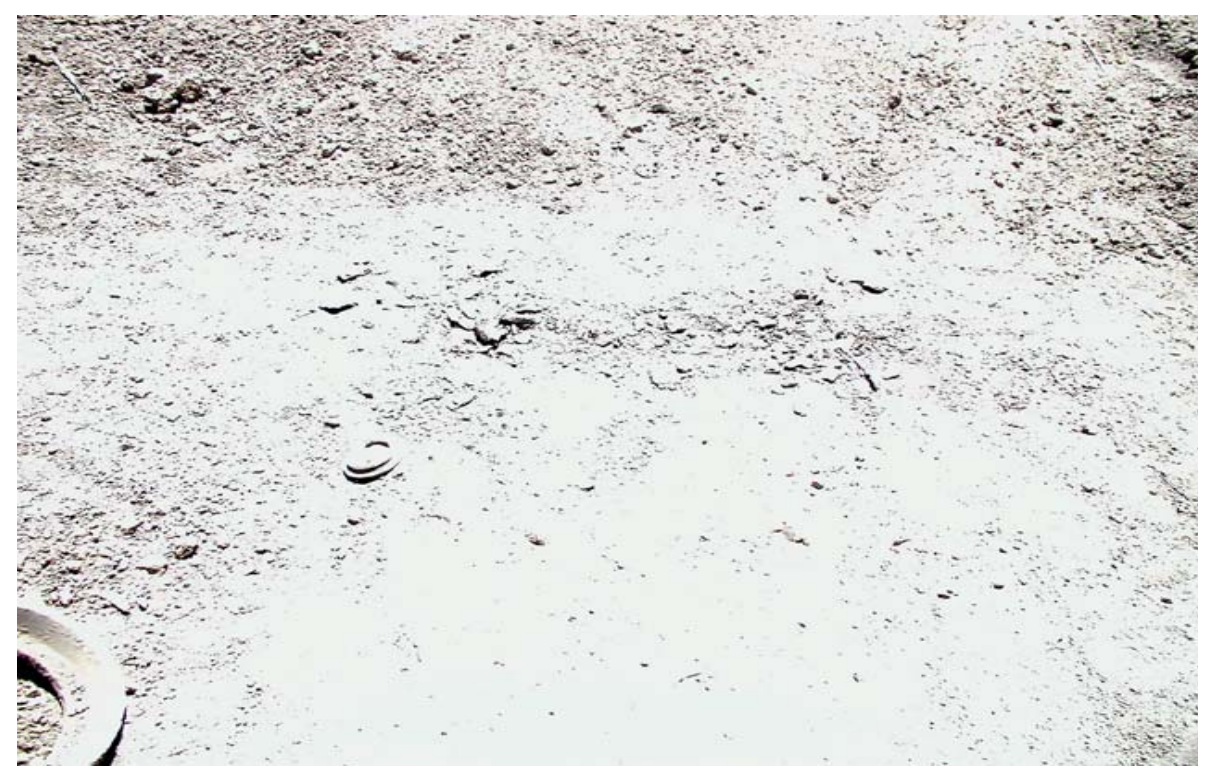

b. Remains of small UXO after demilitarization

(Photo taken June 25, 2003) 


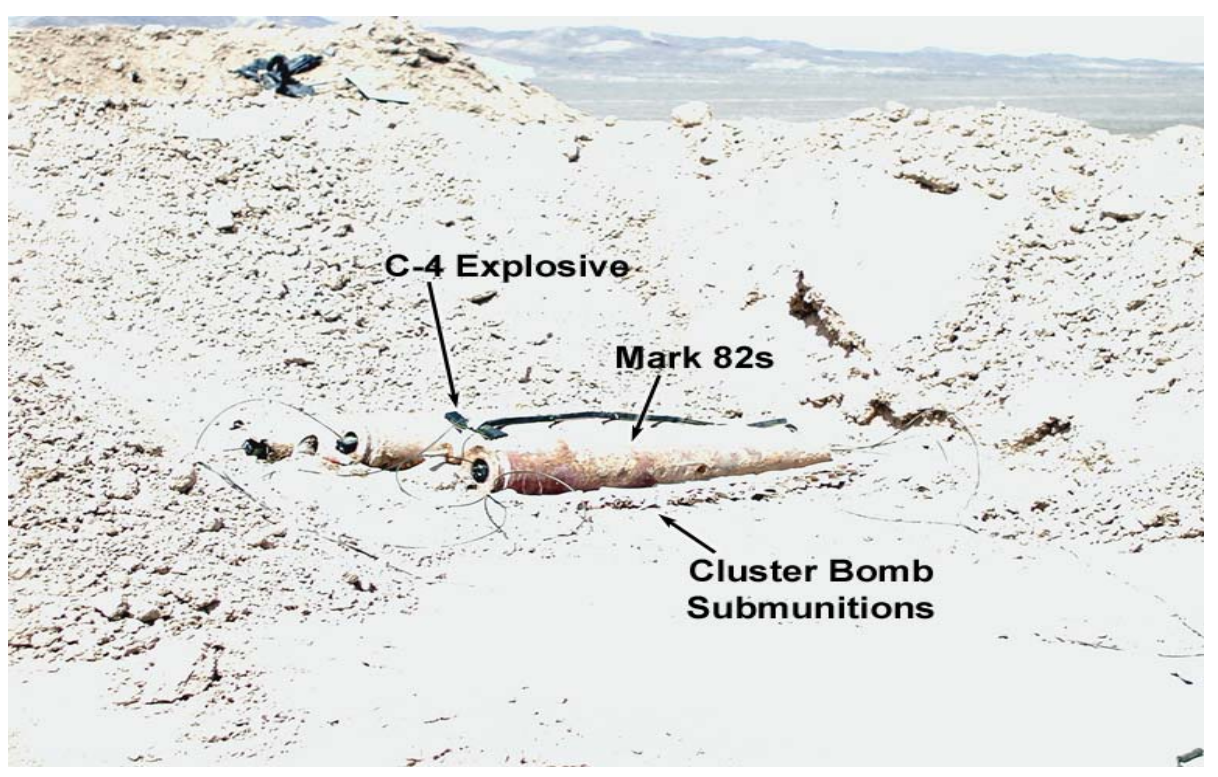

a. DU-contaminated UXO prior to demilitarization

(Photo taken May 13, 2003)

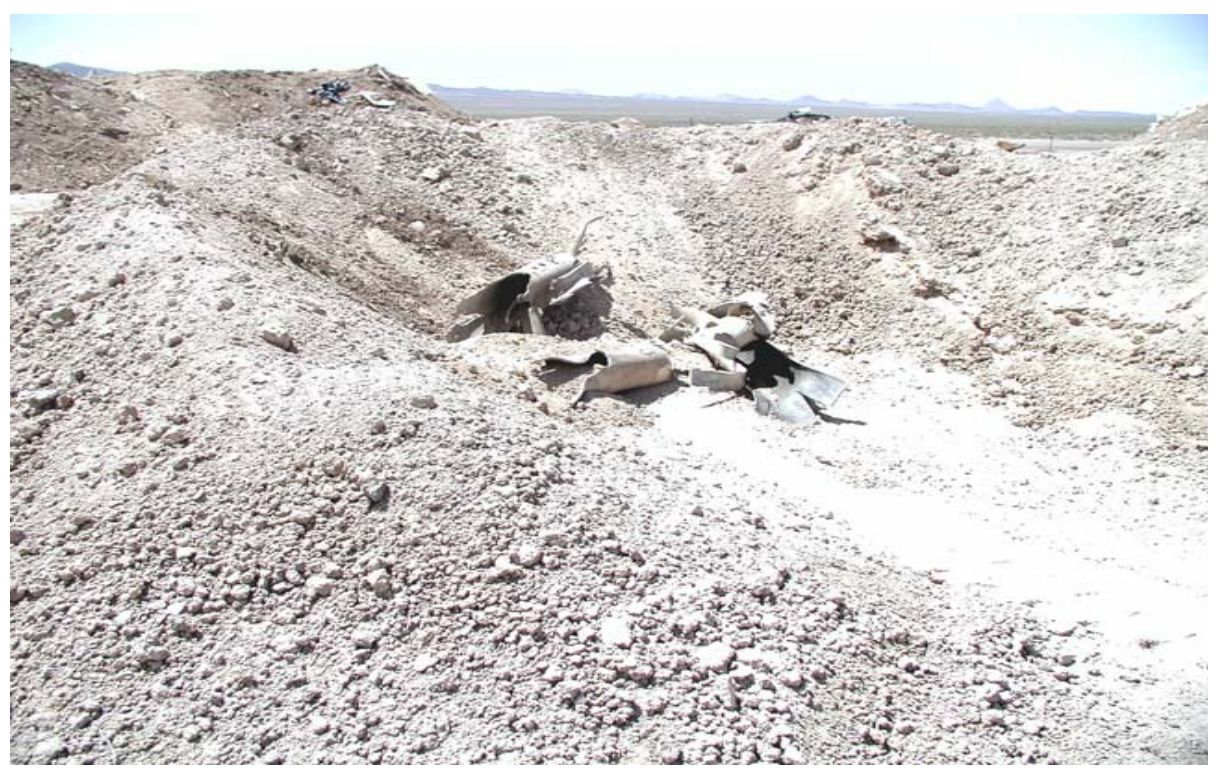

b. DU-contaminated UXO after demilitarization

(Photo taken May 13, 2003)

Figure D.3-3

Demilitarization of DU-Contaminated UXO at Antelope Lake 


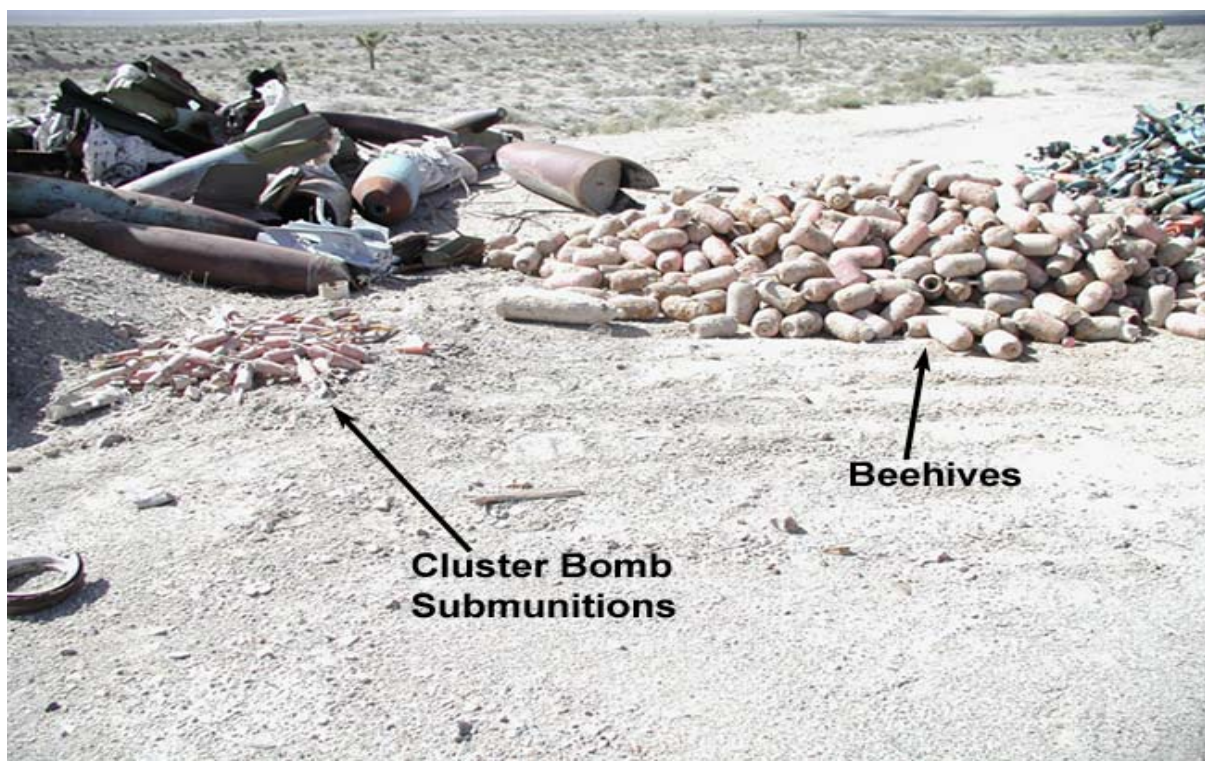

a. Photo taken April 28, 2003

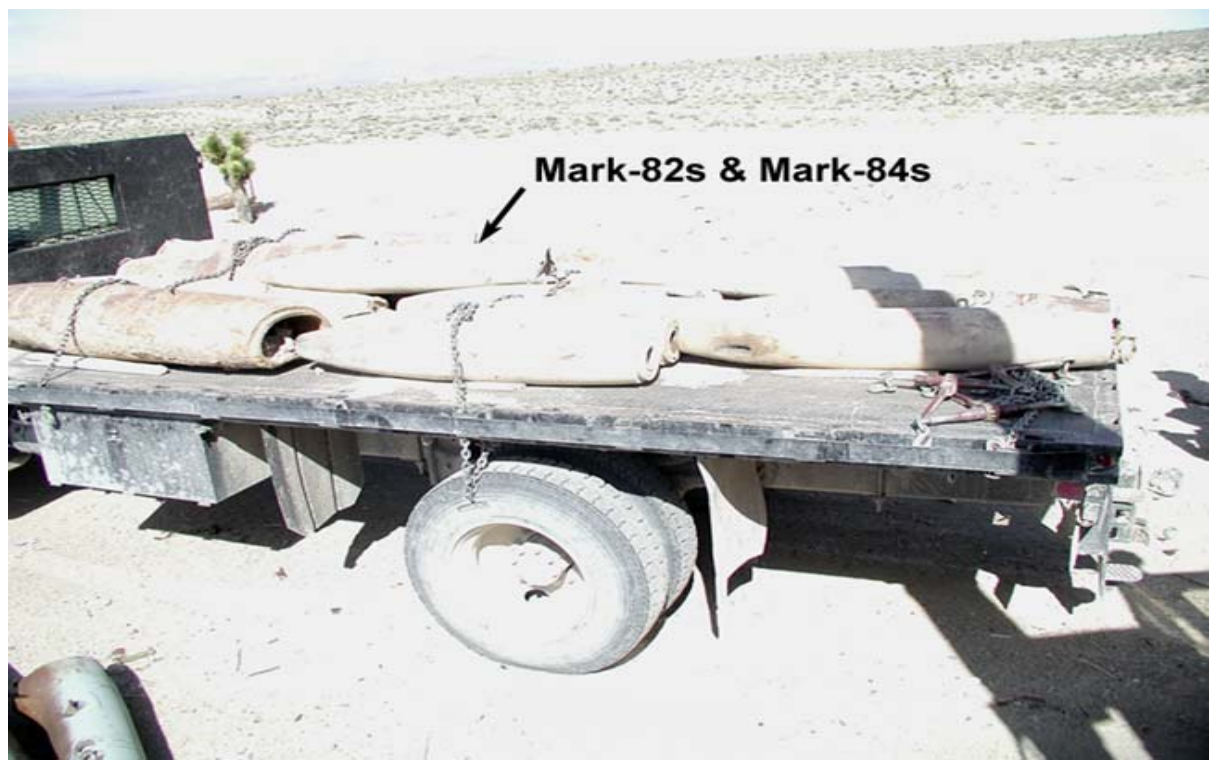

b. Photo taken April 28, 2003

Figure D.3-4

Inert UXO Transported to Recycle Pile on Range 


\section{D.4.0 Verification Sample Analyses}

This section summarizes the results of verification sampling conducted during supplemental field activities at CAU 410. In the process of accessing subsurface sampling locations to adequately define the nature and extent of contamination during supplemental field activities, all removed soil, debris, and UXO were disposed as solid waste rather than being replaced into the excavation. Due to this BMP, verification samples were collected from sidewalls and floors of excavations to provide closure documentation at the following three CASs: TA-19-002-TAB2 (Bunker 2), TA-21-002-TAAL (Antelope Lake), and 03-19-001 (Area 3). For excavations up to $4 \mathrm{ft}$ deep, samples were collected by hand or backhoe. At excavations over $4 \mathrm{ft}$ deep or inaccessible by foot, verification samples were collected from the backhoe bucket or hollow-stem auger rig.

Additional verification samples were collected from the ground surface following the disposal of stockpiled DU-waste at the Bunker 2 and Antelope Lake sites to confirm all contaminated soils above PALs were removed. These samples were collected by hand.

\section{D.4.1 CAS TA-19-002-TAB2}

Details regarding verification sampling and analytical results for this CAS are presented in Appendix A, Section A.5.0. Verification sample locations are shown in Figure A.5-3. Samples 410B2007 through 410B2013 and sample 410B2024 represent the samples collected on the sidewalls and floor of the excavation. Samples 410B2009 and 410B2013 indicated elevated DU was still present in the eastern sidewall. Additional soil was removed and the sidewall resampled (410B2024) with analytical results indicating concentrations below PALs. Upon verification, the excavation was backfilled with clean sand and gravel on December 2, 2003.

Following the loading of the DU waste stockpile into waste containers, one of the initial two verification samples (410B2014) indicated residual contamination remained above PALs. Additional soil was removed from the surface on October 14 and 22, 2003, and another nine verification samples and one field duplicate were collected and analyzed (see Figure A.5-3). The analytical results were not statistically greater than PALs using the normalized difference test. Based on the verification analytical results, no further soil removal was required at CAS TA-19-002-TAB2. 


\section{D.4.2 CAS TA-21-002-TAAL}

Details regarding verification sampling and analytical results for this CAS are presented in Appendix A, Section A.6.0. Verification sample locations are shown in Figure A.6-1. Sixteen verification samples numbered 410AL001 through 410AL016 represent the samples collected from the sidewalls and floor of the excavation. The analytical results indicate that the remaining subsurface soil has concentrations below PALs. Upon verification, the excavation was backfilled with clean sand and gravel.

Following the loading and disposal of the DU-waste stockpile into containers, four initial verification samples (410AL017 to 410AL020) were collected from the ground surface. One of the four samples (410AL018) indicated residual contamination remained above PALs. Additional soil was removed from the surface on October 14, 2003, and another eight verification samples and one field duplicate were collected and analyzed (see Figure A.6-2). The analytical results were not statistically greater than PALs using the normalized difference test. Based on these verification analytical results, no further soil removal is required at CAS TA-21-002-TAAL.

\section{D.4.3 CAS 03-19-001}

Details regarding verification sampling and analytical results for this CAS are presented in Appendix A, Section A.7.0. Verification sample locations are shown in Figure A.7-5 and Figure A.7-6. A total of 10 verification samples (41003011 to 41003014 and 41003024 to 41003029 ) were collected during the investigation that represent the sidewalls and the floor of the burn pit area. All verification analytical results indicate there are no COPCs remaining in the burn pit area.

A total of 21 verification samples (41003016 to 41003023 and 41003030 to 41003042 ) were collected during the supplemental investigation that represent the sidewalls and floor of the TPH area. Verification analytical results indicate that the remaining soil in the TPH area of the CAS is below the NDEP action levels for TPH-DRO (100 mg/kg). Based on the verification analytical results, no further subsurface soil removal was required at either the burn pit or TPH area of CAS 03-19-001. Upon verification, the excavation was backfilled with clean sand and gravel. 


\section{D.5.0 Summary}

Closure activities were completed at CAU 410 by:

- Removing and disposing of solid material (soil and/or debris) impacted by TPH-DRO or depleted uranium.

- Removing, segregating, and disposing of solid material containing large amounts of debris.

- Screening and segregating UXO from soil and debris.

- Demilitarization of potentially live UXO by USAF EOD personnel.

All solid waste that was deemed not suitable for use as backfill was disposed in accordance with applicable waste regulations as outlined in the CAIP:

- Solid waste impacted by TPH was disposed at the NTS hydrocarbon landfill.

- Solid waste impacted by depleted uranium was disposed at the Area 3 and Area 5 RWMS or the U10C disposal site.

- Municipal solid waste determined to be nonhazardous was disposed in the Piot Landfill at the TTR.

- Nonhazardous, recyclable metal scrap and inert/demilitarized UXO were disposed at the USAF recycle piles located on range.

Verification samples from sidewalls and floors of the excavations and the ground surface where contaminated soils were stockpiled were collected and met the established closure criteria.

All excavations were backfilled with clean fill taken from the TTR gravel pit and regraded as close to the original slope as possible.

It is anticipated, based on the work completed, that the site can be closed without further corrective action requirements. 


\section{Appendix E}

Waste Manifests for CAU 410

(74 Pages) 


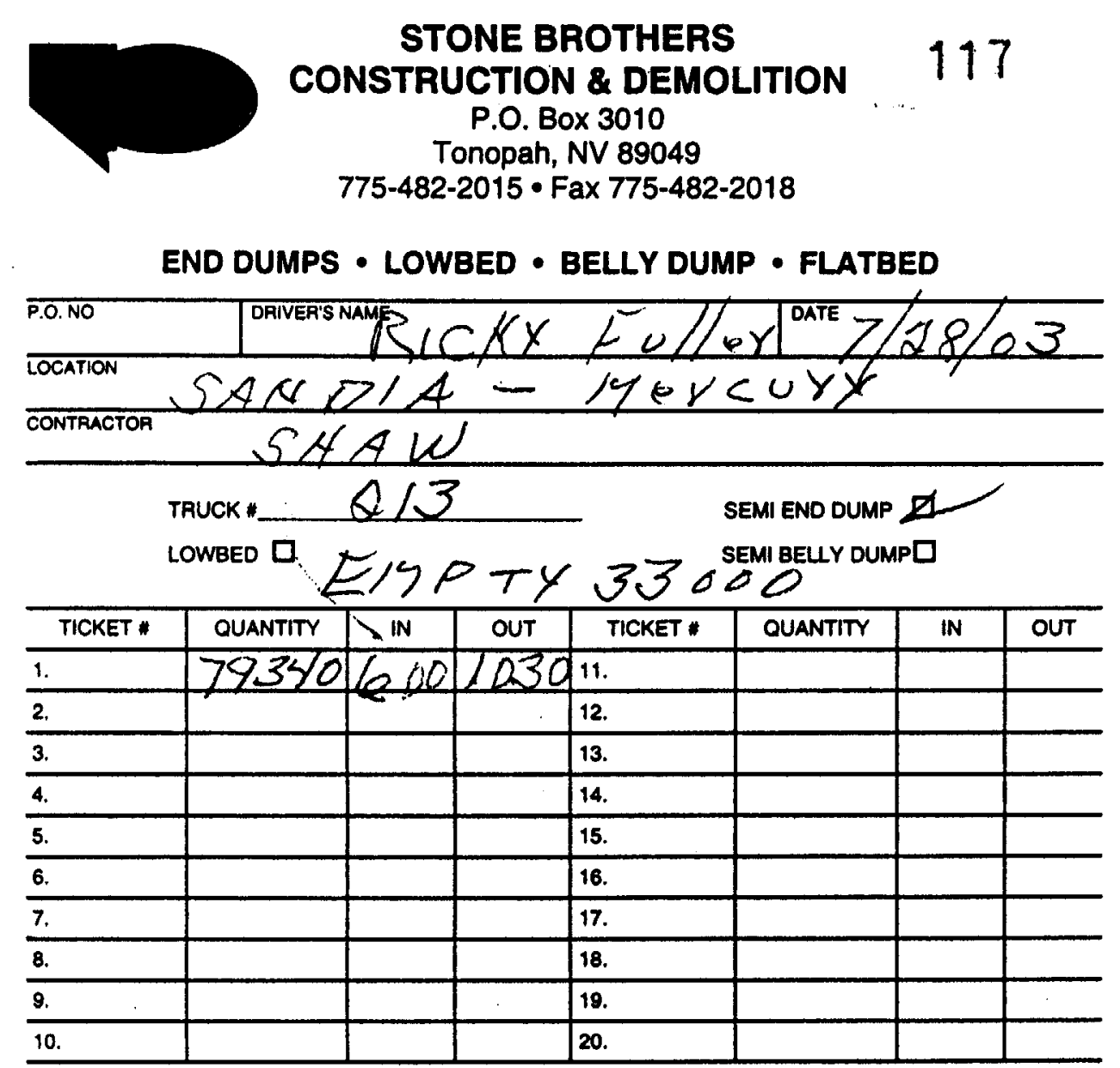

START TIME $6 \& M$ LUNCH TIME $\angle O O-130$ DOWNTIME STOP TIME 廿а́弓 STAND BY TOTAL TIME $\angle 0$ REMARKS:

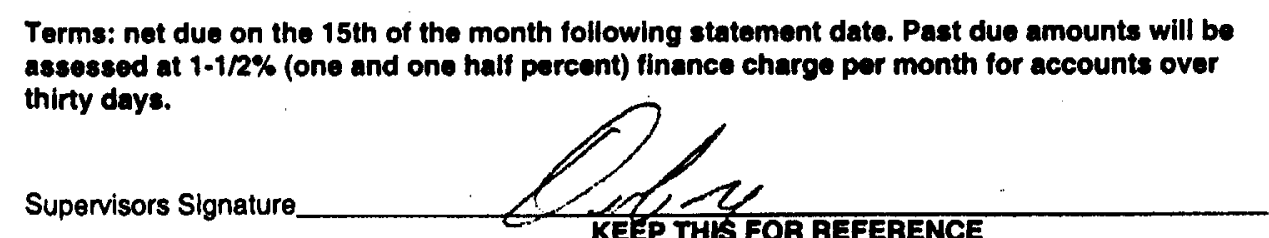
Terms: net due on the 15th of the month following statement date. Past due amounts will be thirty days.

Tonopah, NV 89049

$775-482-2015 \cdot$ Fax 775-482-2018

END DUMPS - LOWBEb': BELLY

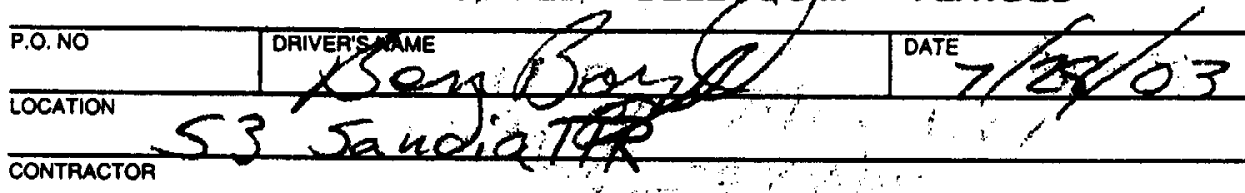

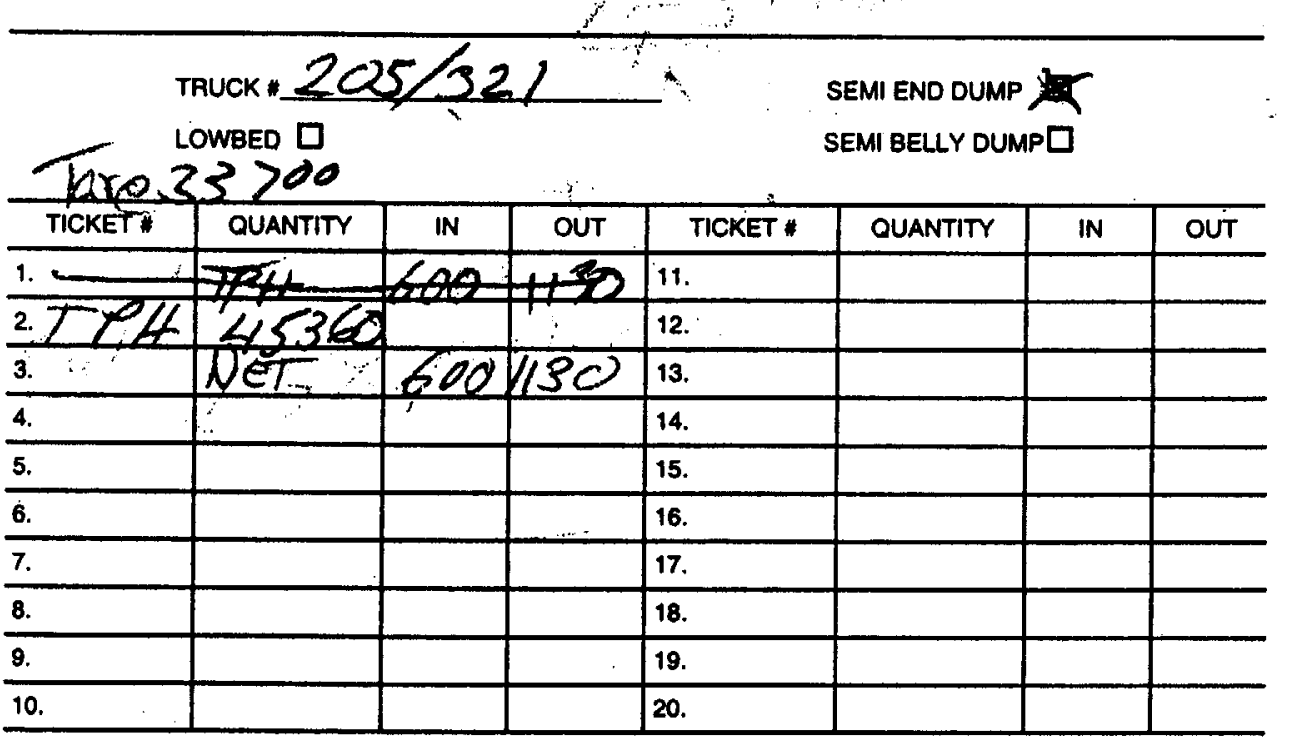

START TIME_ 60

LUNCH TIME

DOWNTIME
STOP TIME

STANDBY

TOJAL TIME
REMARKS

Terms: net due on the 15 th of the month following statement date. Past due amounts will be assessed at $1-1 / 2 \%$ (one and one half percent) finance charge per month for accounts over thirty days.

Supervisors Signature

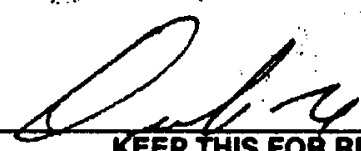




\section{STONE BROTHERS CONSTRUCTION \& DEMOLITION \\ P.O. Box 3010}

Tonopah, NV 89049

775-482-2015 - Fax 775-482-2018

END DUMPS - LOWBED - BELLY DUMP - FLATBED

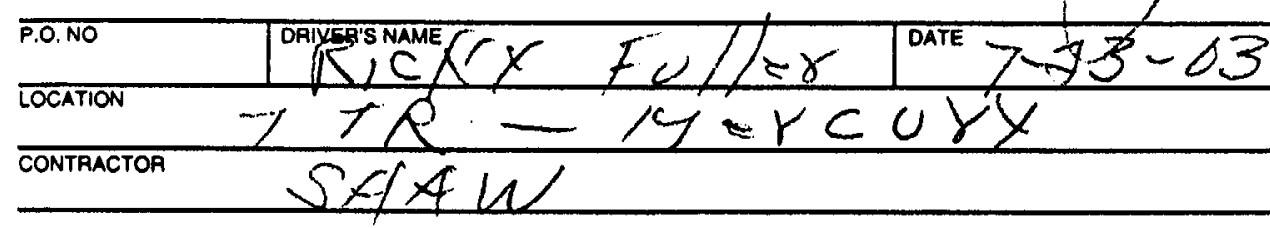
TRUCK: 713

W... LOWBED $\square$

$33,000-T A R E$

SEMI END DUMP A

SEMI BEUY DUMPD

\begin{tabular}{|c|c|c|c|c|c|c|c|}
\hline TICKET * & QUANTITY & IN & OUT & TICKET * & QUANTITY & IN & OUT \\
\hline $17 P / 60$ & $7 P 4$ & 955 & 300 & 11. & & & \\
\hline 2. & & & & 12. & & & \\
\hline 3. & & & & 13. & & & \\
\hline 4. & & & & 14. & & & \\
\hline 5. & & & & 15. & & & \\
\hline 6. & & & & 16. & & & \\
\hline 7. & & & & 17. & & & \\
\hline 8. & & & & 18. & & & \\
\hline 9. & & & & 19. & & & \\
\hline 10. & & & & 20. & & & \\
\hline
\end{tabular}

StaRt TIME qIGO

LUNCH TIME YS hY LUNCH

DOWNTIME

STOP TIME 730

STAND BY

TOTAL TIME

REMARKS:

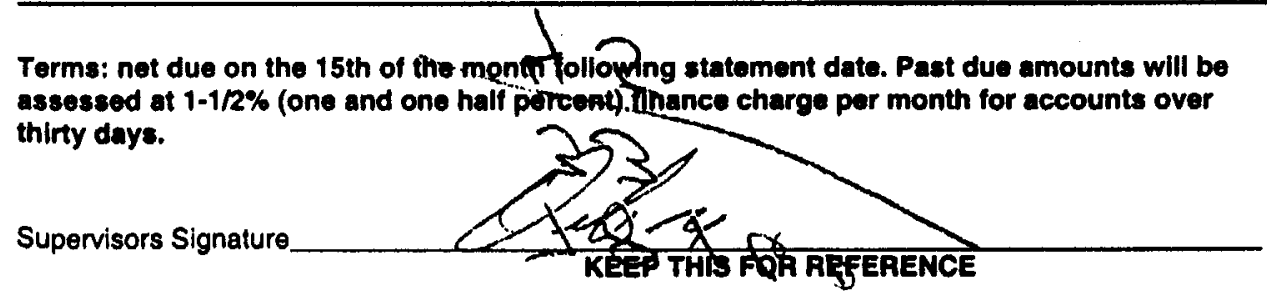

STONE BROTHERS CONSTRUCTION \& DEMOLITION

P.O. Box 3010

Tonopah, NV 89049

$775-482-2015$ - Fax 775-482-2018

END DUMPS - LOWBED • BELLY DUMP • FLATBED

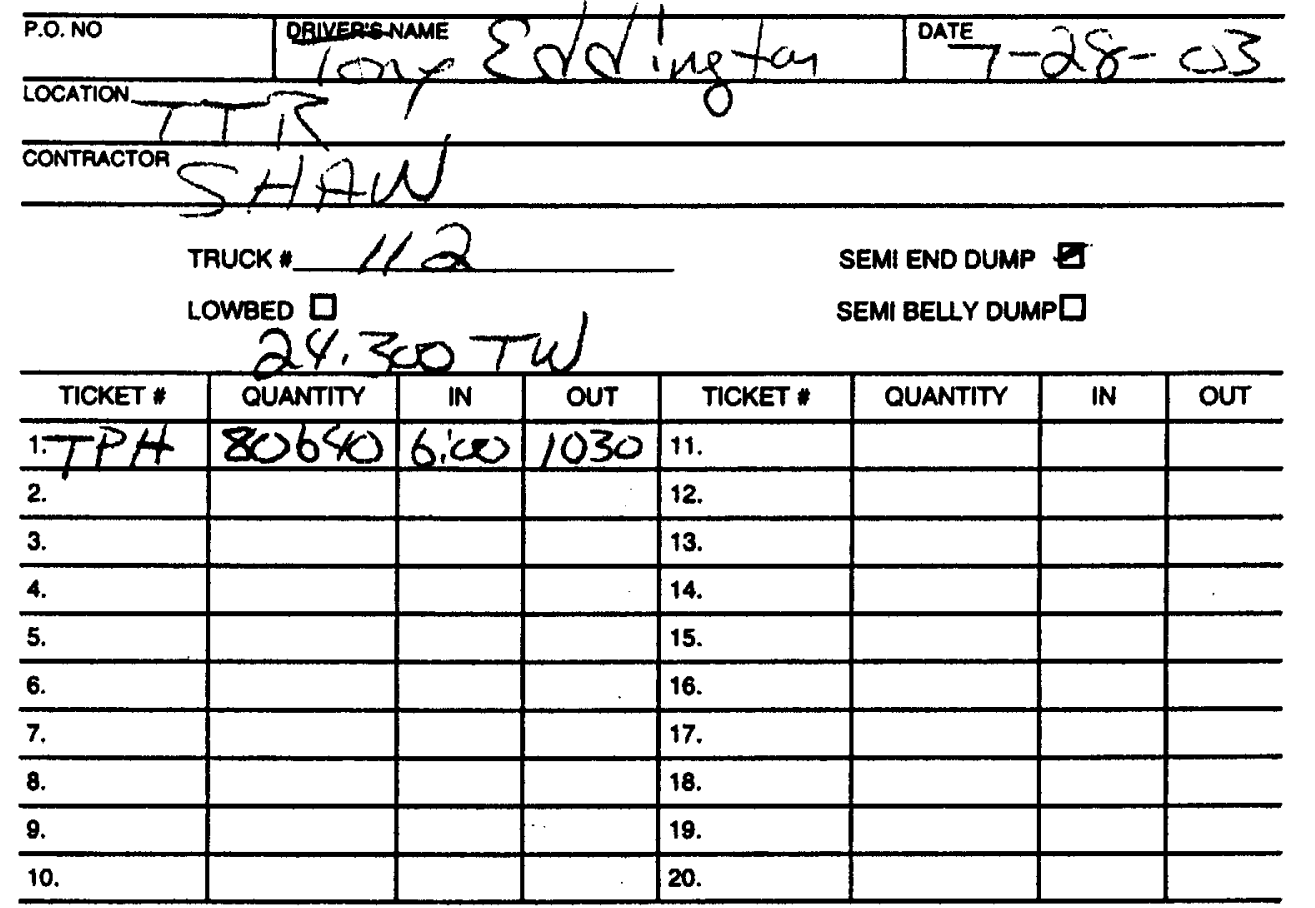

START TIME 0600 LUNCH TIME li3O-2;00 DOWNTIME_

STOP TIME $4: 30$ STANDBY TOTAL TIME $/ 0$

REMARKS:

Terms: net due on the 15th of the month following statement date. Past due amounts will be assessed at 1-1/2\% (one and one half percent) finance charge per month for accounts over thinty days.

Supervisors Signature 


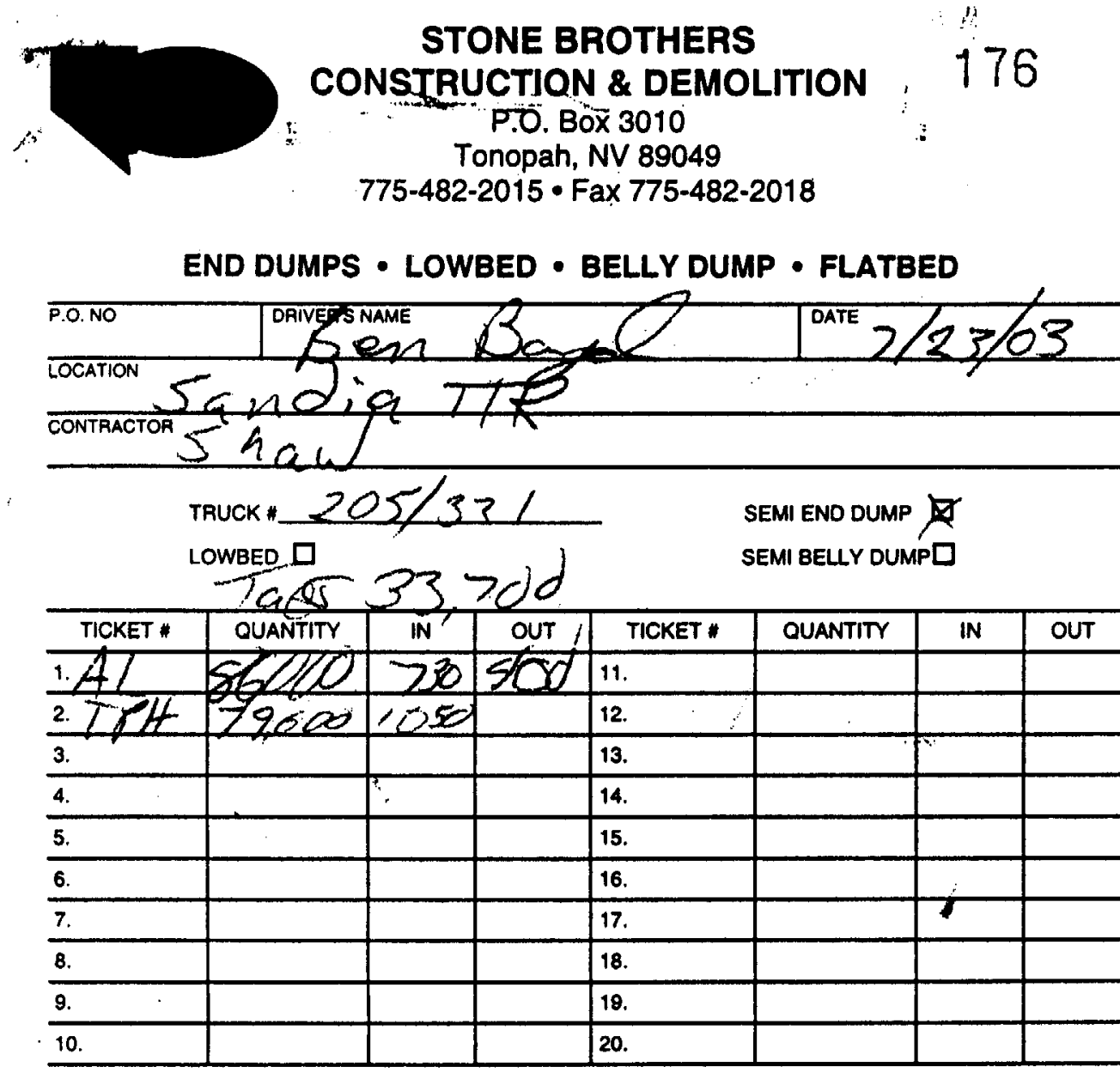

START TIME 600

LUNCH TIME

DOWNTIME

REMARKS: $)^{\prime} R \in(A b)$ Tfh to m grour 2 Ebts vaw vat Ration Todach

mike wastosigk an $3 / 24 / 03$

Terms: net due on the 15th of the month following statement date. Past due amounts will be assessed at $1-1 / 2 \%$ (One and one half percent) finance charge per month for accounts over thirty days.

Supervisors Signature

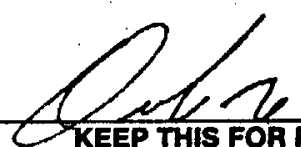

\section{STONE BROTHERS}

CONSTRUCTION \& DEMOLITION

P.O. Box 3010

Tonopah, NV 89049

$775-482-2015 \cdot$ Fax 775-482-2018

END DUMPS • LOWBED ・ BELLY DUMP • FLATBED

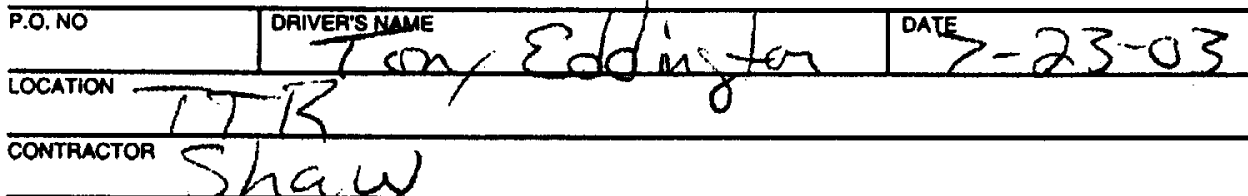

тRUCK* $1 / 2$

LOWBED $\square$

$04.30 \times+41$

\begin{tabular}{l|l|l|l|l|}
\hline TICKET * & QUANTIT & IN & OUT \\
\hline TPH & 73.160 & 9.47 & & \\
\hline 2. & & & & \\
\hline 3. & & & & \\
\hline 4. & & & & \\
\hline 5. & & & & \\
\hline 6. & & & & \\
\hline 7. & & & & \\
\hline 8. & & & & \\
\hline 9. & & & & \\
\hline 10. & & & & \\
\hline
\end{tabular}

StART TIME 0900

LUNCH TIME

DOWN TIME
SEMI END DUMP D-

SEMI BELLY DUMPD

\begin{tabular}{|l|l|l|l}
\hline TICKET * & QUANTITY & IN & OUT \\
\hline 11. & & & \\
\hline 12. & & & \\
\hline 13. & & & \\
\hline 14. & & & \\
\hline 15. & & & \\
\hline 16. & & & \\
\hline 17. & & & \\
\hline 18. & & & \\
\hline 19. & & & \\
\hline 20. & & & \\
\hline \multicolumn{4}{|c|}{$7: 30$} \\
\hline
\end{tabular}

STAND BY

TOTAL TIME $/(\mathcal{Q})$
REMARKS

Terms: net due on the 15th of the month following statement date. Past due amounts will be assessed at 1-1/2\% (one and one half percent) finance charge per month for accounts over thirty days.

Supervisors Signature

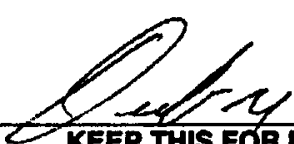

KEEP THIS FOR REFERENCE 


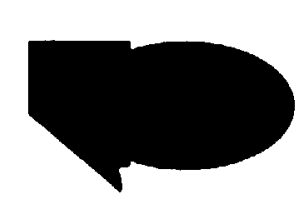

STONE BROTHERS CONSTRUCTION \& DEMOLITION

P.O. Box 3010

.... Tonopah, NV 89049

775-482-2015 - Fax 775-482-2018

END DUMPS - LOWBED • BELLY DUMP • FLATBED

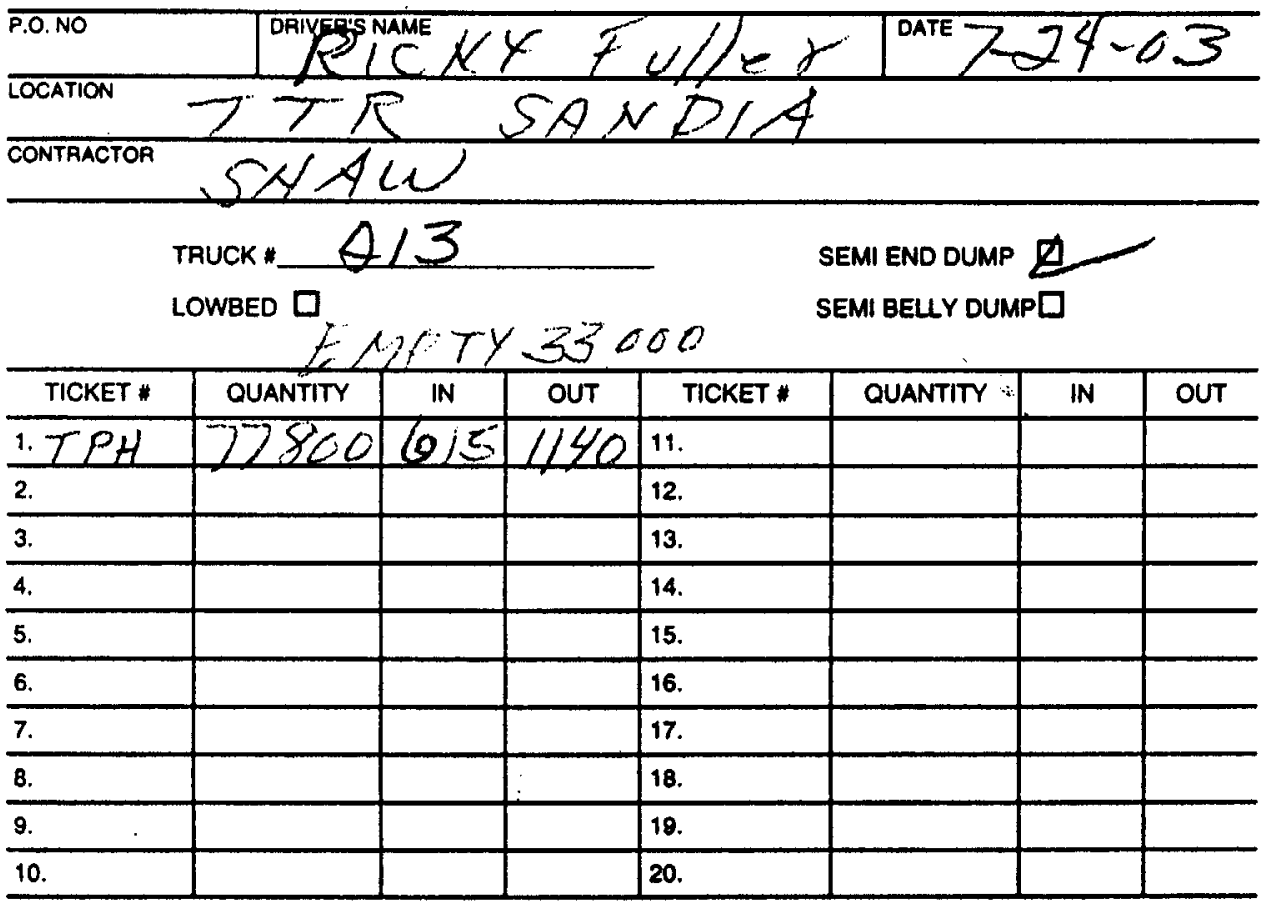

StARt time Le $4 \mathrm{M}$ LUNCH TIME $100-130, A H)$ DOWN TIME STOP TIME $4130 \quad 1$ STAND BY TOTAL TIME 10

REMARKS:

Terms: net due on the 15th of the month following statement date. Past due amounts will be assessed at 1-1/2\% (one and one half percent) finance charge per month for accounts over thinty days.

Supervisors Signature

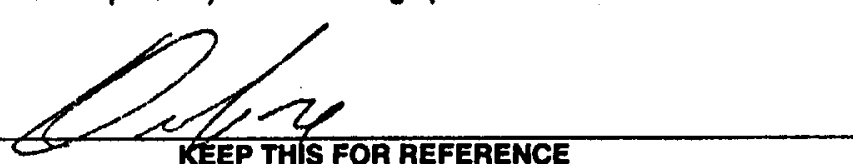

STONE BROTHERS CONSTRUCTION \& DEMOLITION

P.O.'Box 3010

Tonopah, NV 89049

$775-482-2015 \cdot$ Fax 775-482-2018

END DUMPS - LOWBED • BELLY DUMP - FLATBED

DOCNO CONTRACTOA $5 / 20(\mathrm{l})$

TRUCK* $1 / 2$

LOWBED $\square$

24,300

\begin{tabular}{l|l|l|l|l|l|l|l}
\hline TICKET" & OUANTIT & \multicolumn{1}{l|}{ IN } & OUT & TICKET * & QUANTIT & IN & OUT \\
\hline $1 . T P H$ & 20660 & $6^{\prime} / 9$ & & 11. & & & \\
\hline 2. & & & & 12. & & & \\
\hline 3. & & & & 13. & & & \\
\hline 4. & & & & 14. & & & \\
\hline 5. & & & & 15. & & & \\
\hline 6. & & & & 16. & & & \\
\hline 7. & & & & 17. & & & \\
\hline 8. & & & & 18. & & & \\
\hline 9. & & & & 19. & & & \\
\hline 10. & & & & 20. & & & \\
\hline
\end{tabular}

START TIME $O / \Rightarrow$

LUNCH TIME $\angle 2=15-12,45$
DOWNTIME
SEMI END DUMP $\sigma$

SEMI BELY DUMPD

STOP TIME $\&$ 'CSO

STAND BY

TOTAL TIME_/C2
REMARKS:

Terms: net due on the 15th of the month following statement date. Past due amounts will be assessed at 1-1/2\% (one and one half percent) finance charge per month for accounts over thirty days.

Supervisors Signature

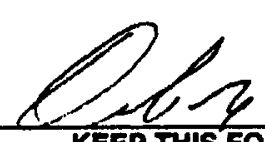




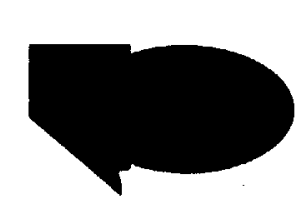

STONE BROTHERS

CONSTRUCTION \& DEMOLITION

P.O.Box 3010

Tonopah, NV 89049

$775-482-2015$ - Fax 775-482-2018

END DUMPS - LOWBED • BELLY DUMP • FLATBED

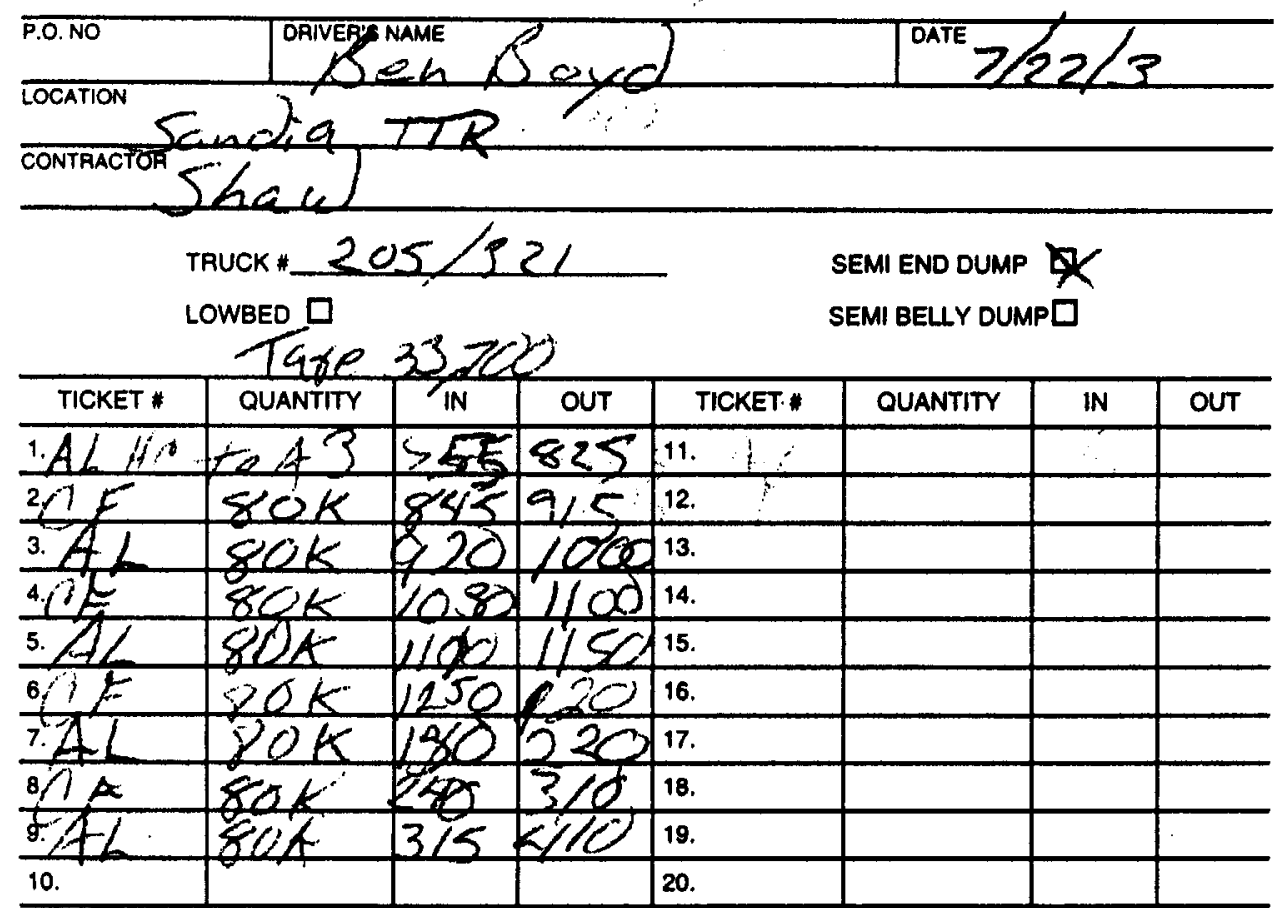

START TIME $\geq 700$ LUNCH TIME $/ 2 / 5$

DOWNTIME

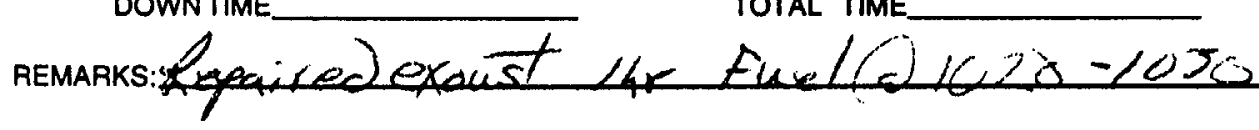

Terms: net due on the 15th of the month following statement date. Past due amounts will be assessed at 1-1/2\% (one and one half percent) finance charge per month for accounts over thirty days.

Supervisors Signature

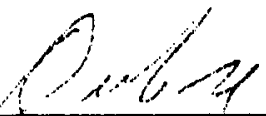

KEEP THIS FOR REFERENCE
STONE BROTHERS

CONSTRUCTION \& DEMOLITION

P.O. Box 3010

Tonopah, NV 89049

775-482-2015 • Fax 775-482-2018

END DUMPS - LOWBED • BELLY DUMP • FLATBED

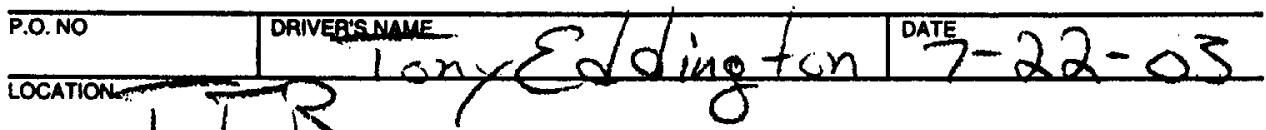

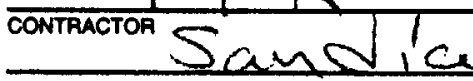

TRUCK" $\angle 12$ SEMI END DUMP E

LOWBED $\square$

24,3007ce SEMI BELLY DUMP

\begin{tabular}{|c|c|c|c|c|c|c|c|}
\hline & & & & & & & \\
\hline TICKET " & QUANTITY & $\mathbf{I N}$ & OUT & TICKET * & QUANTITY & IN & our \\
\hline $1 . A K$ & 6258 & $6: 50$ & 270 & 11.46 & 8528 & 2155 & 32 \\
\hline 2. & 85280 & 2145 & 8125 & 12. & & & \\
\hline 3. & & & 9100 & 13. & & & \\
\hline 4. $C F$ & 8 & & 9735 & 14. & & & \\
\hline 5. $A<$ & & & $10 / 5$ & 15. & & & \\
\hline 6. $S E$ & 5 & 18 & 10,55 & 16. & & & \\
\hline 7. 16 & 81 & 1058 & 12ins & 17. & & & \\
\hline 8. C.E & 85.280 & $1: 15$ & 1045 & 18. & & & \\
\hline 9. 45 & 85 & $1: 49$ & 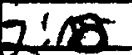 & 19. & & & \\
\hline 10. $C F$ & & $2: 25$ & $2 ! 50$ & 20. & & & \\
\hline
\end{tabular}

START TIME_06(T)

LUNCH TIME $/ 2$ iS -1245

DOWNTIME
STOP TIME $<x i 0$

STAND BY

TOTAL TIME
REMARKS:

Terms: net due on the 15th of the month following statement date. Past due amounts will be assessed at $1-1 / 2 \%$ (one and one half percent) finance charge per month for accounts over thirty days.

Supervisors Signature

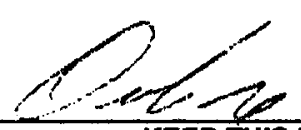
KEEP THIS FOR REFERENCE 


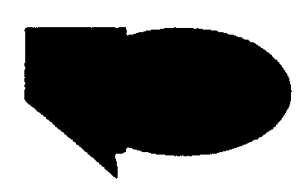

STUNE BROTHERS CONSTRUCTION \& DEMOLITION

P.O. Box 3010

Tonopah, NV 89049

$775-482-2015$ - Fax 775-482-2018

END DUMPS • LOWBED • BELLY DUMP • FLATBED

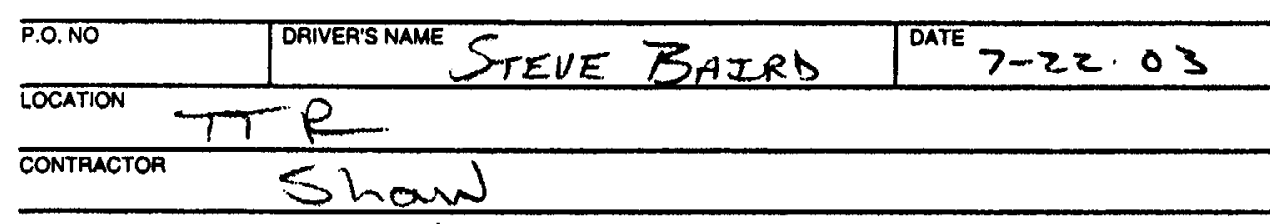

TRUCK: WT ${ }^{\star}$ 2OT SEMI END DUMP $\square$

LOWBED $\square$

SEMI BELYY DUMPD

\begin{tabular}{|c|c|c|c|c|c|c|c|}
\hline TICKET * & QUANTITY & IN & OUT & TICKET * & QUANTITY & IN & OUT \\
\hline 1. $A_{1} S_{1}$ & 1 & 0625 & 0635 & 11. & & & \\
\hline 2. A. L. & 1 & 0726 & 0736 & 12. & & & \\
\hline 3. $\theta, L$ & 1 & 0830 & 8838 & 13. & & & \\
\hline 4. A,L & 1 & 1015 & $10 \geq 4$ & 14. & & & \\
\hline 5. $A, C$ & 1 & 1120 & 1130 & 15. & & & \\
\hline 6. $A, c_{1}$ & 1 & 1305 & 1313 & 16. & $=$ & & \\
\hline 7. $A, C_{1}$ & 1 & 1402 & $14 / 2$ & 17. & & & \\
\hline 8. $A, L_{1}$ & 1 & 1526 & 1532 & 18. & & & \\
\hline 9. & & & & 19. & & & \\
\hline 10. & & & & 20. & & & \\
\hline
\end{tabular}

StART TIME Ob:00 LUNCH TIME $12: 00-12: 30$ DOWNTIME_Z REMARKS

Terms: net due on the 15th of the month following statement date. Past due amounts will be assessed at 1-1/2\% (one and one half percent) finance charge per month for accounts over thirty days.

Supervisors Signature

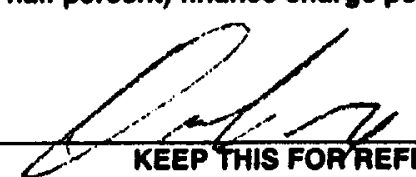

STOP TIME $16: 00$

STANDBY $\theta$.

TOTAL TIME $9 \%$
SIUNE BRUTHERS

CONSTRUCTION \& DEMOLITION

P.O. Box 3010

Tonopah, NV 89049

775-482-2015 - Fax 775-482-2018

END DUMPS ・ LOWBED ・ BELLY DUMP ・ FLATBED

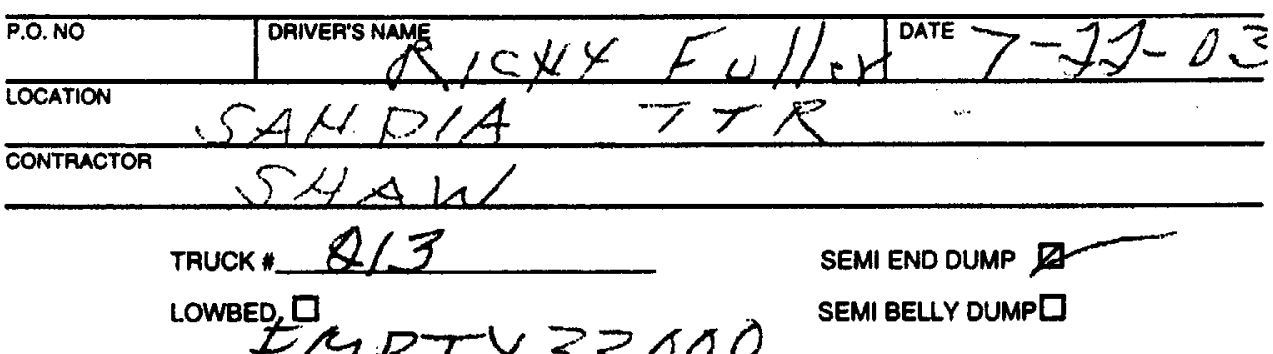

\begin{tabular}{|c|c|c|c|c|c|c|c|}
\hline TICKET * & QUANTITY & IN & OUT & TICKET * & QUANTITY & IN & OUT \\
\hline 196,500 & $4 L$ & $\operatorname{les} 8$ & 215 & 11. & & & \\
\hline 2.03500 & $E E$ & & 860 & 12. & & & \\
\hline 323500 & $S F$ & $8=$ & 858 & 13. & & & \\
\hline 4.93500 & $C F$ & 272 & 1000 & 14. & & & \\
\hline 5.97500 & $C E$ & 1032 & 1102 & 15. & & & \\
\hline 6.91 .500 & $A L$ & 11 & 455 & 16. & & & \\
\hline $7.535 \mathrm{co}$ & SF & 223 & 1254 & 17. & & & \\
\hline 8.85000 & $6 \%$ & 120 & 150 & 18. & & & \\
\hline 9.16500 & 46 & & 940 & 19. & & & \\
\hline 10.96500 & $A^{2}$ & 3 & & 20. & & & \\
\hline
\end{tabular}

START TIME_ lo 00

LUNCH TIME $12 / 0-1230$

DOWNTIME
STOP TIME__ 1630

STAND BY

total time 10 líno.
REMARKS:

Terms: net due on the 15th of the month following statement date. Past due amounts will be assessed at $1.1 / 2 \%$ (one and one half percent) finance charge per month for accounts over thirty days.

Supervisors Signature

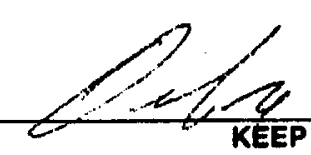


P.O. Box 3010

Tonopah, NV 89049

$775-482-2015 \cdot$ Fax $775-482-2018$

\section{END DUMPS - LOWBED • BELLY DUMP - FLATBED}

\begin{tabular}{|c|c|c|c|c|c|c|c|}
\hline$\overline{\mathrm{O} . \mathrm{NO}}$ & \multicolumn{2}{|c|}{ DRIVEDIGAG } & $E \alpha$ & $\operatorname{lin} x$ & \multicolumn{3}{|c|}{${ }^{\text {DATE }} 7-21-03$} \\
\hline \multicolumn{8}{|c|}{ CONTRACTOR Sandia } \\
\hline \multicolumn{4}{|c|}{ TRUCK: 112} & \multirow{2}{*}{\multicolumn{4}{|c|}{$\begin{array}{l}\text { SEMI END DUMP } \\
\text { SEMI BEUY DUMPD }\end{array}$}} \\
\hline \multicolumn{4}{|c|}{$\begin{array}{l}\text { LOWBED } \\
2(, 3 x)\end{array}$} & & & & \\
\hline TICKET * & QUANTITY & IN & OUT & TICKET * & QUANTITY & IN & OUT \\
\hline 1.01 & 85 & $1: 50$ & $7: 45$ & 11. $A b$ & 85280 & 258 & 328 \\
\hline $2 . C E$ & 85 & 7.55 & $8: 25$ & 12. & & & \\
\hline 3. $9 \mathrm{~h}$ & 85280 & $8: 27$ & $9: 12$ & 13. & & & \\
\hline 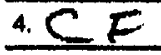 & 85.280 & 7.20 & $9: 45$ & 14. & & & \\
\hline 5. $A L$ & 85,280 & $9: 50$ & 1050 & 15. & & & \\
\hline 6. CF & 85.280 & 1040 & 1105 & 16. & & & \\
\hline 7. $A 6$ & 8551280 & 4120 & 1155 & 17. & & & \\
\hline 8. CF & 85028 & 1.15 & $1: 40$ & 18. & & & \\
\hline 9. $A L$ & 85.280 & & $2: 25$ & 19. & & & \\
\hline 10. C.F & 85.780 & $2: 33$ & 2.55 & 20. & & & \\
\hline
\end{tabular}

START TIME 0600 LUNCH TIMELLi15-12:45 DOWNTIME
STOP TIME $\not$ 'OC)

STAND BY

TOTAL TIME $97 / 2$
REMARKS:

Terms: net due on the 15th of the month following statement date. Past due amounts will be assessod at $1-1 / 2 \%$ (one and one half percent) finance charge per month for accounts over thirty days.

Supervisors Signature

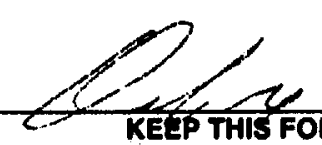

SIUNE BHUIMEKS CONSTRUCTION \& DEMOLITION

P.O. Box 3010

Tonopah, NV 89049

$775-482-2015 \cdot$ Fax $775-482-2018$

END DUMPS • LOWBED • BELLY DUMP • FLATBED

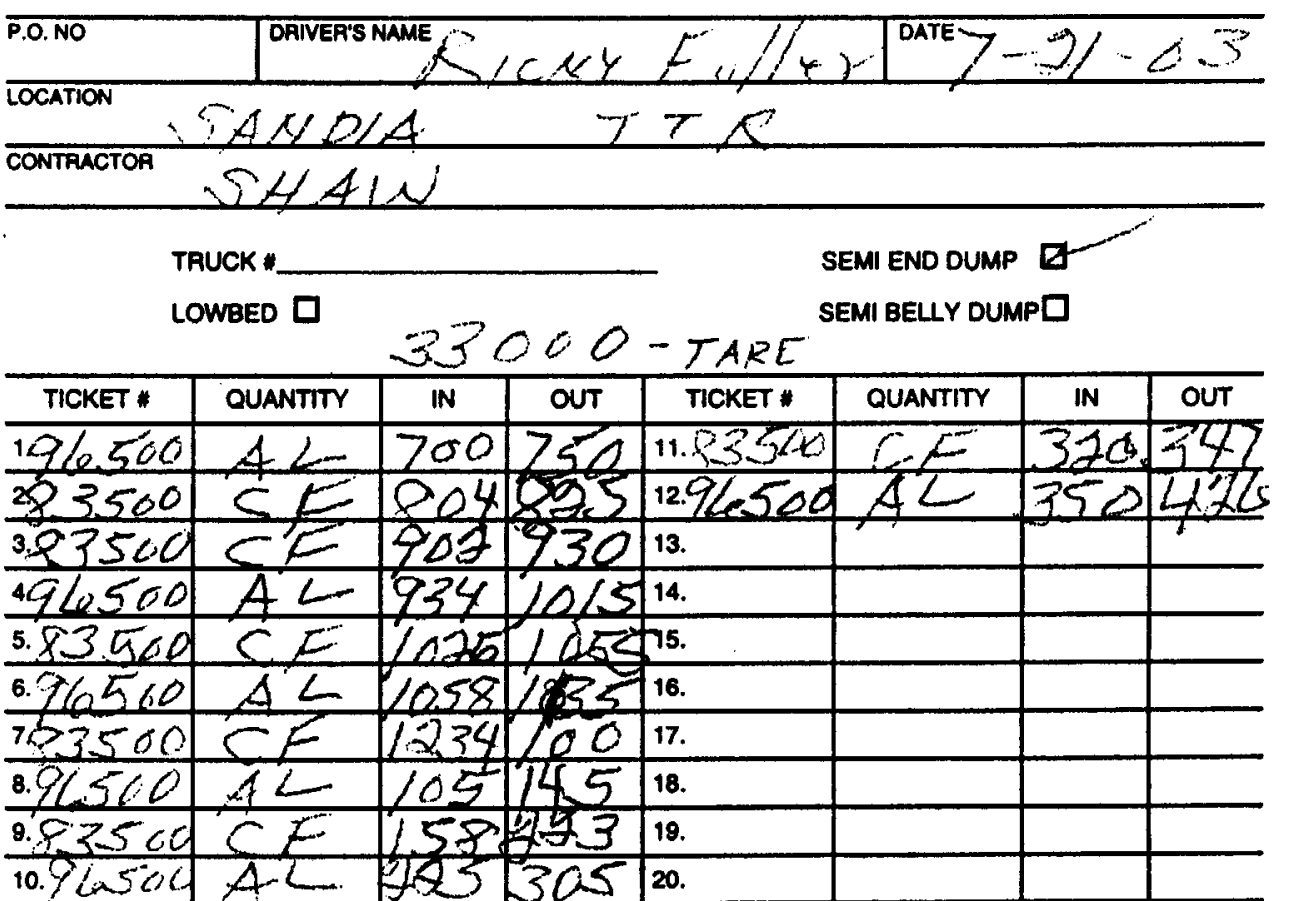

START TIME_L_ $\triangle M$ LUNCH TIME $1150-17270$ DOWNTIME stop time 4'36) STAND BY TOTAL TIME $(\infty$

REMARKS:

Terms: net due on the 15th of the month following statement date. Past due amounts will be assessed at $1-1 / 2 \%$ (one and one half percent) finance-oharge per month for accounts over thirty days.

Supervisors Signature

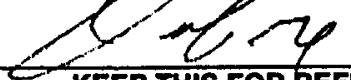

KEEP THIS FOR REFERENCE 


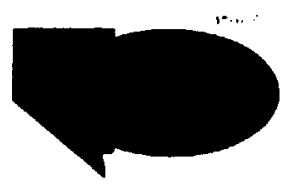

SIUNE BROTHERS CONSTRUCTION \& DEMOLITION

P.O.BOX 3010

Tonopah, NV 89049

in

775-482-2015 • Fax 775-482-2018

END DUMPS • LOWBED - BELLY DUMP • FLATBED

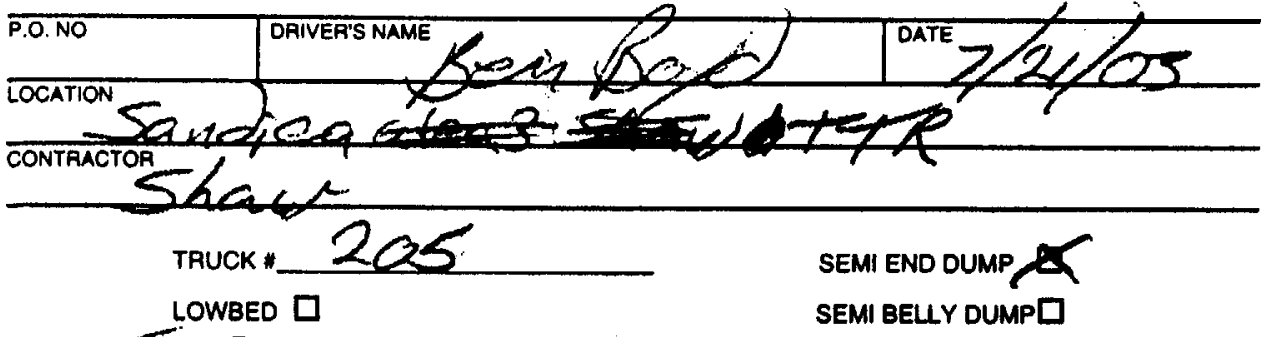

Ta6 3,750

\begin{tabular}{|c|c|c|c|c|c|c|c|}
\hline TICKET * & QUÁNTITY & IN & OUT & TICKET " & QUANTITY & IN & OUT \\
\hline 1. $A L$ & 27420 & 700 & 6 & 11. & & & \\
\hline CF & 80 & 8 & 33 & 12. & & & \\
\hline $3.2 E$ & $x \in k$ & $\angle e 0$ & 120 & 13. & & & \\
\hline 4212 & $x^{2}, 1 x=$ & 5 & 2 & 14. & & & \\
\hline 5. 4 & Fok & $2 \pi 5$ & 245 & 15. & & & \\
\hline 6.115 & \&OK & 305 & 33 & 16. & & & \\
\hline $7 A^{\prime} L$ & 536 & 38 & 412 & 17. & & & \\
\hline 8. & & & & 18. & & & \\
\hline 9. & & & & 19. & & & \\
\hline 10. & & & & 20. & & & \\
\hline
\end{tabular}

START TMEE 600

STOP TIME $4(2 /)$

LUNCH TIME

STAND BY

DOWN TIME

TOTAL TIME

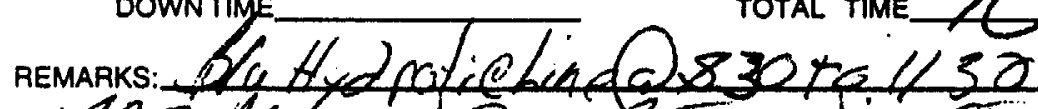

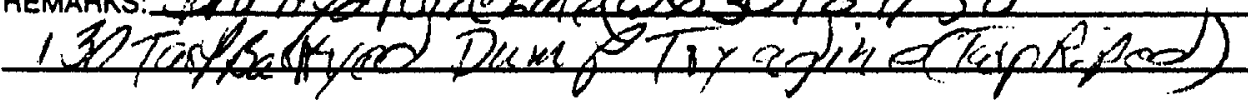

Terms: net due on the 15 th of the month following statement date. Past due amounts will be assessed at 1-1/2\% (one and one half percent) finance charge per month for accounts over thirty days.

Supenisors Signature

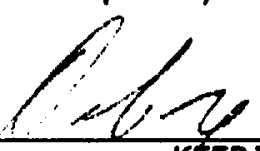

Divive onv inchs

- Tonopah, NV 89049

775-482-2015 • Fax 775-482-2018

END DUMPS • LOWBED • BELLY DUMP • FLATBED

\begin{tabular}{|c|c|c|}
\hline O.NO & DAIVER'S NAME STEVE BATRD & DATE $7-2$ \\
\hline 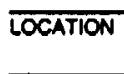 & $R-A . L . /$ Cand & Roads \\
\hline
\end{tabular}

CONTRACTOR

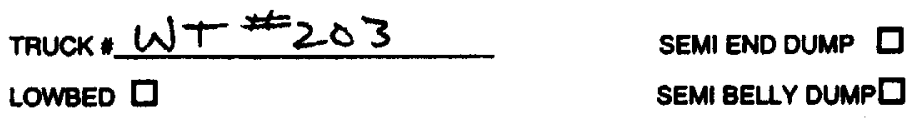

\begin{tabular}{|c|c|c|c|c|c|c|c|}
\hline TICKET: & OUANTITY & IN & OUT & TICKET * & QUANTITY & IN & OUT \\
\hline 1. $A_{1} L_{1}$ & 1 & 1727 & 0740 & 11. & & & \\
\hline 2. $A, L$ & 1 & 0845 & 0854 & 12. & & & \\
\hline 3. $A_{1}<1$ & 1 & $10<5$ & 1035 & 13. & & & \\
\hline 4. A. L & 1 & 1145 & 164 & 14. & & & \\
\hline 5. $A-L$ & 1 & 1229 & 1238 & 15. & & & \\
\hline 6. A,L & 1 & 1538 & 1349 & 16. & & & \\
\hline 7. $A_{1}<1$ & 1 & 1435 & 1445 & 17. & & & \\
\hline 8. & & & & 18. & & & \\
\hline 8. & & & & 19. & & & \\
\hline 10. & & & & 20. & & & \\
\hline
\end{tabular}

START TIME 06:00 LUNCH TIME /2:00 - 12:30 DOWNTIME 2
STOP TIME $16: 00$

STANDBY

REMARKS:

Terms: net due on the 15th of the month following statement date. Past due amounts will be assessed at 1-1/2\% (one and one half percent) finance charge per month for accounts over thirty daye.

Supervisors Signature

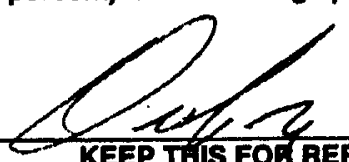




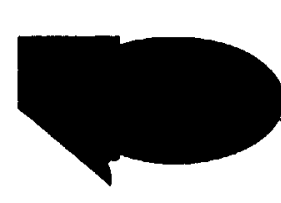

STONE BROTHERS

CONSTRUCTION \& DEMOLITION

P.O.BOX 3010

Tonopah, NV 89049

$775-482-2015 \cdot$ Fax $775,482-2018$

END DUMPS - LOWBED - BELLY DUMP • FLATBED

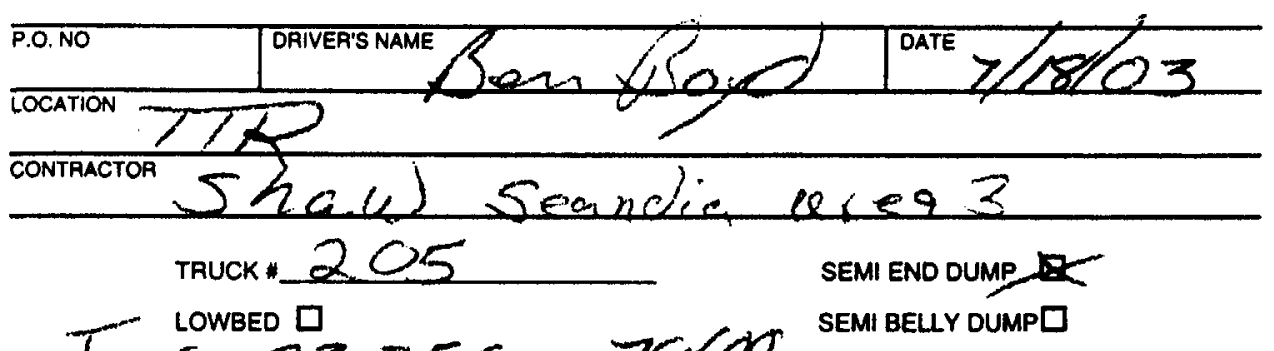

\begin{tabular}{|c|c|c|c|}
\hline TICKET " & QUANTITY & IN & OUT \\
\hline $1 . A C$ & $F_{a 1}$ & 635 & $32 d$ \\
\hline $2.0 \mathrm{~F}$ & $1 \%$ & 740 & 800 \\
\hline 3. 41 & 16 & $8 / 0$ & 850 \\
\hline 4. $\lambda k$ & 18 & 915 & 540 \\
\hline 5. AL & is & 645 & 1025 \\
\hline \multicolumn{4}{|l|}{6.} \\
\hline \multicolumn{4}{|l|}{7.} \\
\hline \multicolumn{4}{|l|}{8.} \\
\hline 9. & & L & \\
\hline 10. & & & \\
\hline
\end{tabular}

LUNCH TIME

DOWNTIME

REMARKS: 440630
StARt TIME 6 AM

\begin{tabular}{|l|l|l|l}
\hline TICKET * & QUANTITY & IN & OUT \\
\hline 11. & & & \\
\hline 12. & & & \\
\hline 13. & & & \\
\hline 14. & & & \\
\hline 15. & & & \\
\hline 16. & & & \\
\hline 17. & & & \\
\hline 18. & & & \\
\hline 18. & & & \\
\hline 20. & & & \\
\hline
\end{tabular}

1

STOP TIME

TOTAL, TIME

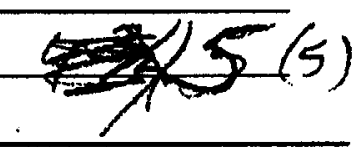

Terms: net due on the 15 th of the month following statement date. Past due amounte will be assessed at $1.1 / 2 \%$ (one and one half percent) finance charge per month for accounts over thirty days.

STONE BROTHERS

CONSTRUCTION \& DEMOLITION

P.O. Box 3010

Tonopah, NV 89049

$775-482-2015$ - Fax 775-482-2018

END DUMPS - LOWBED • BELLY DUMP • FLATBED

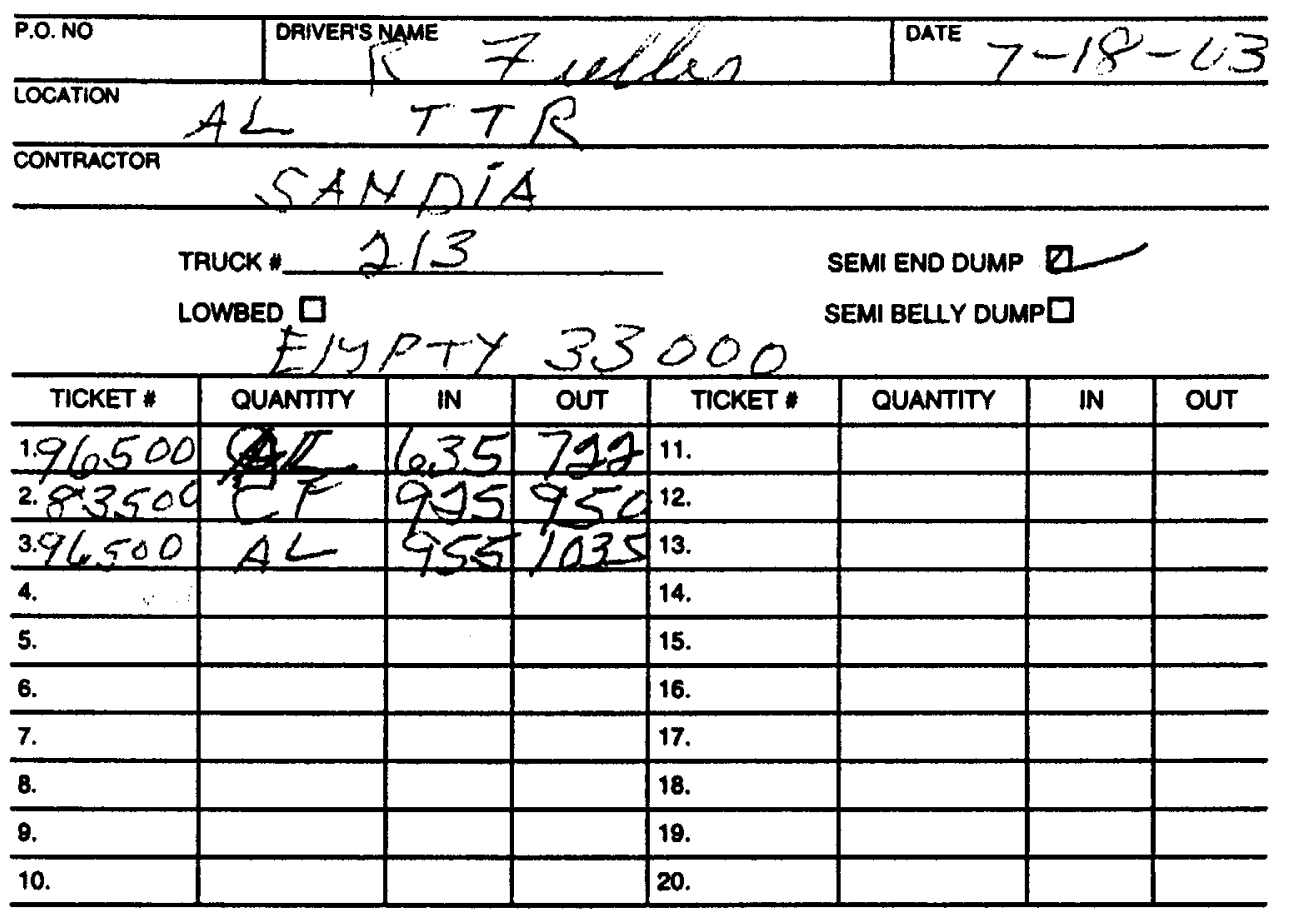

START TIME_LCAM

LUNCH TIME

DOWNTIME $722-912$ REMARKS: BROPKEX MADKCLIC HOSe

STOP TIME 1100 STAND BY

TOTAL TIME $\neg$

Terms: net due on the 15th of the month following statement date. Past due amounts will be assessed at 1-1/2\% (one and one halt percent) finance charge per month for accounts over thirty days.

Supervisors Signature 


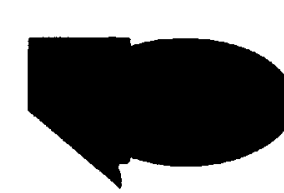

\section{STONE BROTHERS}

\section{CONSTRUCTION \& DEMOLITION}

P.O. Box 3010

Tonopah, NV 89049

775-482-2015 • Fax 775-482-2018

END DUMPS - LOWBED - BELLY DUMP - FLATBED

\begin{tabular}{l|l|l}
\hline P.O.NO & DRIVER'S NAME STEVE BAIRD & DATE \\
\hline LOCATION & ST-O3 \\
\hline CONTAACTOR
\end{tabular}

\begin{tabular}{|c|c|c|c|c|c|c|c|}
\hline \multicolumn{4}{|c|}{$\begin{array}{l}\text { TAUCK" } W T \# 203 \\
\text { LOWBED } \square\end{array}$} & \multicolumn{4}{|c|}{$\begin{array}{l}\text { SEMI END DUMP } \square \\
\text { SEMI BELYY DUMPD }\end{array}$} \\
\hline TICKET " & OUANTITY & IN & OUT & TICKET * & QUANTITY & IN & OUT \\
\hline 1. & & & & 11. & & & \\
\hline 2. & & & & 12. & & & \\
\hline 3. & & & & 13. & & & \\
\hline 4. & & & & 14. & & & \\
\hline 5. & & & & 15. & & & \\
\hline 6. & & & & 16. & & & \\
\hline 7. & & & & 17. & & & \\
\hline 8. & & & & 18. & & & \\
\hline 9. & & & & 19. & & & \\
\hline 10. & & & & 20. & & & \\
\hline
\end{tabular}

START TIME O6:00

LUNCH TIME

DOWNTIME Z,O hrs
StOP TIME_ $08: 00$

STAND BY

TOTAL TIME $Z, 0$

REMARKS:

Terms: net due on the 15th of the month following statement date. Past due amounts will be assessed at $1-1 / 2 \%$ (one and one half percent) finance charge per month for accounts over thirty days.

Supervisors Signature

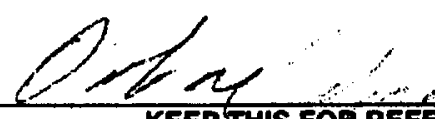

KEEPTHIS FOA REFERENCE

STONE BROTHERS

CONSTRUCTION \& DEMOLITION

P.O. Box 3010

Tonopah, NV 89049

775-482-2015 • Fax 775-482-2018

END DUMPS • LOWBED • BELLY DUMP • FLATBED

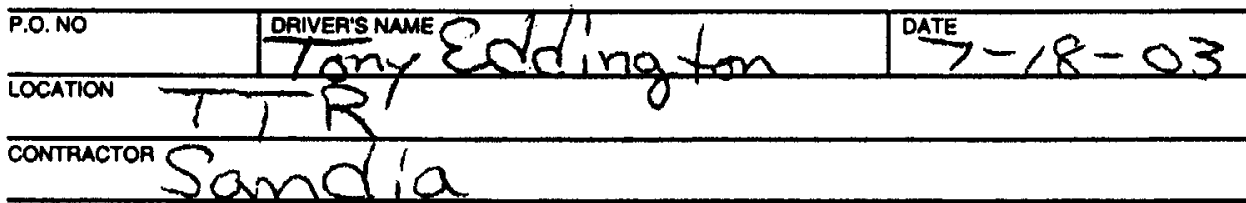

\begin{tabular}{|c|c|c|c|c|c|c|c|}
\hline \multicolumn{4}{|c|}{ TRUCK" $\angle \perp Q$} & \multirow{2}{*}{\multicolumn{4}{|c|}{$\begin{array}{l}\text { SEMI END DUMP } \\
\text { SEMI BELIY DUMP }\end{array}$}} \\
\hline & OWBED & 07 & $\omega$ & & & & \\
\hline TICKET" & QUANTITY & IN & OUT & TICKET * & QUANTITY & IN & OUT \\
\hline $14 L$ & 89.640 & $6: 25$ & $7: 8$ & 11. & & & \\
\hline $2 . \Gamma$ & 78,750 & 7,30 & & 12. & & & \\
\hline 3. $1 \mathrm{AL}$ & 85,680 & 7502 & 8137 & 13. & & & \\
\hline 4. $C F$ & 78.780 & $8^{\prime}<9$ & g:20 & 14. & & & \\
\hline 5. $A L$ & 8964 & $9: 13$ & $9: 57$ & 15. & & & \\
\hline 6. & & & & 16. & & & \\
\hline 7. & & & & 17. & & & \\
\hline 8. & & & & 18. & & & \\
\hline 9. & & & & 19. & & & \\
\hline 10. & & & & 20. & & & \\
\hline
\end{tabular}

START TIME_0600

LUNCH TIME

DOWNTIME
STOP TIME / LiOO

STANDBY

TOTAL TIME $S$
REMARKS

Terms: net due on the 15th of the month following statement date. Past due amounts will be assessed at 1-1/2\% (one and one half percent) finance charge per month for accounts over thirty days.

Supervisors Signature

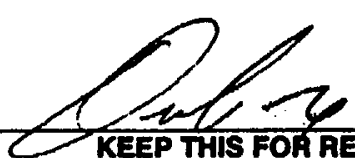




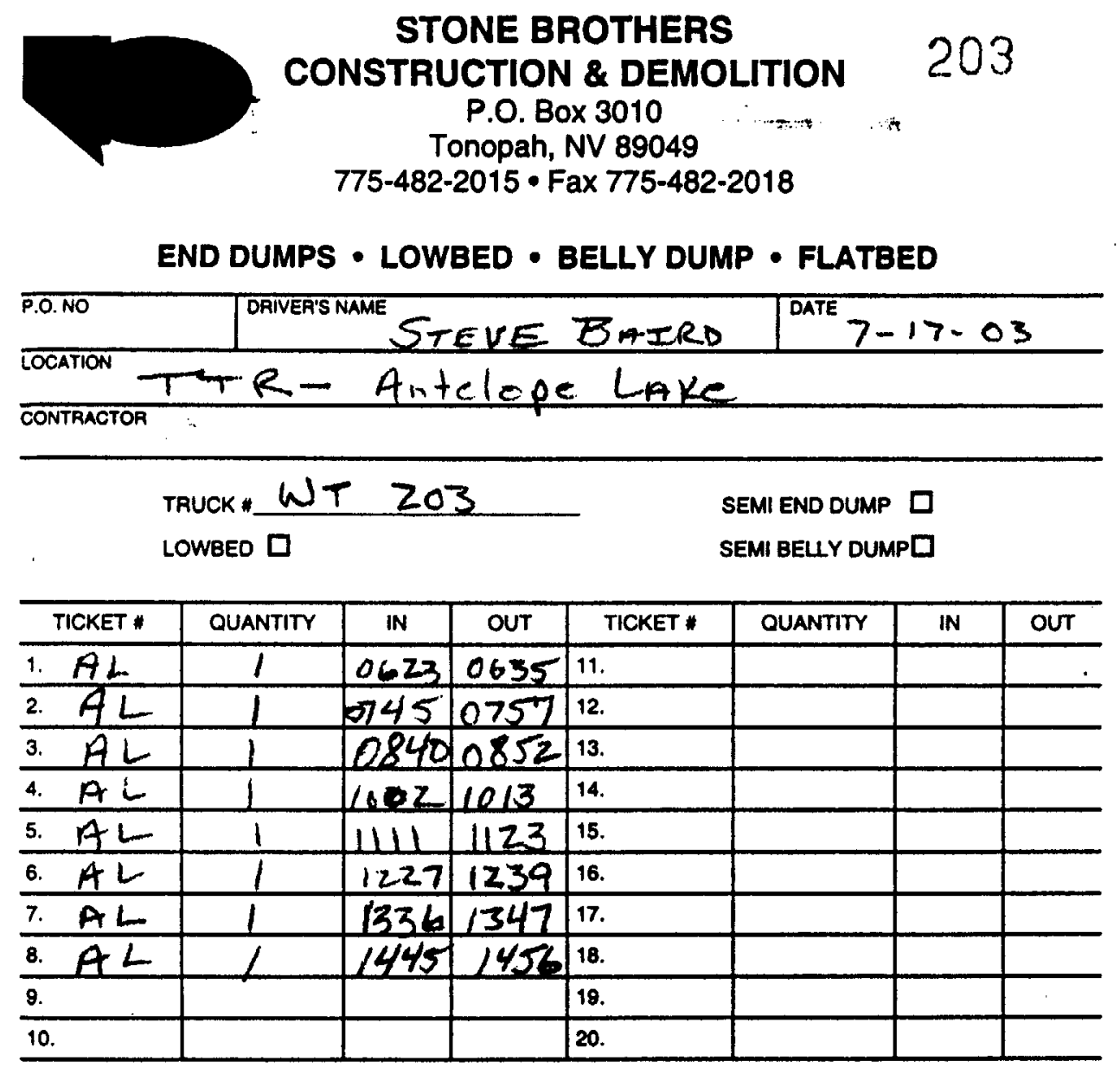

StART tIME $0600 \quad$ StOP TIME 4:00

LUNCH TIME $\|$ II:30-12:00

DOWNTIME $=1.5$

STANDBY $\theta$

TOTAL TIME $91 / 2$

REMARKS: In $*$ Out times are at the well filling up.

Terms: net due on the 15th of the month following statement date. Past due amounts will be assessed at $1-1 / 2 \%$ (one and one half percent) finance charge per month for accounts over thirty days.

Supervisors Signature

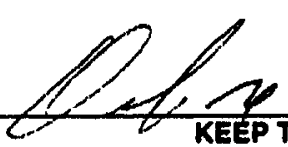

STONE BROTHERS

CONSTRUCTION \& DEMOLITION

P.O. Box 3010

Tonopah, NV 89049

$775-482-2015 \cdot F a x$ 775-482-2018

END DUMPS • LOWBED • BELLY DUMP • FLATBED

\begin{tabular}{|c|c|c|c|c|c|c|c|}
\hline \multicolumn{5}{|c|}{$\begin{array}{l}\text { DAIVEA'S NAME } \\
\text { Toxyt }\end{array}$} & \multicolumn{3}{|c|}{ DATE $7-17-03$} \\
\hline \multicolumn{8}{|c|}{ 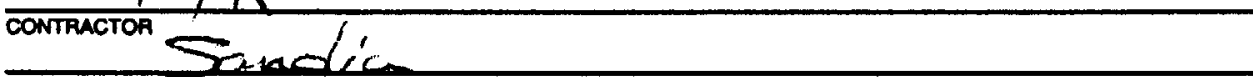 } \\
\hline & $\begin{array}{l}\text { RUCK } \frac{1}{1 /} \\
\text { OWBED } \square \\
24,680\end{array}$ & $-T_{t}$ & ARE W & $6 H T$ & $\begin{array}{l}\text { SEMI END DUMP } \\
\text { SEMI BELYY DUM }\end{array}$ & ס & \\
\hline TICKET " & QUANTITY & $\mathbb{N}$ & OUT & TICKET " & QUANTIT & $\overline{I N}$ & OUT \\
\hline 1. $A L$ & 86.140 & $6: 40$ & $2: 40$ & 11. AL & 89,640 & 250 & 913 \\
\hline 2. $C E$ & 28780 & $7: 50$ & $\sin 3$ & 12. & & & - \\
\hline 3. AL & 86 & $8: 15$ & $8: 54$ & 13. & & & \\
\hline 4. & 78 & $9 \times 9$ & $9 / 31$ & 14. & & & \\
\hline 5. & 89 & 213 & 10,35 & 15. & & & \\
\hline$E$ & 28 & 1445 & 413 & 16. & & & \\
\hline 7. $4 \%$ & 899640 & 415 & & 17. & & & \\
\hline 8. CE & 28780 & 125 & 119 & 18. & & & \\
\hline 8. $A L$ & 8969 & 121 & & 19. & & & \\
\hline 10. $C F$ & 78,780 & 2,201 & $2: 55$ & 20. & & & \\
\hline
\end{tabular}

START TIME_O6OQ

STOP TIME $\angle \not, i C O$

LUNCH TIME $\angle 2: 15-12: 45$

DOWNTIME

STANDBY

TOTAL TIME 372

REMARKS

Terms: net due on the 15th of the month following statement date. Past due amounts will be assesed at 1-1/2\% (one and one half percent) finance charge per month for accounts over thirty days.

Supenisors Signature KEEP THS FOR REFERENCE 


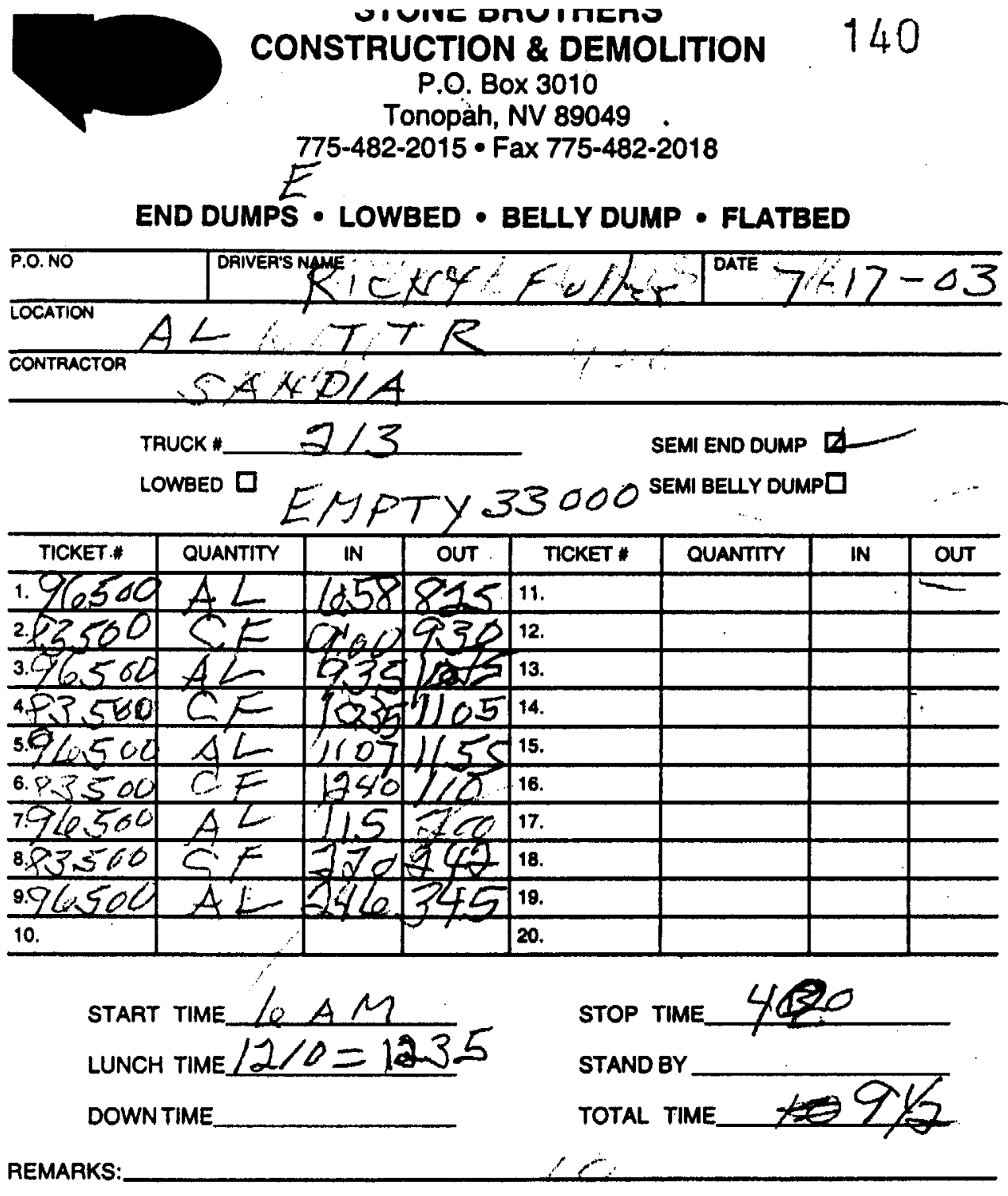

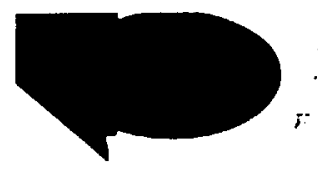

CONSTRUCTION \& DEMOLITION

172

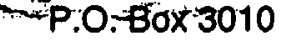

Tonopah, NV 89049

$775-482-2015 \cdot \mathrm{Fax} 775-482-2018$

END DUMPS - LOWED - BELLY DUMP - FLATBED

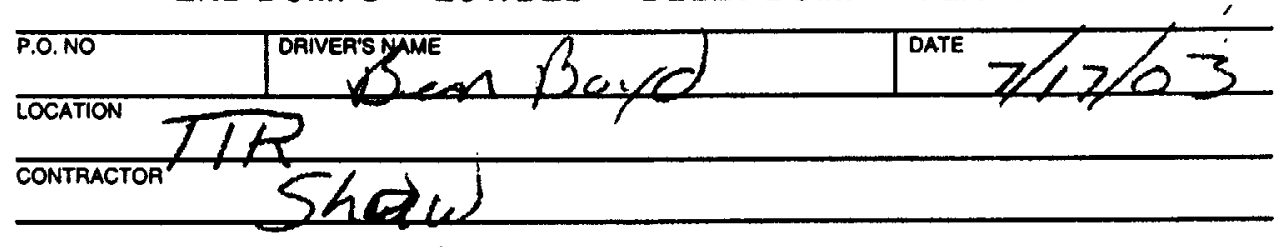

тRUск 2025

SEMI END DUMP DX

LOWEED D Ta 600 Ta 33750 SEMI BELLY DUMP D

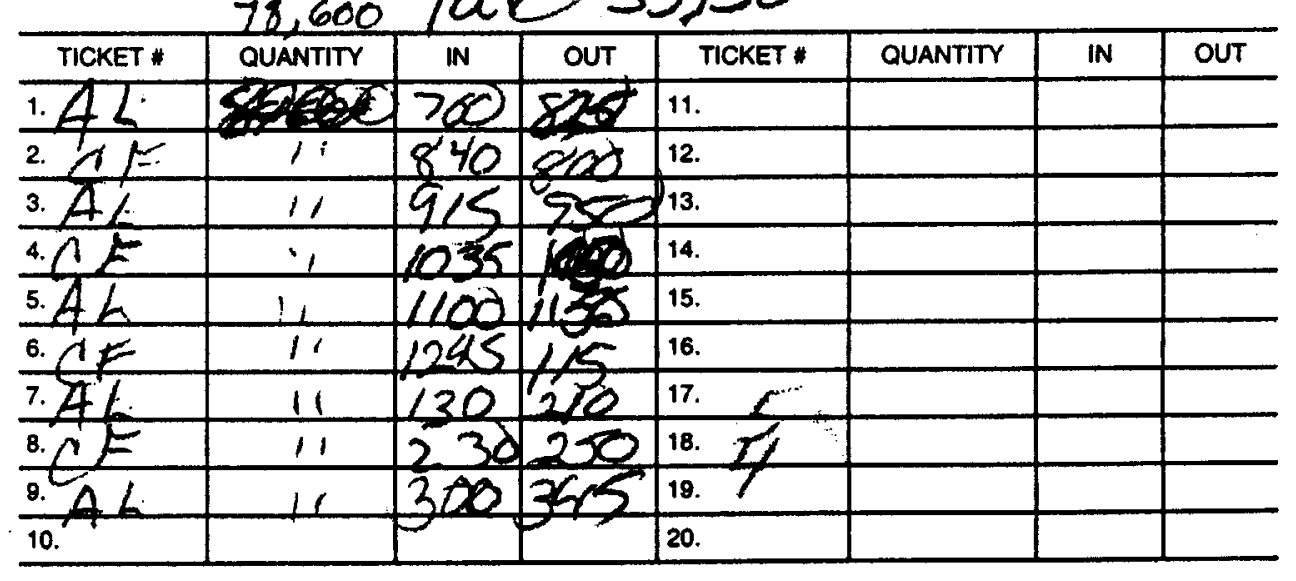

START TIME 6 aMA

LUNCH TIME $12 / 5$

STOP TIME $Y$ PM

DOWN TIME

STANDBY

TOTAL TIME $\sum \frac{1}{2}$

REMARKS Fig to Tola 062

whys 2401800 950heshivadsthetho

Terms: net due on the 15th of the month following statement date. Past due amounts will be assessed at 1-1/2\% (one and one half percent) finance charge per month for accounts over thirty days.

Supervisors Signature

Terms: net due on the 15th of the month following statement date. Past due amounts will be assessed at 1-1/2\% (one and one half percent) finance charge per month for accounts over thirty days.

Supervisors Signature

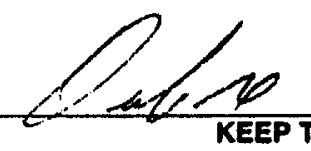

THIS FOR REFERENCE 


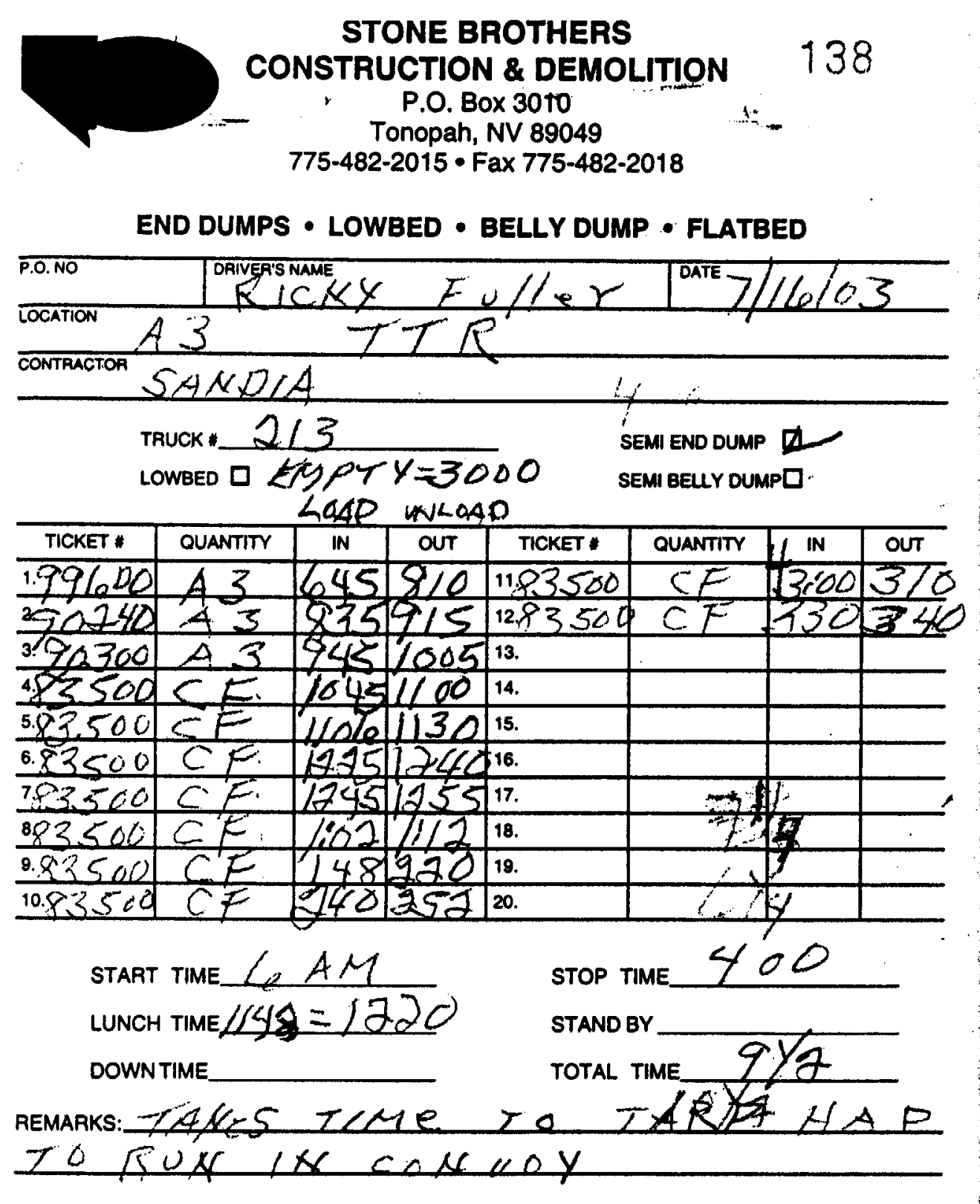

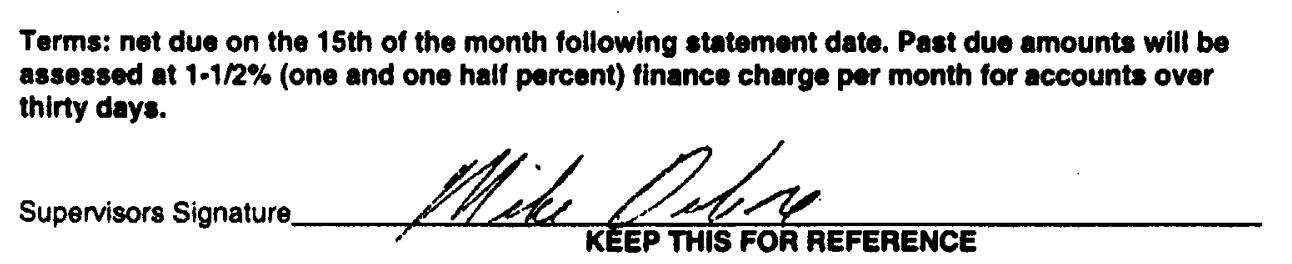

STONE BROTHERS CONSTRUCTION \& DEMOLITION P.O. Box $\overline{3010}$

Tonopah, NV 89049

775-482-2015 • Fax 775-482-2018

\begin{tabular}{|c|c|c|c|c|c|c|c|}
\hline \multicolumn{8}{|c|}{ END DUMPS • LOWBED • BELLY DUMP • FLATBED } \\
\hline \multicolumn{8}{|c|}{ LOCATION } \\
\hline \multicolumn{4}{|c|}{ TRUCK: 205} & \multicolumn{4}{|c|}{$\begin{array}{l}\text { SEMI END DUMP Y } \\
\text { SEMI BELLY DUMPD }\end{array}$} \\
\hline TICKET * & QUANTITY & IŃ & OUT & TICKET * & QUANTITY & IN & OUT \\
\hline 1. 43 & 2765 & 725 & 15 & 11. & & & \\
\hline 2. 13 & 87220 & 620 & 24 & 12. & & & \\
\hline 3. 43 & $80 k t$ & 935 & $6<5$ & 13. & & & \\
\hline 4. $A 3$ & $1 \%$ & 1032 & 40 & 14. & & & \\
\hline 5. 6 & $763 x$ & $11 y$ & & 15. & & & \\
\hline 6. Ct & $804 k$ & 1252 & 65 & 16. & & & \\
\hline 7. 1. & $\gamma 0+5$ & 15 & 125 & 17. & & & \\
\hline 8. 14 & $6 y k$ & 240 & 225 & 18. & & & \\
\hline 9. 12 & $80 t$ & 240 & & 19. & & & \\
\hline 10. $E$ & $6)+1$ & $3 / 0$ & 33 & 20. & & & \\
\hline
\end{tabular}

START TIME ' 4 LUNCH TIME $1210-1240$ DOWNTIME

REMARKG a
STOP TIME $4 / 2$ P STAND BY TOTAL TIME $431 / 2 \%$ Tearwate 33,750 ;

Terms: net due on the 15 th of the month following statement date. Past due amounts will be assessed at $1-1 / 2 \%$ (one and one half percent) finance charge per month for accounts over thirty days.

Supervisors Signature

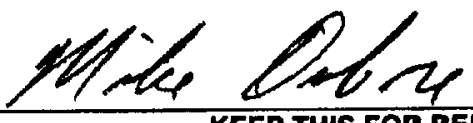
KEEP THIS FOA REFERENCE 
SIUNE EMUIMEKS

CONSTRUCTIOALREAMOLIION

P.O. Box 3010

Tonopah, NV 89049

$775-482-2015$ - Fax 775-482-2018

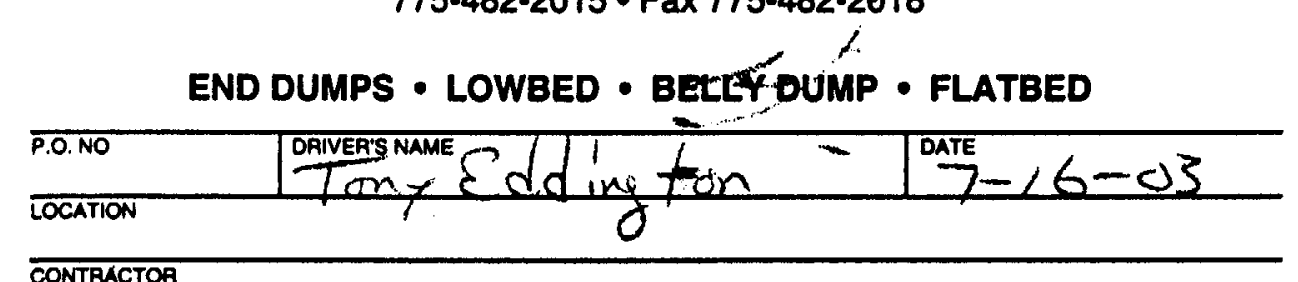

CONTRKCTOP

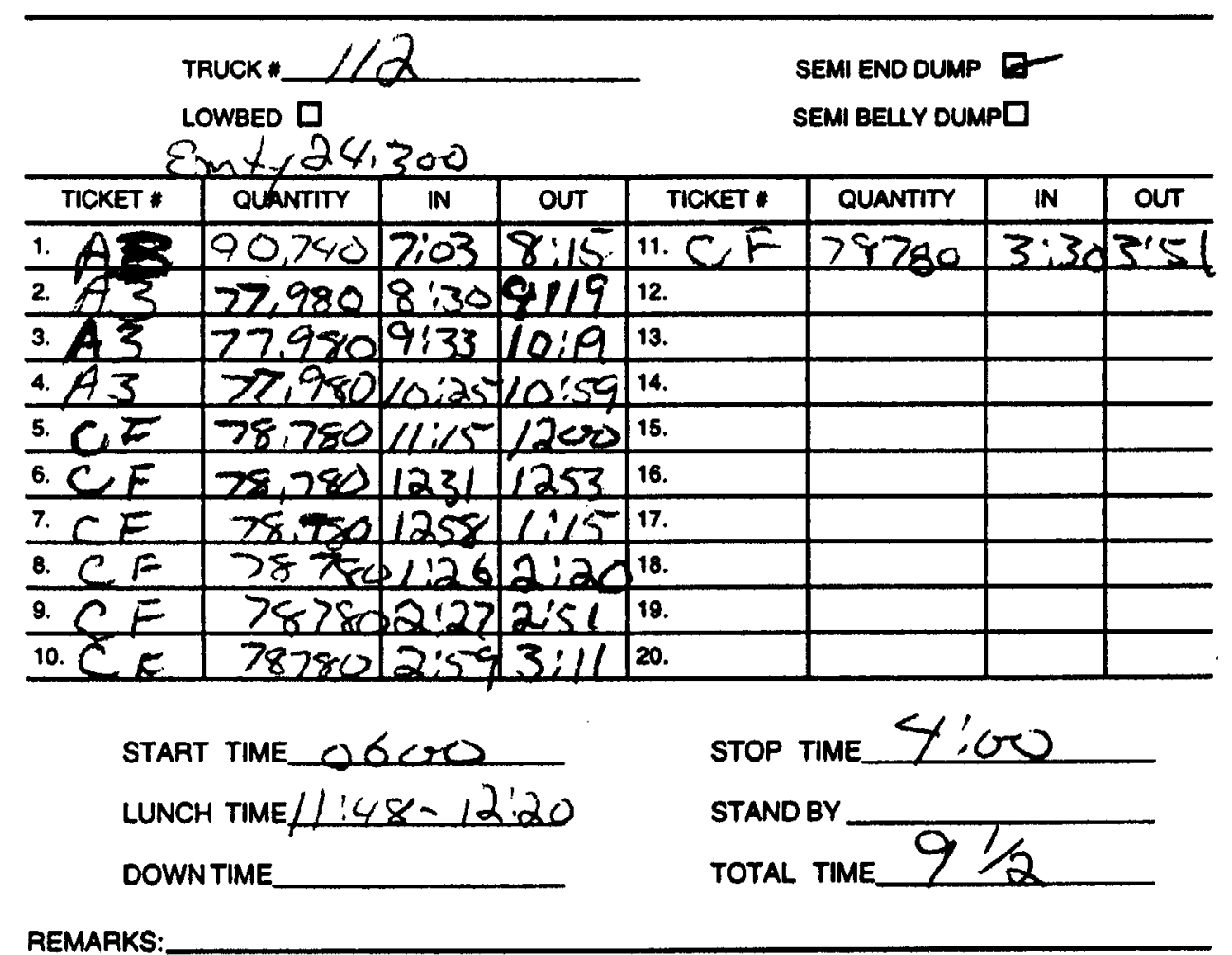

Terms: net due on the 15th of the month following statement date. Past due amounts will be assessed at $1-1 / 2 \%$ (one and one half percent) finance charge per month for accounts over thirty days.

Supervisors Signature

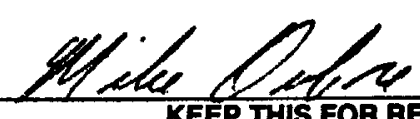

SIUNE BHU I MERS CONSTRUCTION \& DEMOLITION 202 R.O. Box 3010

Tonopah, NV 89049

$775-482-2015 \cdot$ Fax 775-482-2018

END DUMPS - LOWBED - BELLY DUMP ・ FLATBED

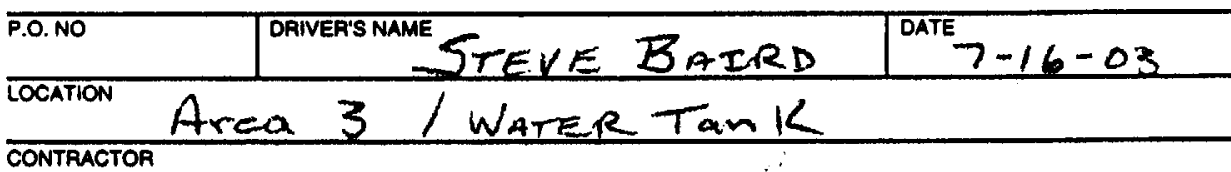

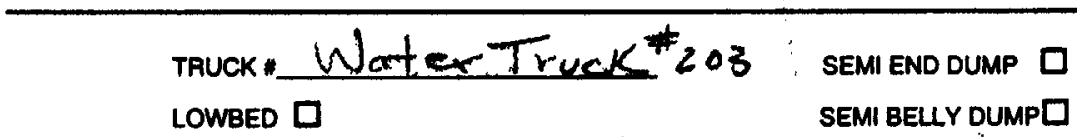

\begin{tabular}{|c|c|c|c|c|c|c|c|}
\hline TICKET * & QUANTITY & IN & OUT & TICKET * & QUANTITY & IN & OUT \\
\hline 1. $A-3$ & 1 & 064.5 & 0700 & 11. & & & \\
\hline 2. $A-3$ & 1 & 0847 & 0903 & 12. & & & \\
\hline 3. $A-3$ & 1 & $101 \mathrm{k}$ & 1027 & 13. & & & \\
\hline 4. $A-3$ & 1 & 1210 & 1223 & 14. & & & \\
\hline 5. $A-3$ & $L$ & 1325 & 1237 & 15. & & & \\
\hline 6. $A-3$ & 1 & 1447 & 1500 & 16. & & & \\
\hline 7. & & & & 17. & & & \\
\hline 8. & & & & 18. & & . & \\
\hline 9. & & & & 19. & & & \\
\hline 10. & & & & 20. & & & \\
\hline
\end{tabular}

START TIME $06: 00$

LUNCH TIME $11: 40-12: 10$

DOWNTIME $\Theta$

STOP TIME $\angle 6, \theta 0$

STAND BY

$\theta$

TOTAL TIME
Remarks: Id + Out time is time spent filling Water Truek

Terms: net due on the 15th of the month following statement date. Past due amounts will be assessed at 1-1/2\% (one and one half percent) finance charge per month for accounts over thirty days.

Supervisors Signature

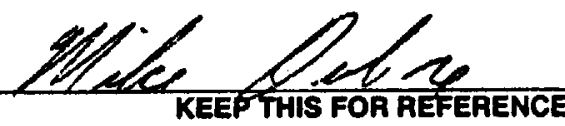


Sandia National Laboratories Tonopah Test Range

Declaration of Non-Hazardous/Non-Radiological Waste

Sandia National Laboratories hereby certifies that the solid waste described below is not a "hazardous waste", as that term is defined in 40 CFR Subpart C. Sandia National Laboratories further certifies that the materials are non-radiological in nature and meet D.O.E. radiological control criteria for release to the general public. This certification is the result of actual testing, surveying, and/or knowledge of the characteristics of the waste based on the materials or processes and/or locations used.

Description of Waste (Check \& complete appropriate Item(s)):

1. Office Refuse

USAF Sanitary Landfill

2. Construction Debris Prot Debris Landfill

Weight of Load:

Weight of Load: 55603

Description of Load: scrap Meta

Method of Waste Characterization

Generator Knowledge

Analytical

Screening Survey

Radiological Survey

Certified BY;
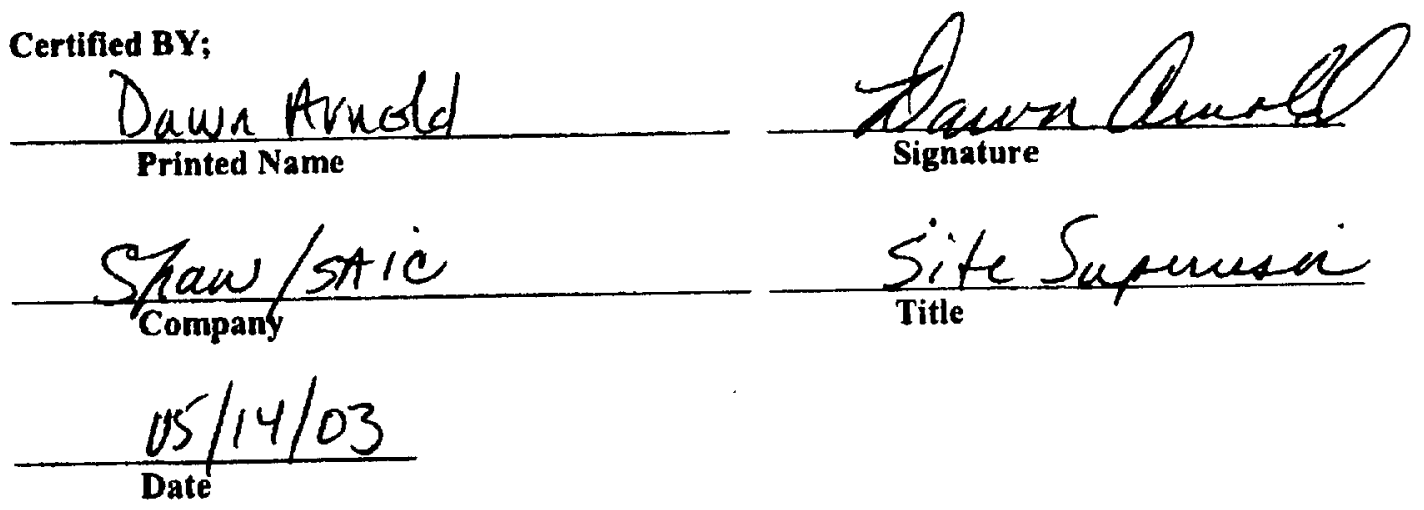
(Waste definitions are available on page 2)

\section{SWO USE (Circle One Area) AREA \\ 23 \\ Y 9 \\ LANDFILL}

For waste characterization, approval, andlor assistance, contact Solid Waste Operation (SWO) at 5-7898.

$$
\text { REQUIRED: WASTE GENERATOR INFORMATION }
$$

(This form is for rolloffs, dump trucks, and other onsite disposal of materials.)

Waste Generator: Brian Konrad

Phone Number: $5-1240$

Location / Origin: CAU 410 Tonopah Test Range

\begin{tabular}{|c|c|c|c|c|}
\hline \multicolumn{2}{|c|}{ Waste Category: (check one) } & Acommercial ins & \multicolumn{2}{|c|}{ Industrial oys $3 / 5103$} \\
\hline Waste Type: & $\square$ NTS & $\square$ Putrescible & $\square$ FFACO-onsite & $\square$ WAC Exception \\
\hline (check one) & $\square$ Non-Putrescible & $\square$ Asbestos Containing Material & X FFACO-offsite & $\square$ Historic DOENV \\
\hline
\end{tabular}

Pollution Prevention Category: (check one) $\quad \mathbb{X}$ Environmental management $\square$ Defense Projects

Pollution Prevention Category: (check one) $\quad X]$ Clean-Up

Method of Characterization: (check one)

X] Sampling \& Analysis

$\square$ Routine

Prohibited Waste

at all three NTS landfills:

Radioactive waste; RCRA waste; Hazardo
wastes (needles, sharps, bloody clothing).

$\square$ Process Knowledge

Contents

Additional Prohlbited Waste Sewage Sludge; Animal carcasses-, Wet garbage (food waste); and Friable asbestos

at the Area 9 U10c Landfill:

REQUIRED: WASTE CONTENTS ALLOWABLE WASTES

Check all allowable wastes that are contained within this load:

NOTE: Waste disposed at the Area 6 Hydrocarbon Landfill must have come into contact with petroleum hydrocarbons or coolants such as: gasoline (no benzene, lead); Jet fuel; diesel fuel; lubricants and hydraulics; kerosene; asphaltic petroleum hydrocarbon; and ethylene glycol.

Acceptable waste at any NTS landfill: $\square$ Paper $\square$ Rocks / unaltered geologic materials $\square$ Empty containers
$\square$ Asphalt
$\square$ Metal
$\square$ Wood
[X] Soil thdine
$\square$ Rubber (excluding tires)
$\square$ Demolition debris

$\square$ Plastic

$\square$ Wire

$\square$ Cable

$\square$ Cloth ifs

$\square$ Insulation (non-Asbestosform)

$\square$ Cement \& corrcrete

$\square$ Manufactured items: (swamp coolers, furniture, rugs, carpet, electronic components, PPE, etc.)

Additional waste accepted at the Area 23 Mercury Landfill: $\square$ Office waste $\square$ Food Waste $\square$ Animal Carcasses

Asbestos: $\square$ Friable $\square$ Non-Friable (contact SWO if regulated load) Quantity:

Additional waste accepted at the Area 9 U10c Landfill:
$\square$ Non-friable asbestos $\square$ Drained automobiles and military vehicles

$\square$ Light ballasts (contact SWO) $\square$ Drained fuel filters (gas \& diesel)

Hydrocarbons (contact SWO)

Additional waste accepted at the Area 6 Hydrocarbon Landfill:
$\square$ Septic sludge $\square$ Rags
$\square$ Drained fuel filters (gas \& diesel)
$\square$ Plants
$\square$ sludge from sand/oil/water separators
$\square$ Crushed non-terne plated oil filters

REQUIRED: WASTE GENERATOR SIGNATURE

Initials: (If initialed, no radiological clearance is necessary.)

The above mentioned waste was generated outside of a Controlled Waste Management Area (CWMA) and to the best of my knowledge, does not contain radiological materials.

To the best of my knowledge, the waste described above contains only thi site. I have verified this through the waste characterization method identif. prohibited and allowable waste items.

Print Name: Allen Alshoesec.

Signature: $\longrightarrow$

Date: 3403

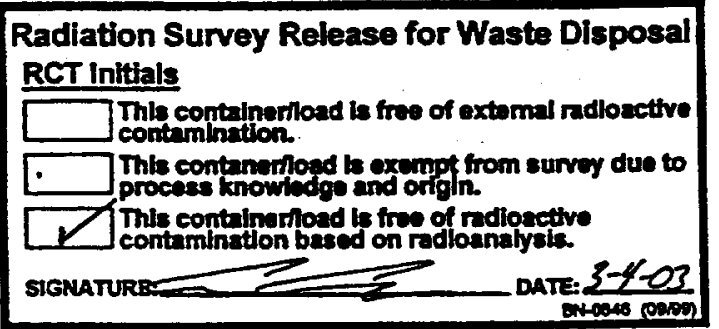

Note: Food waste, office trash and/or animal carcasses are considered not to contain added radioactivity, and therefore do not require a radiological clearance.

Solid fractions from sand/oil/water separators Deconned Underground and Above Ground Tanks 
(Waste definitions are available on page 2)

\section{SWO USE (Circle One Area) AREA \\ 23

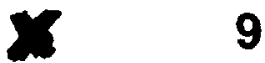 \\ LANDFILL}

For waste characterization, approval, andlor assistance, contact Solid Waste Operation (SWO) at 5-7898. REQUIRED: WASTE GENERATOR INFORMATION

(This form is for rolloffs, dump trucks, and other onsite disposal of materials.)

Waste Generator: Brian Konrad

Phone Number: $5-1240$

Location / Origin: CAU 410 Tonopah Test Range

Waste Category: (check one)

Waste Type:

YCommercial cos

gos

$\square$ Industrial $\mathrm{COS} 3 / \mathrm{s} / \mathrm{C}$

$\square$ WAC Exception

(check one)

$\square$ NTS

$\square$ Non-Putrescible

$\square$ Asbestos Containing Material

X] FFACO-offisite

$\square$ Historic DOENN

Pollution Prevention Category: (check one)

Pollution Prevention Category: (check one)

[] Environmental management

Defense Projects

Method of Characterization: (check one)

[X] Clean-Up

$\square$ Routine

Prohibited Waste

X] Sampling \& Analysis

Process Knowledge

$\square$ Contents

at all three NTS landfills: $\quad$ wastes (needles, sharps, bloody clothing).

Additional Prohibited Waste Sewage Sludge; Animal carcasses-, Wet garbage (food waste); and Friable asbestos

at the Area 9 U10c Landfill:

REQUIRED: WASTE CONTENTS ALLOWABLE WASTES

Check all allowable wastes that are contained within this load:

NOTE: Waste disposed at the Area 6 Hydrocarbon Landfill must have come into contact with petroleum hydrocarbons or coolants such as: gasoline (no benzene, lead); jet fuel; diesel fuel; lubricants and hydraulics; kerosene; asphaltic petroleum hydrocarbon; and ethylene glycol.

Acceptable waste at any NTS landfill: $\quad \square$ Paper $\square$ Rocks / unaltered geologic materials $\quad \square$ Empty containers
$\square$ Asphalt
$\square$ Metal
$\square$ Wood
[X] Soil H, dme
$\square$ Rubber (excluding tires)
$\square$ Demolition debris
$\square$ Plastic
$\square$ Wire
$\square$ Cable
$\square$ Cloth cos
$\square$ Insulation (non-Asbestosform)
Cement \& concrete

Manufactured items: (swamp coolers, furniture, rugs, carpet, electronic components, PPE, etc.)

Additional waste accepted at the Area 23 Mercury Landfill: $\square$ office waste $\square$ Food Waste $\square$ Animal Carcasses

$\square$ Asbestos: $\square$ Friable $\square$ Non-Friable (contact SWO if regulated load) Quantity:

Additional waste accepted at the Area 9 U10c Landfill:
$\square$ Non-friable asbestos
$\square$ Drained automobiles and military vehicles
$\square$ Solid fractions from sand/oil/water separators
$\square$ Light ballasts (contact SWO)
$\square$ Drained fuel filters (gas \& diesel)
$\square$ Deconned Underground and Above Ground
Hydrocarbons (contact SWO)
$\square$ Tanks

Additlonal waste accepted at the Area 6 Hydrocarbon Landfill:
$\square$ Septic sludge $\square$ Rags
$\square$ Drained fuel filters (gas \& diesel)
Plants
Sludge from sand/oil/water separators
$\square$ Crushed non-terne plated oil filters
$\square$ PCBs below 50 parts per million

Initials: REQUIRED: WASTE GENERATOR SIGNATURE

(If initialed, no radjological clearance is necessary.)

The above mentioned waste was generated outside of a Controlled Waste Management Area (CWMA) and to the best of my knowledge, does not contain radiological materials.

To the best of my knowledge, the waste described above contains only thi site. I have verified this through the waste characterization method identif. prohibited and allowable waste items.

Print Name: Allen Allsheuse

Signature: $\simeq$

Date: 3403

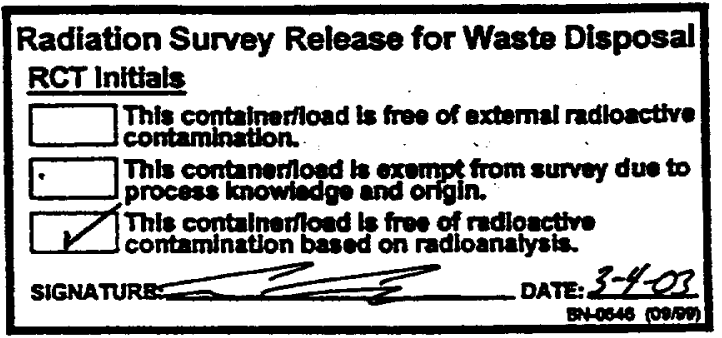

Note: Food waste, office trash and/or animal carcasses are considered not to contain added radioactivity, and therefore do not require a radiological clearance.

SWO USE ONLY
Load Weight (net from scale or estimate): $34.78:$ Signature of Certifier:

Ral.

Dilp 
(Waste definitions are available on page 2)

SWO USE (Circle One Area) AREA

23

$\boldsymbol{x}$

9

LANDFILL

For waste characterization, approval, andlor assistance, contact Solid Waste Operation (SWO) at 5-7898.

REQUIRED: WASTE GENERATOR INFORMATION

(This form is for rolloffs, dump trucks, and other onsite disposal of materials.)

Waste Generator: Brian Konrad

Phone Number: $\mathbf{5 - 1 2 4 0}$

Location / Origin: CAU 410 Tonopah Test Range

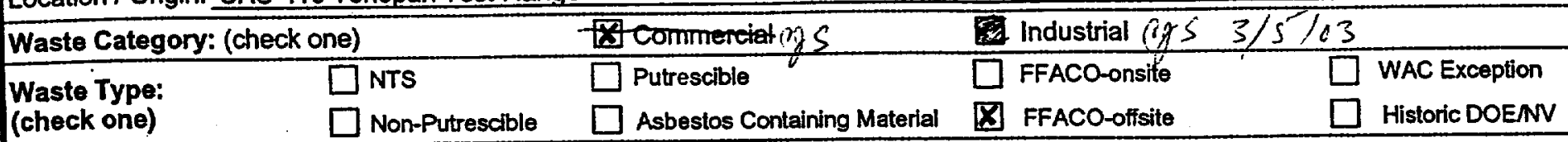

Pollution Prevention Category: (check one)

[X] Environmental management

Defense Projects

Pollution Prevention Category: (check one)

[X Clean-Up

$\square$ Routine

Method of Characterization: (check one)

X Sampling \& Analysis

Process Knowledge

$\square$ Contents

$\begin{array}{ll}\text { Prohibited Waste } & \text { Radioactive waste; RCRA waste; Hazardous } \\ \text { at all three NTS landfills: } & \text { wastes (needles, sharps, bloody clothing). }\end{array}$

Additional Prohiblted Waste Sewage Sludge; Animal carcasses-, Wet garbage (food waste); and Friable asbestos

at the Area 9 U10c Landfill:

REQUIRED: WASTE CONTENTS ALLOWABLE WASTES

Check all allowable wastes that are contained within this load:

NOTE: Waste disposed at the Area 6 Hydrocarbon Landfill must have come into contact with petroleum hydrocarbons or coolants such as:

gasoline (no benzene, lead); jet fuel; diesel fuel; lubricants and hydraulics; kerosene; asphaltic petroleum hydrocarbon; and ethylene glycol.

Acceptable waste at any NTS landfill: $\square$ Paper $\square$ Rocks / unaltered geologic materials $\square$ Empty containers
$\square$ Asphalt
$\square$ Metal
$\square$ Wood
[D] Soil Hydro
Plastic
$\square$ Wire
$\square$ Cable
$\square$ Cloth 49
$\square$ Rubber (excluding tires)
$\square$ Demolition debris
$\square$ Insulation (non-Asbestosform)
Cement \& concrete

$\square$ Manufactured items: (swamp coolers, fumiture, rugs, carpet, electronic components, PPE, etc.)

Additional waste accepted at the Area 23 Mercury Landfill: $\square$ Office waste $\square$ Food Waste $\square$ Animal Carcasses

$\square$ Asbestos: $\square$ Friable $\square$ Non-Friable (contact SWO if regulated load) Quantity:

Additional waște accepted at the Area 9 U10c Landfill:
$\square$ Non-friable asbestos
$\square$ Drained automobiles and military vehicles
Solid fractions from sand/oil/water separators
$\square$ Light ballasts (contact SWO)
Drained fuel filters (gas \& diesel)
$\square$ Deconned Underground and Above Ground
Hydrocarbons (contact SWO)
Tanks

Additional waste accepted at the Area 6 Hydrocarbon Landfill:
$\square$ Septic sludge $\square$ Rags
$\square$ Drained fuel filters (gas \& diesel)
$\square$ Crushed non-terne plated oil filters
$\square$ Plants
$\square$ Sludge from sand/oil/water separators
$\square$ PCBs below 50 parts per million

Initials: REQUIRED: WASTE GENERATOR SIGNATURE

The above mentioned waste was generated outside of a Controlled Waste Management Area (CWMA) and to the best of my knowledge, does not contain radiological materials.

To the best of $m y$ knowledge, the waste described above contains only thi site. I have veriffed this through the waste characterization method identif. prohibited and allowable waste items.

Print Name: Allen Alshouse

Signature:

Note: Food waste, office trash and/or animal carcasses are considered not to contain added radioactivity, and therefore do not require a radiological clearance.

SWO USE ONLY

Load Weight (net from scale or estimate) $25,6.0$

Signature of Certies: 
(Waste definitions are available on page 2)

\section{SWO USE (Circle One Area) AREA \\ 23 \\ 9 \\ LANDFILL}

For waste characterization, approval, andlor assistance, contact Solid Waste Operation (SWO) at 5-7898.

REQUIRED: WASTE GENERATOR INFORMATION

(This form is for rolloffs, dump trucks, and other onsite disposal of materials.)

Waste Generator: Brian Konrad

Phone Number: $5-1240$

Location / Origin: CAU 410 Tonopah Test Range

Waste Category: (check one)

$-\mathrm{X}$ Commerciat $(\hat{y}$

$\square$ Putresciblo

$\square$ NTS

Waste Type:

$\square$ Non-Putrescible

$\square$ Asbestos Containing Material

industrial $(0) 3 / 5 / 03$

(check one)

[] Environmental management

$\square$ FFACO-onsite

WAC Exception

Pollution Prevention Category: (check one)

[X] FFACO-offsite

Historic DOENV

Pollution Prevention Category: (check one)

Method of Characterization: (check one)

X Clean-Up

[X Sampling \& Analysis

$\square$ Defense Projects

Prohiblted Waste

Radioactive waste; RCRA waste; Hazardous waste; Free liquids, PCBs above TSCA regulatory levels-, and Medical at all three NTS landfills:

wastes (needles, sharps, bloody clothing).

Additional Prohibited Waste Sewage Sludge; Animal carcasses-, Wet garbage (food waste); and Friable asbestos

at the Area 9 U10c Landfill:

\section{REQUIRED: WASTE CONTENTS ALLOWABLE WASTES}

Check all allowable wastes that are contained within this load:

NOTE: Waste disposed at the Area 6 Hydrocarbon Landfill must have come into contact with petroleum hydrocarbons or coolants such as: gasoline (no benzene, lead); jet fuel; diesel fuel; lubricants and hydraulics; kerosene; asphaltic petroleum hydrocarbon; and ethylene glycol.
Acceptable waste at any NTS landfill:
Asphalt
$\square$ Metal
$\square$ Wood
$\square$ Paper
$\square$ Soil ffidco
$\square$ Cloth of
$\square$ Rocks / unaltered geologic materials
[] Empty containers
$\square$ Plastic
$\square$ Wire
Cable
$\square$ Rubber (excluding tires)
$\square$ Demolition debris

Manufactured items: (swamp coolers, furniture, rugs, carpet, electronic components, PPE, etc.)

Additional waste accepted at the Area 23 Mercury Landfill: $\square$ Office waste $\square$ Food Waste $\square$ Animal Carcasses

Asbestos: $\square$ Friable $\square$ Non-Friable (contact SWO if regulated load) Quantity:

\section{Additional waste accepted at the Area 9 U10c Landfill:}
$\square$ Non-friable asbestos
$\square$ Drained automobiles and military vehicles
$\square$ Solid fractions from sand/oil/water separators
$\square$ Light ballasts (contact SWO)
Drained fuel filters (gas \& diesel)
$\square$ Deconned Underground and Above Ground
Hydrocarbons (contact SWO)
$\square$ Tanks

Additional waste accepted at the Area 6 Hydrocarbon Landfill:
$\square$ Septic sludge $\square$ Rags
Drained fuel filters (gas \& diesel)
Crushed non-terne plated oil filters
$\square$ Plants
$\square$ sludge from sand/oil/water separators
$\square$ PCBs below 50 parts per million

REQUIRED: WASTE GENERATOR SIGNATURE

Initials:

(ff initialed, no radiological clearance is necessary.)

The above mentioned waste was generated outside of a Controlled Waste Management Area (CWMA) and to the best of my knowledge, does not contain radiological materials.

To the best of my knowledge, the waste described above contains only thi site. I have verffied this through the waste characterization method identif. prohibited and allowable waste items.

Print Name: Allen Alshouse

Signature: Date: 3403

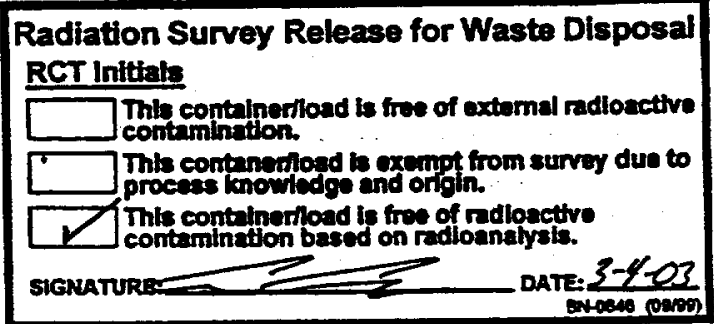

Note: Food waste, office trash and/or animal carcasses are considered not to contain added radioactivity, and therefore do not require a radiological clearance.

\section{SWO USE ONLY}

Load Weight (net from scale or estimate): 30460

Signature of Certifier: 
For waste characterization, approval, and/or assistance, contact SolidtVaste Operation (SWO) at 5-7898.

REQUIRED: WASTE GENERATOR INFORMATION

(This form is for rolloffs, dump trucks, and other onsite disposal of materials.)

Waste Generator: Shaw Environmental, Inc. for U. S. Department of Energy Phone Number: 702 295-3357

Location / Origin: TTR Area $3 /$ CAU 410

\begin{tabular}{|c|c|c|c|c|}
\hline \multicolumn{2}{|c|}{ Wasto Category: (check one) } & \multicolumn{3}{|c|}{ Commercial } \\
\hline Waste Type: & NTS & Putrascible & FFACO-onsite & WAC Exceplion \\
\hline (check one & Non-Putrescible & $\square$ Asbestos Containing Materlal & [X] FFACO-offsile & Mistoric DOENV \\
\hline \multicolumn{2}{|c|}{ Pollutton Prevention Category: (check one) } & [] Environmental management & Defense Projects & YMP \\
\hline \multicolumn{2}{|c|}{ Pollution Prevention Category: (check one) } & [ Clean-Up & Routix & \\
\hline \multicolumn{2}{|c|}{ Method of Characterizatlon: (check one) } & D. Sempling \& Arabysis & Procezs Knowle & Contents \\
\hline
\end{tabular}

Prohibited Wasto

Radoacive waste; RCRA weste; Hazardous waste; Free liquids. PCBs above TSCA regulatory lovels-, and Meodical at all three NTS landiuls: wastes (needles, sharps, bloody ctothing).

Additional Prohbited Waste Sewrge Shodge; Animal carcasses-, Wol garbage (food wasle): and Friable asbestos at the Area 9 U10e Landifll:

\section{REQUIRED: WASTE CONTENTS ALLOWABLE WASTES}

Check all allowable westes that ane contained within this load:

MOTE: Wasto disposed at the Area 6 Hydrocarton Landill must have come into conthet with potroleum hydrocarbons or cootants such as: gasoline (no benzene, lead); jet fuel, diesel fuel: hubricants and hydraulics: kerosene: as phaltic petroleum hydrocarbon; and ethylene olycol

Acceptoble waste at any NTS landfill: $\square$ Paper $\square$ Rocks / unaltered geologic materlals $\square$ Empty containers
$\square$ Asphalt
[B] Metal
[D] Wood
[X] Soil
$\square$ Rubber (excluding tires)
$\square$ Demolition debrls
O. Plastic
X Wire
$\square$ Cable
$\square$ Cloth
$\square$ insulation (non-Asbestosform)
[3] Cement \& concrete

[3] Manufactured items: (swemp coolers, furniture, rugs, carpet, electronic components, PPE. etc.)

Additional waste accepted at the Area 23 Mercury Landml: $\square$ Office waste $\square$ Food Waste $\square$ Animal Carcasses $\square$ Asbestos: $\square$ Frlable $\square$ Non-Friable (contact swo if regulated load) Quantily:

Additional waste accepted at the Area 8 U10c Landifll:
$\square$ Non-friable asbestos
$\square$ Drained automobiles and military vehicles
$\square$ Light ballasts (contact SWO)
Drained fuel fitters (gas \& diesel)
Hydrocarbons (contact SWO)
Other
Solid fractions from sand/oilwaler separalors
$\square$ Deconned Underground and Above Ground
$\square$ Tanks
Additional waste accepted at the Area 6 Hydrocarbon Landfill:
$\square$ Septic sludge $\square$ Rags
$\square$ plants $\quad \square$ Soil
G. Drained fuel fitters (gas \& diesel)
$\square$ Other
$\square$ Sludge from sandloilhwater separators
$\square$ Crushed non-terne plated oll fliters
Initials: $197 z$ REQUIRED: WASTE GEN

Thw above mentoned waste was generated outside of a Controlled Waste Management Area (CWMA) and to the best of my knowledge, does not contain radlological materials.

To the best of $m y$ knowledge, the waste described above contains only those materials that are allowed for disposal at this site. I have verfied this through the waste characterizatlon method identified above and a review of the above-mentloned prohibited and allowable waste kems.

Print Name: John M. Fowler

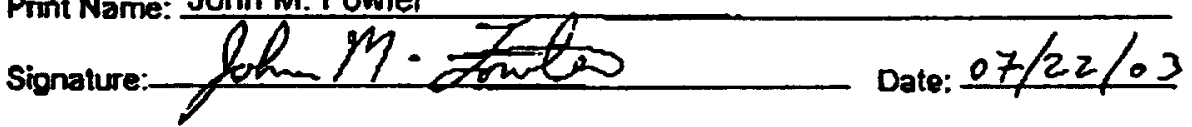

If applicable, place BN-0646, "Radiological Release Sticker" here. Onsite use only.

Note: Food waste. office trash andlor animal carcasses are considered not to contain added radioactivity, and therefore do not require a radiological clearance.

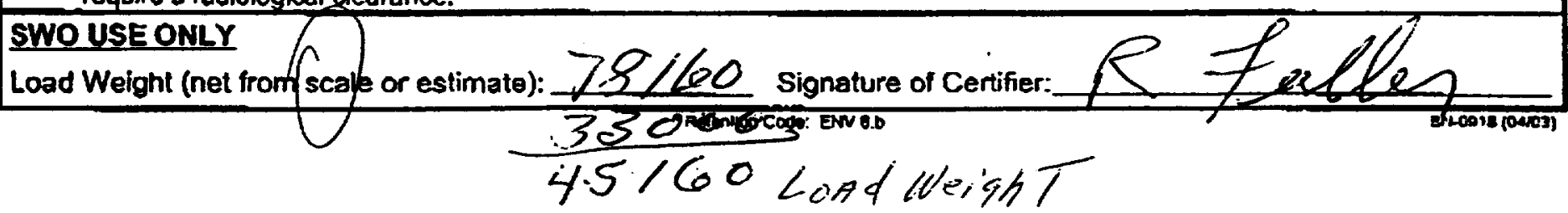


Waste definitions are available on page 2$)$

SWO USE (Circle One Area) AREA

For waste characterization, approval, and/or assistance, contact Solid Wasto Operation (SWO) at 5-7898.

REQUIRED: WASTE GENERATOR INFORMATION

(This form is for rolloffs, dump trucks, and other onsite disposal of materials.)

Waste Generator: Shaw Environmental, Inc. for U. S. Department of Energy Phone Number: 702 295-3357

Location / Origin: TTR Area 3/ CAU 410

Wasto Category: (check one)

$\square$ Commercia!

[] Industrial

Waste Type:

$\square$ NTS

$\square$ Putrescible

FFACO-onsite

WAC Exception

(check one)

$\square$ Non-Putrescible

$\square$ Asbestos Containing Materlal

[B] FFACO-ofisite

[] Environmental management

$\square$ Defense Projects

Mistoric DOENY

Pollution Prevention Category: (check one)

Polhution Prevention Category: (check one)

B] Clean-Up

$\square$ Routine

Mothod of Characterization: (check one)

D. Sampling \& Arabyis

Process Knowledge

YMP

Prohiblted Wasto

Radlogcive waste; RCRA weste; Hazardous waste; Free liquids, PCBs above TSCA regulatory lovels-, and Meơical at all three NTS Indrils: wastes (necolos, sharps, bloody clothing).

Additional Prohiblted Waste Sewage Studge; Animal carcasses., Wol garbago (food wasla): and Friable asbestos at the Area 9 U10e Landill:

REQUIRED: WASTE CONTENTS ALLOWABLE WASTES

Check all allowable westes that are contained within this load:

NOTE: Westo disposed at the Ares 6 Hydrocarbon Landill must hàve come hro contiet with petroleum hydrocarbons or coolants such as: pasoline (no benzene, lead) jet fuel: diesel fuel: lubricants and hydraulic: kerosene; asphallic pelroleum hydrocarbon; and ethylene olycol

Accoptoble waste at any NTS landfill: $\square$ Paper $\quad[$ Rocks / unallered geologic malerlals

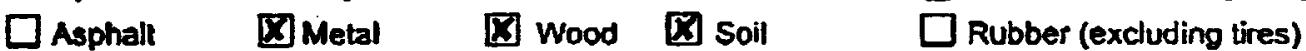

G Plastic $\square$ Wire $\square$ Cable $\square$ Cloth $\square$ insulation (non-Asbestosform)

[2] Manufactured items: (swamp coolers, furniture, rugs, carpet, electronic components, PPE, etc.)

Additional waste accepted at the Area 23 Mercury Landfill: $\square$ Office waste $\square$ Food Waste $\square$ Animal Carcasses

$\square$ Asbestos: $\square$ Frlable $\square$ Non-Friable (contact SWO if regulated load) Quantity:

Additional wast accepted at the Area 8 U10c Landfill:

$\square$ Non-friable asbestos

$\square$ Drained automobiles and miliary vehicles

$\square$ Light ballasts (contact SWO)

$\square$ Drained fuel fiters (gas a diesel)

Other

Additional weste accepted at the Area 6 Hydrocarbon Landfill:

$\square$ septic sludge $\square$ Rags $\quad \square$ Drained luel Alters (gas \& diesel)

$\square$ Plants $\quad[B]$ soil

mitials: $97 \neq$

on in

Sludge from sand/oilwator separators REQUIRED: WASTE GENERATOR SIGNATURE

Tha above mentioned waste was generated outside of a Controlled Waste Management Area (CWMA) and to the best of my knowiedge, does not contain radjological materials.

To the best of $m$ hnowledge, the waste described above contains only those materials that are allowed for disposal at this site. I hove verlifed this through the waste characterizatlon method identified above and a raview of the above-mentloned prohibited and allowable waste liems.

Print Name: John M. Fowler

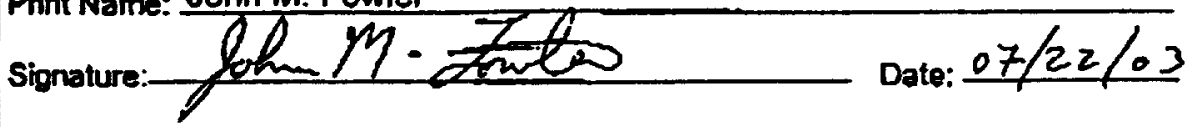

If applicable, place BN-0646, "Radiological Release Sticker" hore. Onsite use only.

Note: Food waste. Office trash and/or animal carcasses are considered not to contain added radioactivity. and therefore do not requirs a radiological clearance.

SWO USE ONLY

Load Weight (net from scale or estimate): $>3, / 6 \mathrm{C}$

Signature of Certifier:

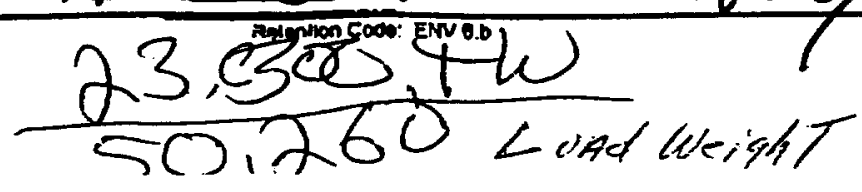


For waste characterization, approval, and/or assistance, contact SoliaWaste Operation (SWO) at 5-7898.

REQUIRED: WASTE GENERATOR INFORMATION

(This form is for rollofis, dump trucks, and other onsite disposal of materials.)

Waste Generator, Shaw Environmenlal, Inc. for U.S. Department of Energy Phone Number: 702 295-3357 Location / Origin: TTR Area 3/ CAU 410

Waste Category: (chock ono)

Waste Type:

(no)

(check ono)

DNTS

एommercial

$\square$ Non-Putrescible

$\square$ Putrascible

X Industrial

Pollution Prevention Category: (check one)

$\square$ Asbestos Contoining Materlal

$\square$ FFACO-onsite

(A) Environmental management

(X) FFACO-offsile

WAC Exception

Pollution Provention Category: (chock one)

Method of Characterizatlon: (check one)

[Q] Clean-Up

D. Sampling \& Aratysis

$\square$ Defense Projects

$\square$ Routine

Prohibitod Wasto

Q Process Knowledge

$\square$ Historic DOENV

at all three NTS landruls:

Radoacive waste; RCRA waste; Hazardo
wastes (needles, sharps, Dloody chothing).

Additional Prohnblted Waste Sewage Shudge; Animal carcasses-, Wol garbage (food waste): and Friable asbestos ot the Aroa 9 U10e Landiill:

REQUIRED: WASTE CONTENTS ALLOWABLE WASTES

Check all allowable wostes that are contained within this load:

NOTE: Wasb disposed at the Aree 6 Hydrocabon Landin must have come into contal with petroleum hydrocarbons or coolants such as:

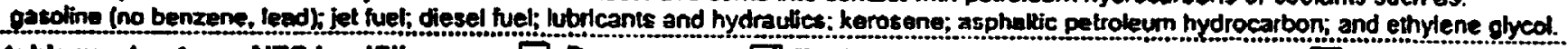

Accoptable waste at any NTS landfill: $\square$ Paper $\quad \square$ Rocks / unallered geologic materlals $\square$ Empty containers

$\square$ Asphall $\square$ Metal $\square$ Wood $\square$ Soil $\square$ Rubber (excluding tires)

O Plastic $\square$ Wire $\square$ Cable $\square$ Cloth . $\square$ insulation (non-Asbestosform)

$\square$ Demolition debris

[D] Manufactured items: (swamp coolers, furniture, rugs, carpet, electronic components, PPE, etc.)

Additional waste accepled at the Area 23 Mercury Landfll: $\square$ Office waste $\square$ Food Waste $\square$ Animal Carcasses

Asbestos: $\square$ Friable $\square$ Non-Friable (contact SWO if regulated load) Quantity:

Additional waste accepted at the Area 9 U10c Landfill:

$\square$ Non-friable asbestos

$\square$ Drained automobiles and military vehicles

$\square$ Light ballasts (contact SWO)

$\square$ Drained fuel fiters (gas \& diesel)

[B] Cement \& concrete

$\square$ Hydrocarbons (contact SWO)

Other

Additional waste accepted at the Area 6 Hydrocarbon Landfill:

$\square$ septic sludge $\square$ Rags $\quad \square$ Drained luel Alters (oas \& diesel)

G Plants [D Soil

$\square$ sludge from sand/oilwater separators REQUIRED: WASTE GENERATOR SIGNATURE

Initials: $197 Z$ REQULRED: WASTE GENE (f initialed, no radiologlesl choorance is necessary.)

The above mentioned waste was generated outside of a Controlled Waste Management Area (CWMA) and to the best of my knowledge, does not contain radiological materials.

To the best of $m y$ knowfodge, the waste deseribed above contains only those materials that are allowed for disposal at this site. I hove verlifed this through the waste characterizatlon method identified above and a review of the above-mentoned prohibited and allowable waste llems.

Print Name: John M. Fowler

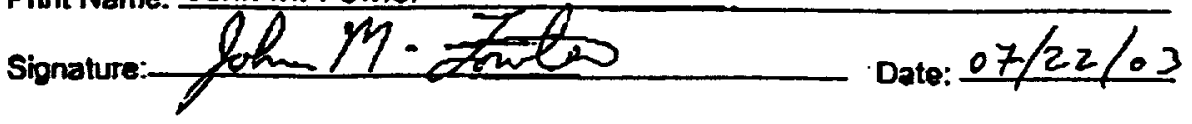

If applicable, place BN-0646, "Radiological Release Sticker" hore. Onsite use only.

Note: Food waste. office trash andlor animal carcasses are considered not to contain added radioactivity, and therefore do not require a radiological clearance.

SWO USE ONLY
Load Weight (net from (scale or estimate) 45,900 Signature of Certifie

$$
33,700
$$


For waste characterization, opproval, and/or assistance, contact Solid Waste Operation (SWO) at 5-7898.

REQUIRED: WASTE GENERATOR INFORMATION

(This form is for rolloffs, dump trucks, and other onsite disposal of materials.)

Waste Generator: Shaw Environmental, Inc. for U. S. Department of Energy

Phone Number: 702 295-3357

Location / Origin: TTR Area 3/ CAU 410

Waste Cotogory: (chock ono)

Waste Type:

NTS

$\square$ commercial

I Industrial

(check one)

$\square$ Non-Putrescible

$\square$ putresciolo

$\square$ FFACO-onsite

WAC Excoption

Pollution Prevention Category: (check one)

$\square$ Asbestos Containing Malerial

[] FFACO-Offisite

Historic DOENV

Pollution Provention Category: (check one)

[X] Environmental management

$\square$ Defense Projects

YMP

Method of Characterizatlon: (check one)

[D] Clean-Up

$\square$ Routine

Prohibited Wasto Radiostive wasto; RCRA woste; Hacardous waste; Free fiquids, PCBs above TSCA regulatory levels-, and Medicol at all three NTS landijls: wastes (necdles, sharps, bloody clothing).

Additional Prohblted Waste Sowage Shudge; Animal carcasses. Wol garbage (tood wasto): and Friable asbestos at the Aroa 9 U10e Landill:

\section{REQUIRED: WASTE CONTENTS ALLOWABLE WASTES}

Check all allowable wastes that are comtained within this load:

NOTE: Weste dispoced at the Ares 8 Hydrocarton Landim must hàve como hto contat with pelrobum hydrocarbons or coolents such as:

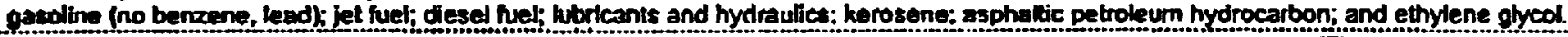
Accoptoble waste at any NTS landfill:
$\square$ Paper
[] Rocks / unaliered geologic matertals
$\square$ Empty containers
$\square$ Asphalt
DNetal
[D] Wood
[Soil
$\square$ Rubber (excluding tires)
T) Plastic
D] Wre
$\square$ cable $\square$ Cloth
$\square$ insulation (non-Asbestosform)
$\square$ Demolition debrls
[B] Cement 8 concrete

[D] Manufactured items: (swamp coolers, tumiture, rugs, carpet electronic components, PPE, etc.)

Additional waste accepted at tho Area 23 Mercury Landill: $\square$ Office waste $\square$ Food Waste $\square$ Animal Carcasses

$\square$ Asbestos: $\square$ Frlable $\square$ Non-Friable (contact swo if regulated load) Quantity:

Addifional waste accepted at the Area 8 U106 Landfill:
$\square$ Non-friable asbestos
$\square$ Drained automobiles and miltiary vehicles
Light ballasts (contact swo)
$\square$ Drained huel niters (gas \& diesel)
Solid fractions from sand/oilwater separators
DHydrocarbons (contact SWO)
Other
$\square$ Deconned Underground and Above Ground
Additional waste accepted at the Area 6 Hydrocorbon Landfill:
$\square$ septic sludge $\square$ Rags
[X] Drained fuel flters (gas \& diesel)
$\square$ Tanks
$\square$ plants LI Soil
$\square$ sludge from sand/oilwrater separators
$\square$ Other
$\square$ Crushed non-terne plated oll fllters

REQUIRED: WASTE GENERATOR SICNATURE

Initials: lyz (II initivied, no radiological clasrance is necessary.)

The above mentloned weste was generated outside of a Controlled Waste Management Area (CWMA) and to the best of my knowlodgo, does nof contein redlological materials.

To the best of $m$ y howtedge, the waste described above contains only those materials that are allowed for disposal at this shte. I have verfited this through the waste cheracterizatlon method identified above and a raviow of the above-mentloned prohibited and allowrable waste Hems.

Print Narne: John M. Fowler

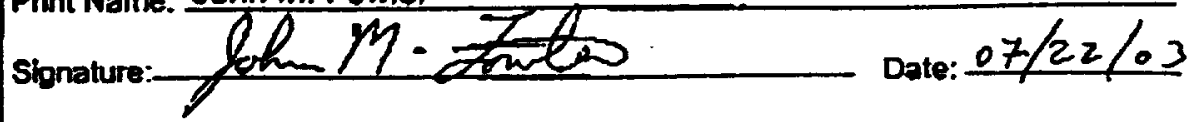

If applicable, place BN-0646, "Radiological Release Sticker" hore. Onsite use only.

Note: Food waste. office trash and/or animal carcasses are considered not to contain added radioactivity, and therefore do not require a radiological clearance.

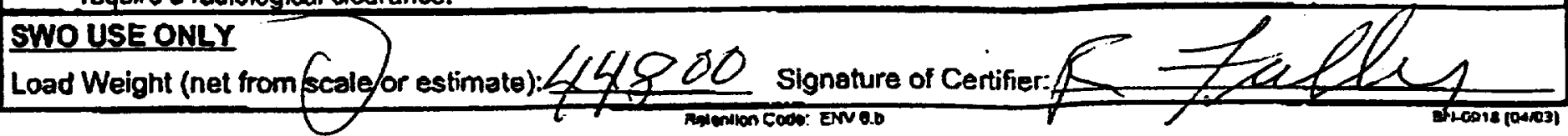


For waste characterization, approval, and/or assistanco, contact SoffitWaste Operation (SWO) at 5-7898.

\section{REQUIRED: WASTE GENERATOR INFORMATION}

(This form is for rolloffs, dump trucks, and other onsite disposal of materials.)

Waste Generator. Shaw Environmental, Inc. for U. S. Department of Energy Phone Number: 702 295-3357

Localion / Origin: TTR Area 3/ CAU 410

Wasto Catogory: (chock ono)

Waste Type:

$\square$ Commercial

B] Industrial

$\square$ Putrescible

$\square$ FFACO-onsile

WAC Excoption

(check ono) $\square$ Non-Putrascible

$\square$ Asbestos Containing Material

[D] FFACO-Ofisite

$\square$ Historic DOENV

Pollution Preventlon Category: (check one)

Pollution Prevention Cotegory: (check one)

Method of Characterization: (check one)

[X] Environmental management

Defense Projects

YMP

Prohibited Wasto

at all three NTS landrills: $\quad$ wastes (needles, sharps, bloody clothing).

D Sampling 8 Analysis

Contents

Additional Prohlbited Waste Sewage Sudge; Animal carcasses., Wot garboge (food waslo): and Friable asbeslos ot the Aros 9 U10e Landilll:

REOUIRED: WASTE CONTENTS ALLOWABLE WASTES

Chock all allowable wastes that are contained within this load:

woTe: Wasto disposed at one Aree 6 Hydrocarion Landili must have como hio contiel with pewoleum hydrocarbons or coolants such as: gasoline (no benzene, leadj jet fuet; diesel fuel: hubricantis and hydraulics: kerosene: asphaltic petroleum hydrocarbon; and ethylene olycol.

Acceptable waste at any NTS landfill: $\square$ Paper $\square$ Rocks / unallered geologic materlals

$\square$ Emply containers

$\square$ Asphall $\quad[$ Metal $\quad[$ Wood $\quad[3$ soil $\square$ Rubber (excluding tires)

B Plastic $\square$ Wire $\square$ Cable $\square$ Cloch $\square$ Insulation (non-Asbestosform)

$\square$ Domolition debris

[3] Cement \& concrete

[D Manufactured items: (swamp coolers, furniture, rugs, carpet, electronic components. PPE. etc.)

Additional waste accepted of the Area 23 Mercury Landill: $\square$ Office waste $\square$ Food Waste $\square$ Animal Carcasses

$\square$ Asbestos: $\square$ Frlable $\square$ Non-Friable (conlact Swo if regulated load) Quantity:

Additional waste accepted at the Area 9 U10c Landifl:
$\square$ Non-friable asbestos
$\square$ Drained automobiles and mlitary vehicles
Light ballasts (contact SWO)
Drained fuel filters (gas \& diesel)
Solid fractions from sand/oilwater separators
Hydrocarbons (contact swO)
Other
$\square$ Deconned Underground and Above Ground
Additional waste accepted at the Area 6 Hydrocarbon Landfill:
$\square$ septic sludge $\square$ Rags
[X] Drainod fuel fitters (oas \& diesel)
Tanks
$\square$ plants $\quad$ S soil
$\square$ Sludge from sand/oilwrater separators
Other REQUIRED: WASTE GENERATOR SJGNATURE

Initials: $17 Z$ (if initialed, no radiologleal cheorence is mecessany.)

The above mentioned waste was generated outside of a Controlled Waste Management Area (CWMA) and to the best of my knowledge, does not contain rodiological materials.

To the best of $m y$ knowledge, the waste described above contains onty those materials thot are allowed for disposal at this site. I have verfifed this through the waste characterization method identified above and a review of the above-mentloned prohibited and allowrable waste liems.

Print Name: John $M$. Fowler

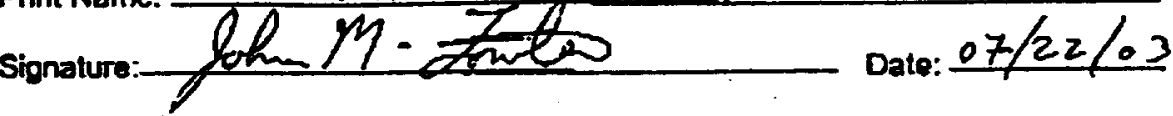

If applicable, place BN-0646, "Radiological Release Sticker" here. Onsite use only.

Note: Food waste, office trash and/or animal carcasses are considered not to coniain added radioactivity, and therefore do not require a radiological clearance.

SWO USE ONLY

Load Weight (net from scals or estimate): 70,662 signature of Certifie

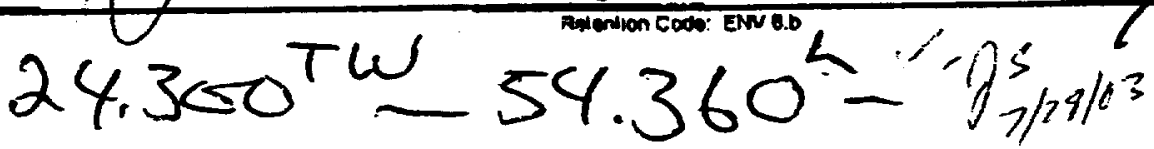


Waste definitions are available on page 2)

\section{SWO USE (Circle One Area) AREA \\ 23 \\ 6 \\ 6 \\ 9 LANDFILL}

For waste characterization, epproval, and/or assistance, contact, Solkt Waste Operation (SWO) at 5-7898.

REQUIRED: WASTE GENERATOR INFORMATION

(This form is for rolloffs, dump trucks, and other onsite disposal of materials.)

Waste Generator. Shaw Environmental, Inc. for U. S. Department of Energy Phone Number: 702 295-3357

Location/Origin: TTR Area $3 /$ CAU 410

\begin{tabular}{|c|c|c|c|c|}
\hline Waste Catog & & Commercial & [X] Industrial & \\
\hline Waste Type: & ] NTS & Putrascible & FFACO-onsile & WAC Exception \\
\hline (check & Non-Putrescible & Asbestos Containing Mralerial & X] FFACO-offsile & Historic DOENV \\
\hline Pollution Prer & ory: (check one) & Q Environmental management & Defense Projects & MMP \\
\hline Pollution Pror & ry: (check one) & [] Clean-Up & Routine & \\
\hline Aethod of Ch & (check one) & I Sampling \& Aralyais & Process Knowled & Contents \\
\hline
\end{tabular}

Prohibitod Vasto

Radoacove waste; RCRA waste; Hacrardous waste; Free liquids, PCBs above TSCA regulatony lovets-, and Medical at all three NTS landrills: wastes (needlos, sharps, oloody clothing).

Additional Prohblited Waste Sowage Shudge; Animal carcasses-. Wol garbage (food wacto): and Friable asbestos of the Area 9 U10c Lanofill:

\section{REQUIRED: WASTE CONTENTS ALLOWABLE WASTES}

Check ell ellowable wastes that are contained within this loed.

MOTE: Waste disposed at the Area 6 Hydrocarton Landill must hàve como hito contat with petroleum hydrocarbons or cootants such as: gosoline (no benzene, lead); jet fuel; diesel huef: hbricants and hydraulics; kerosene; asphalkic petroleum hydrocarbon; and ethylene obcol.

Accoptable waste at any NTS landfill: $\square$ Paper $\quad[$ R Rocks / unallered geologic materlals

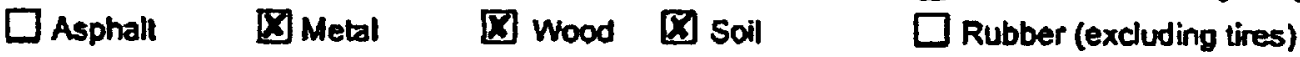

D Plastic $\quad \square$ Wire $\square$ Cable $\square$ Cloth $\square$ insulation (non-Asbestosiorm)

$\square$ Empty containers

$\square$ Demolition debris

[B] Manufactured items: (swamp coolers, furniture, rugs, carpet, electronic components. PPE, etc.)

Additional waste accepted at the Area 23 Mercury Landmi: $\square$ Office waste $\square$ Food Waste $\square$ Animal Carcasses

$\square$ Asbestos: $\square$ Friable $\square$ Non-Friable (contact SWO if regulated load) Quantly:

Additional waste accepted at the Area 8 U10c Landfill:
$\square$ Non-friable asbestos
$\square$ Drained automobiles and military vehicles
$\square$ Light ballasts (contact swO)
$\square$ Drained fuel fiters (gas \& diesel)
Solid fractions from sand/oilwaler separators
$\square$ Hydrocarbons (conlact swo) $\square$ Other
Additional waste accepted at the Area 6 Hydrocarbon Landfill:
$\square$ septic shudge $\square$ Rags $\quad \square$ Drained fuel niters (gas \& diesel)
Dplants D soil
Sludge from sand/oilwater separators

\section{REQUIRED: WASTE GENERATOR SIGNATURE}
REQUIRED: WASTE GEN
Initials: (Y7Z

The above mentoned waste was generated outside of a Controlled Waste Management Area (CWMA) and to the best of my

knowledge, does not contain redtological materials.

To the best of $\mathrm{my}$ knowfedge, the waste described above contains only those materials that are allowed for ofisposal at this site. I have vertied this through the waste characterizallon method identified above and a raviow of the above-mentloned prohibited and allowable waste ffems.

Print Name: John M. Fowler

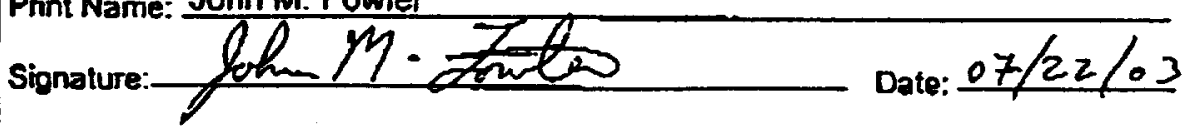

If applicable, place BN-0645, "Radiological Release Sticker" here. Onsite use only.

Note: Food waste. office trash andlor animpl carcasses are considered not to contain added radioactivity, and therefore do not require a radiological clearance.

SWO USE ONLY Load Weight (net from/scale or 


\section{Bechtel Mevada NTS Landfill Load Verification}

Waste definitions are avallable on page 2)

\section{SWO USE (Circle One Area) AREA \\ 23

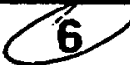 \\ 9 \\ LANDFILL}

For waste characterization, approval, and/or assistance, contact Solid Waste Operation (SWO) at 5-7898.

REQUIRED: WASTE GENERATOR INFORMATION

(This form is for rolloffs, dump trucks, and other onsite disposal of materials.)

Waste Generator. Shaw Environmental, Inc. for W. S. Department of Energy Phone Number: 702 295-3357

Localion / Origin: TTR Area $3 /$ CAU 410

\begin{tabular}{|c|c|c|c|c|}
\hline \multicolumn{2}{|c|}{ Wasta Category: (check ono) } & ZCommercial & \multicolumn{2}{|l|}{ B Industrial } \\
\hline Waste Type: & NTS & Putrescible & FFACO-onsite & WAC Excoption \\
\hline (check one) & Non-Putrescible & $\square$ Asbestos Containing Miatertal & B] FFACO-offsile & Historic DOENV \\
\hline \multicolumn{2}{|c|}{ Pollution Prevention Category: (check one) } & Q Environmental management & Detense Projects & YMP \\
\hline \multicolumn{2}{|c|}{ Pollution Provention Category: (check one) } & [D Clean-Up & Routine & \\
\hline \multicolumn{2}{|c|}{ Method of Charactertzation: (check one) } & DA Sampling \& Arahysis & Process Knowledg & Contents \\
\hline
\end{tabular}

Prohibited Wasto Radosebve waste; RCRA waste; Hazardous waste; Free liquids, PCBs above TSCA regulatory levels-, and Medical at all three NTS landilils: wastes (neodies, sharps, bloody cothing).

Additional Prohiblted Waste Sewage Studge; Animal carcasses-, Wot garbago (lood waste); and Friable asbectos

at the Area 9 U10e Landill:

REQUIRED: WASTE CONTENTS ALLOWABLE WASTES

Check all allowable westes that are contained within this load:

NOTE: Wast disposed at the Area 6 Hydrocarton Landiil must have come hlo contet with pelroleum hydrocarbons or coolants such as:

gatoline (no benzene, lead); jel fuel; diesel huel; hbricants and hydrautica: keroseno; asphallic petroleum hydrocarton; and ethylene olycol.

Accepteble waste at any NTs landfill: $\square$ Paper $\quad[$ Rocks / unallered geologic materlals $\square$ Empty containers
$\square$ Asphall
[Detal
[S Wood
[D Soil
$\square$ Rubber (excluding tires)
$\square$ Insulation (non-Asbestosform)
$\square$ Demolition debrts
E) Plastic
[D Wire
$\square$ Cable $\square$ Cloth
[B] Cement \& concrete

[D Manufactured items: (swamp coolers, furniture, rugs, carpet, electronic components. PPE. etc.)

Additional waste accepted at the Area 23 Mercury Landfill: $\square$ Office waste $\square$ Food Waste $\square$ Animal Carcasses

$\square$ Asbestos: $\square$ Frtable $\square$ Non-Friable (contact SwO if regulated load) Quantly:

Additional waste accepted at the Area 9 U10c Landfill:
Don-friable asbestos
$\square$ Drained automobiles and military vehicles
Light ballasts (contact SWO)
Drained fuet inters (gas \& diesel)
Solid fractions from sand/oilwater separators
Hydrocarbons (contact swo) $\square$ Other
Additional waste accepted at the Area 6 Hydrocarbon Landfill:
$\square$ septic shudge $\square$ Rags
Q Drained luel Alters (gas \& diesel)
$\square$ piants $\quad$ L soil
$\square$ sludge from sand/oikwetor separators
Deconned Underground and Above Ground
Initials: $197 z$
(if initialed, no radiologlcal elearance is necessany.)

\section{REQUIRED: WASTE GENERATOR SIGNATURE}
$\square$ Tanks

The above mentloned waste was generated outside of a Controlled Waste Management Area (CWMA) and to the best of my knowtedge, does not contain rediological materials.

To the best of $\mathrm{my}$ knowledge, the weste described above contains only those materials thet are allowed for disposal at this site. I have verfited this through the waste choracterizatlon method identified above and a review of the above-mentloned prohibited and allowable waste hems.

Print Narre: John M. Fowler

Signature: $y=$ Date: $07 / 22 / 03$

If applicable, place BN-0646,

"Radiological Release Sticker"

hore. Onsite use only.

Note: Food waste. office trash andlor animal carcasses are considered not to contain added radioactivity, and therefore da not require a radiological clearance.

SWO USE ONLY 


\section{$\longrightarrow$}

(Waste definitions are available on pege 2)

\section{SWO USE (Circle One Area) AREA \\ 23 \\ 6 \\ 9 \\ LANDFILL}

For waste characterization, approval, ond/or assistance, contact SoldWWaste Operation (SWO) at 5-7898.

REQUIRED: WASTE GENERATOR INFORMATION

(This form is for rollotfs, dump irucks, and other onsite disposal of materials.)

Waste Generator. Shaw Environmental, Inc. for U. S. Department of Energy Phone Number: 702 295-3357

Location / Origin: TTR Area 3/ CAU 410

\begin{tabular}{|c|c|c|c|c|}
\hline \multicolumn{2}{|c|}{ Waste Category: (check ono) } & \multicolumn{2}{|c|}{ Commercial } & \multirow{3}{*}{$\begin{array}{l}\text { WAC Exception } \\
\text { Historic DOENY }\end{array}$} \\
\hline Waste Type: & NTS & Putrescible & FFACO-onsite & \\
\hline (check one) & Non-Putrescible & Asbestos Containing Material & X FFACO-offsito & \\
\hline \multicolumn{2}{|c|}{ Pollution Preventlon Category: (check one) } & Q] Énironmental managernent & Defense Projects & YMP \\
\hline \multicolumn{2}{|c|}{ Pollution Provention Category: (check one) } & D] Clean-Up & Routine & \\
\hline \multicolumn{2}{|c|}{ Method of Characterization: (check one) } & S Sampling \& Aralysis & Process Knowledge & Contents. \\
\hline
\end{tabular}

Prohibitod Wasto

Radloaelve waste; RCRA waste; Hacardovs waste; Free fiquids, PCBs above TSCA regulatory levels-, and Medicot at all three NTS landills: wastes (needles, sharps, bloody clothing).

Additional Prohblted Waste Sewage Shudge; Animal carcasses.. Wol garbago (food waste); and Friable gsbeslos at the Area 9 Ujoc Landill:

\section{REQUIRED: WASTE CONTENTS ALLOWABLE WASTES}

Chock oll allowable westes that are contained within this load:

NOTE: Waste disposed at the Area $B$ Hydrocarbon Landili must have come into contiet with pelroleum hydrocarbons or coolants such as: gasoline (no benzene, lead); jet fuel: diesel huel: hubrlcants and hydrauliet: kerosene; asphaltic petroleum hydrocarton; and ethylene olyect.

Acceptable waste at any NTS landfill: $\square$ Paper $\quad[\mathrm{g}$ Rocks / unaltered geologic materlals
$\square$ Asphall
[Metal
[D] Wood
[D] Soil
$\square$ Rubber (excluding tires)
[F] Plastic
[D] Wire
$\square$ Cable $\square$ Cloth
$\square$ insulation (non-Asbestosform)
$\square$ Demolition debrls
[D. Cement \& concrete

$\square$ Empty containers

[D Manutactured items: (swamp coolers, fumiture, rugs, carpet, electronic components, PPE, etc.)

Additional waste accepted at the Area 23 Mercury Landill: $\square$ Office waste $\square$ Food Waste $\square$ Animal Carcasses

$\square$ Asbestos: $\square$ Friable $\square$ Non-Friable (contact SwO if regulated load) Quantity:

Additional wasto accepted at the Area 8 U10c Landfill:
$\square$ Non-friable asbestos
$\square$ Drained automobiles and military vehicles
$\square$ Light ballasts (contact SWO)
Drained fuel fitters (gas a diesel)
Solid frections from sand/oil/waler separators
Hydrocarbons (contact SWO)
Other
$\square$ Deconned Underground and Above Ground
Additional woste accepted of the Area 6 Hydrocarbon Landfill:
$\square$ Septic sludge $\square$ Rags
[.] Drained luel flters (gas \& diesel)
Tanks
$\square$ Septic sludge $\square$ Diants
$\square$ shudge from sand/oil/wator separators
$\square$ Other
$\square$ Crushed non-terne plated oll filters
Initials: $157 Z$ REQUIRED: WASTE GENEA (Initisled, no ractiologleal clearance is mecessary.)

The above mentoned wasto was generated outsido of a Controlled Waste Management Area (CWMA) and to the best of my tonowledge, does not contain radjological materials.

To the best of $\mathrm{my}$ knowledge, the waste described above contains only those materials that are allowed for disposal at this site. I heve verifed this through the waste charecterizatlon method identified above and a review of the above-mentloned prohibited and aflowable waste hems.

Print Name: John M. Fowler

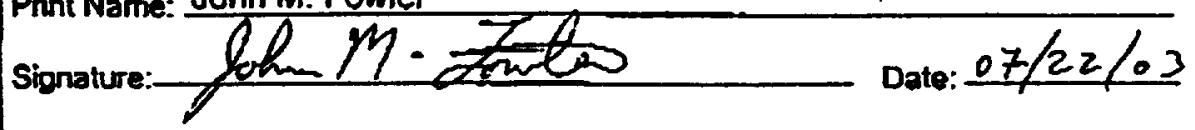

If applicable, place BN-0646, "Radiological Release Sticker" hero. Onsite use only.

Note: Food waste. office trash and/or animal carcasses are considered not to contain added radioactivity, apd therefore do not require a radiological clearance.

SWO USE ONLY 
For waste charactenzation, epproval, andlor assistanco, contact Solid Waste Operation (SWO) at 5-7898.

REQUIRED: WASTE GENERATOR INFORMATION

(This form is for rolloffs, dump incks, and other onsite disposal of materials.)

Waste Generator: Shaw Environmental. Inc. Ior U. S. Department of Energy Phone Number: 702 295-3357 Localion / Origin: TRR Area 3/ CAU 410

Wasto Catogory: (check ono)

Waste Type:

(check ono) $\square$ Non-Putrescible

Q Commercial

$\square$ NTS

$\square$ Putrescibio

A Indusirial

Pollution Prevention Category: (check one)

Pollution Provention Category: (chock one)

$\square$ Asbestos Containing Mialerial

$\square$ FFACO-onsile

[ Emvironmental management

(X] FFACO-Olisite

[B] Clean-Up

Method of Characterization: (check one)

A Sampling \& Anetysis

$\square$ Delense Projects

WAC Exception

Prohibltod Wasto

at all three NTS bandrills:

Routine

D Process Knowledge

wastes (needlos, sharps, bloody dothing).

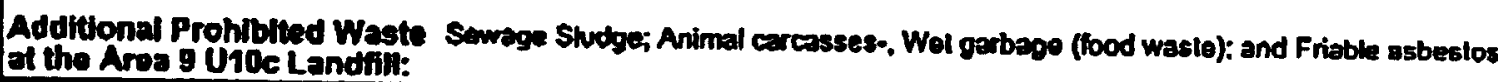

REQUIRED: WASTE CONTENTS ALLOWABLE WASTES

Chock all ollowable wastes that an contained within this load:

MOTE: Weste diapoend at the Area 8 Hydrocarbon Landin must have come hlo contact with petroleum hydrocarbons or coolants such as:

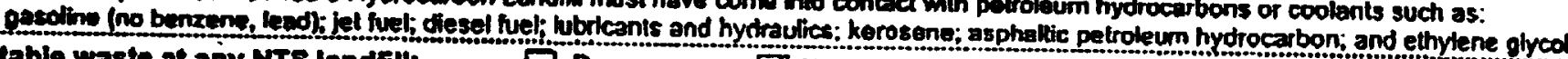
Accoptoble waste at any NTS landill:
$\square$ Paper
[] Rocks / unallered geologic materlals
$\square$ Rubber (excluding tires)
$\square$ insulation (non-Asbestosform)
$\square$ Empty containers
$\square$ Asphah
D) Metal
[D] Wood
[S Soll
D Wro
$\square$ Cable
$\square$ Cloth
$\square$ Demolition debrts

D] Manulactured hems: (swamp coolers, fumilure, rugs, carpet, electronic components. PPE, etc.)

Additional waste accepted at the Arọa 23 Mercury Landill: $\square$ Office waste $\square$ Food Waste $\square$ Animal Carcasses

$\square$ Asbestos: $\square$ Frlable $\square$ Non-Friable (conlact swo if regulated load) Quantity:

Additional wast accepted at the Area o U10e Landill:

$\square$ Non-friable asbestos

$\square$ Lighi ballasts (contact SWO)

$\square$ Hydrocarbons (contact sWO)

$\square$ Drained automobiles and mlitary vehicles

$\square$ Drained fuel fitters (gas 8 diesel) Other

Additional waste accepled at the Area 6 Hydrocarbon Landfill:

$\square$ seplic studge $\square$ Rans

$\square$ plants

[i] Soil
B] Drained fuel niters (gas \& diesel)

$\square$ Sludoe from sand/oilwater separators

Initials: $1 / 7 z$

REQUIRED: WASTE GENERATOR SIGNATURE

Solid fractions from sand/oilwwaler separators

$\square$ Deconned Underground and Above Ground Tanks

Q Other

$\square$ Crushed non-terne plated oll filters

PCBs below 50 parts per million (if initialed, no radiological clasance is necessany.)

The above mentioned waste was generated outside of a Controlled Waste Management Area (CWMA) and to the best of my
knowlodge, does not contain radlological materials.

To the best of $m y$ knowlodge, the waste described above contains only those materials that are allowed for disposal at this site. I hove vertifed this through the wasto cherecterizallon method identified above and a reviow of the above-mentloned
prohibited and allowable waste hems.

Print Name: John M. Fowler

Signature: Date: $07 / 22 / 03$

If applicable, place BN-0646,

"Radiological Release Sticker" hare. Onsite use only. Note: Food waste. office trash and/or animal carcasses are considered not to contain added radioactivity. and therefore do not
require a radiological clearance.

SWO USE ONYY

Load Weight (net from scale of filimate): $Q \mathrm{Q}, \mathrm{QP}$

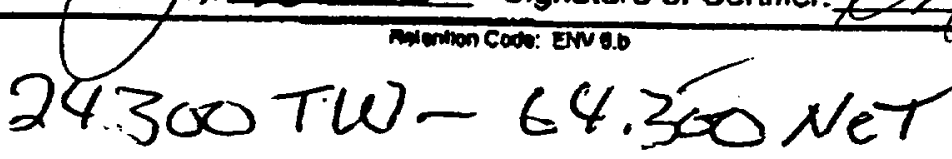

랑o두 (0403) 
For waste characterization, approval, ond/or assistance, contact Solid Wa ste Operation (SWO) at 5-7898. REQUIRED: WASTE GENERATOR INFORMATION

(This form is for rolloffs, dump trucks, and other onsite disposal of materials.)

Waste Generator: Shaw Environmental, Inc. for U. S. Department of Energy Phone Number: $702^{\prime 2} 295.3357$ Location / Origin: TTR Area $3 /$ CAU 410

Waste Catogory: (chock ono)

Waste Type: $\square$ NTS

(check one)

$\square$ Non-Putrescible

$\square$ Commercial

$\square$ Putrescible

[X] Industrial

Pollution Prevention Calegory: (check one)

$\square$ Asbestos Containing Molerial

$\square$ FFACO-onsile

WAC Excoption

D Environmental management

[X] FFACO-ofisile

Historic DOENY

Pollution Provention Category: (chock one)

[D Clean-Up

Method of Characterization: (check one)

DI Sampling \& Analyois

$\square$ Delense Projects

YMP

Prohibited Wisto

at all three NTs landinis:

Drocess Knowledge

Additional Prohiblied Waste Sawage Shudge; Animal carcasses., Wol gabage (food wacto): and Friable asbestos of the Aros 9 U1be Landill:

Rodioscion watto; RCRA waste; Hazerdous

wastes (neadies, shoms, bloody clothing).

. REQUIRED: WASTE CONTENTS ALLOWABLE WASTES

Check all elloweble westes that are comtained within this load:

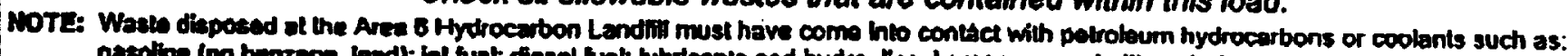

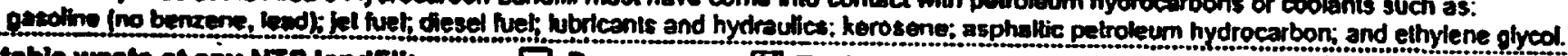

Accoptoble waste at any NTS landfill: $\square$ Paper $\quad$ Q] Rocks / unaltered geologic materlals $\square$ Empty conlainers

$\square$ Asphan $[$ Metal $[\mathrm{D}$ wood $[\mathrm{G}$ soil $\square$ Rubber (excluding tires)

E. Plastic $\quad \square$ mre $\square$ Cable $\square$ Cloth. $\square$ Insulalion (non-Asbestosform)

DJ Manufactured hems: (swamp coolers, furniture, rugs, carpet, electronic components, PPE. elc.)

Additional waste acceptod at the Aroa 23 Mercury Landfill: $\square$ Office waste $\square$ Food Waste $\square$ Animal Carcasses $\square$ Asbeslos: $\square$ Frtable $\square$ Non-Friable (contact swo if regulated load) Quantity:

\section{Additional wasto accepted at the Area 9 U10c Landfill:}
Non-friable asbestos
$\square$ Drained automobiles and military vehicles
Light ballasts (contact swo)
$\square$ Drained fuel filters (gas a diesel)
Hydrocarbons (contact SWO) Other

Additional wate accepted at the Area 6 Hydrocarbon Landfill:

$\square$ Septic shudoe. $\square$ Rags $\quad[$ ] Drained fuel miters (gas \& diesel)

Dianls [i] soil

Shudge from sand/oikwator soparators

$\square$ Demolition debrts

[D Cement \& concrete

Initials: IyzZ REQURED: WASTE GENERATOR SIGNATURE

The above mentoned waste was genterated outside of a Controlled Waste Management Area (CWMA) and to the best of my knowledoe, does nol contain rodological materials.

To the best of $\mathrm{my}$ hnowindge, the waste described above contains only those materials that are allowed for disposal at this sife. I have verlifed this through the wasto characterizallon method identified above and a review of the above-mentloned prohibitod and allowable waste Kems.

Print Name: John M. Fowler

Signature: $y$ other 17 Date: $07 / 22 / 03$

If applicable, place BN-0645, "Radiological Release Sticker" here. Onsite use only.

Note: Food waste. Office trash andior animal carcasses are considered not to contain added radioactivily, and therefore do not reguiro a radiological clearance.

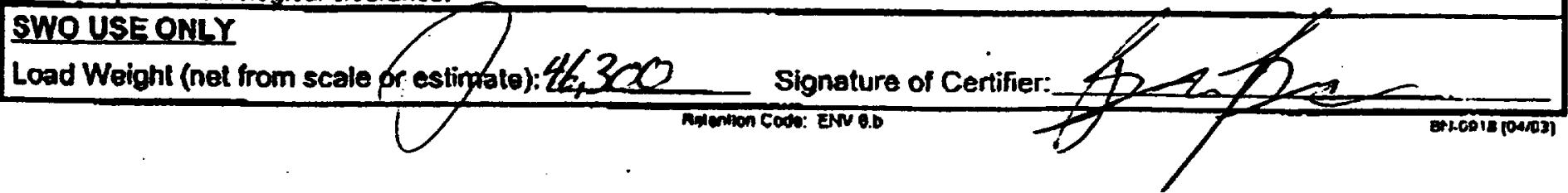


For waste characterization, opproval, and/or assistance, contact Solid Wasfo Operation (SWO) at 5-7898.

REQUIRED: WASTE GENERATOR INFORMATION

(This form is lor rolloffs, dump trucks, and other onsifo disposal of materials.)

Waste Generator: Shaw Environmental, Inc. for U S. Department of Energy Phone Number: 702 295.3357

Localion / Origin: TIRARea 3/CAU 410

Wasto Category: (chock ono)

Waste Type:

$\square \mathrm{NTS}$

$\square$ Non-Putrescible

$\square$ Commercial
$\square$ Putrasciblo
$\square$ Asbestos Containing Naterial

X] Industrial

(check ono)

(1) Environmental management

$\square$ FFACO onsile

[X] FFaco-ofisile

WAC Exception

Pollution Prevention Category: (check one)

Pollution Provention Category: (check one)

Method of Charactertzation: (check one)

[D] Clean-Up

D Sompling \& Aralysh

$\square$ Detense Projects

$\square$ Routine

Prohibltad Wasto

Rodioscive waslo: RCRA waste; Hazardo
wastes (neodos, shorps, bloody clothing).

at all three NTS landiuls:

Additional Prohplited Waste Suwage Shdge; Animal carcasses-, Wot gerbago (food wacto): and Friable asbestos

a the Aroe 8 U1De Landill:

REQUIRED: WASTE CONTENTS ALLOWABLE WASTES

Check all dllowable westes that are contained within this load:

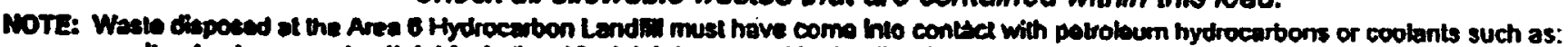

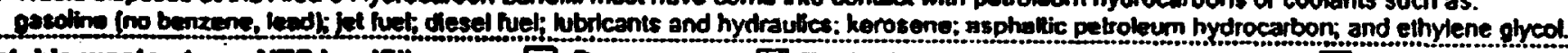

Acceptable waste at any NTS landfill: $\square$ Paper $\square$ Rocks / unallered geologic malerials $\square$ Empty containers

$\square$ Asphall $\quad[$ Motal $\square$ Wood $\square$ soll $\square$ Rubber (excluding tires)

E) Plastic $\quad \square$ Wro $\square$ cable $\square$ Cloth . $\square$ insulation (non-Asbestosform)

B] Manufactured hems: (swamp coolers, fumilure, rugs, carpel, electronic components. PPE. etc.)

Additional wate accepted at the Area 23 Mercury Landnil: $\square$ Office waste $\square$ Food Waste $\square$ Animal Carcasses

$\square$ Asbeslos: $\square$ Friable $\square$ Non-Friable (contect SWO if regulated load) Quantity:

\section{Additional wist accepted at the Area 9 U10c Landinl:}

$\square$ Non-fiable asbestos $\square$ Drained automobiles and military vehicles
$\square$ Light ballasts (contact SWO) $\square$ Drained fuel niters (gas \& diesel)
$\square$ Hydrocarbons (contact SWO) $\square$ Other

Additional waste accepted at the Area 6 Hydrocarbon Landfill:

$\square$ seplic shdge $\square$ Rags $\quad[$ Drained fuel miers (gas \& diesel)

$\square$ plente $[\mathrm{G}$ soil

$\square$ Shudge from sand/ollwator seperators

$\square$ Demolition debris

[B] Cement \& concrete

Initials: $\ln z$ REQUIRED: WASTE GENERATOR SIGNATURE

(If initialed, no rodlologlesl cloorance is mecessary.)

The above mentioned waste was generated outside of a Controlled Waste Management Area (CWMA) and to the best of my knowlodoe, does not contain rediological materials.

To the best of my hnowtedge, the waste described above contains only those materials thot are allowed for disposal at this sthe. I have vertified this through the wasto characterization method identified above and a review of the above-mentloned prohibited and allowable waste hems.

Print Name: John M. Fowler

Signature:

If applicable, place BN-0646,

"Radiological Release Sticker"

hero. Onsite use only.

Note: Food waste. office trash and/or animal carcasses are considered nol to conlain added radioactivity, and therefore do not requiro a rediological clearance.

SWO USE ONLY

Load Weight (net from scale or

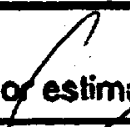




\section{HAZTRAK ENTRY CONFIRMATION}

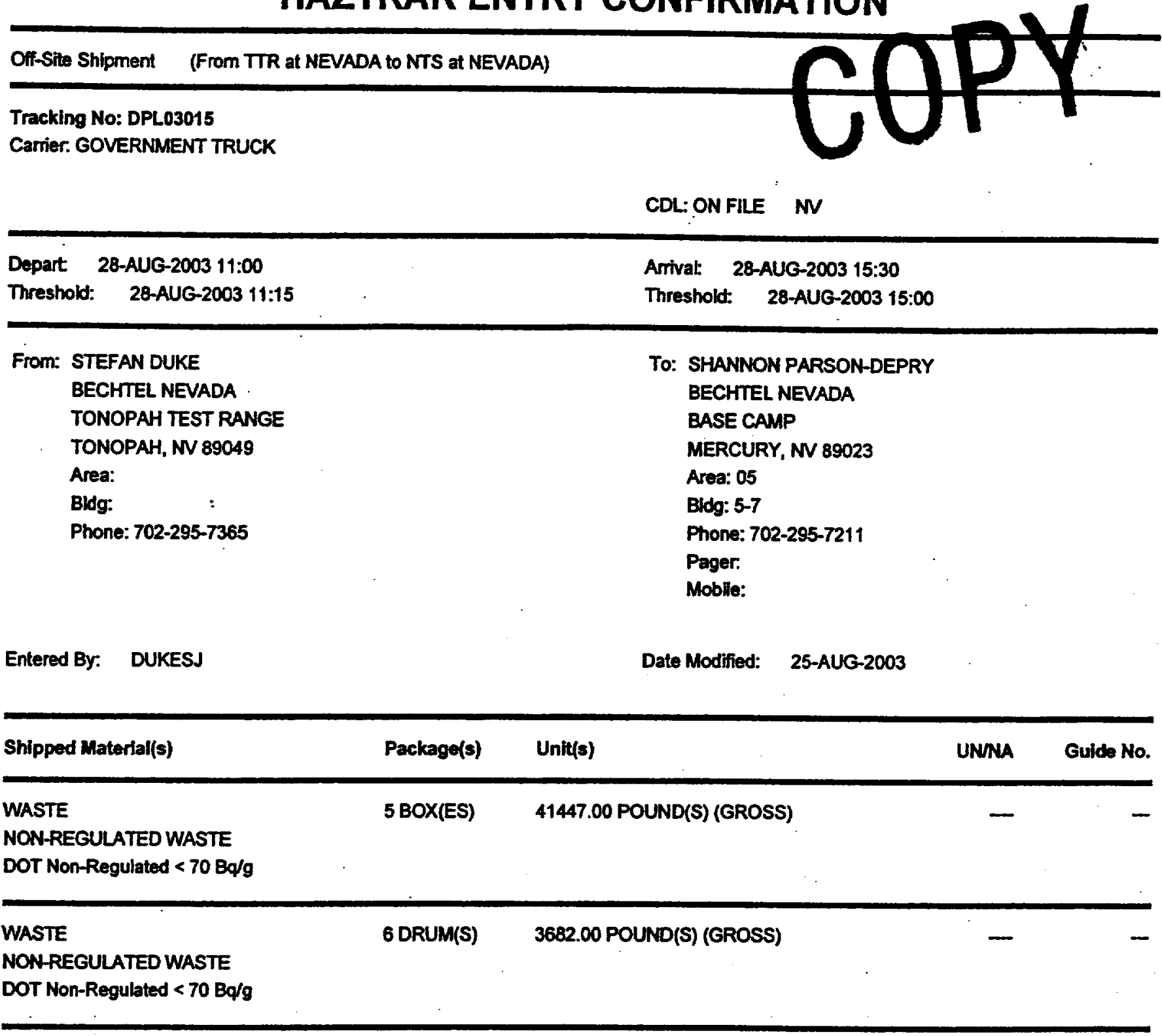

\section{4-Hr Emergency Response Number}

702-295-0311 


\section{Package Storage and Disposal Request}

Shipment Number. DPL03015

Date: $10-\operatorname{Sep}-2003$

Prepared By:

Manifest Number

$\begin{array}{llllll}\text { Package No: } & 03 \text { LO20 } & \text { Contact }(\mathrm{mSv} / \mathrm{h}): & 0.0005 & \text { Completed Date: } & \text { 18-Mar-2003 } \\ \text { Container Code: } & 102 & 1 \text { Meter }(\mathrm{mSV} / \mathrm{h}): & 0.0005 & \text { Operation Type: } & \text { B } \\ \text { External Volume }\left(\mathrm{m}^{\wedge} \text { 3) }\right. & 2.265 E-01 & \text { Gross Weight }(\mathrm{kg}): & 2.680 \mathrm{E}+02 & \text { Total Activity }(\mathrm{bq}): & 5.076 E+05 \\ \text { Waste Volume }\left(\mathrm{m}^{\wedge} 3\right): & 1.980 E-01 & \text { Net Weight }(\mathrm{kg}): & 2.440 E+02 & \text { Activity Date: } & \text { 07-Aug-2003 }\end{array}$

Comment:

\begin{tabular}{|c|c|c|c|c|c|c|c|c|}
\hline $\begin{array}{l}\text { Waste Stream } \\
\text { Profile }\end{array}$ & $\begin{array}{l}\text { Form } \\
\text { Code }\end{array}$ & $\begin{array}{c}\text { Form } \\
\text { Description }\end{array}$ & $\begin{array}{c}\begin{array}{c}\text { Treatment } \\
\text { Code }\end{array} \\
\end{array}$ & $\begin{array}{l}\text { Treatment } \\
\text { Description }\end{array}$ & $\begin{array}{l}\text { Rev. } \\
\text { No. }\end{array}$ & $\begin{array}{c}\text { Revision } \\
\text { Date }\end{array}$ & Nuclide & $\begin{array}{l}\text { Qty } \\
(B q)\end{array}$ \\
\hline LRYSULYOO0018 & 022 & & 100 & & 03 & 01-hu1-2003 & 10-238 & 4A00E+05 \\
\hline LRYSLIFYOCO18 & 022 & & 100 & & 103 & $01-\sqrt{2}-2003$ & $0-235$ & $5600 E+03$ \\
\hline LRYSULFYODO18 & 022 & & 100 & & 03 & $01-\sqrt{41-2003}$ & U.234 & $6200 E+04$ \\
\hline
\end{tabular}

Package No:

Container Code:

External Volume $\left(\mathrm{m}^{\wedge} 3\right)$ 2.265E-01

Waste Vohme (m^3): 1.980E-01 Comment:

$\begin{array}{llll}\text { Contact }(\mathrm{mSw} / \mathrm{h}): & 0.0005 & \text { Completed Date: } & 18-\mathrm{Mar}-2003 \\ 1 \text { Meter }(\mathrm{mSv} / \mathrm{h}): & 0.0005 & \text { Operation Type: } & \text { B } \\ \text { Gross Weight }(\mathrm{kg}): & 2.720 \mathrm{E}+02 & \text { Total Actwity (bq): } & 5.187 \mathrm{E}+05 \\ \text { Net Weight }(\mathrm{kg}): & 2.490 \mathrm{E}+02 & \text { Activity Date: } & \text { 07-Aug-2003 }\end{array}$

\begin{tabular}{|c|c|c|c|c|c|c|c|c|}
\hline $\begin{array}{c}\text { Waste Stream } \\
\text { Profile }\end{array}$ & $\begin{array}{l}\text { Form } \\
\text { Code }\end{array}$ & $\begin{array}{c}\text { Form } \\
\text { Description }\end{array}$ & $\begin{array}{c}\text { Treatment } \\
\text { Code }\end{array}$ & $\begin{array}{l}\text { Treatment } \\
\text { Description }\end{array}$ & $\begin{array}{l}\text { Rev. } \\
\text { No. }\end{array}$ & $\begin{array}{c}\text { Revision } \\
\text { Date }\end{array}$ & Nuclide & $\begin{array}{l}\text { Qty } \\
\text { (Bq) }\end{array}$ \\
\hline LRYSLLFYO0018 & 022 & & 100 & & 03 & $04-\sqrt{u}-2003$ & 11.238 & $45035+05$ \\
\hline LRY5UFY00018 & 022 & & 100 & & $\mathbf{0 3}$ & 01 JuL2003 & U-235 & $5700 E+03$ \\
\hline LRYSLIFYCOO18 & 022 & & 100 & & $\mathbf{0 3}$ & $01-\sqrt{2} u k 2003$ & U.234 & 6.300E+04 \\
\hline
\end{tabular}

$\begin{array}{llllll}\text { Package No: } & 03 L 022 & \text { Contact }(\mathrm{mSv} / \mathrm{h}): & 0.0005 . & \text { Completed Date: } & 18-\mathrm{Mlar}-2003 \\ \text { Container Code: } & 102 & 1 \text { Meter }(\mathrm{mSv} / \mathrm{h}): & 0.0005 & \text { Operation Type: } & \text { B } \\ \text { Extemal Volume }\left(\mathrm{m}^{\wedge} 3\right) & 2.265 E-01 & \text { Gross Weight }(\mathrm{kg}): & 2.770 E+02 & \text { Total Activity (bq): } & 5.298 E+05 \\ \text { Waste Volume }\left(\mathrm{m}^{\wedge} 3\right): & 1.980 E-01 & \text { Net Weight }(\mathrm{kg}): & 2.530 E+02 & \text { Activity Date: } & 07-\text { Aug-2003 }\end{array}$

Comment:

\begin{tabular}{|c|c|c|c|c|c|c|c|c|}
\hline $\begin{array}{c}\text { Waste Stream } \\
\text { Profile }\end{array}$ & $\begin{array}{l}\text { Form } \\
\text { Code }\end{array}$ & $\begin{array}{c}\text { Form } \\
\text { Description }\end{array}$ & $\begin{array}{c}\text { Treatment } \\
\text { Code }\end{array}$ & $\begin{array}{l}\text { Tregiment } \\
\text { Description }\end{array}$ & $\begin{array}{l}\text { Rev. } \\
\text { No. }\end{array}$ & $\begin{array}{c}\text { Revision } \\
\text { Date }\end{array}$ & Nuclide & $\begin{array}{l}\text { Qty } \\
\text { (Bq) }\end{array}$ \\
\hline LFYSULFOCO18 & 022 & & 100 & & 03 & O1-JuL2013 & $\sqrt{1-230}$ & Acontes \\
\hline LRYSLLYYON18 & 022 & & 100 & & $\infty$ & $01 \sqrt{h 4} 2003$ & 4,235 & $5025=43$ \\
\hline LRYSUIFYO018 & 022 & & 100 & & 03 & $01 \sqrt{1} 1-2003$ & $10-234$ & 6A00E+04 \\
\hline
\end{tabular}

$\begin{array}{llllll}\text { Package No: } & 03 L 023 & \text { Contact }(\mathrm{mSv} / \mathrm{h}): & 0.0005 & \text { Completed Date: } & 18-\mathrm{Mar}-2003 \\ \text { Container Code: } & 102 & 1 \text { Meter }(\mathrm{mSWh}): & 0.0005 & \text { Operation Type: } & \text { B } \\ \text { External Volume }\left(\mathrm{m}^{\wedge} 3\right) & 2.265 E-01 & \text { Gross Weight }(\mathrm{kg}): & 3.080 E+02 & \text { Total Activity (bq): } & 5.985 E+05 \\ \text { Waste Volume }\left(\mathrm{m}^{\wedge} 3\right): & 1.980 E-01 & \text { Net Weight }(\mathrm{kg}): & 2.850 E+02 & \text { Activity Date: } & 07-A u g-2003\end{array}$

Comment:

\begin{tabular}{|c|c|c|c|c|c|c|c|c|}
\hline $\begin{array}{c}\text { Waste Stream } \\
\text { Profile }\end{array}$ & $\begin{array}{l}\text { Form } \\
\text { Code }\end{array}$ & $\begin{array}{c}\text { Form } \\
\text { Description }\end{array}$ & $\begin{array}{c}\text { Treatment } \\
\text { Code }\end{array}$ & $\begin{array}{l}\text { Treatment } \\
\text { Description }\end{array}$ & $\begin{array}{l}\text { Rev. } \\
\text { No. } \\
\end{array}$ & $\begin{array}{c}\text { Revision } \\
\text { Date }\end{array}$ & Nuclide & $\begin{array}{l}\text { Qty } \\
\text { (Bq) }\end{array}$ \\
\hline LRYSUFYOCOA8 & 022 & & 100 & & 03 & $01 \sqrt{u}-2003$ & U-238 & $5200 E+05$ \\
\hline LRYSLLY00018 & 022 & & 100 & & 03 & $04 \sqrt{u}$ uk2003 & U-235 & C500E+03 \\
\hline LRYSLLY00018 & 022 & & 100 & & 03 & 어 Ju1-2003 & $0-234$ & $7.200 \leq+04$ \\
\hline
\end{tabular}

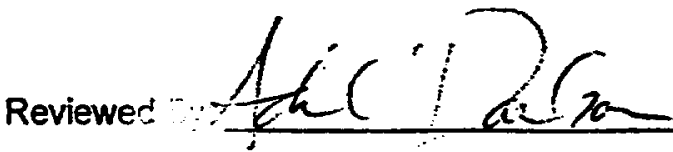




\section{Package Storage and Disposal Request}

Shhipment Number. DPL03015

Date: $10-\operatorname{Sep}-2003$

Prepared By.

Manifest Number:

$\begin{array}{llllll}\text { Package No: } & 03 L 024 & \text { Contact }(\mathrm{mSv} / \mathrm{h}): & 0.0005 & \text { Completed Date: } & \text { 18-Mar-2003 } \\ \text { Container Code: } & 102 & 1 \text { Meter }(\mathrm{mSv} / \mathrm{h}): & 0.0005 & \text { Operation Type: } & \text { B } \\ \text { External Volume }\left(\mathrm{m}^{\wedge} 3\right) & 2.265 E-01 & \text { Gross Weight }(\mathrm{kg}): & 2.810 E+02 & \text { Total Activity }(\mathrm{bq}): & \text { 5.409E+05 } \\ \text { Waste Volume }\left(\mathrm{m}^{\wedge} 3\right): & 1.980 E-01 & \text { Net Weight }(\mathrm{kg}): & 2.580 E+02 & \text { Activity Date: } & \text { 07-Aug-2003 } \\ \text { Comment: } & & & & & \end{array}$

\begin{tabular}{|c|c|c|c|c|c|c|c|c|}
\hline $\begin{array}{c}\text { Waste Stream } \\
\text { Profile } \\
\end{array}$ & \begin{tabular}{|l|} 
Form \\
Code
\end{tabular} & $\begin{array}{c}\text { Form } \\
\text { Description }\end{array}$ & $\begin{array}{c}\begin{array}{c}\text { Treatment } \\
\text { Code }\end{array} \\
\end{array}$ & $\begin{array}{l}\text { Treatment } \\
\text { Description }\end{array}$ & $\begin{array}{l}\text { Rev. } \\
\text { No. } \\
\end{array}$ & $\begin{array}{c}\begin{array}{c}\text { Revision } \\
\text { Date }\end{array} \\
\end{array}$ & Nuclide & $\begin{array}{l}\text { Qty } \\
\text { (Bq) }\end{array}$ \\
\hline LRYSLIFY00018 & 022 & & 100 & & 03 & 01-Jul2003 & $\mathrm{U}-238$ & 4.700E+05 \\
\hline LRYSUFY00018 & 022 & & 100 & & 03 & $04-\sqrt{2}+2003$ & 10235 & 5.900E+03 \\
\hline LRYSUFYOOOT8 & 022 & & 100 & & 03 & $01 \sqrt{c}+2003$ & U-234 & $6.500 E+04$ \\
\hline
\end{tabular}

Package No:

Container Code:

External Volume (m^3) 2.265E-01

Waste Volume (m^3): 1.980E-01 Comment:

\begin{abstract}
Contact (mSv/h):
1 Meter (mSv/h):

0.0005

0.0005

Gross Weight (kg):

Net Welght (kg):

$2.630 \mathrm{E}+02$

$2.400 E+02$
\end{abstract}

Completed Date:

Operation Type:

Total Actlvity (bq):

Activity Date:
18-Nar-2003

B

5.055E +05

07-Aug-2003

\begin{tabular}{|c|c|c|c|c|c|c|c|c|}
\hline $\begin{array}{c}\text { Waste Stream } \\
\text { Profile }\end{array}$ & $\begin{array}{l}\text { Form } \\
\text { Code }\end{array}$ & $\begin{array}{c}\text { Form } \\
\text { Description } \\
\end{array}$ & $\begin{array}{c}\text { Treatment } \\
\text { Code }\end{array}$ & $\begin{array}{l}\text { Treatment } \\
\text { Description }\end{array}$ & $\begin{array}{l}\text { Rev. } \\
\text { No. }\end{array}$ & $\begin{array}{c}\text { Revision } \\
\text { Date }\end{array}$ & Nuclide & $\begin{array}{l}\text { Qty } \\
\text { (Bq) }\end{array}$ \\
\hline LRYSUFY00018 & 02 & & 100 & & 03 & $01-\sqrt{1}-20103$ & 14238 & 4000E+09 \\
\hline LRYSLLYC0018 & 022 & & 100 & & 03 & $01 \sqrt{u}-2003$ & $0-235$ & $5500 E+43$ \\
\hline LRYSLLFY0018 & 022 & & 100 & & 03 & $01 \sqrt{u}+2003$ & U.234 & 6.000E+04 \\
\hline
\end{tabular}

Package No: $\quad 110884$

Container Code: $\quad 210$

Extemal Volume (m^3) 2.920E+00

Waste Volume (m^3): $2.550 E+00$

comment:
Contact (mSv/h):

1 Meter (mSv/h):

Gross Weight (kg):

Net Weight (kg):
0.0005

0.0005

3.579E+03

3.171E+03
Completed Date:

Operation Type:

Total Activity (bq):

Activity Date:
18-Mar-2003

B

7.513E+06

06-Aug-2003

\begin{tabular}{|c|c|c|c|c|c|c|c|c|}
\hline $\begin{array}{c}\text { Weste Stream } \\
\text { Profile } \\
\end{array}$ & $\begin{array}{l}\text { Form } \\
\text { Code }\end{array}$ & $\begin{array}{c}\text { Form } \\
\text { Description }\end{array}$ & \begin{tabular}{|c|} 
Treatment \\
Code
\end{tabular} & $\begin{array}{l}\text { Treatment } \\
\text { Description }\end{array}$ & $\begin{array}{l}\text { Rev. } \\
\text { No. }\end{array}$ & $\begin{array}{c}\text { Revision } \\
\text { Date }\end{array}$ & Nuclide & $\begin{array}{l}\text { Cty } \\
\text { (Bq) }\end{array}$ \\
\hline LRYSULYYCO018 & 022 & & 100 & & 03 & 01-Jut2003 & $0-238$ & CFaE+6s \\
\hline LRYSLIFYOCOTB & 022 & & 100 & & $\mathbf{0 3}$ & O1- & 4.235 & $73905+04$ \\
\hline LRYSLIFYOCOI8 & 022 & & 100 & & 10 & 91Jut2003 & U-234 & 2A00E+05 \\
\hline
\end{tabular}

Package No:

Container Code:

110889

210

External Volume (m^3) 2.920E+00

Waste Volume ( $\left.m^{n} 3\right): \quad 2.550 E+00$ Comment:
Contact (mSv/h): $\quad 0.0005$

1 Meter (mSv/h): $\quad 0.0005$

Gross Weight (kg): $\quad 3.856 E+03$

Net Weight (kg): $\quad 3.447 E+03$
Completed Date:

Operation Type:

Total Activity (bq):

Activity Date:
19-Mar-2003

B

$1.063 E+07$

06-Aug-2003

\begin{tabular}{|c|c|c|c|c|c|c|c|c|}
\hline $\begin{array}{c}\text { Waste Stream } \\
\text { Profile }\end{array}$ & $\begin{array}{l}\text { Form } \\
\text { Code }\end{array}$ & $\begin{array}{c}\text { Form } \\
\text { Description }\end{array}$ & $\begin{array}{c}\text { Treatment } \\
\text { Code }\end{array}$ & $\begin{array}{l}\text { Treatment } \\
\text { Description }\end{array}$ & $\begin{array}{l}\text { Rev. } \\
\text { No. }\end{array}$ & $\begin{array}{c}\text { Revision } \\
\text { Date }\end{array}$ & Nuclide & $\begin{array}{l}\text { Qty } \\
\text { (Bq) }\end{array}$ \\
\hline LRYSUFY00018 & 022 & & 100 & & $\mathbf{0 3}$ & $01 \sqrt{u}+2013$ & $0-238$ & $23005+09$ \\
\hline LRYSLIFY00018 & 022 & & 100 & & $\boldsymbol{\infty}$ & $01 \sqrt{u}-2003$ & $1-235$ & $13005+05$ \\
\hline LRY5LLFY00018 & 022 & . & 100 & & 03 & $01 \sqrt{u 1-2003}$ & U-234 & $1.200 E+06$ \\
\hline
\end{tabular}

Reviewed By: 


\section{Package Storage and Disposal Request}

Shipment Number. DPL03015

Date: 10-Sep-2003
Prepared By.

Manifest Number.

$\begin{array}{llllll}\text { Package No: } & 110890 & \text { Contact }(\mathrm{mSv} / \mathrm{h}): & 0.0005 & \text { Completed Date: } & 18-M a r-2003 \\ \text { Container Code: } & 210 & 1 \text { Meter }(\mathrm{mSv} / \mathrm{h}): & 0.0005 & \text { Operation Type: } & \text { B } \\ \text { External Volume }\left(\mathrm{m}^{\wedge} 3\right) & 2.920 \mathrm{E}+00 & \text { Gross Weight }(\mathrm{kg}): & 3.583 E+03 & \text { Total Activity (bq): } & 9.750 E+06 \\ \text { Waste Volume }\left(\mathrm{m}^{\wedge} 3\right): & 2.550 E+00 & \text { Net Weight }(\mathrm{kg}): & 3.175 E+03 & \text { Activity Date: } & 06-A u g-2003\end{array}$

Comment:

\begin{tabular}{|c|c|c|c|c|c|c|c|c|}
\hline $\begin{array}{c}\text { Waste Stream } \\
\text { Profile }\end{array}$ & $\begin{array}{l}\text { Form } \\
\text { Code }\end{array}$ & $\begin{array}{c}\text { Form } \\
\text { Description }\end{array}$ & \begin{tabular}{|c|}
$\begin{array}{c}\text { Treatment } \\
\text { Code }\end{array}$ \\
\end{tabular} & $\begin{array}{l}\text { Treatment } \\
\text { Description }\end{array}$ & $\begin{array}{l}\text { Rev. } \\
\text { No. }\end{array}$ & $\begin{array}{c}\text { Revision } \\
\text { Date }\end{array}$ & Nuclide & $\begin{array}{l}\mathbf{Q}_{\mathbf{b y}} \\
(\mathrm{Bq})\end{array}$ \\
\hline LRYSLFY00018 & 022 & & 100 & & 03 & $01 \sqrt{u}-2603$ & L-238 & 2500E+06 \\
\hline LRYSLIFYOOA18 & 022 & & 100 & & $\mathbf{0 3}$ & $01 \sqrt{t} 1-2003$ & U-235 & 1.500E+05 \\
\hline LRYSULCFO0018 & 022 & & 100 & & $\mathbf{0 3}$ & O1-Jut-2013 & $4-234$ & $1.160 \mathrm{E}+106$ \\
\hline
\end{tabular}

$\begin{array}{ll}\text { Package No: } & : \begin{array}{l}110940 \\ \text { Container Code: }\end{array} \\ 210\end{array}$

External Volume $\left(m^{\wedge} 3\right) \quad 2.920 E+00$

Waste Vohume $\left(\mathrm{m}^{\wedge} 3\right)$ : $2.550 E+00$ Comment:
Contact (mSv/h):

1 Meter (mSv/h):

Gross Weight (kg):

Net Weight (kg):
0.0005

0.0005

3.915E+03

$3.506 \mathrm{E}+03$

\section{Completed Date:}

Operation Type:

Total Activity (bq):

Activity Date: 19-4lar-2003

B

1.266E+07

08-Aug-2003

\begin{tabular}{|c|c|c|c|c|c|c|c|c|}
\hline $\begin{array}{c}\text { Waste Stream } \\
\text { Profile } \\
\end{array}$ & $\begin{array}{l}\text { Form } \\
\text { Code }\end{array}$ & $\begin{array}{c}\text { Form } \\
\text { Description }\end{array}$ & $\begin{array}{c}\text { Treatment } \\
\text { Code }\end{array}$ & $\begin{array}{l}\text { Treatment } \\
\text { Description }\end{array}$ & $\begin{array}{l}\text { Rev. } \\
\text { No. }\end{array}$ & $\begin{array}{c}\text { Revision } \\
\text { Date }\end{array}$ & Nuctide & $\begin{array}{l}\text { Qty } \\
\text { (Bq) }\end{array}$ \\
\hline LRYSUFYCWOS & 022 & & 100 & · & 03 & 01-Juf-2003 & $1-233$ & $1.100=407$ \\
\hline LRYSULY00018 & 022 & & 100 & & $\mathbf{0 3}$ & 01-Jul-2003 & U-235 & 1.001Etas \\
\hline LRYSULYOCOT8 & 022 & $\bar{r}$ & 100 & & 03 & 01-Jit22003 & U.234 & 1500E+46 \\
\hline
\end{tabular}

Package No: $\quad 110947$

Container Code: $\quad 210$

External Volume $\left(\mathrm{m}^{\wedge} 3\right) \quad 2.920 E+00$

Waste Volume $\left(\mathrm{m}^{\mathrm{i}} 3\right): \quad 2.550 \mathrm{E}+00$ Comment
Contact (mSv/h): $\quad 0.0005$

1 Meter (mSw/h):

Gross Weight (kg):

Net Weight (kg):
0.0005

$3.842 E+03$

3.434E+03
Completed Date:

Operation Type:

Total Activity (bq):

Activity Date: 19-1lar-2003

B

2.840E+07

06-Aug-2003

\begin{tabular}{|c|c|c|c|c|c|c|c|c|}
\hline $\begin{array}{c}\text { Waste Stream } \\
\text { Profile }\end{array}$ & $\begin{array}{l}\text { Form } \\
\text { Code }\end{array}$ & $\begin{array}{c}\text { Form } \\
\text { Description }\end{array}$ & \begin{tabular}{|c|}
$\begin{array}{c}\text { Treatment } \\
\text { Code }\end{array}$ \\
\end{tabular} & $\begin{array}{l}\text { Treatment } \\
\text { Description }\end{array}$ & $\begin{array}{l}\text { Rev. } \\
\text { No. }\end{array}$ & $\begin{array}{c}\text { Revision } \\
\text { Date }\end{array}$ & Nuclide & $\begin{array}{l}\text { Qty } \\
(\mathrm{Bq}) \\
\end{array}$ \\
\hline LRYSUIFYCOAS & 002 & & 100 & & 03 & 01-Jut2003 & $0-228$ & $2500 \leq+07$ \\
\hline LRYSUFY00018 & 022 & & 100 & & 03 & $04 \sqrt{4}-2003$ & $0-235$ & $30 \mathrm{cos}+0 \mathrm{~s}$ \\
\hline LRYSUFY00018 & 022 & & 100 & & 8 & $01 \sqrt{2}+2003$ & $1-231$ & $3.100=+68$ \\
\hline
\end{tabular}

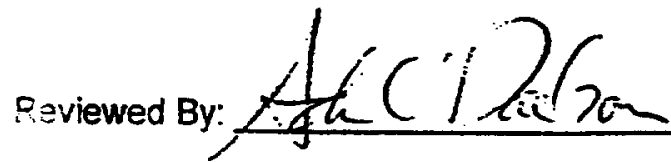




\section{Certificate of Disposal}

This is to certify that the, Waste Stream No., LRY5-LLFY00018 package numbers $110884,110889,110890,110940,110947,03 L 020,03 L 021,03 L 022,03 L 023,03 L 024,03 L 025$ were shipped and received at the Nevada Test Site Radioactive Waste Management Site in Area 5 for disposal as stated below.

Stefan Duke

Shipped by

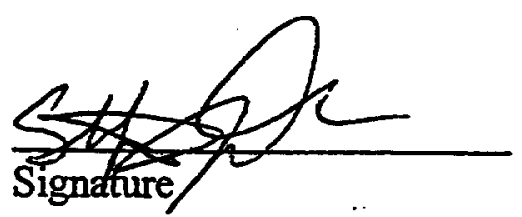

Trenl Selwastzolted

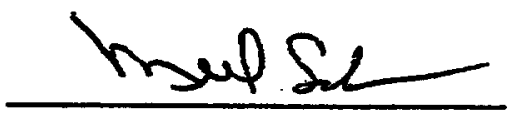

Signature
Bechtel Nevada Waste Generator Services

Organization
Scientist
$8-22-03$

Date

BN

Organization
Tow Staf

Title
Title
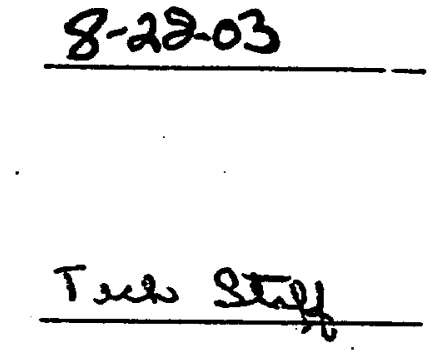

Date

\section{$8 \cdot 28.03$}


Carrier No.

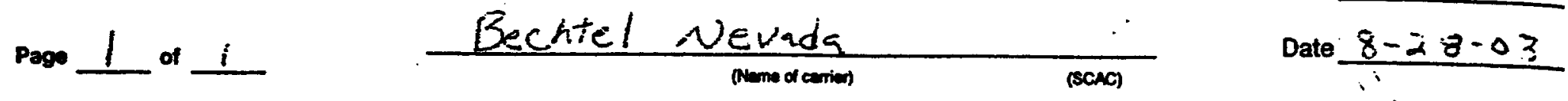

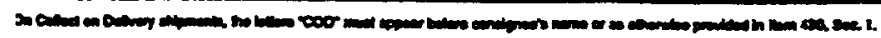

ro: Rechitel puevinds for $125 \mathrm{DO}$ smaREA 5 Rvims plevada test site xy flenciny state Nir zocode 89023

show Bechitel Nevada for US DOC srom Buver II Site TTR

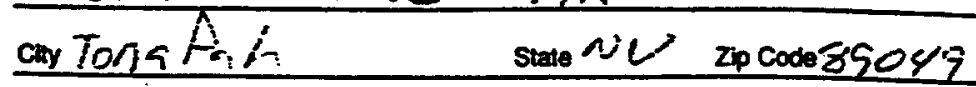

tom

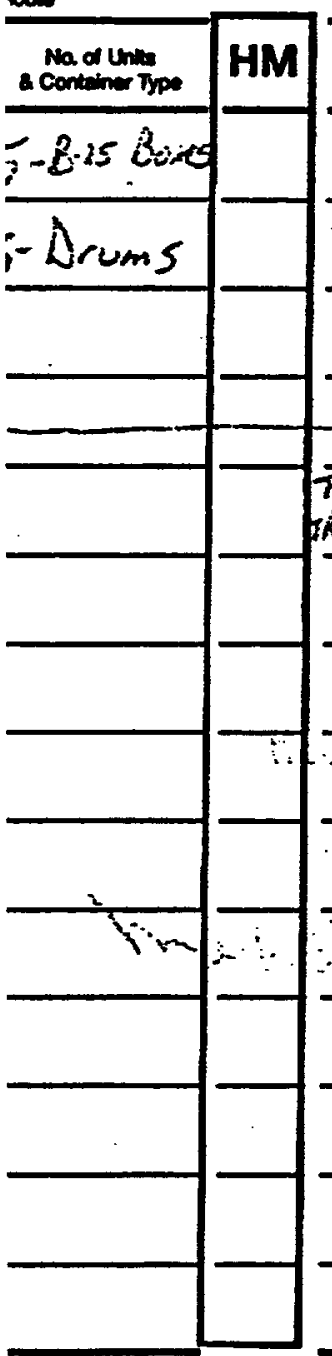

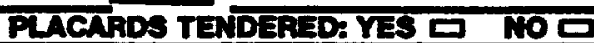

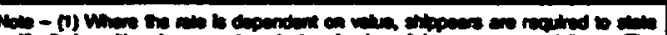

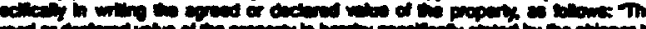

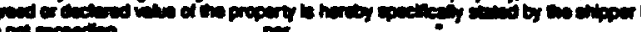

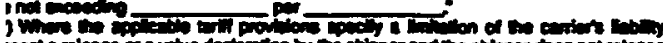

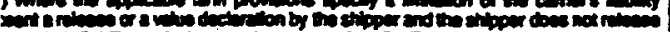

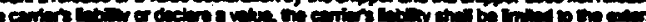

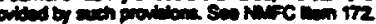

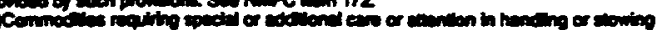

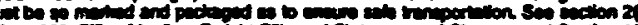
-

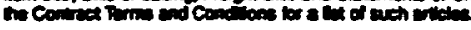

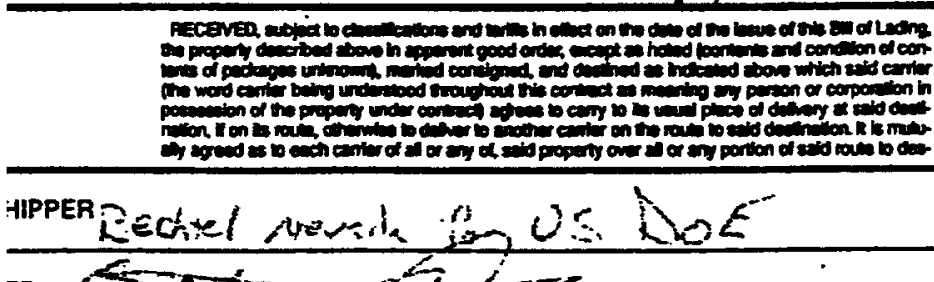

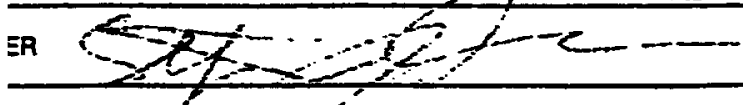

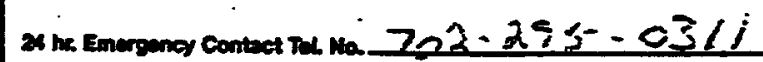

\section{Pry}

(a) Nunide

\section{Base oxcaptow}

Proper Shiping Neme, Hoed Clase.

$101,172202,172.203$

Total

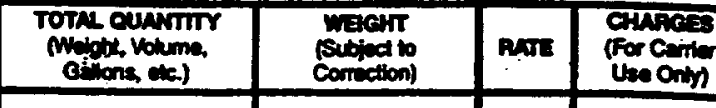

41447 is.

368216.

4512916. 


\section{HAZTRAK ENTRY CONFIRMATION}

Off-Sita Shlpment (From TTR at NEVADA to NTS at NEVADA)

Tracklng No: DPL03016

CarTier. GOVERNMENT TRUCK

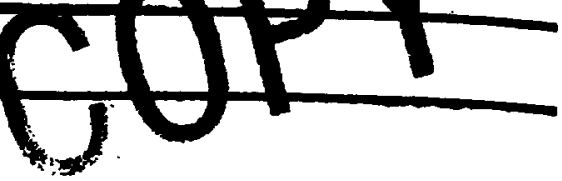

Depart 24-55P-2003 09:00

Threshold: 245EP-2003 09:15
Arival: 24-SEP-2003 13:15

Threshold: 24-SEP-2003 13:15

TO: SHANNON PARSONS-DEPRY

BECHTEL NEVADA

BASE CAMP

MERCURY, NV 89023

Area: 03

Bldg: 3 C38 (AHAT)

Phone: 702-295-7211

Pager.

Date Modified: $\quad$ 16-SEP-2003

Entorad By: DUKESJ

\begin{tabular}{|c|c|c|c|c|}
\hline Shipped Material(s) & Package(s) & Unit(s) & UNMEA & Guide Na. \\
\hline $\begin{array}{l}\text { WASTE } \\
\text { NON-REGULATED WASTE }\end{array}$ & 2 SUPER SACKYST & 33100.00 POUND(S) (GROSS) & - & \\
\hline
\end{tabular}

\section{Hr Emergency Response Number 702-295-0311}


OFF-SITE

\section{$\because \quad$ SHIP FROM}

BECHTEL NEVADA FOR USDOE

TONAPAH TEST RANGE

BECHTEL OFFICE

BASE CAMP

TONAPAH, NV 89049, USA

ADAM DAEGORN at 702/295-7365

\section{SHIPMENT INFORMATION}

REASON: GENERAL MOVEMENT

REQUIRED AT DESTINATION: 09/24/2003

CHARGES: PREPAID

CARRIER: GOVERNMENT TRUCK

PIECE(S): 2 WEIGHT: 33,100 LBS

SHIP DATE: 09/24/2003 ARRIVAL DATE: 09/24/2003

CHARGEJORG NO: 5B03KB3O/A510
9/16/2003

SHIP TO

BECHTEL NEVADA FOR USDOE

NEVADA TEST SITE

RECEMING WAREHOUSE 160

MERCURY, NV 89023, USA

SHANNON PARSONS-DEPRY at 702/295-2799

REFERENCE NO.: N/A

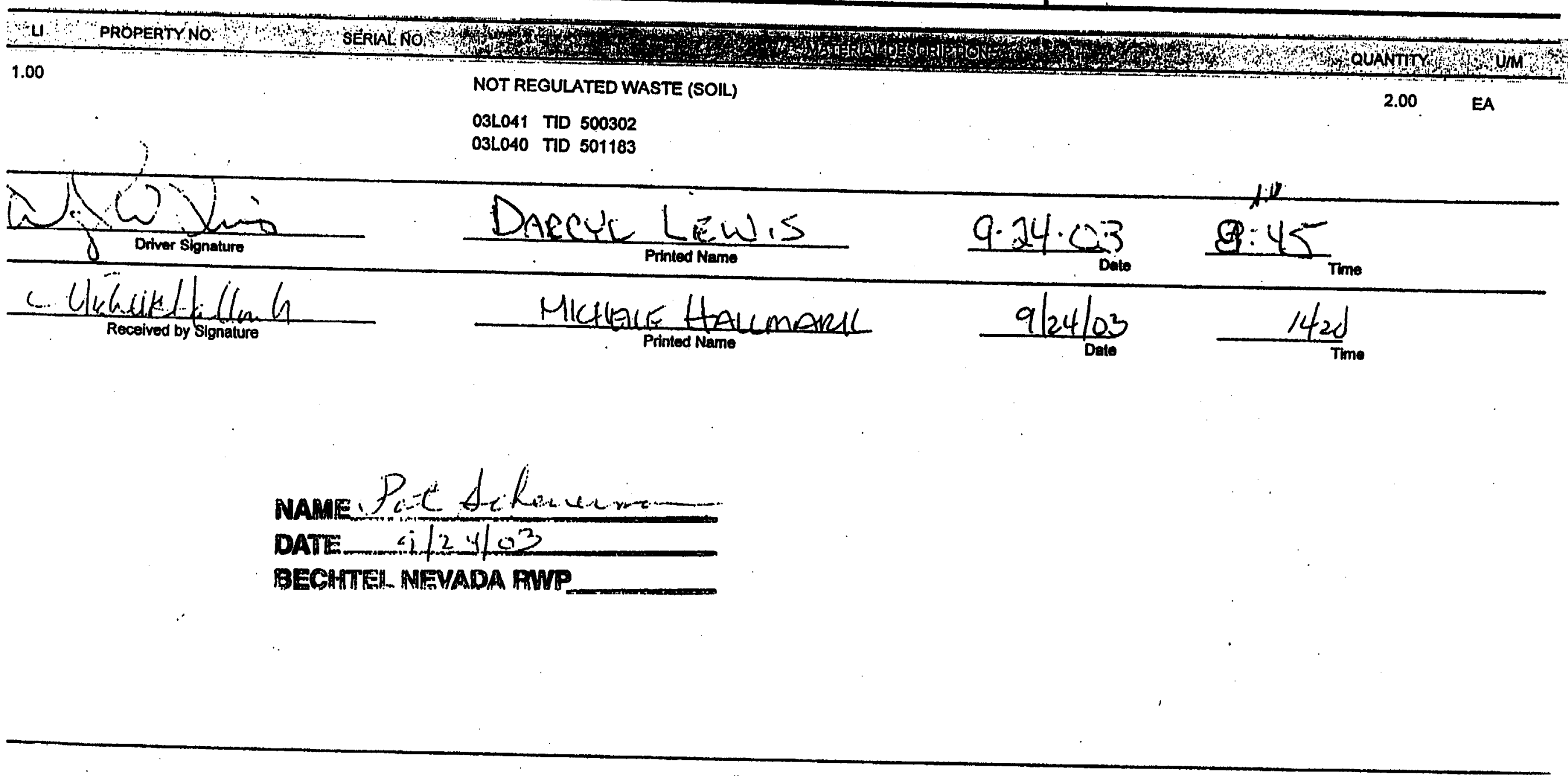




\section{Package Storage and Disposal Request}

Shipment Number: DPL03016

Date: 08-Sep-2003

Prepared By:

Manifest Number.

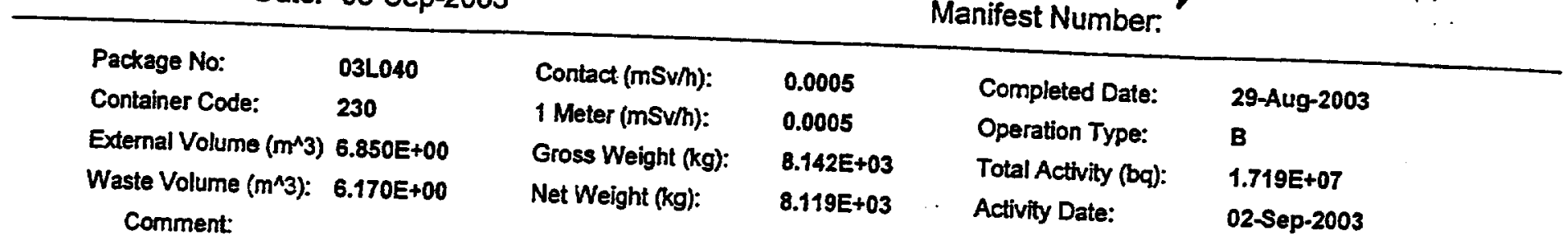

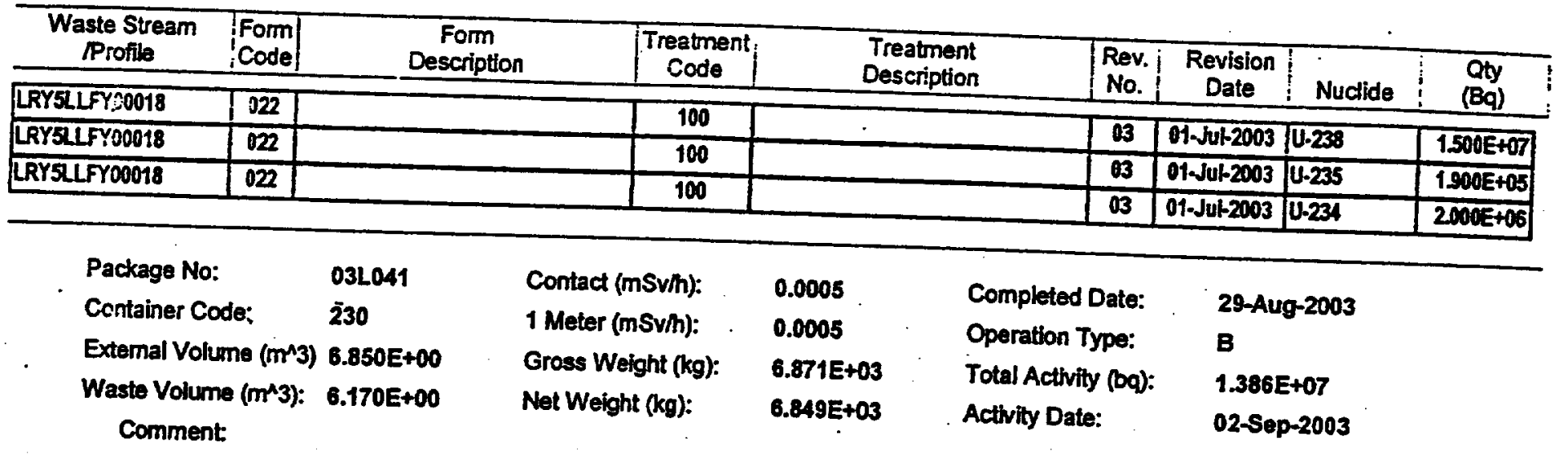

\begin{tabular}{|c|c|c|c|c|c|c|c|c|}
\hline $\begin{array}{c}\begin{array}{c}\text { Waste Stream } \\
\text { Profile }\end{array} \\
\text { LRYSLFYow018 }\end{array}$ & $\begin{array}{l}\text { Form } \\
\text { Code }\end{array}$ & $\begin{array}{c}\text { Form } \\
\text { Description }\end{array}$ & \begin{tabular}{c|} 
Treatment \\
Code
\end{tabular} & $\begin{array}{l}\text { Treatment } \\
\text { Description }\end{array}$ & $\begin{array}{l}\text { Rev. } \\
\text { No. }\end{array}$ & $\begin{array}{c}\text { Revision } \\
\text { Date }\end{array}$ & Nuclide & $\begin{array}{l}\text { Qty } \\
(\mathrm{Bq})\end{array}$ \\
\hline \begin{tabular}{|l|l|l|} 
LRYSLO018 \\
\end{tabular} & $\frac{122}{n 2 m}$ & & 100 & & D3 & $01 \sqrt{u+2003}$ & U-238 & 1.200E+07 \\
\hline LRYSULYOOOA18 & \begin{tabular}{|l|}
022 \\
022 \\
\end{tabular} & & 100 & & 103 & $01 \sqrt{ }{ }^{2}-2003$ & U-235 & 1.600E+05 \\
\hline & & & 100 & & 03 & $01-3 u b 2003$ & U-234 & 1.700E+06 \\
\hline
\end{tabular}




\section{Low-Level Waste Certification}

I certify that containers: $03<040$

$$
03<041
$$

do not contain hazardous waste as defined in Title 40 CFR 261 or state of Nevada hazardous waste regulations: 1. According to the results of test performed in accordance with the requirements as
specified in Subpart C of Title 261 ; and/or

2. According to the supporting documentation provided to me about the materials and processes that produced this waste. To the best of my knowledge, I believe the information I have submitted is true, accurate,
and complete. 


\section{Certificate of Disposal}

This is to certify that the, Waste Stream No., LRY5-LLFY00018 package numbers 03L040 and 031041 were shipped and received at the Nevada Test Site Radioactive Waste Management Site in Area 3 for disposal as stated below.

Steran Duke

Shiped by

Shipped by

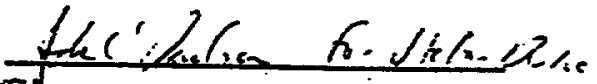
Signature

$\frac{\text { Mrtlale Haumark }}{\text { Received by }}$

Aticiletalih

Signature
Bechtel Nevada Waste Generator Services

Organization
Scientist

Title

Date

$09 / 24 / 0 ?$

Title

Date

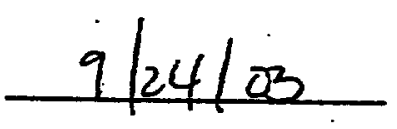




\section{HAZTRAK ENTRY CONFIRMATION}

Oil-Site Shiprrent (From TTR at NEVADA to NTS at NEVADA)

Trekng No: EPLO3017

Cartier. GOVERNMENT TRUCK

Artval: 22-SEP-2003 15:30

Threshold: 22-5EP-2003 15:00
Depat: 22-SEP-2003 10:00

Threshold: 22-SEP-2003 10:15
TO: SHANNON PARSONS-DEPRY

BECHTEL NEVADA

BASE CAMP

MERCURY, NV 89023

Area: 03

Bidg: 3 C36 (AHAT)

Phone: 702-295-7219

Pager.

Entered By: DUKESJ

Date Modlfied: $15-5 E P-2003$

\begin{tabular}{llll}
\hline Shlpped Material(s) & Packago(s) & Unit(s) & UNNA Guide \\
No.
\end{tabular}

RADIOACTIVE MATERULL, LOW SPECIFIC ACTIVTY (LSA-l)

7. UN2912. RADIONUCLIDES:U(DEPLETED) PHYSKCAL FORM:SOLID

CHEMICAL FORM:OXIDE PACKAGE ACTMVIT:305629 $1.22377 \mathrm{BQ}$

CATEGORY:LSAH EXCLUSNE USE SHIPMENT

\section{4-Hr Emergency Response Number 702-295-0311}




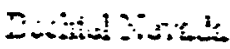

\section{mane of comien}

Carrier No.

$$
\therefore \therefore 3
$$

Date
915?

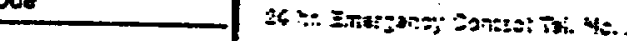

Fonogh Int Finge

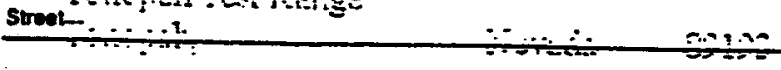

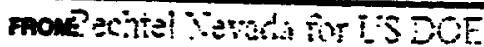

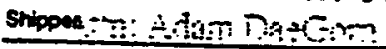

- 1720103

$\therefore$ :

(1)
PLACARDS TENDERED:YES $\square$ NO $\square$

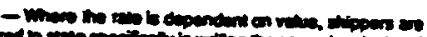

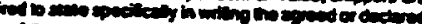

id the propary.

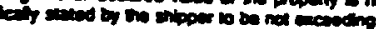

$-\infty$

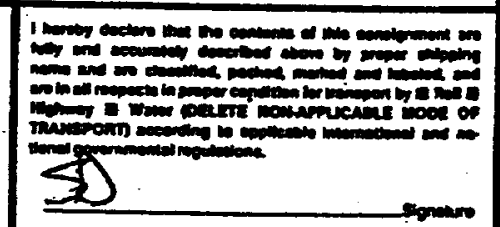

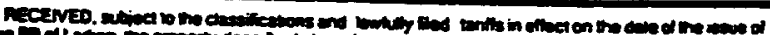

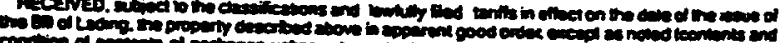

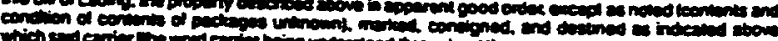

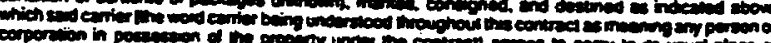

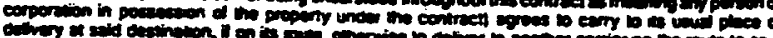

DATE $9 / 22 / 03$ BECHTEL NEVADARWP

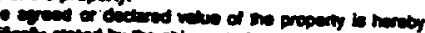

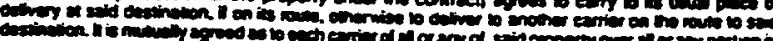

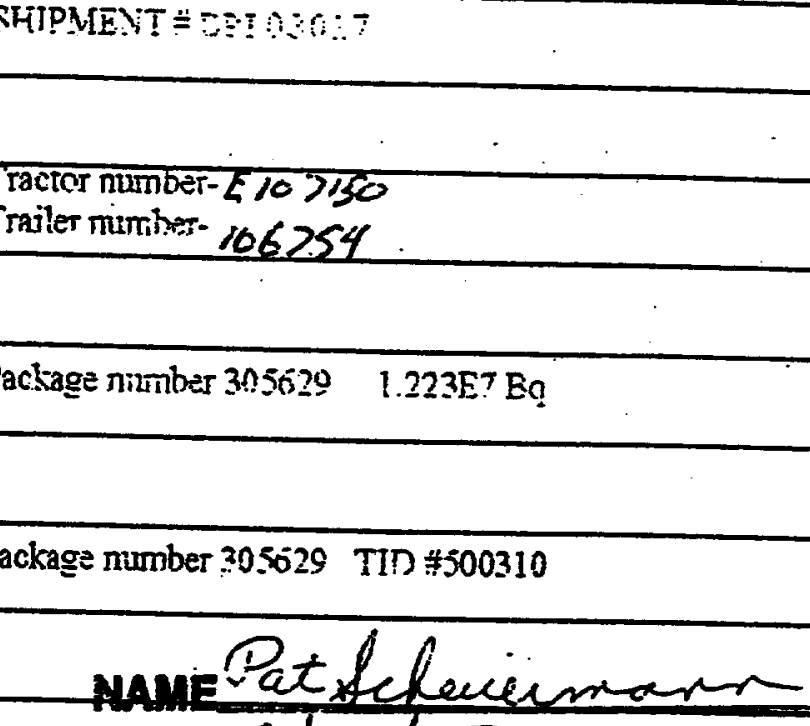

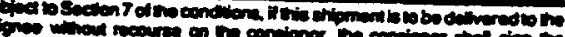

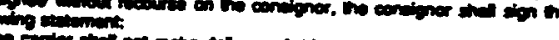

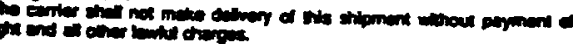

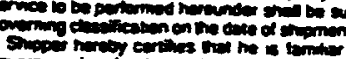

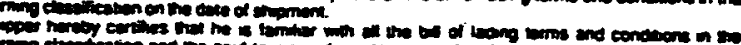

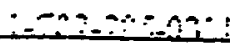

Vende

Menber

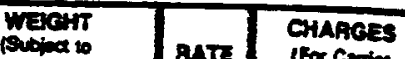
Comection ivisis

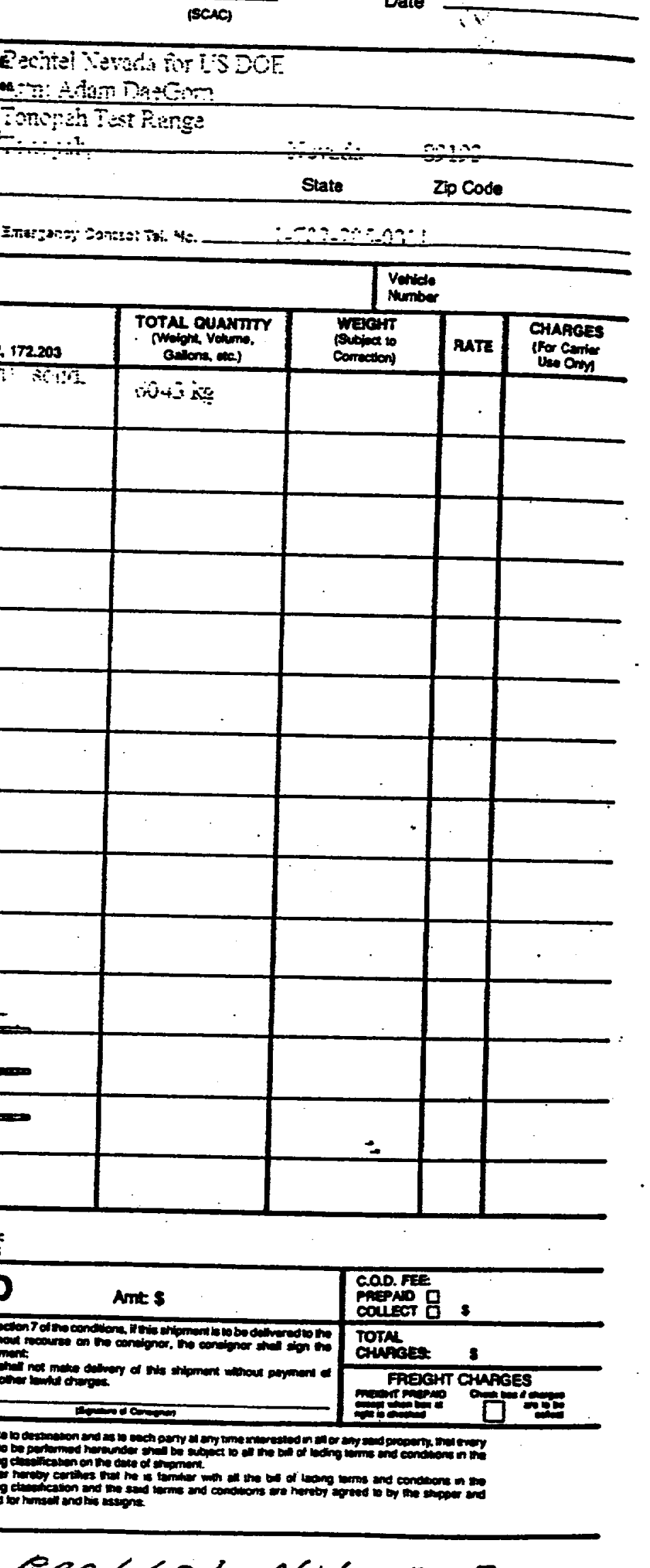

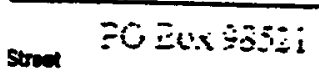

Gity Ios

$\underset{1}{\infty}$

SHIPMENIT $=$

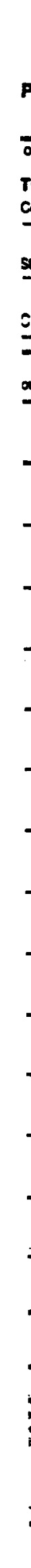

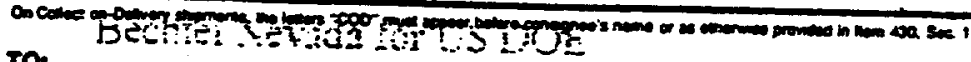

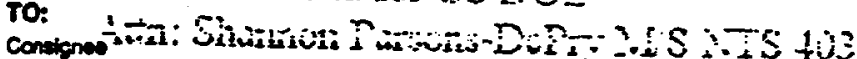
Zip Code

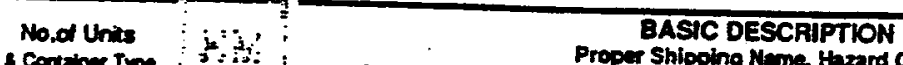

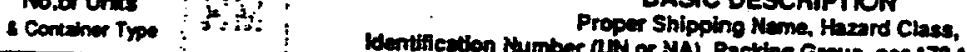

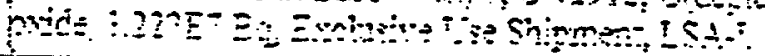

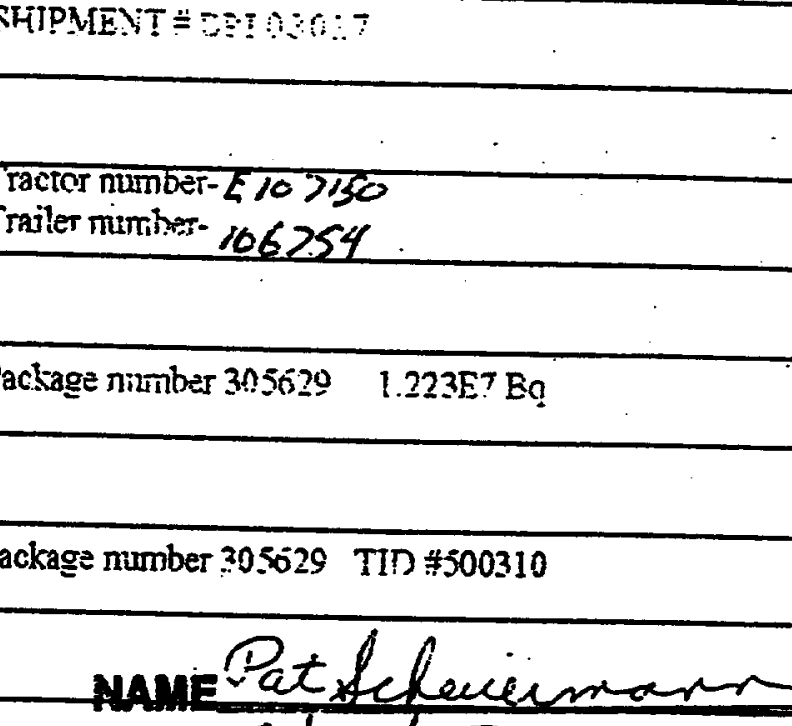

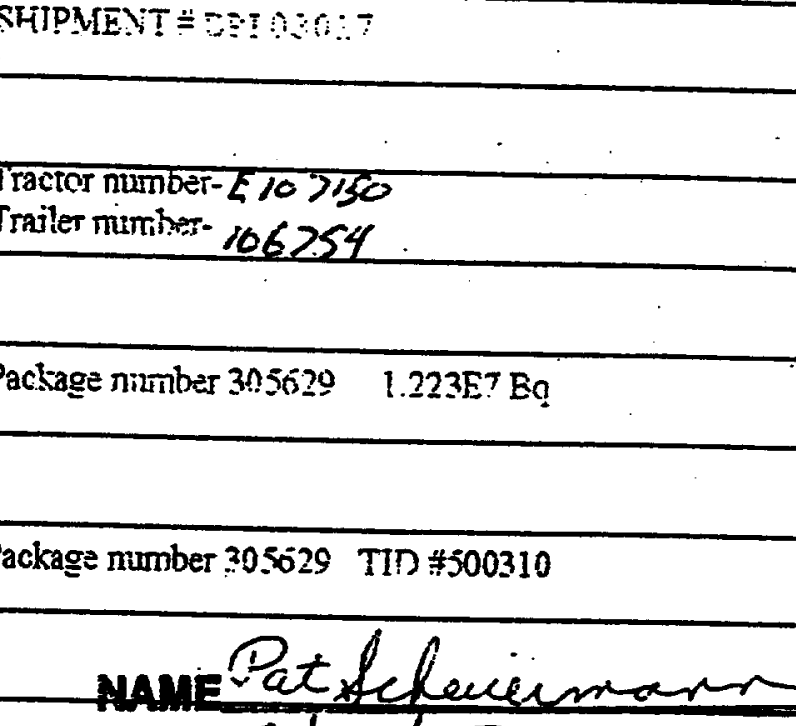

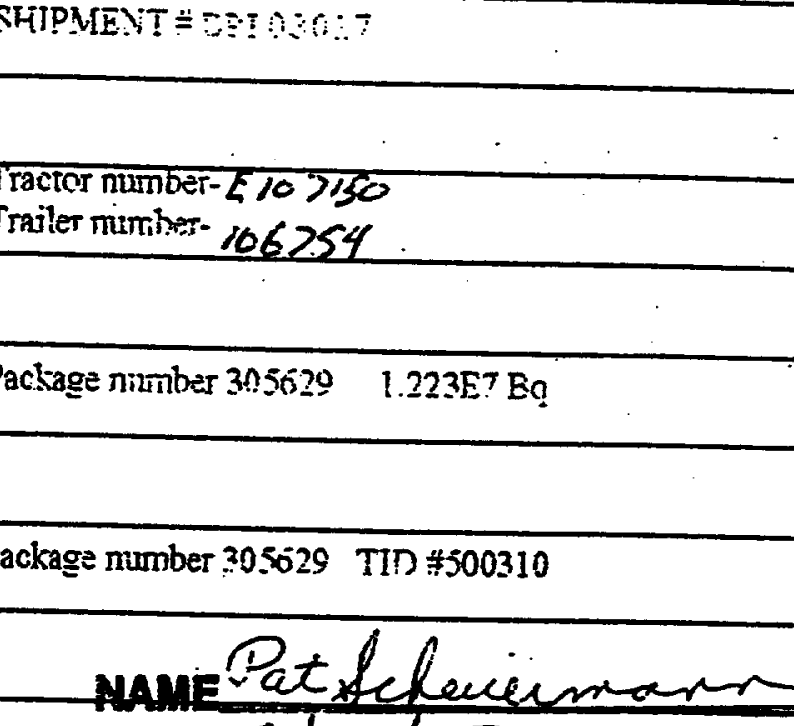

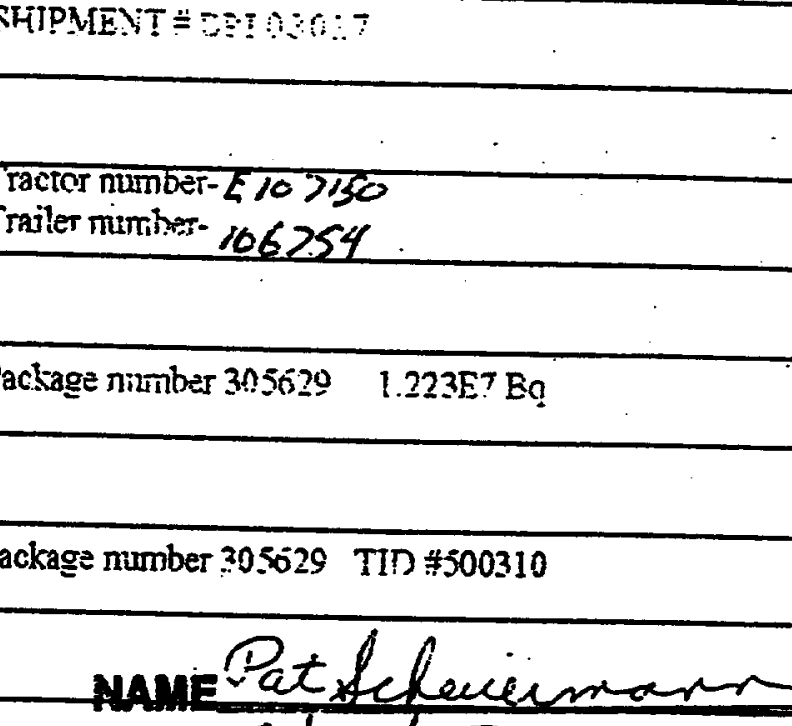

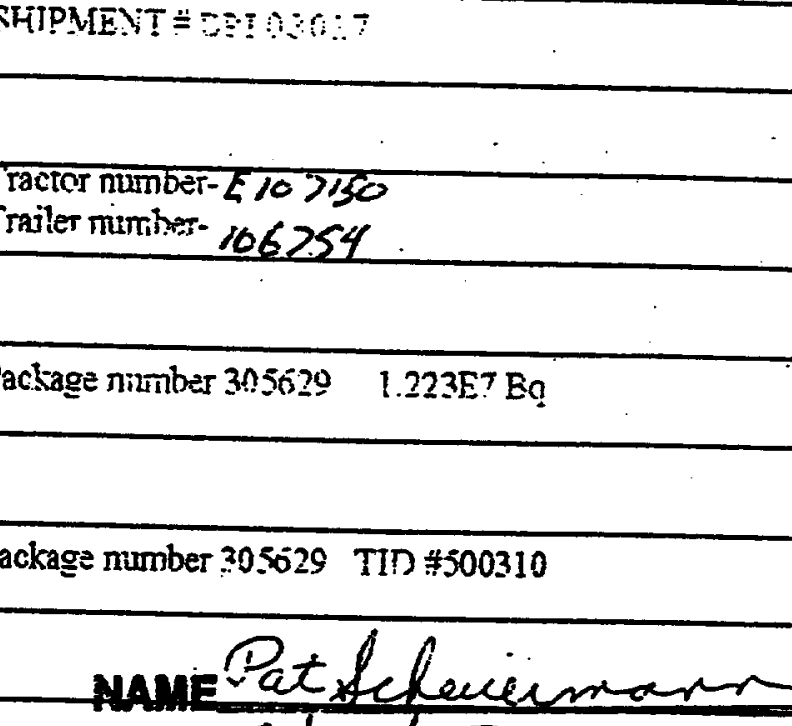

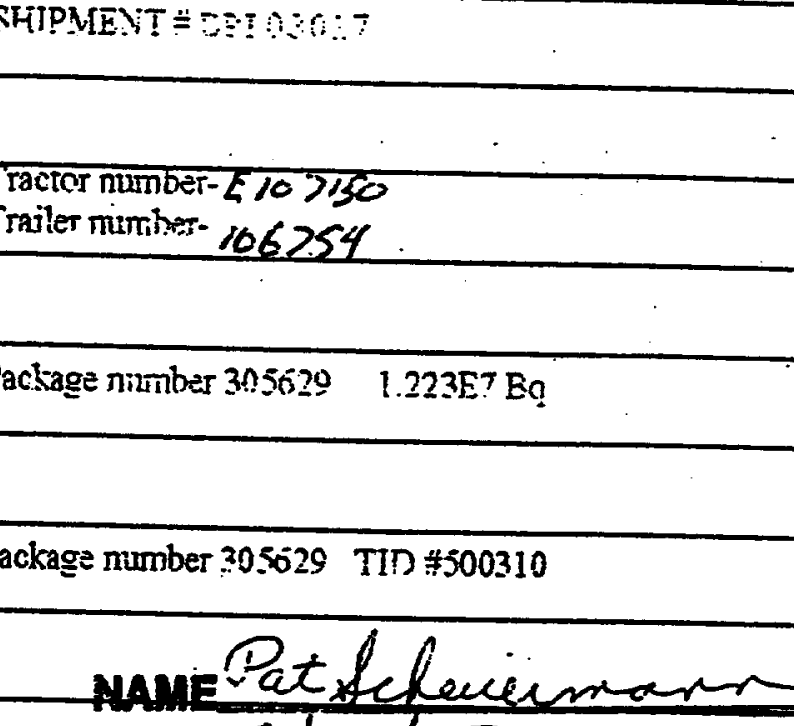

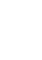

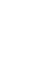




\section{Package Storage and Disposal Request}

Shipment Number. DPL03017

Date: 11 Sep-2003

Prepared By:

Manifest Number.

\begin{tabular}{|c|c|c|c|c|c|}
\hline $\begin{array}{l}\text { Package No: } \\
\text { Container Code: } \\
\text { External Volume }\left(m^{\wedge} 3\right) \\
\text { Waste Volume }\left(m^{\wedge} 3\right) \text { : } \\
\text { Comment: }\end{array}$ & $\begin{array}{l}305629 \\
220 \\
3.600 E+01 \\
2.700 E+01\end{array}$ & $\begin{array}{l}\text { Contact (mSv/h): } \\
1 \text { Meter (mSv/h): } \\
\text { Gross Weight (kg): } \\
\text { Net Weight (kg): }\end{array}$ & $\begin{array}{l}0.0005 \\
0.0005 \\
6.043 E+03 \\
3.673 E+03\end{array}$ & $\begin{array}{l}\text { Completed Date: } \\
\text { Operation Type: } \\
\text { Total Activity (bq): } \\
\text { Activity Date: }\end{array}$ & $\begin{array}{l}02-S e p-2003 \\
\text { B } \\
1.223 E+07 \\
03-S e p-2003\end{array}$ \\
\hline
\end{tabular}

\begin{tabular}{|c|c|c|c|c|c|c|c|c|}
\hline $\begin{array}{c}\begin{array}{c}\text { Waste Stream } \\
\text { /Profile }\end{array} \\
\text { LRY5LLFY00018 }\end{array}$ & $\begin{array}{l}\text { Form } \\
\text { iCode }\end{array}$ & $\begin{array}{c}\text { Form } \\
\text { Description }\end{array}$ & $\begin{array}{l}\text { Treatment: } \\
\text { Code }\end{array}$ & $\begin{array}{c}\text { Treatment } \\
\text { Description }\end{array}$ & $\begin{array}{l}\text { Rev. } \\
\text { No. }\end{array}$ & $\begin{array}{c}\text { Revision } \\
\text { Date }\end{array}$ & Nuclide & $\begin{array}{l}\text { Qty } \\
\text { (Bq) }\end{array}$ \\
\hline LRY5LLFY00018 & 040 & & 100 & & 03 & $01-J u 1-2003$ & U.-238 & 1.071E+07 \\
\hline LRY5LLFY00018 & 040 & & 100 & & 03 & $01 \sqrt{u f 1}-2003$ & U-235 & $1.457 E+05$ \\
\hline & & & 100 & & 03 & $0 y-J u 1-2003$ & U.234 & $1.378 E+06$ \\
\hline
\end{tabular}




$$
A \therefore<=3: 17
$$

\section{Low-Level Waste Certification}

I certify that containers: $30562 \%$

do not contain hazardous waste as defined in Title 40 CFR 261 or state of Nevada hazardous waste regulations:

1. According to the results of test performed in accordance with the requirements as specified in Subpart C of Title 261; and/or

2. According to the supporting documentation provided to me about the materials and processes that produced this waste. To the best of my knowledge, I believe the information I have submitted is true, accurate,
and complete.

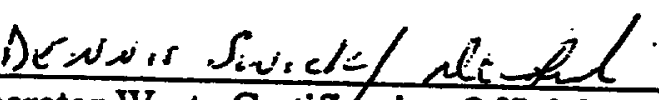

Generator Waste Certification Official (Print Name/Sign) $\frac{s / 2 \cdot 2 / 03}{\text { Date }}$ 
Certificate of Disposal

This is to certify that the, Waste Stream No., LRY5-LLFY00018 package numbers 305629 was shipped and received at the Nevada Test Site Radioactive. Waste Management Site in Area 3 for disposal as stated below.

Stefan Duke

Shipped by
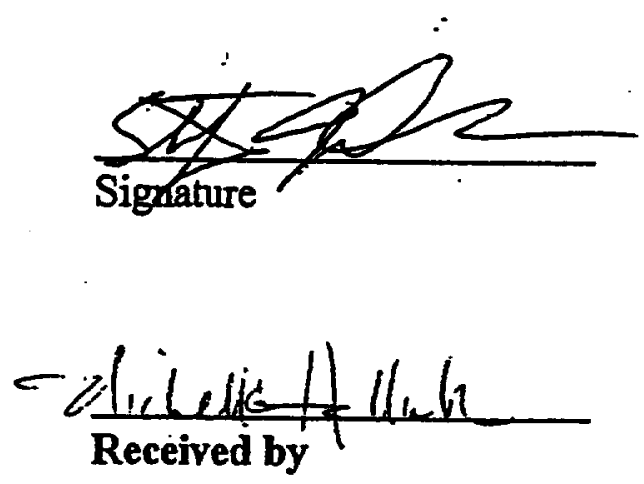

MiCHELE HALLMARK Signature
Bechtel Nevada Waste Generator Services

Organization

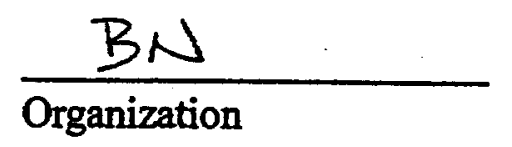

Date

Scientist

Title

Date

$9-22-03$

Title RWMS

9122103 


\section{HAZTRAK ENTRY CONFIRMATION}

Off-Site Shipment (From TIR at NEVADA to NTS at NEVADA)
Tracklng NO: DPLO3018
Carrilir: GOVERNMENT TRUCK

CDL ON FILE $N$

Depart 24SEF-2003 09:00

Thresticld: 24-SEP-2003 09:15
Artival: 24-SEP-2003 13:13

Threshold: 24-SEP-2003 13:15
From: ADAM DAEGORN

BECHTEL NEVADA

TONAPAH

CAU4TO ER STTE

TONAPAH, NV 89049

ArOa: CAUA10

Bldg: ER STIE

Phone: 702-295-4779
TO: SHANNON PARSONS-DEPRY

BECHTEL NEVADA

BASE CAMP

MERCURY, NV 89023

Area: 03

. Bldg: 3 C36 (AHAT)

Phone: 702-295-7211

Pager.

Entered By: DUKESJ

Date Modifed: I6-SEP-2003

\begin{tabular}{|c|c|c|c|c|}
\hline Shipped Materbl(s) & Package(s) & Unit(o) & UNNR & Guido Na. \\
\hline $\begin{array}{l}\text { WASTE } \\
\text { NON-REGULATED WASTE }\end{array}$ & 2 SUPER SACK(S) & 33150.00 POUND(S) (GROSS) & $\longrightarrow$ & - \\
\hline
\end{tabular}

\section{4-Hr Emergency Response Number}

702-295-0311 


\section{SHIP FROM}

:1:CHTEL NEVADA FOR USDOE IONAPAH TEST RANGE BECHTEL OFFICE

BASE CAMP

TONAPAH, NV 89049, USA

ADAM DAEGORN at 702/295-7365

NTS AREA 52 TTR

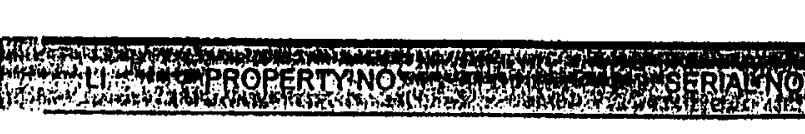

1.00

\section{OFF-SITE SHIPMENT}

REQUIRED AT DESTINATION: 09/24/2003

REASON: GENERAL MOVEMENT

SHIP METHOD: MOVEMENT FROM ORIGINATOR'S LOCATION

CHARGES: PREPAID

ESTIMATED PIECE(S): 2 WEIGHT: 33,150 LBS

CHARGEIORG NO: 5B03KB3O/A510

\section{SHIP TO}

BECHTEL NEVAUA FOR USDOE

NEVADA TEST SITE

RECEIVING WAREHOUSE 160

MERCURY, NV 89023, USA

NTS AREA 3 BLDG: RWMS

SHANNON PARSONS-DEPRY at 702/295-2799

REFERENCE NO.: NA

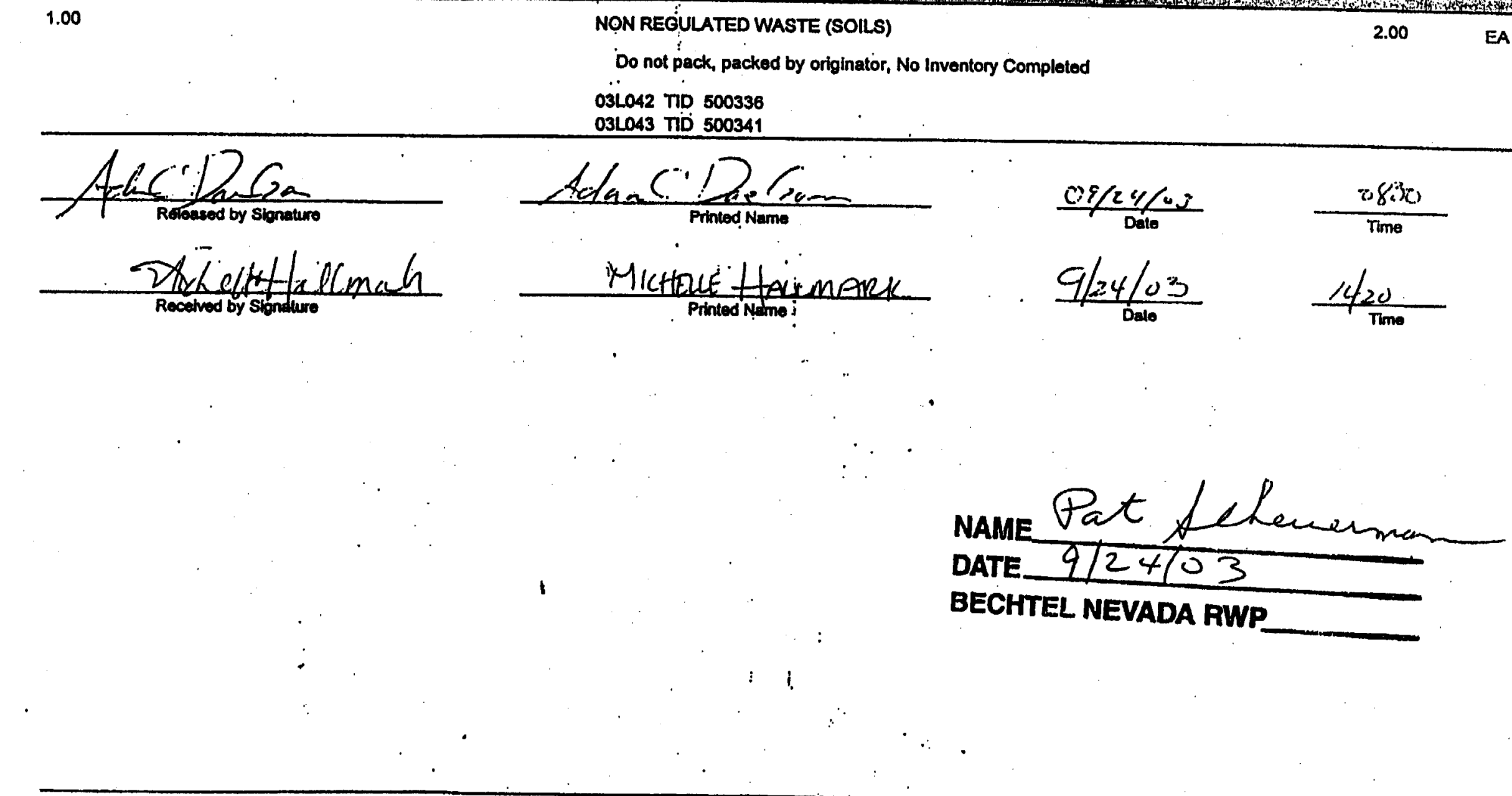




\section{Package Storage and Disposal Request}

Shipment Number: DPL03018

Date: 08-Sep-2003

Prepared By:

Manifest Number:

\begin{tabular}{|c|c|c|c|c|c|}
\hline & -200 & & & iffest Number: & \\
\hline $\begin{array}{l}\text { Package No: } \\
\text { Container Code: } \\
\text { External Volume }\left(m^{\wedge} 3\right) \\
\text { Waste Volume }\left(m^{\wedge} 3\right) \text { : } \\
\text { Comment: }\end{array}$ & $\begin{array}{l}03 L 042 \\
230 \\
6.850 E+00 \\
6.170 E+00\end{array}$ & $\begin{array}{l}\text { Contact (mSv/h): } \\
1 \text { Meter (mSv/h): } \\
\text { Gross Weight (kg): } \\
\text { Net Weight (kg): }\end{array}$ & $\begin{array}{l}0.0005 \\
0.0005 \\
7.552 E+03 \\
7.529 E+03\end{array}$ & $\begin{array}{l}\text { Completed Date: } \\
\text { Operation Type: } \\
\text { Total Activity (bq): } \\
\text { Activity Date: }\end{array}$ & $\begin{array}{l}29-A u g-2003 \\
\text { B } \\
1.607 E+07 \\
02-\text { Sep-2003 }\end{array}$ \\
\hline
\end{tabular}

\begin{tabular}{|c|c|c|c|c|c|c|c|c|c|}
\hline $\begin{array}{c}\begin{array}{c}\text { Waste Stream } \\
\text { Profile }\end{array} \\
\end{array}$ & $\begin{array}{l}\text { Form } \\
\text { Code }\end{array}$ & $\begin{array}{c}\text { Form } \\
\text { Description }\end{array}$ & {$\left[\begin{array}{c}\text { Treatment! } \\
\text { Code }\end{array} \mid\right.$} & \multicolumn{2}{|c|}{$\begin{array}{l}\text { Treatment } \\
\text { Description }\end{array}$} & \begin{tabular}{|c|}
$\begin{array}{l}\text { Rev. } \\
\text { No. }\end{array}$ \\
\end{tabular} & $\begin{array}{c}\begin{array}{c}\text { Revision } \\
\text { Date }\end{array} \\
\end{array}$ & Nuclide & $\begin{array}{l}\text { Qty } \\
\text { (Bq) }\end{array}$ \\
\hline LRYSLLFYO0018 & 022 & & 100 & & & Q3 & $01-\sqrt{u}-2003$ & J.239 & $1.100 E+07$ \\
\hline LRYSLLFYO0018 & 022 & & 100 & & & 03 & $01-\sqrt{u} 4-2003$ & 0.235 & $1.700 E+05$ \\
\hline LRYSUIFYO0018 & 022 & & 100 & & & DB & $01-\mathrm{Ju}+2003$ & $U .234$ & $1.900 E+06$ \\
\hline $\begin{array}{l}\text { Package No } \\
\text { Container C } \\
\text { External Vol } \\
\text { Waste Volus } \\
\text { Commer }\end{array}$ & $\begin{array}{l}\text { de: } \\
\text { me }\left(m^{\wedge} 3\right) \\
\text { e }\left(m^{\wedge} 3\right):\end{array}$ & $\begin{array}{l}03 L 043 \\
230 \\
6.850 E+00 \\
6.170 E+\infty 0\end{array}$ & $\begin{array}{l}\text { Contact (mSv/h): } \\
1 \text { Meter (mSv/h): } \\
\text { Gross Weight (kg): } \\
\text { Net Weight (kg): }\end{array}$ & $\begin{array}{l}0.0005 \\
0.0005 \\
7.507 E+03 \\
7.484 E+03\end{array}$ & & $\begin{array}{l}\text { Date: } \\
\text { Type: } \\
\text { vity (bq): } \\
\text { ate: }\end{array}$ & $\begin{array}{l}29 \text {-Aug } \\
\text { B } \\
1.607 E \\
02-S e p\end{array}$ & $\begin{array}{l}19-2003 \\
E+07 \\
p-2003\end{array}$ & \\
\hline
\end{tabular}

\begin{tabular}{|c|c|c|c|c|c|c|c|c|}
\hline $\begin{array}{c}\text { Waste Stream } \\
\text { Profile }\end{array}$ & \begin{tabular}{|l|} 
Form \\
Code
\end{tabular} & $\begin{array}{c}\text { Form } \\
\text { Description }\end{array}$ & \begin{tabular}{c|}
$\begin{array}{c}\text { Treatment } \\
\text { Code }\end{array}$ \\
\end{tabular} & $\begin{array}{l}\text { Treatrnent } \\
\text { Description }\end{array}$ & $\begin{array}{l}\text { Rev. } \\
\text { No. }\end{array}$ & $\begin{array}{c}\text { Revision } \\
\text { Date }\end{array}$ & Nuclide & $\begin{array}{l}\text { Qty } \\
(\mathrm{Bq})\end{array}$ \\
\hline LRYSLLFY00018 & 022 & & 100 & & 03 & $01 \sqrt{u t 2003}$ & 1-2338 & 1.A0E+07 \\
\hline LRYSIFY00018 & 022 & & 100 & & 03 & $01 \sqrt{u}-2003$ & U-235 & $1.700 E+05$ \\
\hline LRYSLLFY00018 & 0022 & & 100 & & $\overline{03}$ & $01-J u+2003$ & U-234 & $1,900 E+06$ \\
\hline
\end{tabular}

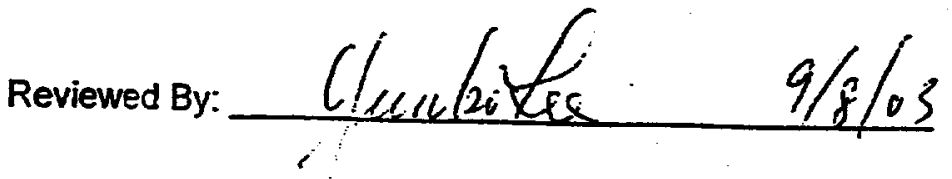




\section{DPCO3018}

I v.Lcvel Waste Certification

: riff that containers: $03\llcorner 042$

OJLOY3 2ut contain hazandous waste as defined in Title 40 CFR 261 or state of Nevada
a dous waste regulations:

1 According to the results of test performed in accordance with the requirements as specified in Subpart C of Title 261; and/or

: Avcording to the supporting documentation provided to me about the materials and processes that produced this waste.

the best of my knowledge, I believe the information I have submitted is true, accurate, romplete.

LEvisis Swiek/ alwal

uralor Waste Certification Official (Print Name/Bign)

$9 / 23 /-3$ 


\section{Certificate of Disposal}

This is to certify that the, Waste Stream No., LRY5-LLFY00018 package numbers 03L042 and 031043 were shipped and received at the Nevada Test Site Radioactive Waste Management Site in Area 3 for disposal as stated below.

Stefan Duke

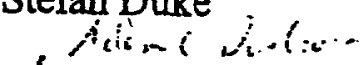

Bechtel Nevada Waste Generator Services

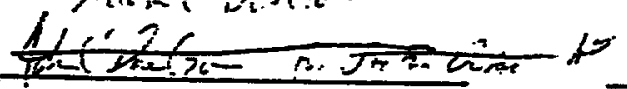

Shipped by

Organization

Scientist

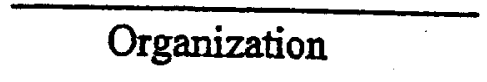

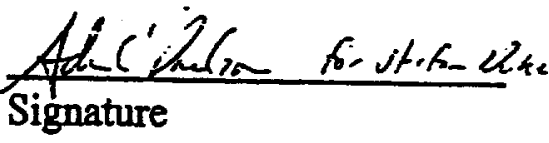

Date $\quad 09 / 25 / 0 j$

Mífelle HaumizeK

Received by

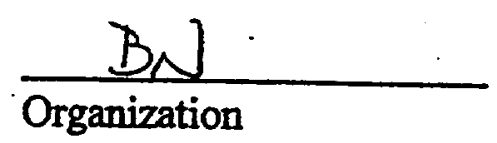

Title

Title

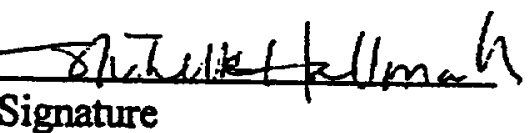

$9 / 24 / 03$

Date 


\section{HAZTRAK ENTRY CONFIRMATION}

\section{Orf-Site Shipment ' (From TTR at NEVADA to NTS at NEVADA)}

Tracking No: DPL03020

Carter: GOVERNMENT TRUCK

CDL: ON FILE NV

\section{Depart. 22-5EP-2003 10:00}

Threshold: 22.SEP-2003 10:15
ATthat: 22-SEP-2003 15:30

Threshold: 22-SEP-2003 15:00
FraT: ADAM DAEGORN BECHTEL NEVADA TONAPAH

CAU410 ER STTE

TONAPAH, NV 89049

Area: CAU410

Blig: ER.SITE

Phone: 702-295-4779
TO: SHANNON PARSONS-DEPRY BECHTEL NEVADA BASE CAMP MERCURY, NV 89023

Area: 03

Bldg: 3 C36 (AHAT)

Phane: 702-295-7211

Pager.

Entered By: DUKESJ Date Nodified: 15-SEP-2003

\section{Shlpped Matertal(s)}

REPORTABLE QUANTITY, WASTE

RADIOACTIVE MATERIAL, LOW SPECIFIC ACTIVITY (LSA-A)

7. UN2912 RADIONUCLIDES:U(DEPLETED PHYSICAL FORM:SOUD CHENICAL

FORM.OXIDE PACKAGE ACTMITY:03LO44 6.9EOBQ, 03L045 7.1EOBQ

\section{4-Hr Emergency Response Number \\ 702-295-0311}

\begin{tabular}{llll} 
Package(s) Uniu(s) & UNNA $\begin{array}{r}\text { Guide } \\
\text { No. }\end{array}$ \\
\hline $\begin{array}{llll}\text { 2 SUPER } \\
\text { SACK(S) }\end{array}$ & $\begin{array}{l}13165.00 \\
\text { KLOGRAM(S) } \\
\text { (GROSS) }\end{array}$ & 2912 & 162 \\
\hline
\end{tabular}


Carrier No.

Page of

Meme of contion

iscac

Date

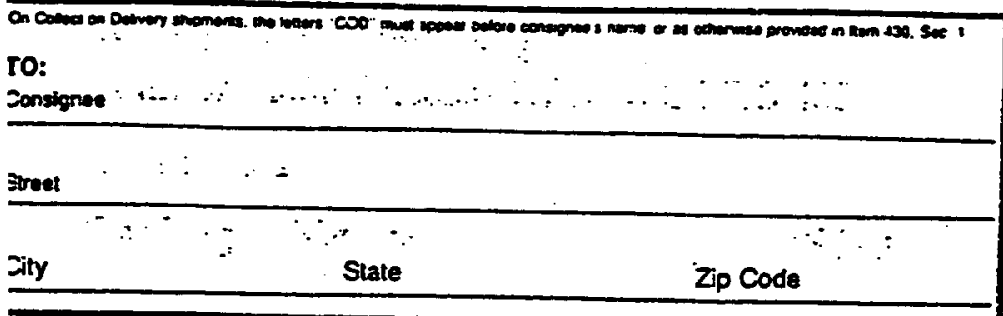

FAOM: $=\because, \because \because, \cdots, \cdots, \cdots \cdot \cdots$

Shipoer $\ldots, \cdots, \cdots, \cdots$

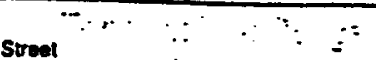

City State Zip Cote

24 is: Emergeney Contact Bal. Hio.

oute

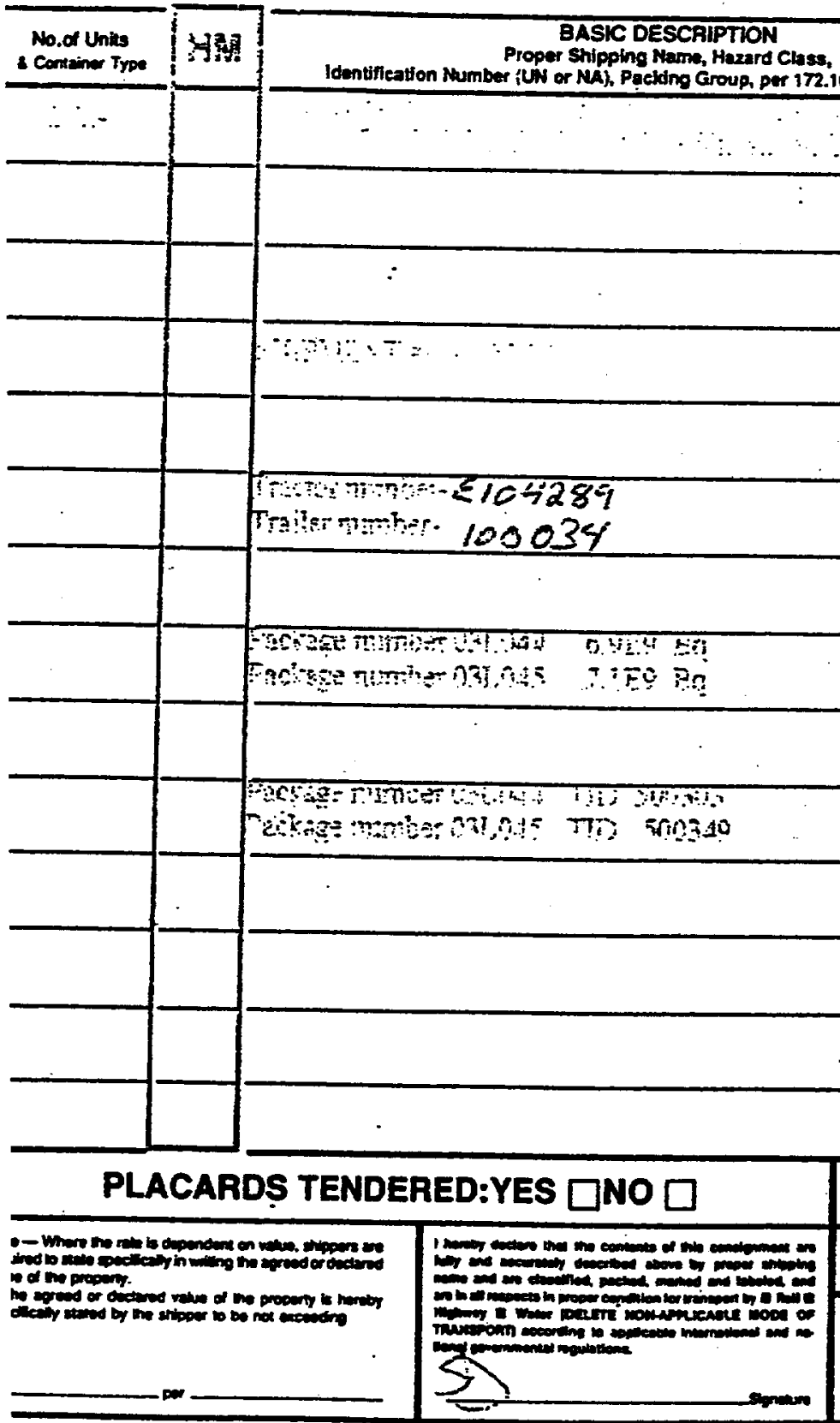

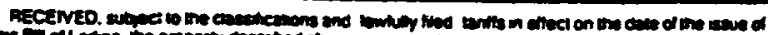

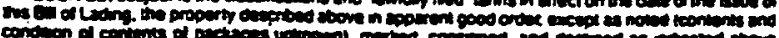

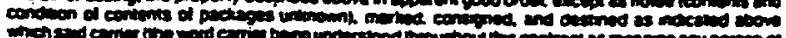

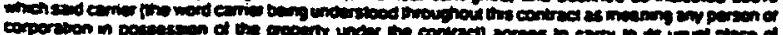

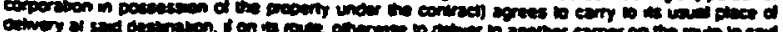

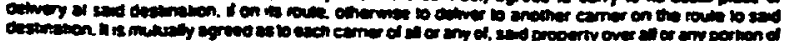

PER Bectel stcueds for US DOE

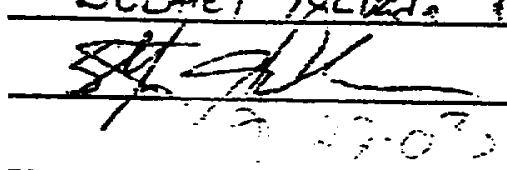

Ant: 5

TOTAL OUANTTY Oxions, ne-1

name Pat fehe

DATE BECHTE NEVADA

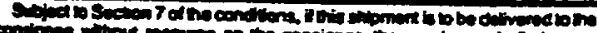

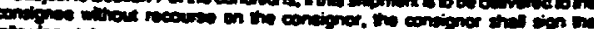

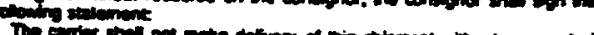

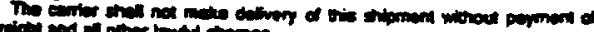

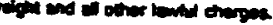

$$
\text { Rim }
$$

FREGHT CHARGES

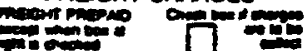

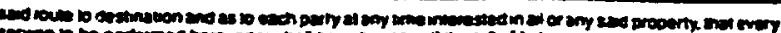

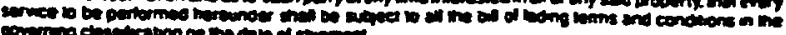

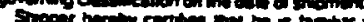

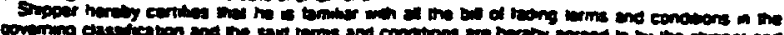

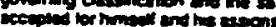
CARRIER \# PER $\quad \mid$ DATE $\because \because \because \quad \because r^{\circ}$ 


\section{Package Storage and Disposal Request}

Shipment Number. DPL03020

Date: $15-S e p-2003$

Prepared By:

Manifest Number:

\begin{tabular}{|c|c|c|c|c|c|}
\hline $\begin{array}{l}\text { Package No: } \\
\text { Container Code: } \\
\text { External Volume }\left(\mathrm{m}^{\wedge} 3\right) \\
\text { Waste Volume }\left(\mathrm{m}^{\wedge} 3\right) \text { : } \\
\text { Comment: }\end{array}$ & $\begin{array}{l}03 L 044 \\
230 \\
6.850 E+00 \\
6.170 E+00\end{array}$ & $\begin{array}{l}\text { Contact (mSv/h): } \\
1 \text { Meter (mSv/h): } \\
\text { Gross Weight (kg): } \\
\text { Net Weight (kg): }\end{array}$ & $\begin{array}{l}0.0005 \\
0.0005 \\
6.514 E+03 \\
6.492 E+03\end{array}$ & $\begin{array}{l}\text { Completed Date: } \\
\text { Operation Type: } \\
\text { Total Activity (bq): } \\
\text { Activity Date: }\end{array}$ & $\begin{array}{l}03-\text { Sep-2003 } \\
\text { B } \\
6.921 E+09= \\
10-\text { Sep-2003 }\end{array}$ \\
\hline
\end{tabular}

\begin{tabular}{|c|c|c|c|c|c|c|c|c|}
\hline $\begin{array}{c}\begin{array}{c}\text { Waste Stream } \\
\text { Profile }\end{array} \\
\text { LRY5LLFY00018 }\end{array}$ & $\begin{array}{l}\text { Form } \\
\text { Code }\end{array}$ & $\begin{array}{c}\text { Form } \\
\text { Description }\end{array}$ & $\begin{array}{c}\text { Treatment } \\
\text { Code }\end{array}$ & $\begin{array}{l}\text { Treatment } \\
\text { Description }\end{array}$ & $\begin{array}{l}\text { Rev. } \\
\text { No. }\end{array}$ & $\begin{array}{c}\begin{array}{c}\text { Revision } \\
\text { Date }\end{array} \\
\end{array}$ & Nuclide & $\begin{array}{l}\mathrm{Qty} \\
(\mathrm{Bq}) \\
\end{array}$ \\
\hline LRYSLLFYOOO18 & 022 & & 100 & & 103 & $01 \sqrt{u}-2003$ & U-231 & $9.100 E+08$ \\
\hline LRYSLFY00018 & 022 & & 100 & & 03 & 01-Jul-2003 & U-235 & 1.100E+07 \\
\hline & & & 100 & & 03 & 01Jut2003 & $0-233$ & $6.000 E+09$ \\
\hline
\end{tabular}

\begin{tabular}{|c|c|c|c|c|c|}
\hline $\begin{array}{l}\text { Package No: } \\
\text { Container Code: } \\
\text { External Volume }\left(\mathrm{m}^{\wedge} 3\right) \\
\text { Waste Volume }\left(\mathrm{m}^{\wedge} 3\right) \text { : } \\
\text { Comment. }\end{array}$ & $\begin{array}{l}03 L 045- \\
\dot{\dot{2}} 30 \\
6.850 E+00 \\
6.170 E+00\end{array}$ & $\begin{array}{l}\text { Contact (mSv/h): } \\
1 \text { Meter (mSv/h): } \\
\text { Gross Weight }(\mathrm{kg}) \text { : } \\
\text { Net Weight (kg): }\end{array}$ & $\begin{array}{l}0.0005 \\
0.0005 \\
6.651 E+03 \\
6.628 E+03\end{array}$ & $\begin{array}{l}\text { Completed Date: } \\
\text { Operation Type: } \\
\text { Total Activity (bq): } \\
\text { Activity Date: }\end{array}$ & $\begin{array}{l}\text { 03-Sep-2003 } \\
\text { B } \\
7.041 E+09 / \\
10-5 e p-2003\end{array}$ \\
\hline
\end{tabular}

\begin{tabular}{|c|c|c|c|c|c|c|c|c|}
\hline $\begin{array}{c}\text { Waste Stream } \\
\text { /Proffle }\end{array}$ & $\begin{array}{l}\text { Form } \\
\text { Code }\end{array}$ & $\begin{array}{c}\text { Form } \\
\text { Description }\end{array}$ & \begin{tabular}{|c|}
$\begin{array}{c}\text { Treatment } \\
\text { Code }\end{array}$ \\
\end{tabular} & $\begin{array}{l}\text { Treatment } \\
\text { Description }\end{array}$ & $\begin{array}{l}\text { Rev. } \\
\text { No. }\end{array}$ & $\begin{array}{c}\begin{array}{c}\text { Revision } \\
\text { Date }\end{array} \\
\end{array}$ & Nuclide & $\begin{array}{l}\text { Qty } \\
(B q)\end{array}$ \\
\hline LRYYULYOOON8 & 022 & & 100 & & 03 & 01 Just2003 & 0 & $2300 E+00$ \\
\hline LRYSULYYO0018 & 022 & & 100 & & $\mathbf{1 0 3}$ & $01 \sqrt{u-2003}$ & U-235 & 1.100E+07 \\
\hline LRY5LLYY00018 & 022 & & 100 & & 03 & $01 \sqrt{21-2003}$ & U-238 & $6.100 E+19$ \\
\hline
\end{tabular}

Reviewed By: tefef 


$$
0.2 C 3 \leq 2<
$$

\section{Low-Level Waste Certification}

I certify that containers: $3 L C 44$

e3i.045

do not contain hazardous waste as defined in Title 40 CFR 261 or state of Nevada hazardous waste regulations:

1. According to the results of test performed in accordance with the requirements as specified in Subpart C of Title 261; and/or

2. According to the supporting documentation provided to me about the materials and processes that produced this waste.

To the best of my knowledge, I believe the information I have submitted is true, accurate, and complete.

Downis Sarck/allal

Generator Waste Certification Official (Print Name/Sign)
$9 / 22 / 63$

Date 
Certificate of Disposal

This is to certify that the, Waste Stream No., LRY5-LLFY00018 package numbers 03 L044 and 03L045 were shipped and received at the Nevada Test Site Radioactive Waste Management Site in Area 3 for disposal as stated below.

Stefan Duke

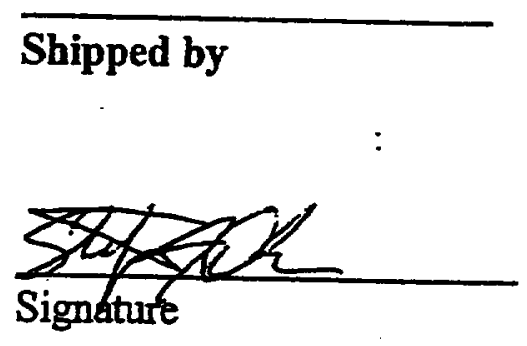

Michele Hampicil

Qliculledfeuh
Bechtel Nevada Waste Generator Services

Organization

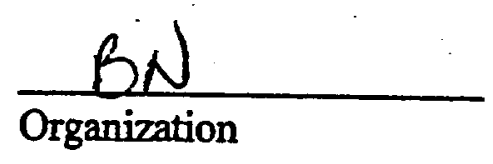

Date
Date

Scientist .

Title

9.22 .03

Title

RUMS

$9 / 22 / 02$ 


\section{HAZTRAK ENTRY CONFIRMATION}

Off-Site Shipment (From TTR at NEVADA to NTS at NEVADA)

Tracking No: DPL03021

CarTiEr: GOVERNMENT TRUCK

Depart 22-SEP-2003 10:00

Threshold: 22-SEP.2003 10:15
ATtival: 22-SEP-2003 15:30

Threstiold: 22-SEP-2003 15:C0
FTOM: ADAM DAEGORN

BECHTEL NEVADA

TONAPAH

CALATO ER SITE

TONAPAH, NY 89049

ANEB: CAUA10

Bidg: ER STTE

Phone: 702-295-4778
TO: SHANNON PARSONS-DEFRY

BECHTEL NEVADA

BASE CAMP

MERCURY, NV 89023

Area: 03

Bidg: 3 C36 (AHAT)

Phone: 702-295-7211

Pager.

Entered By: DUKESJ

Dato Modifited: 15-SEP-2003

Shippod Material(s)

Packagø(s) Unit(s) UNNA Guide
No.

REPORTABLE QUANTITY, WASTE

2 SUPER 16888.00

SACK(S) KILOGRAM(S)

2912162

RADIOACTIVE MATERLAL, LOW SPECIFIC ACTMTYY (LSA-1) (GROSS)

7. UN2912, RADIONUCLDES:U(DEPLETED) PHYSICAL FORM:SOLID CHEMICAL

FORMLOXIDE PACKAGE ACTIVTY:03LO46 9.0E9BQ, 03L047 9.0E9BQ

CATEGORY:LSA- EXCLUSME USE SHIPMENT

\section{4-Hr Emergency Response Number 702-295-0311}


smpper No.

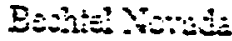

Name of exriel
Carnier No.

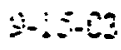

Date

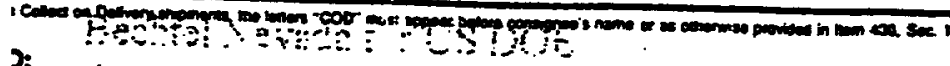

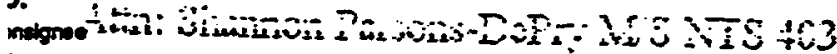

FO Bix:

at

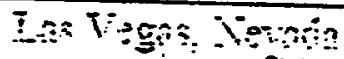

y

Zip Code
89193

b

No.of Unite

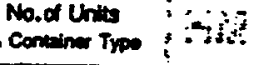

BASTC DESCRIPTION

Identhication Number (UN or Whipling Name, Hazard Clase,

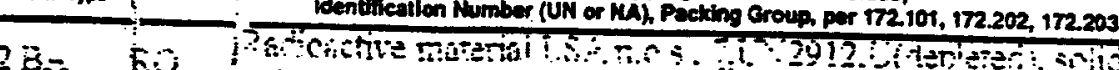

a 1 a

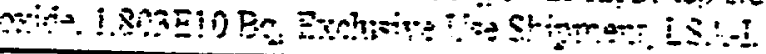

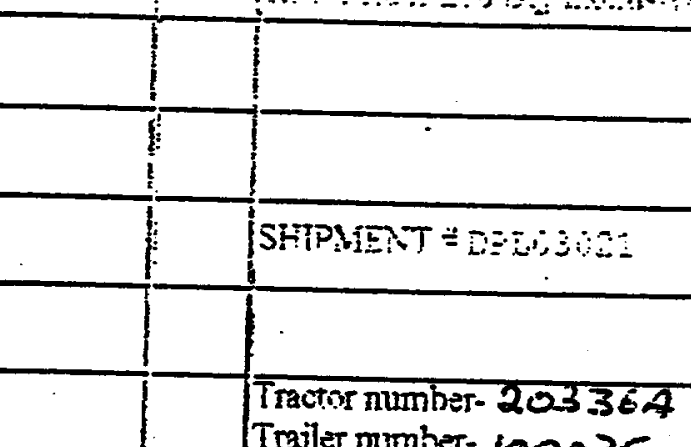

Trailer mimher-100035.

Paclage number 0.1.046 ONEO BG

Package number 03LC4 7 O.0E9 Ba

Pankage minber 03L.040 TID .000325

Package number 03L.047 TID 500324

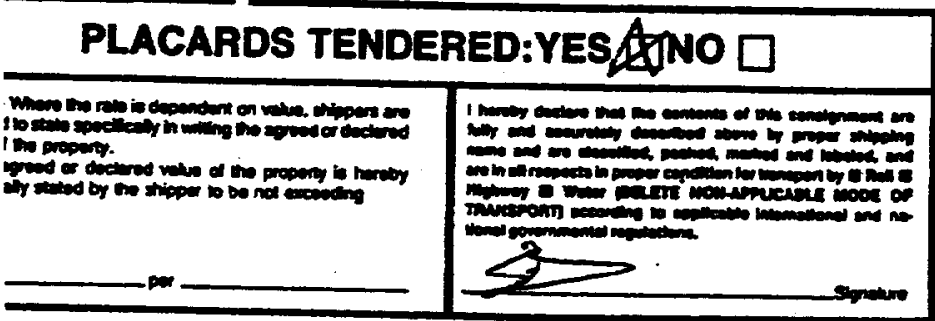

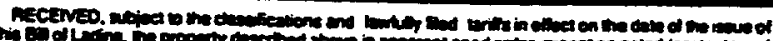

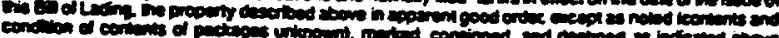

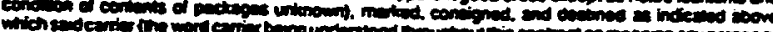

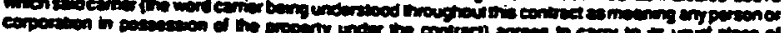

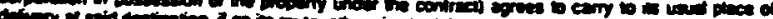

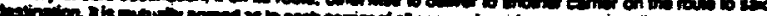

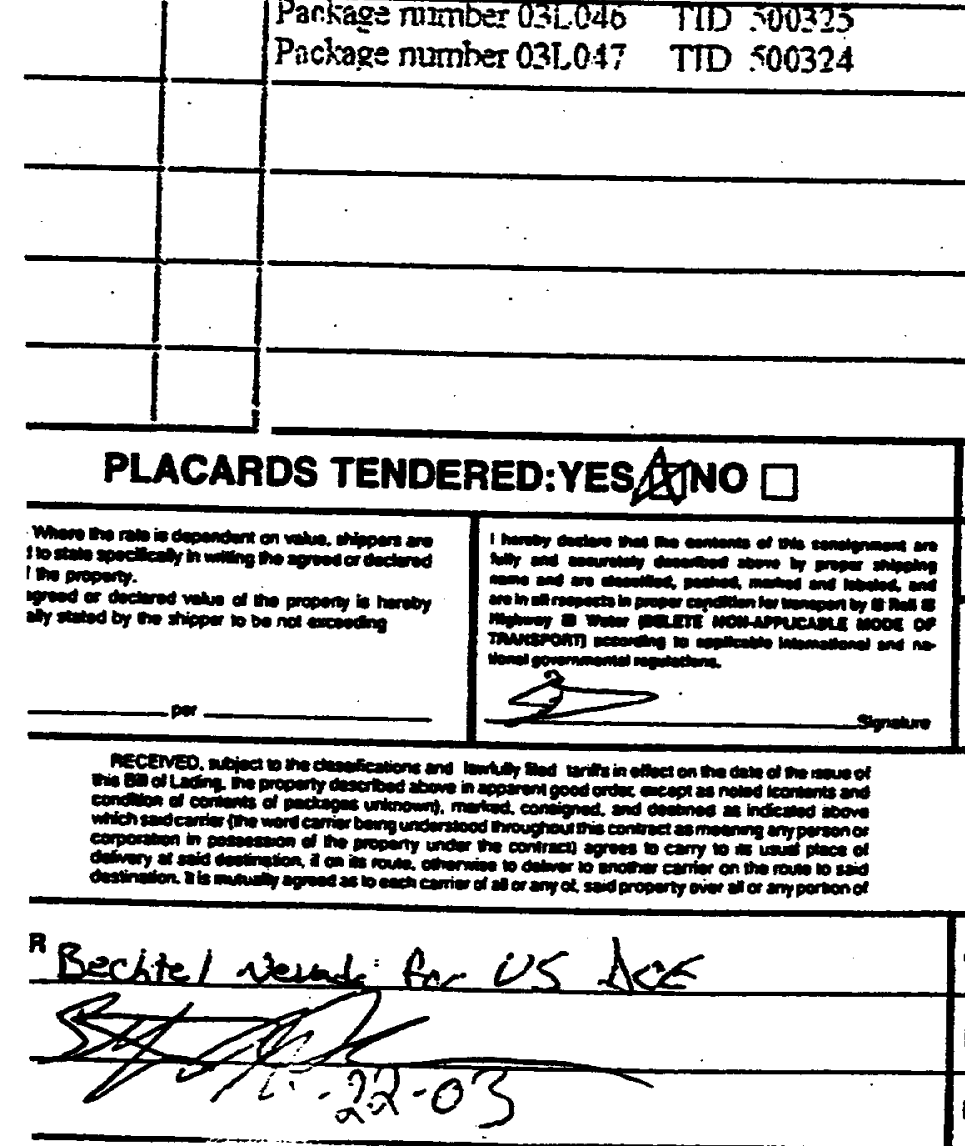

(SCAC)

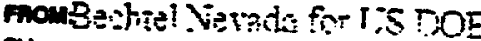

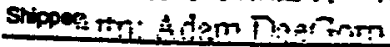

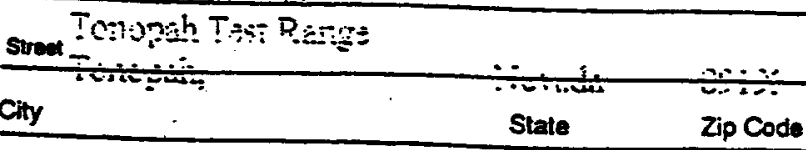

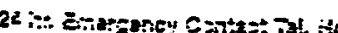

se.

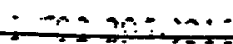

main to:

Aocoses:

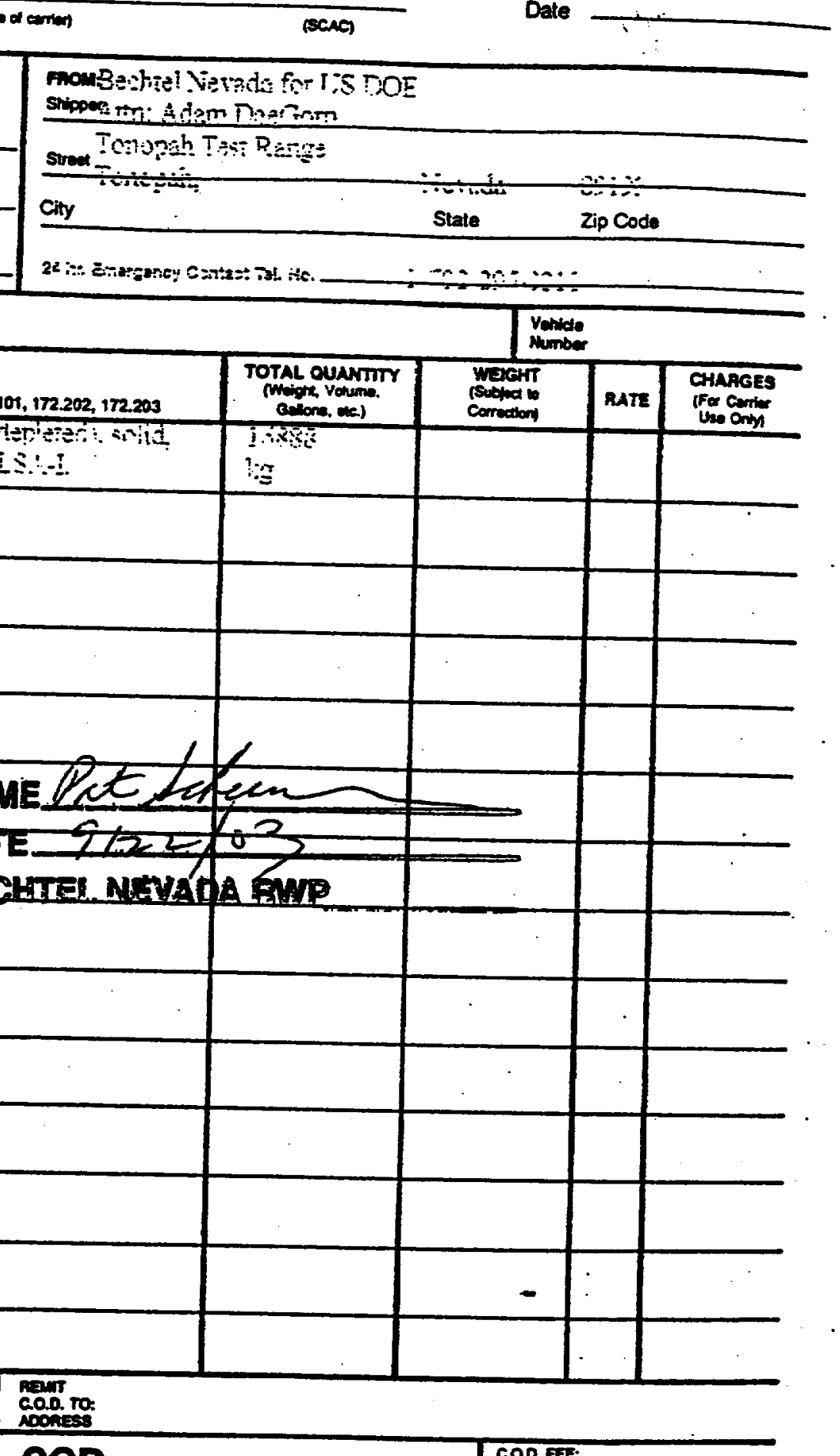

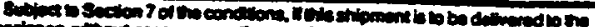

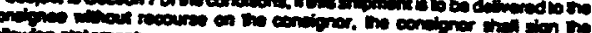

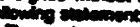

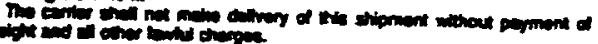

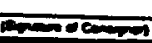

COD. FE:
CPSNO
CONECT

Tora GUARES: 5

FAEGHT CHARGES

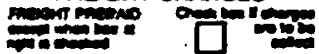

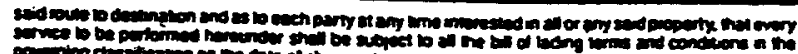
somenter

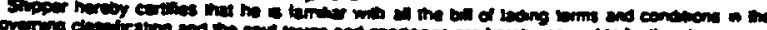

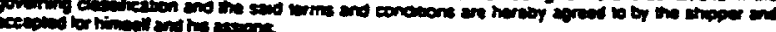

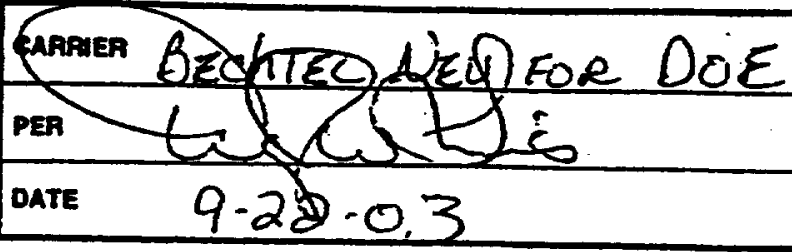

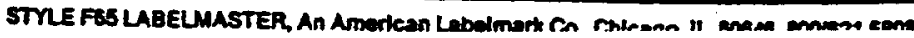




\section{Package Storage and Disposal Request}

Shipment Number: DPL03021

Date: 15-Sep-2003

Prepared By:

Manifest Number.

\begin{tabular}{|c|c|c|c|c|c|}
\hline Package No: & 03L046 & Contact (mSv/h): & 0.0005 & Completed Date: & $04-S e p-2003$ \\
\hline Container Code: & 230 & 1 Meter $(\mathrm{mSv} / \mathrm{h})$ : & 0.0005 & Operation Type: & B. \\
\hline External Volume $\left(m^{\wedge} 3\right)$ & $6.850 E+00$ & Gross Weight $(\mathrm{kg})$ : & $8.467 E+03$ & Total Activity (bq): & $9.014 E+0$ \\
\hline
\end{tabular}

\begin{tabular}{|c|c|c|c|c|c|c|c|c|}
\hline $\begin{array}{c}\begin{array}{c}\text { Waste Stream } \\
\text { Protile }\end{array} \\
\text { LRY5LLYFOOO18 }\end{array}$ & $\begin{array}{l}\text { Form } \\
\text { Code }\end{array}$ & $\begin{array}{c}\text { Form } \\
\text { Description }\end{array}$ & $\begin{array}{c}\text { Treatmenli } \\
\text { Code }\end{array}$ & $\begin{array}{l}\text { Treatment } \\
\text { Description }\end{array}$ & $\begin{array}{l}\text { Rev. } \\
\text { No. }\end{array}$ & $\begin{array}{c}\text { Revision } \\
\text { Date }\end{array}$ & Nuclide & $\begin{array}{l}\text { Oty } \\
\text { (Bq) }\end{array}$ \\
\hline LRY5LLFYO0O18 & 022 & & 100 & & 03 & 01 Jut2003 & 16.234 & $1,200 E+09$ \\
\hline LRY5LLFY00018 & 022 & & 100 & & 03 & $04 \sqrt{u b-2003}$ & 0.235 & $1.400 E+07$ \\
\hline LRYSLLFY00018 & 022 & & 100 & & 03 & $01-\sqrt{u}-2003$ & U-238. & $7.800 E+09$ \\
\hline
\end{tabular}

\begin{tabular}{|c|c|c|c|c|c|}
\hline $\begin{array}{l}\text { Package No: } \\
\text { Container Code: } \\
\text { External Volume }\left(m^{\wedge} 3\right) \\
\text { Waste Volume }\left(m^{\wedge} 3\right): \\
\text { Comment: }\end{array}$ & $\begin{array}{l}03 L 047 \\
230 \\
6.850 E+00 \\
6.170 E+00\end{array}$ & $\begin{array}{l}\text { Contact }(\mathrm{mSv} / \mathrm{h}) \text { : } \\
1 \text { Meter }(\mathrm{mSv} / \mathrm{h}): \\
\text { Gross Weight }(\mathrm{kg}) \text { : } \\
\text { Net Weight }(\mathrm{kg}) \text { : }\end{array}$ & $\begin{array}{l}0.0005 \\
0.0005 \\
8.421 E+03 \\
8.399 E+032\end{array}$ & $\begin{array}{l}\text { Completed Date: } \\
\text { Operation Type: } \\
\text { Total Activity (bq): } \\
\text { Activity Date: }\end{array}$ & $\begin{array}{l}\text { O4-Sep-2003 } \\
\text { B } \\
9.014 E+09 \text {, } \\
\text { 09-Sep-2003 }\end{array}$ \\
\hline
\end{tabular}

\begin{tabular}{|c|c|c|c|c|c|c|c|c|}
\hline $\begin{array}{c}\begin{array}{c}\text { Waste Stream } \\
\text { Profile }\end{array} \\
\end{array}$ & \begin{tabular}{|l|} 
Form \\
Code
\end{tabular} & $\begin{array}{c}\text { Form } \\
\text { Description }\end{array}$ & $\begin{array}{c}\text { Treatment } \\
\text { Code }\end{array}$ & $\begin{array}{l}\text { Treatment } \\
\text { Description }\end{array}$ & $\begin{array}{l}\text { Rev. } \\
\text { No. } \\
\end{array}$ & $\begin{array}{c}\begin{array}{c}\text { Revision } \\
\text { Date }\end{array} \\
\end{array}$ & Nucllde & $\begin{array}{l}\text { Qty } \\
(B q)\end{array}$ \\
\hline LRY5LIFYO0018 & 022 & & 100 & & 03 & $01-J u t-2003$ & 0.234 & $1.200 E+09$ \\
\hline LRYSLFYO0018 & 022 & & 100 & & 03 & $01-\sqrt{e}+2003$ & U-235 & 1.400E+07 \\
\hline LRYSLFYOO0018 & 022 & & 100 & & 03 & $01 \sqrt{u}-2003$ & U.233 & $7.800 E+09$ \\
\hline
\end{tabular}




$$
0 ;<<3=21
$$

\section{Low-Level Waste Certification}

I certify that containers: $\quad 3<+46$.

$$
\text { c36.5.4\% }
$$

do not contain hazardous waste as defined in Title 40 CFR 261 or state of Nevada hazardous waste regulations:

1. According to the results of test performed in accordance with the requirements as specified in Subpart C of Title 261; and/or

2. According to the supporting documentation provided to me about the materials and processes that produced this waste. To the best of my knowledge, I believe the information I have submitted is true, accurate,
and complete.

Denoir suick / elengl Generator Waste Certification Official (Print Name/Sign)
$2 / 12 / 03$ Date 


\section{Certificate of Disposal}

This is to certify that the, Waste Stream No., LRY5-LLFY00018 package numbers 03L046 and 03L047 were shipped and received at the Nevada Test Site Radioactive Waste Management Site in Area 3 for disposal as stated below.

Stefan Duke

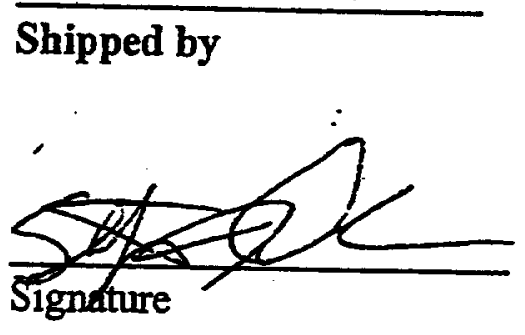

ED TARAHASH

Received by

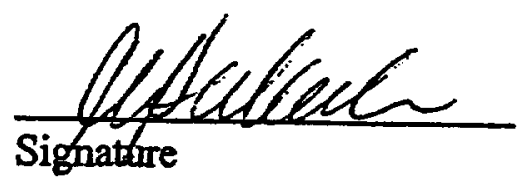

Bechtel Nevada Waste Generator Services

Scientist

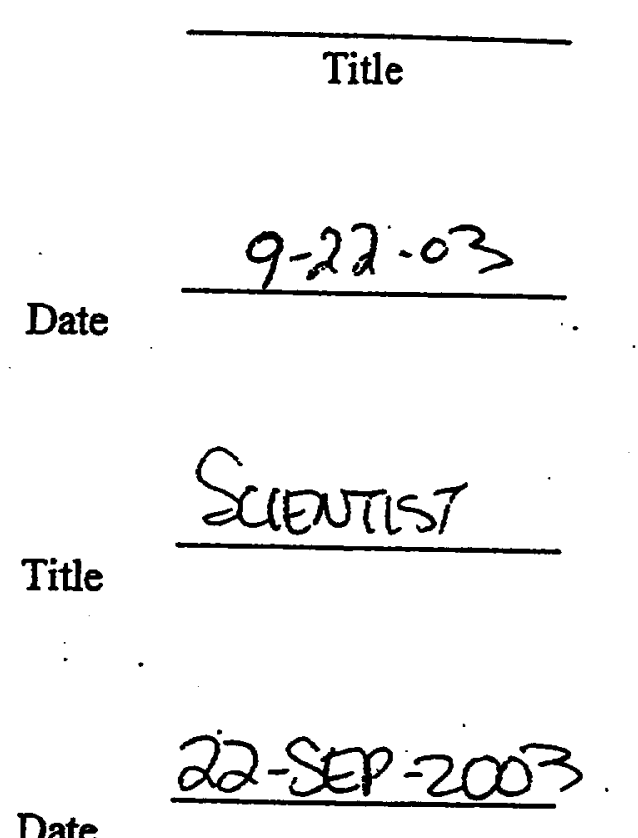

Ba $(0) 0$

Organization

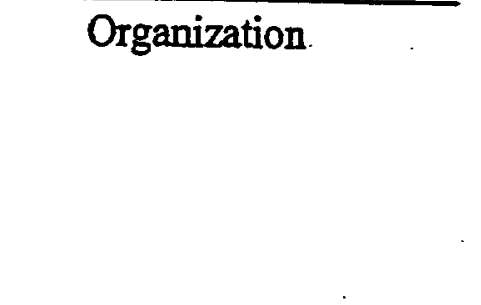

Date 


\section{HAZTRAK ENTRY CONFIRMATION}

\section{Off-Site Shipment (From TTR at NEVADA to NTS at NEVADA)}

Tracking No: DPL03022

Carrier: GOVERNMENT TRUCK

Artival: 23-SEP-2003 15:30

Threshold: 23-SEP-2003 15:00

TO: . SHANNON PARSONS-DEPRY

BECHTEL NEVADA

BASE CAMP

MERCURY, NV 89023

Area: 03

Bldg: 3 C36 (AHAT)

Phone: 702-295-7211

Pager:

Entered By: DUKESJ

Date Modified: 15-SEP-2003

Shipped Material(s)

Package(s) Unit(s)

Guide No.

REPORTABLE QUANTITY, WASTE

2 SUPER

17047.00

KILOGRAM(S)

2912

RADIOACTME MATERIAL, LOW SPECIFIC ACTIVTY (LSA-1)

(GROSS)

7. UN2912. RADIONUCLIDES:U(DEPLETED) PHYSICAL FORM:SOLID CHEMICAL FORM:OXIDE PACKAGE ACTIVITY:03L048 9.0E9BQ, 03LO49 9.2E9BQ CATEGORY:LSA-I EXCLUSIVE USE SHIPMENT

\section{4-Hr Emergency Response Number}

702-295-0311 
Srupper No.

Carrier No.

Page __ of

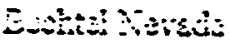

$2=0$

Avane of contien

Date

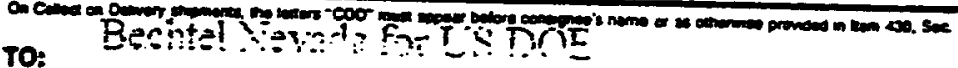

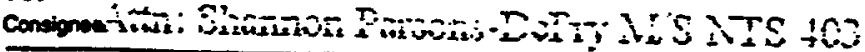

sue FO 3 :

\begin{tabular}{|c|c|c|}
\hline & 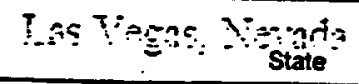 & Zip Code $29 ! 9$ \\
\hline
\end{tabular}

ove

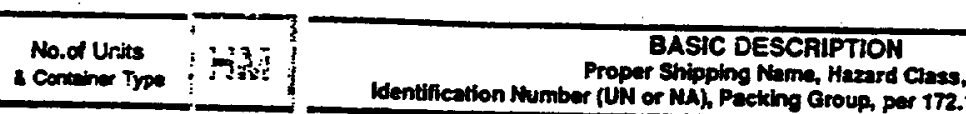

İ- $\quad$ L

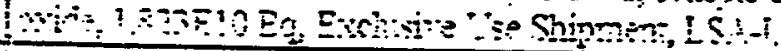

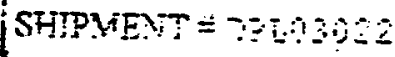

Tracror Mimber- 203864

Trajlet nunber- 100075 .

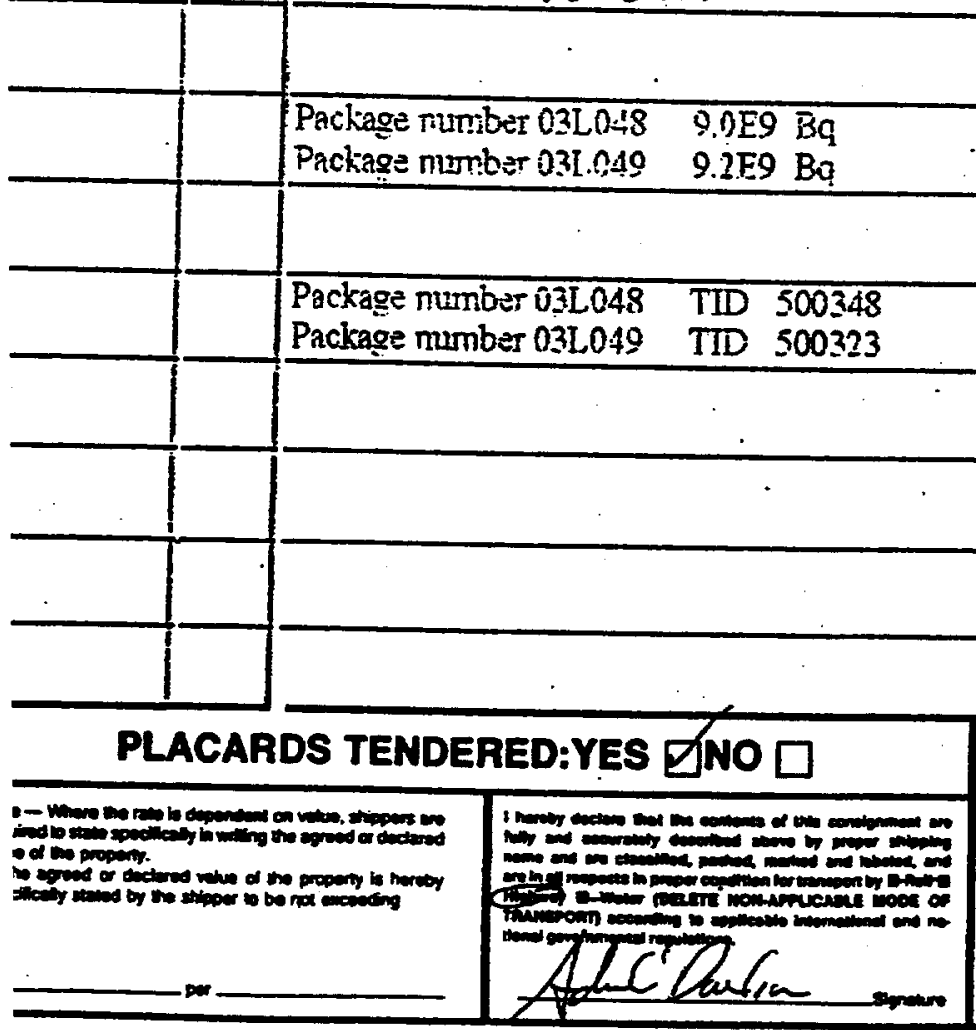

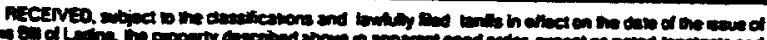

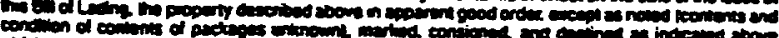

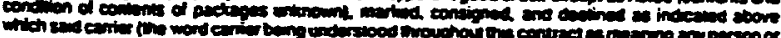

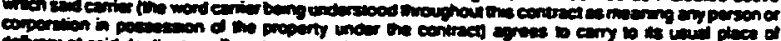

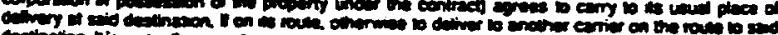

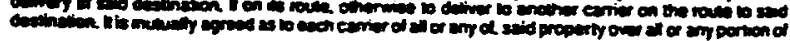

ren BechtilNeand for USDOE

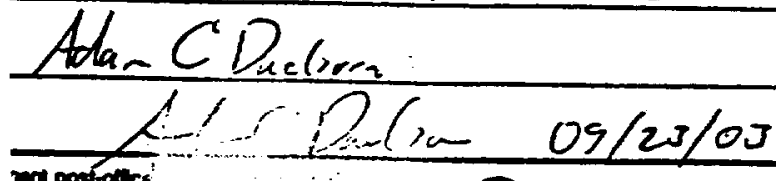

mit postotice

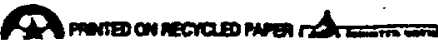

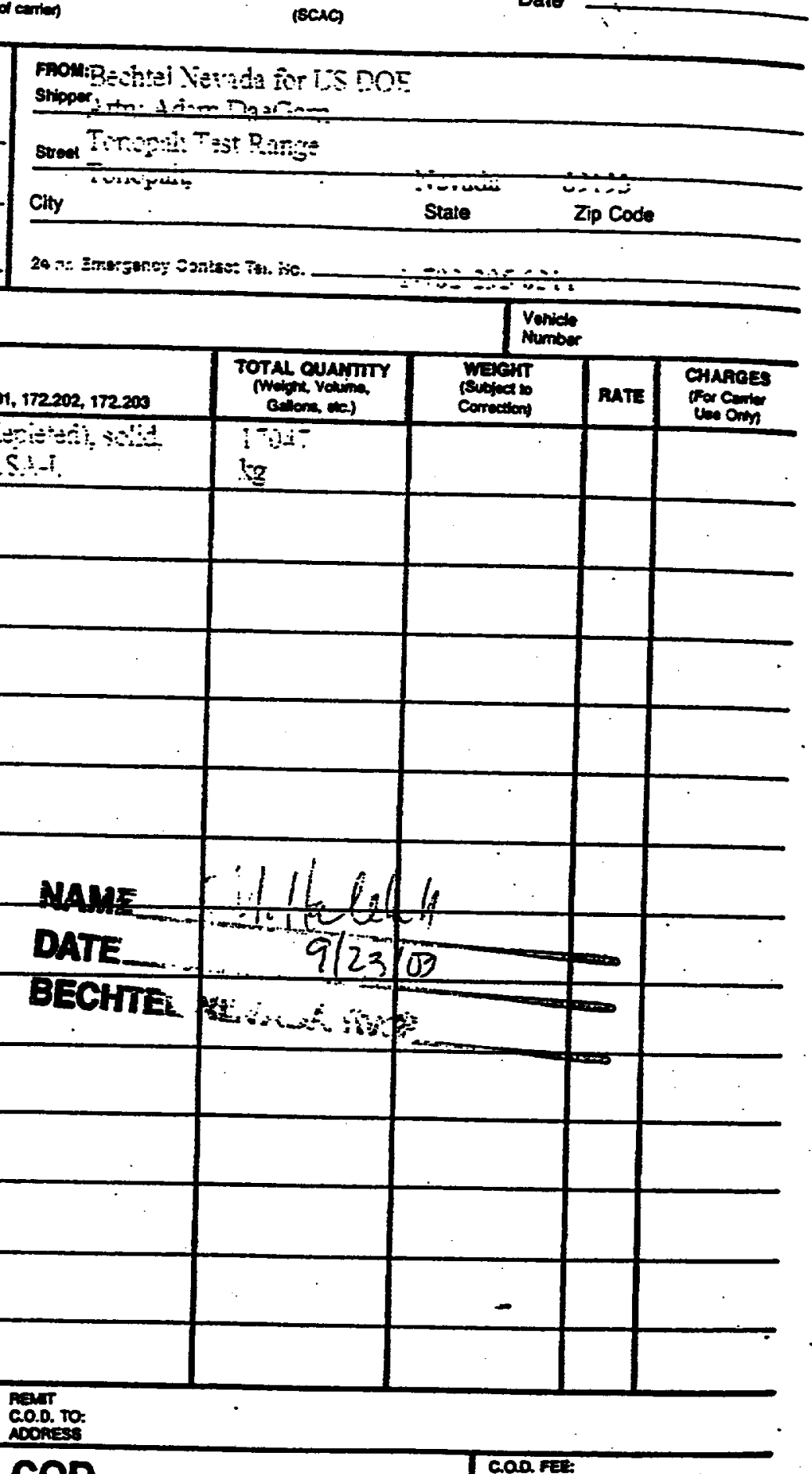

iscia

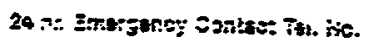

\section{RaT}

Co.D. To:

aconses

Ant: 5

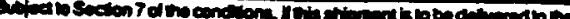

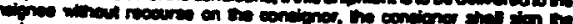

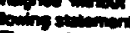

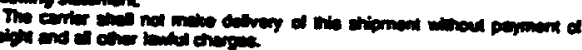

$$
\text { Dind }
$$

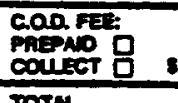

\section{Total}

Cunfess:

FPECHT CWHES

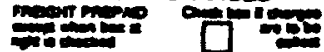

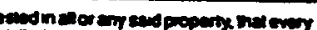

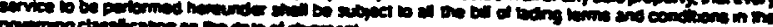

gron

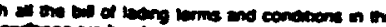

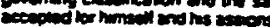

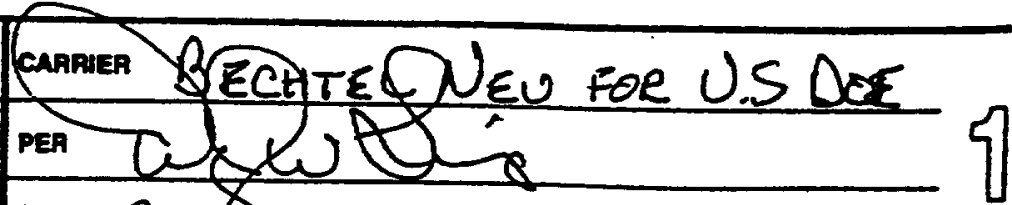

date $9.2^{8}-03$

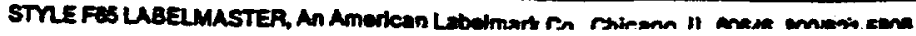




\section{Package Storage and Disposal Request}

Shipment Number. DPL03022

Date: $15-\operatorname{Sep}-2003$

Prepared By:

Manifest Number:

\begin{tabular}{|c|c|c|c|c|c|}
\hline Package No: & $03 L 048$ & Contact (msv/h): & 0.0005 & Completed Date: & $04-\operatorname{Sep}-2003$ \\
\hline Container Code: & 230 & 1 Meter (mSv/h): & 0.0005 & Operation Type: & $\mathbf{B}$ \\
\hline $\begin{array}{l}\text { External Volume }\left(m^{\wedge} 3\right) \\
\text { Waste Volume }\left(m^{\wedge} 3\right) \text { : } \\
\text { Comment: }\end{array}$ & $\begin{array}{l}6.850 E+00 / \\
6.170 E+00\end{array}$ & $\begin{array}{l}\text { Gross Weight }(\mathrm{kg}): \\
\text { Net Weight }(\mathrm{kg}):\end{array}$ & $\begin{array}{l}8.421 E+03 \\
8.399 E+03\end{array}$ & $\begin{array}{l}\text { Total Activity (bq): } \\
\text { Activity Date: }\end{array}$ & $\begin{array}{l}9.014 E+09 \\
09-S e p-2003\end{array}$ \\
\hline
\end{tabular}

\begin{tabular}{|c|c|c|c|c|c|c|c|c|}
\hline $\begin{array}{c}\begin{array}{c}\text { Waste Stream } \\
\text { Profile }\end{array} \\
\end{array}$ & $\begin{array}{l}\text { Form } \\
\text { Code }\end{array}$ & $\begin{array}{c}\text { Form } \\
\text { Description }\end{array}$ & $\begin{array}{c}\text { Treatment! } \\
\text { Code }\end{array}$ & $\begin{array}{l}\text { Treatment } \\
\text { Description }\end{array}$ & $\begin{array}{l}\text { Rev. } \\
\text { No. }\end{array}$ & $\begin{array}{c}\text { Revision } \\
\text { Date }\end{array}$ & Nuclide & $\begin{array}{l}\text { Qty } \\
\text { (Bq) }\end{array}$ \\
\hline LRYSLLFY00018 & 022 & & 100 & & 03 & $01-J u 1-2003$ & U-231 & $1.200 E+\infty$ \\
\hline LRYSLLYY0Q918 & 022 & & 100 & & 03 & 01 Juk2003 & U.235 & 1.400E+07 \\
\hline LRYSLIFY00018 & 022 & & 100 & & 03 & $01-J u f-2003$ & 0.238 & $7.800 E+\infty$ \\
\hline
\end{tabular}

\begin{tabular}{|c|c|c|c|c|c|}
\hline $\begin{array}{l}\text { Package No: } \\
\text { Container Code: } \\
\text { Extemal Volume (m^3) } \\
\text { Waste Volume (m^3): } \\
\text { Comment. }\end{array}$ & $\begin{array}{l}03 L 049 \\
230 \\
6.850 E+00 \\
6.170 E+00\end{array}$ & $\begin{array}{l}\text { Contact (mSv/h): } \\
1 \text { Meter (mSvm): } \\
\text { Gross Weight (kg): } \\
\text { Net Weight (kg): }\end{array}$ & $\begin{array}{l}0.0005 \\
0.0005 \\
8.626 E+03 \\
8.603 E+03 /\end{array}$ & $\begin{array}{l}\text { Completed Date: } \\
\text { Operation Type: } \\
\text { Total Acthity (bq): } \\
\text { Activity Date: }\end{array}$ & $\begin{array}{l}\text { 04-Sep-2003 } \\
\text { B } \\
9.215 E+09 \\
\text { 09-Sep-2003 }\end{array}$ \\
\hline
\end{tabular}

\begin{tabular}{|c|c|c|c|c|c|c|c|c|}
\hline $\begin{array}{c}\text { Waste Stream } \\
\text { Profile } \\
\end{array}$ & \begin{tabular}{|l|} 
Form \\
Code
\end{tabular} & $\begin{array}{c}\text { Form } \\
\text { Description }\end{array}$ & \begin{tabular}{|c|}
$\begin{array}{c}\text { Treatment } \\
\text { Code }\end{array}$ \\
\end{tabular} & $\begin{array}{c}\text { Treatment } \\
\text { Description }\end{array}$ & $\begin{array}{l}\text { Rev. } \\
\text { No. }\end{array}$ & \begin{tabular}{c|}
$\begin{array}{c}\text { Revision } \\
\text { Date }\end{array}$ \\
\end{tabular} & Nucilde & $\begin{array}{l}\text { Qty } \\
(B q)\end{array}$ \\
\hline LRYSLLFYOOOT8 & 022 & & 100 & & 03 & $01 \sqrt{u}-2003$ & $\sqrt{1-234}$ & $1200 E+05$ \\
\hline LRYSLLFYO0018 & 022 & & 100 & & 03 & 04 لvul2003 & 0.235 & $1.500 E+07$ \\
\hline LRYSLIFY00018 & 022 & & 100 & & 03 & $01 \sqrt{u} u-2003$ & 0.238 & $8.000 E+09$ \\
\hline
\end{tabular}

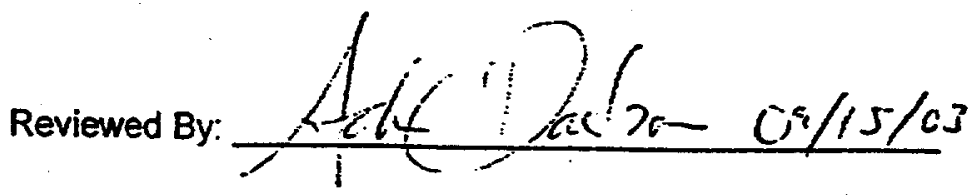


Certificate of Disposal

This is to certify that the, Waste Stream No., LRY5-LLFY00018 package numbers 03L048 and 03L049 were shipped and received at the Nevada Test Site Radioactive Waste Management Site in Area 3 for disposal as stated below.

Stefan Duke

Shipped by
Bechtel Nevada Waste Generator Services

Organization
Scientist

Title

Date

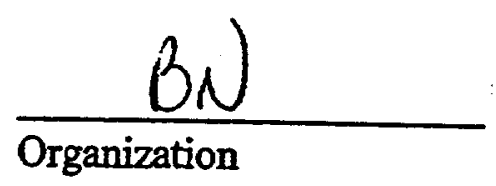

chléchestal

Signature
$9 / 23100$
Title

$R \omega$

Date 
Low-Level Waste Certification

$$
\begin{aligned}
& \text { Shipment } A \\
& \Delta P C 03022
\end{aligned}
$$

I cerify that containers: 031048

036049

do not contain hazardous waste as defined in Title 40 CFR 261 or state of Nevada hazardous waste regulations:

1. According to the results of test performed in accordance with the requirements as specified in Subpart C of Title 261; and/or

2. According to the supporting documentation provided to me about the materials and processes that produced this waste.

To the best of my knowledge, I believe the information I have submitted is true, accurate, and complete.

Dowors Swrek/alideh

Generator Waste Certification Official (Print Name/Sign)
$9 / 23 / 03$

Date 


\section{HAZTRAK ENTRY CONFIRMATION}

Off-Site Shipment (From TTR at NEVADA to NTS at NEVADA)

Tracking No: DPL03023

Carier: GOVERNMENT TRUCK

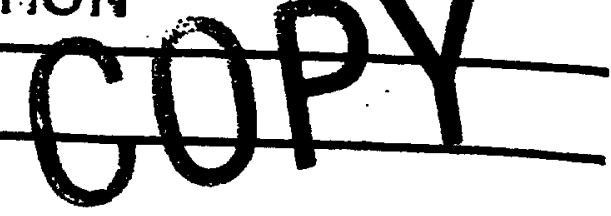

COL: ONFILE NV

Eesart: 23-SEP-2003 10:30

T:rsshcld: 23-EEP-2SC3 10:-

Arrival: 23-SEP-20C3 :5:30

Threshold: 23-5EP-2003 15:00

From: $A D A M$ DAEGCRN

BECHTEL NEVADA

TONAPAH

CAU410 ER SITE

TONAPAH, NV 89049

TO: SHANNON PARSONS-DEFRY

BECHTEL NEVADA

BASE CAMP

MERCURY, NV 89023

Area: CAL410 :

BIdg: ER SITE

Phone: 702-295-4779

Area: 03

Bldg: 3 C36 (AHAT)

Phone: 702-295-7211

Pager:

Entered By: DUKESJ

Date Modified: $\quad$ 15-SEP-2003

Shlpped Material(s)

Package(s) Unit(s) UNNA Guide

REPORTABLE QUANTTY, WASTE

RADIOACTME MATERIAL, LOW SPECIFIC ACTIVTTY (LSA-1)

1 SUPER

SACK(S)

7105.00 KILOGRAM 2912162

7. UN2912 RADIONUCLIDES:U(DEPLETED) PHYSICAL FORM:SOLID CHEMICAL

FORM:OXIDE PACKAGE ACTIVITY:03L050 7.612E9 BQ CATEGORY:LSA-1 EXCLUSME USE
SHIPMENT

\section{4-Hr Emergency Response Number \\ 702-295-0311}




$\frac{\therefore}{\text { [SCAC] }}$

Date $2+\frac{1}{2}=-33$

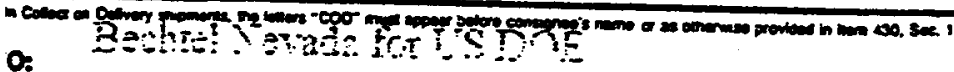

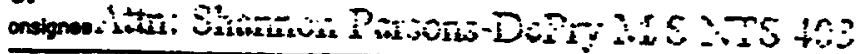

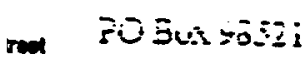

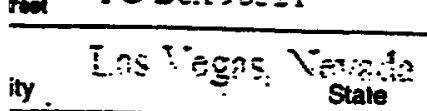
Zip code $\$ 919 ?$

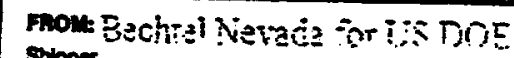

soper $i \rightarrow n$.

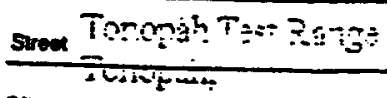

$\longrightarrow$

City $\quad$ State $\quad$ Zp Code

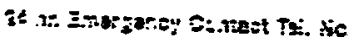

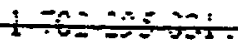

se

No.or units

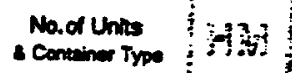

QASTC DESCRIPTION

Conamer Type :3.7.

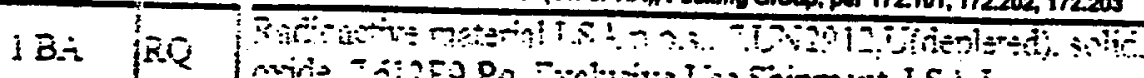

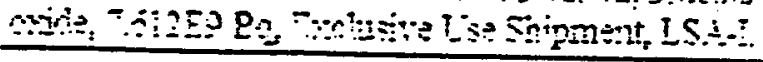

SHPVIFAT SEI03033

בוב

PLACARDS TENDERED:YES $\square$ NO $\square$

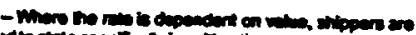

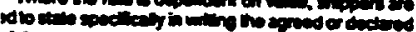
at the propowy.

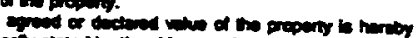

Package nimber 03LOSO 7.059 Bo

Package number 0.3L050 TID 501103

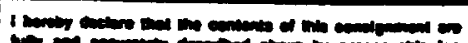

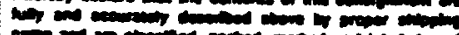

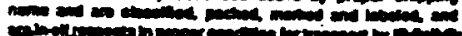
- 7 rom

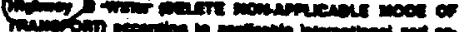

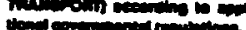
Atcilaco

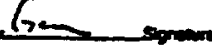


Certificate of Disposal

This is to certify that the, Waste Stream No.. LRY5-LLFY00018 package numbers 03L050 was shipped and received at the Nevada Test Site Radioactive Waste Management Site in Area 3 for
disposal as stated below.

Stefan Duke

Shipped by
Bechtel Nevada Waste Generator Services

Organization
Scientist

Title

$B N$

Organization
Date

$09 / 18 / 03$

Title

Rims

Date

$9 / 23 / 03$ 
Low-Level Waste Certification

$$
\begin{aligned}
& \text { Shipment } \\
& \text { OPLO3023 }
\end{aligned}
$$

I certify that containers: $03 \angle 050$

do not contain hazardous waste as defined in Title 40 CFR 261 or state of Nevada hazardous waste regulations:

1. According to the results of test performed in accordance with the requirements as specified in Subpart C of Title 261; and/or

2. According to the supporting documentation provided to me about the materials and processes that produced this waste. To the best of my knowledge, I believe the information I have submitted is true, accurate,
and complete.

Dewir Swickfalendal

Generator Waste Certification Official (Print Name/Sign)

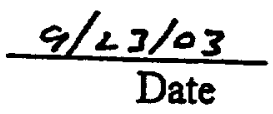


- aunaye storage and Disposal Request

Shipment Number. DPL03023

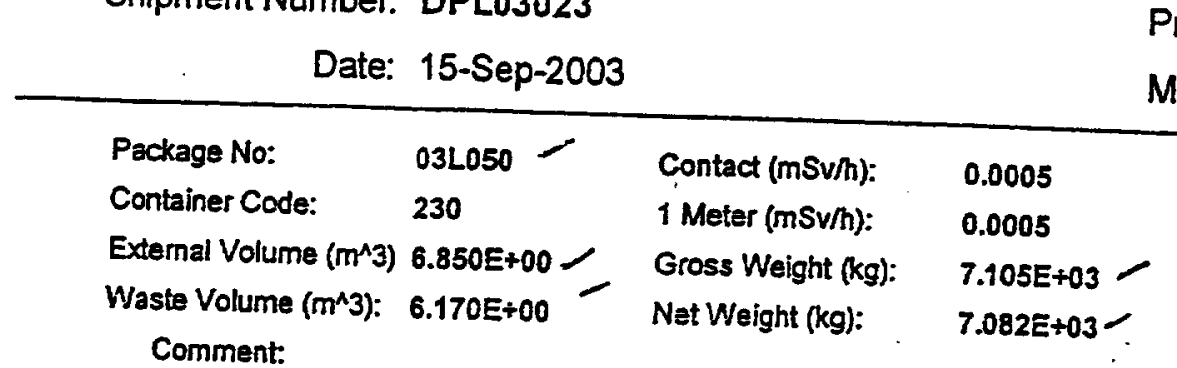

Prepared By:

Manifest Number!

Completed Dale:

Operation Type:

Total Activity (ba):

Activity Date:
08-Sep-2003

B

7.612E+09 م.

10-Sep-2003

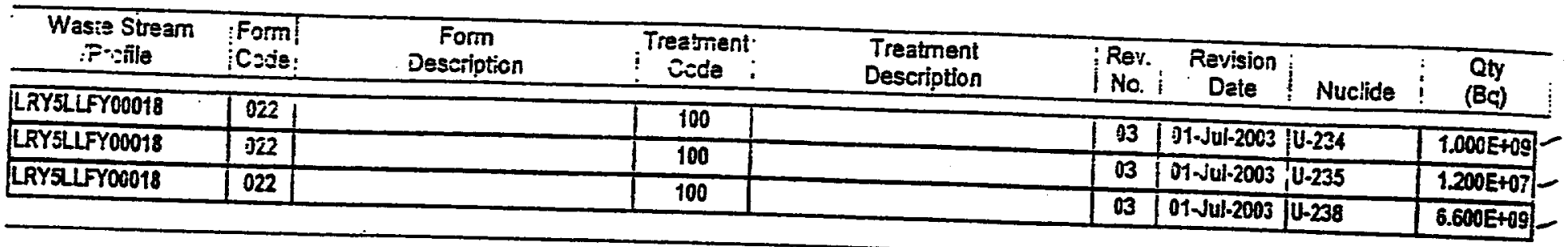

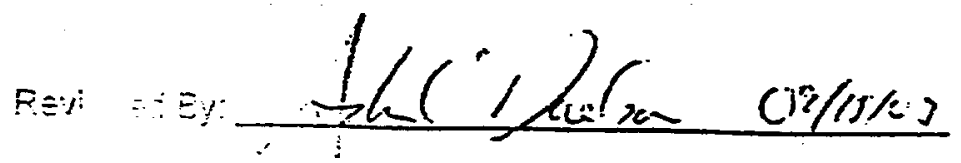

Page 1 of 1 


\section{Appendix F}

Nevada Division of Environmental Protection Comment Responses 
NEVADA ENVIRONMENTAL RESTORATION PROJECT

DOCUMENT REVIEW SHEET

\begin{tabular}{|c|c|c|c|c|c|}
\hline \multicolumn{4}{|c|}{$\begin{array}{l}\text { 1. Document Title/Number: Draft Corrective Action Decision Document/Closure Report for Corrective } \\
\text { Action Unit 410: Waste Disposal Trenches, Tonopah Test Range, Nevada }\end{array}$} & \multicolumn{2}{|c|}{ 2. Document Date: November 2003} \\
\hline \multicolumn{4}{|c|}{ 3. Revision Number: 0} & \multicolumn{2}{|c|}{ 4. Originator/Organization: Stoller-Navarro } \\
\hline \multicolumn{4}{|c|}{ 5. Responsible NNSA/NV ERP Project Mgr.: Janet Appenzeller-Wing } & \multicolumn{2}{|c|}{ 6. Date Comments Due: December 4, 2003} \\
\hline \multicolumn{6}{|c|}{ 7. Review Criteria: Full } \\
\hline \multicolumn{4}{|c|}{ 8. Reviewer/Organization/Phone No.: Clem Goewert/Don Elle, NDEP, 486-2874 } & \multicolumn{2}{|l|}{ 9. Reviewer's Signature: } \\
\hline \multirow[t]{2}{*}{$\begin{array}{l}\text { 10. Comment } \\
\text { Number/ } \\
\text { Location }\end{array}$} & 11. Type ${ }^{*}$ & 12. Comment & \multicolumn{2}{|c|}{ 13. Comment Response } & 14. Accept \\
\hline & & NDEP has no comments on this document. & & & \\
\hline
\end{tabular}

${ }^{a}$ Comment Types: $M=$ Mandatory, $S=$ Suggested.

Return Document Review Sheets to NNSA/NV Environmental Restoration Division, Attn: QAC, M/S 505. 
DEC.12.2UG3 12:DOPM DOE NVOO ERD

ALLEN BLAGGi, Administrotor

Administration

Water Pallution Control

Air Quality

(702) 486-2850
CAU 410 CADD/CR

Appendix $F$

Revision: 0

Date: $12 / 22 / 2003$

Page F-2 of F-2
No.582 P.2/2

R. MICHALL, TURNIPSEED, Dinector

Federal Faclities

Corrective Actions

Woste Management

Facsimile 486-2863

DEPARTMENT OF CONSERVATION AND NATURAL RESOURCES

\section{DIVISION OF ENVIRONMENTAL PROTECTION}

(Las Vegas Office)

1771 E. Flamingo Road, Suite 121-A

Las Vegas, Nevada 89119-0837

November 24, 2003

... Ms. RumoraC. Wyeoff

Director, Environmental Restoration Division

Nevada Nuclear Security Administration

Nevada Site Office

P. O. Box 98518

Las Vegas, NV $89193-8518$

RE: Review of Draft CADD/CR

Corrective Action Unit 410, Waste Disposal Trenches

Federal Facility Agreement and Consent Order

The Nevada Division of Environmental Protection, Bureau of Federal Facilities (NDEP) staff reviewed the draft Corrective Action Decision/ Closure Report (CADD/CR) for Corrective Action Unit (CAU) 410, Waste Disposal Trenches. NDEP's review of this document did not indicate any deficiencies.

Address any questions regarding this matter to either Clem Goewert at (702) 486-2865, or me at (702) $486-2874$

Sincerely,

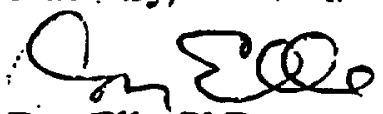

Don Elle, $\mathrm{PhD}$

Supervisor

Bureau of Federal Facilities

\section{TM/KKB/DRE/CG}

cc: Ken Hoar, Director, ES\&HD, NNSANSO

Patti Hall, EM, NNSA NSO

Wayne Griffin, BN/DTRA

Janet Appenzeller-Wing, ERD, NNSA/ NSO
Eric Shanholtz, Chief, DTRA

Frank Di Sanza, WMD, NNSA NSO

Tiffany Lantow, DTRATDTON

Kevin Cabble, ERD, NNSANSO

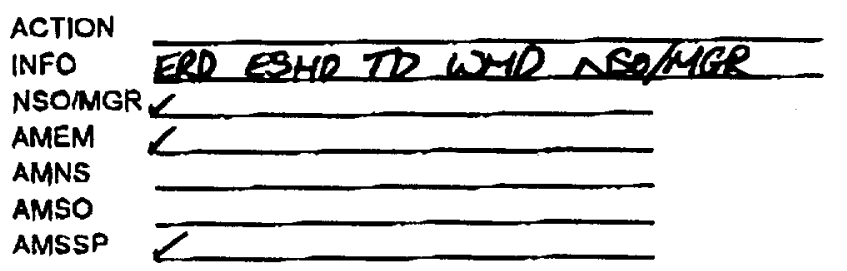




\section{Distribution}

*Provide copy in initial distribution of Revision 0 and subsequent revisions, if applicable. Copies of the NDEP-approved document will be distributed to others.

\section{$\underline{\text { Copies }}$}

Terre Maize

1 (Controlled)*

State of Nevada

Bureau of Federal Facilities

Division of Environmental Protection

1771 E. Flamingo Rd., Suite 121-A

Las Vegas, NV 89119

Don Elle

State of Nevada

Bureau of Federal Facilities

Division of Environmental Protection

1771 E. Flamingo Rd., Suite 121-A

Las Vegas, NV 89119

Shirley Doty

Environmental Restoration Division

U.S. Department of Energy

National Nuclear Security Administration

Nevada Site Office

P.O. Box 98518, M/S 505

Las Vegas, NV 89193-8518

Janet Appenzeller-Wing

Environmental Restoration Division

U.S. Department of Energy

National Nuclear Security Administration

Nevada Site Office

P.O. Box 98518, M/S 505

Las Vegas, NV 89193-8518
1 (Controlled)*

1 (Controlled)*

1 (Uncontrolled)* 
Karen Beckley

State of Nevada

Bureau of Federal Facilities

Division of Environmental Protection

333 W. Nye Lane, Room 138

Carson City, NV 89706-0851

Kevin Cabble

Environmental Restoration Division

U.S. Department of Energy

National Nuclear Security Administration

Nevada Site Office

P.O. Box 98518, M/S 505

Las Vegas, NV 89193-8518

David Swanson

Assistant Project Manager

Nye County

Department of Natural Resources \& Federal Facilities

1210 E. Basin Road, Ste. \#6

Pahrump, NV 89060

U.S. Air Force

DOE Liaison Officer

P.O. Box 98518, M/S 505

Las Vegas, NV 89193-8518

Eloisa V. Hopper

US Air Force

99 ABW-EM

4349 Duffer Drive, Suite 1601

Nellis Air Force Base, NV 89191-7007

Air Warfare Center

RMO/RMI

3770 Duffer Drive

Nellis Air Force Base, NV 89191-7001

Jeffrey L. Smith

Bechtel Nevada

P.O. Box 98521, M/S NTS306

Las Vegas, NV 89193-8521
1 (Controlled)*

1 (Uncontrolled)*
1 (Uncontrolled)*

1 (Uncontrolled, electronic copy)
1 (Uncontrolled)*

1 (Controlled)*

2 (Uncontrolled)*

1 (Uncontrolled)*

1 (Uncontrolled)* 
Brian Hoenes

Stoller-Navarro

7710 W. Cheyenne Ave., Bldg. 3

Las Vegas, NV 89129

Robert Boehlecke

Stoller-Navarro

7710 W. Cheyenne Ave., Bldg. 3

Las Vegas, NV 89129

Northern Range Commander

Lt. Colonel Scarine

RMO Building 200

3770 Duffer Drive

Nellis Air Force Base, NV 89191-7007

Vern Gabbard

Sandia National Laboratory/TTR

Box 871

Tonopah, NV 89049

FFACO Support Office

Stoller-Navarro

7710 W. Cheyenne Ave., Bldg. 3

Las Vegas, NV 89129

Southern Nevada Public Reading Facility

c/o Nuclear Testing Archive

P.O. Box 98521, M/S 400

Las Vegas, NV 89193-8521

Manager, Northern Nevada FFACO

Public Reading Facility

c/o Nevada State Library \& Archives

Carson City, NV 89701-4285

U.S. Department of Energy

Office of Scientific and Technical Information

P.O. Box 62

Oak Ridge, TN 37831-0062
1 (Uncontrolled)

2 (Uncontrolled)*

1 (Uncontrolled)*

1 (Uncontrollled)*

1 (Controlled)

1 (Controlled)

1 (Uncontrolled)

1 (Uncontrolled)

1 (Uncontrolled, electronic copy) 
U.S. Department of Energy

National Nuclear Security Administration

Nevada Site Office

Technical Library

P.O. Box 98518, M/S 505

Las Vegas, NV 89193-8518

Stoller-Navarro

Central Files

7710 W. Cheyenne Ave., Bldg. 3

Las Vegas, NV 89129
1 (Uncontrolled)

\section{1 (Uncontrolled)*}

